\title{
Fifty State Survey of Adult Sex Offender Registration Requirements
}

\section{NIC/WCL Project on Addressing Prison Rape}

\begin{tabular}{|c|c|}
\hline \multicolumn{2}{|r|}{ ALABAMA } \\
\hline $\begin{array}{l}\text { Registrable Offenses } \\
\text { (Alabama) }\end{array}$ & 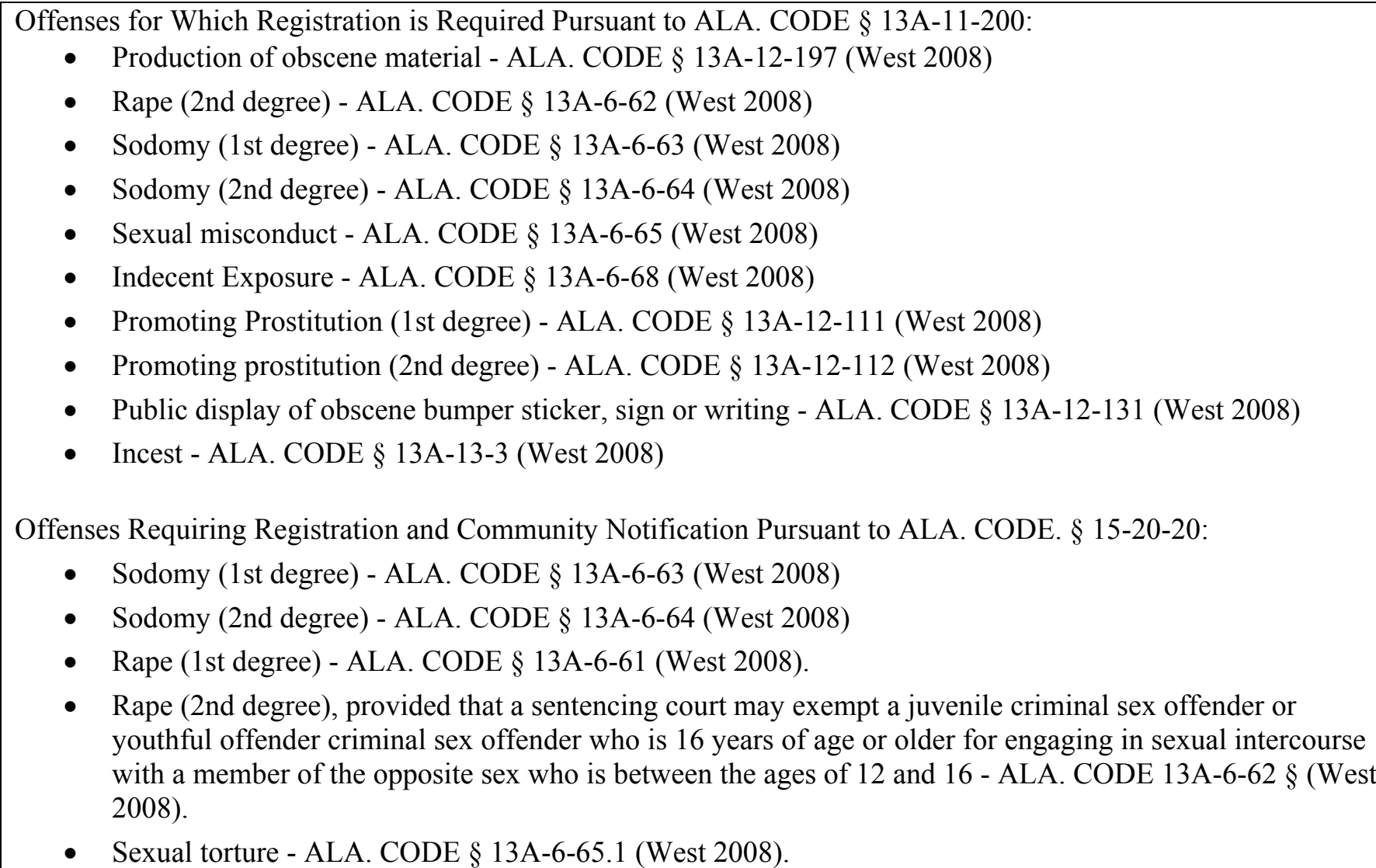 \\
\hline
\end{tabular}

** Denotes those states where sex offender registration is required for convictions under the staff sexual misconduct laws of the states. Staff and inmates could also be required to register as sex offenders if the offense were charged under other registrable offenses.

This publication is developed by the NIC/WCL Project on Addressing Prison Rape under NIC Cooperative Agreement 06S20GJJ1.

This is not to be posted or reproduced without permission from the authors.

American University, Washington College of Law

Current as of August 2009 


\section{Fifty State Survey of Adult Sex Offender Registration Requirements}

\section{NIC/WCL Project on Addressing Prison Rape}

\begin{tabular}{|c|c|}
\hline $\begin{array}{l}\text { Registrable Offenses Cont'd } \\
\text { (Alabama) }\end{array}$ & 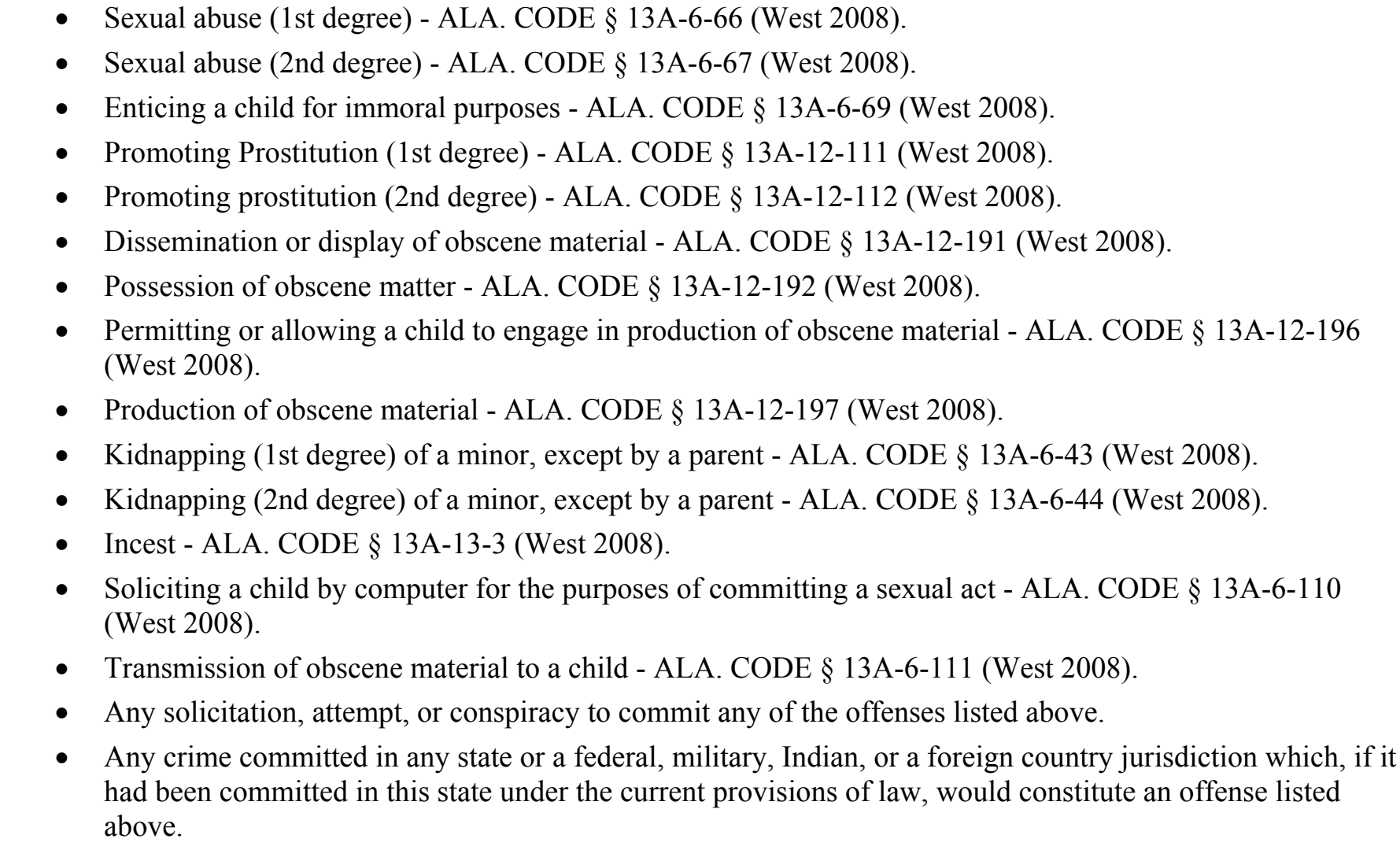 \\
\hline $\begin{array}{l}\text { Sex Offender Registration } \\
\text { Required for Staff Sexual } \\
\text { Misconduct? } \\
\text { (Alabama) }\end{array}$ & NO \\
\hline
\end{tabular}

** Denotes those states where sex offender registration is required for convictions under the staff sexual misconduct laws of the states. Staff and inmates could also be required to register as sex offenders if the offense were charged under other registrable offenses.

This publication is developed by the NIC/WCL Project on Addressing Prison Rape under NIC Cooperative Agreement 06S20GJJ1.

This is not to be posted or reproduced without permission from the authors.

American University, Washington College of Law

Current as of August 2009 


\section{Fifty State Survey of Adult Sex Offender Registration Requirements}

\section{NIC/WCL Project on Addressing Prison Rape}

\begin{tabular}{|c|c|}
\hline $\begin{array}{l}\text { Information Maintained in } \\
\text { Sex Offender Registry } \\
\text { (Alabama) }\end{array}$ & $\begin{array}{l}\text { ALA. CODE } § 15-20-21 \text { (West 2008) } \\
\text { (3) Community notification flyer. This notification shall include the following information on the criminal sex } \\
\text { offender: } \\
\text { - name } \\
\text { - sex } \\
\text { - complete physical description } \\
\text { - address of residence } \\
\text { - address of employer (if any) } \\
\text { - address where offender attends school (if applicable) } \\
\text { - sex offense history including statement of criminal sex offense for which offender was convicted } \\
\text { - age of the offender's victim } \\
\text { - geographic area where sex offense occurred } \\
\text { - date upon which the offender will be released } \\
\text { - fingerprints } \\
\text { - photograph }\end{array}$ \\
\hline $\begin{array}{l}\text { Community Notification } \\
\text { and Websites } \\
\text { (Alabama) }\end{array}$ & $\begin{array}{l}\text { ALA. CODE } \$ 15-20-25 \text { (West 2008) } \\
\text { (b): } \\
\text { - A community notification flyer shall be made by regular mail or hand delivered to all legal residences required } \\
\text { by this section. } \\
\text { - In addition, any other method reasonably expected to provide notification may be utilized, including, but not } \\
\text { limited to: } \\
\text { o posting a copy of the notice in a prominent place at the office of the sheriff and at the police station closest } \\
\text { to the declared residence of the released criminal sex offender, } \\
\text { o publicizing the notice in a local newspaper, or }\end{array}$ \\
\hline
\end{tabular}

** Denotes those states where sex offender registration is required for convictions under the staff sexual misconduct laws of the states. Staff and inmates could also be required to register as sex offenders if the offense were charged under other registrable offenses.

This publication is developed by the NIC/WCL Project on Addressing Prison Rape under NIC Cooperative Agreement 06S20GJJ1.

This is not to be posted or reproduced without permission from the authors.

American University, Washington College of Law

Current as of August 2009 


\section{Fifty State Survey of Adult Sex Offender Registration Requirements}

\section{NIC/WCL Project on Addressing Prison Rape}

\begin{tabular}{|c|c|}
\hline $\begin{array}{l}\text { Limitations on Residency } \\
\text { or Employment } \\
\text { (Alabama) }\end{array}$ & $\begin{array}{l}\text { ALA. CODE } § 15-20-26 \text { (West 2008) } \\
\text { (a): Adult criminal sex offenders may not live or work within } 2000 \text { feet of a school or child care facility. } \\
\text { (b): Sex offenders may not live where a minor resides unless the offender is the parent, grandparent or stepparent of } \\
\text { the minor. } \\
\text { (c): Adult criminal sex offenders may not live with minor if: } \\
\text { - the offender's parental rights have been terminated } \\
\text { - the minor child was the victim of the offender, or } \\
\text { - the offender has ever been convicted of a criminal sex offense involving a child } \\
\text { (d): No adult criminal sex offender shall willfully or knowingly come within } 100 \text { feet of any of his or her former } \\
\text { victims, except as elsewhere provided by law, or make any visual or audible sexually suggestive or obscene gesture, } \\
\text { sound, or communication at or to a former victim or a member of the victim's immediate family. } \\
\text { (f): No child sex offender may loiter or work within } 500 \text { feet of a school, child care facility, playground, athletic } \\
\text { field or facility for educating minors. }\end{array}$ \\
\hline $\begin{array}{l}\text { Duration of Registration } \\
\text { (Alabama) }\end{array}$ & $\begin{array}{l}\text { ALA. CODE } § 15-20-33 \text { (West 2008) } \\
\text { (a) Adult criminal sex offenders are subject to registration and notification for life. }\end{array}$ \\
\hline & ALASKA** \\
\hline $\begin{array}{l}\text { Registrable Offenses } \\
\text { (Alaska) }\end{array}$ & $\begin{array}{l}\text { - } 1 \text { st degree murder during commission or attempted commission of a sexual offense or kidnapping of a child } \\
\text { under the age of } 16 \text { - ALASKA STAT. } \$ 11.41 .100(\mathrm{a})(3) \text { (West 2008). } \\
\text { - } 2 \text { nd degree murder during commission of sexual assault in } 1 \text { st or } 2 \text { nd degree or the sexual abuse of a minor }\end{array}$ \\
\hline
\end{tabular}

** Denotes those states where sex offender registration is required for convictions under the staff sexual misconduct laws of the states. Staff and inmates could also be required to register as sex offenders if the offense were charged under other registrable offenses.

This publication is developed by the NIC/WCL Project on Addressing Prison Rape under NIC Cooperative Agreement 06S20GJJ1.

This is not to be posted or reproduced without permission from the authors.

American University, Washington College of Law

Current as of August 2009 


\section{Fifty State Survey of Adult Sex Offender Registration Requirements}

\section{NIC/WCL Project on Addressing Prison Rape}

\begin{tabular}{|c|c|}
\hline $\begin{array}{l}\text { Registrable Offenses Cont'd } \\
\text { (Alaska) }\end{array}$ & 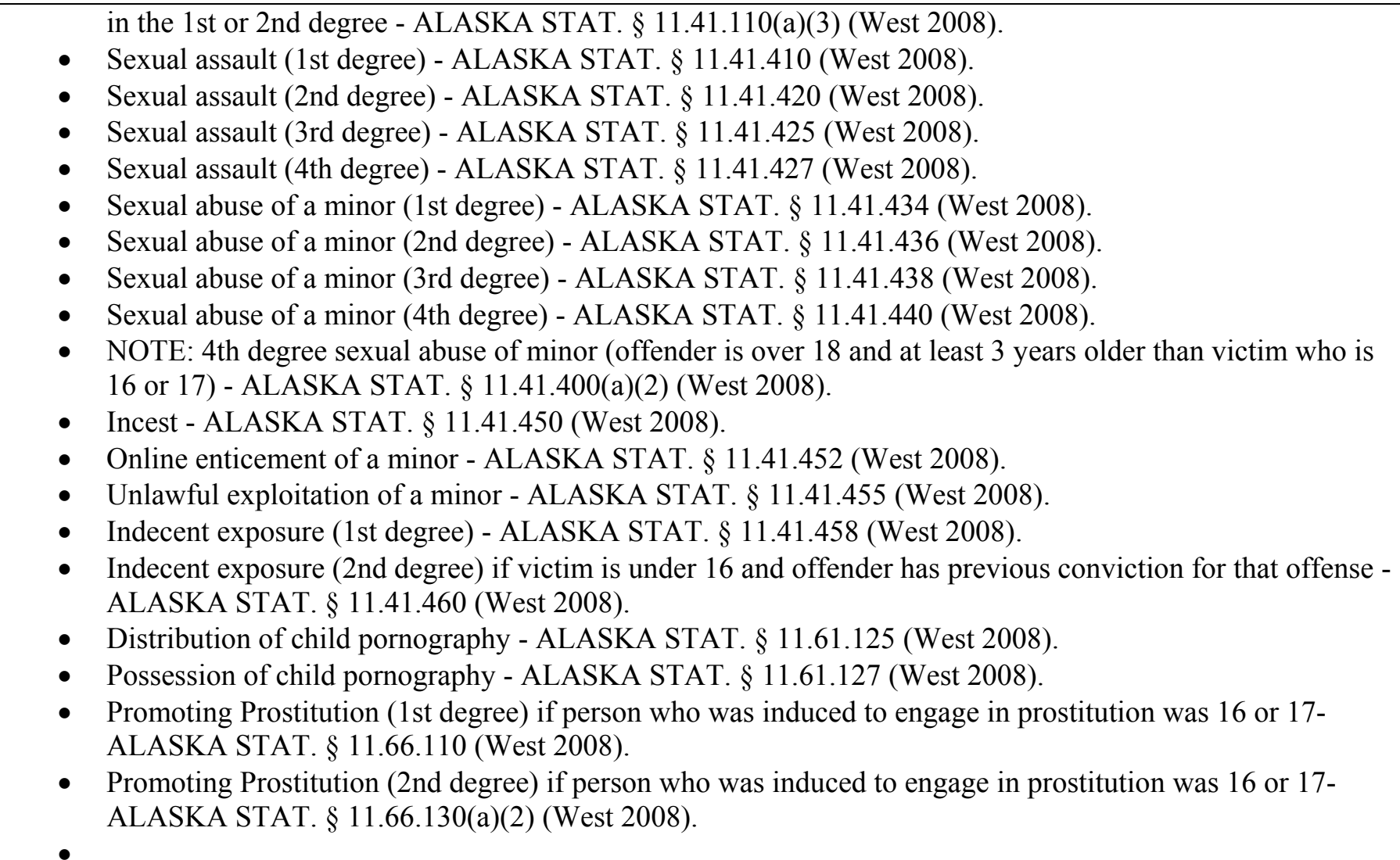 \\
\hline $\begin{array}{l}\text { Sex Offender Registration } \\
\text { Required for Staff Sexual } \\
\text { Misconduct? } \\
\text { (Alaska) }\end{array}$ & $\begin{array}{l}\text { YES. } \\
\text { ALASKA STAT. } \$ 11.41 .410 \text { (West 2008). } \\
\text { Sexual assault in the first degree. }\end{array}$ \\
\hline
\end{tabular}

** Denotes those states where sex offender registration is required for convictions under the staff sexual misconduct laws of the states. Staff and inmates could also be required to register as sex offenders if the offense were charged under other registrable offenses.

This publication is developed by the NIC/WCL Project on Addressing Prison Rape under NIC Cooperative Agreement 06S20GJJ1.

This is not to be posted or reproduced without permission from the authors.

American University, Washington College of Law

Current as of August 2009 


\section{Fifty State Survey of Adult Sex Offender Registration Requirements}

\section{NIC/WCL Project on Addressing Prison Rape}

\begin{tabular}{|c|c|}
\hline $\begin{array}{l}\text { Sex Offender Registration } \\
\text { Required for Staff Sexual } \\
\text { Misconduct? Cont'd } \\
\text { (Alaska) }\end{array}$ & $\begin{array}{l}\text { (a) An offender commits the crime of sexual assault in the first degree if } \\
\text { (1) the offender engages in sexual penetration with another person without consent of that person; } \\
\text { (2) the offender attempts to engage in sexual penetration with another person without consent of that person } \\
\text { and causes serious physical injury to that person; } \\
\text { (3) the offender engages in sexual penetration with another person } \\
\text { (A) who the offender knows is mentally incapable; and } \\
\text { (B) who is in the offender's care } \\
\text { (i) by authority of law; or } \\
\text { (ii) in a facility or program that is required by law to be licensed by the state; or } \\
\text { (4) the offender engages in sexual penetration with a person who the offender knows is unaware that a } \\
\text { sexual act is being committed and } \\
\text { (A) the offender is a health care worker; and } \\
\text { (B) the offense takes place during the course of professional treatment of the victim. } \\
\text { (b) Sexual assault in the first degree is an unclassified felony and is punishable as provided in AS } 12.55 \text {. } \\
\text { ALASKA STAT. § } 11.41 .420 \text { (West } 2008 \text { ). } \\
\text { Sexual assault in the second degree. } \\
\text { (a) An offender commits the crime of sexual assault in the second degree if } \\
\text { (1) the offender engages in sexual contact with another person without consent of that person; } \\
\text { (2) the offender engages in sexual contact with a person } \\
\text { (A) who the offender knows is mentally incapable; and } \\
\text { (B) who is in the offender's care } \\
\text { (i) by authority of law; or } \\
\text { (ii) in a facility or program that is required by law to be licensed by the state; }\end{array}$ \\
\hline
\end{tabular}

** Denotes those states where sex offender registration is required for convictions under the staff sexual misconduct laws of the states. Staff and inmates could also be required to register as sex offenders if the offense were charged under other registrable offenses.

This publication is developed by the NIC/WCL Project on Addressing Prison Rape under NIC Cooperative Agreement 06S20GJJ1.

This is not to be posted or reproduced without permission from the authors.

American University, Washington College of Law

Current as of August 2009 


\section{Fifty State Survey of Adult Sex Offender Registration Requirements}

\section{NIC/WCL Project on Addressing Prison Rape}

\begin{tabular}{|c|c|}
\hline $\begin{array}{l}\text { Sex Offender Registration } \\
\text { Required for Staff Sexual } \\
\text { Misconduct? Cont'd } \\
\text { (Alaska) }\end{array}$ & 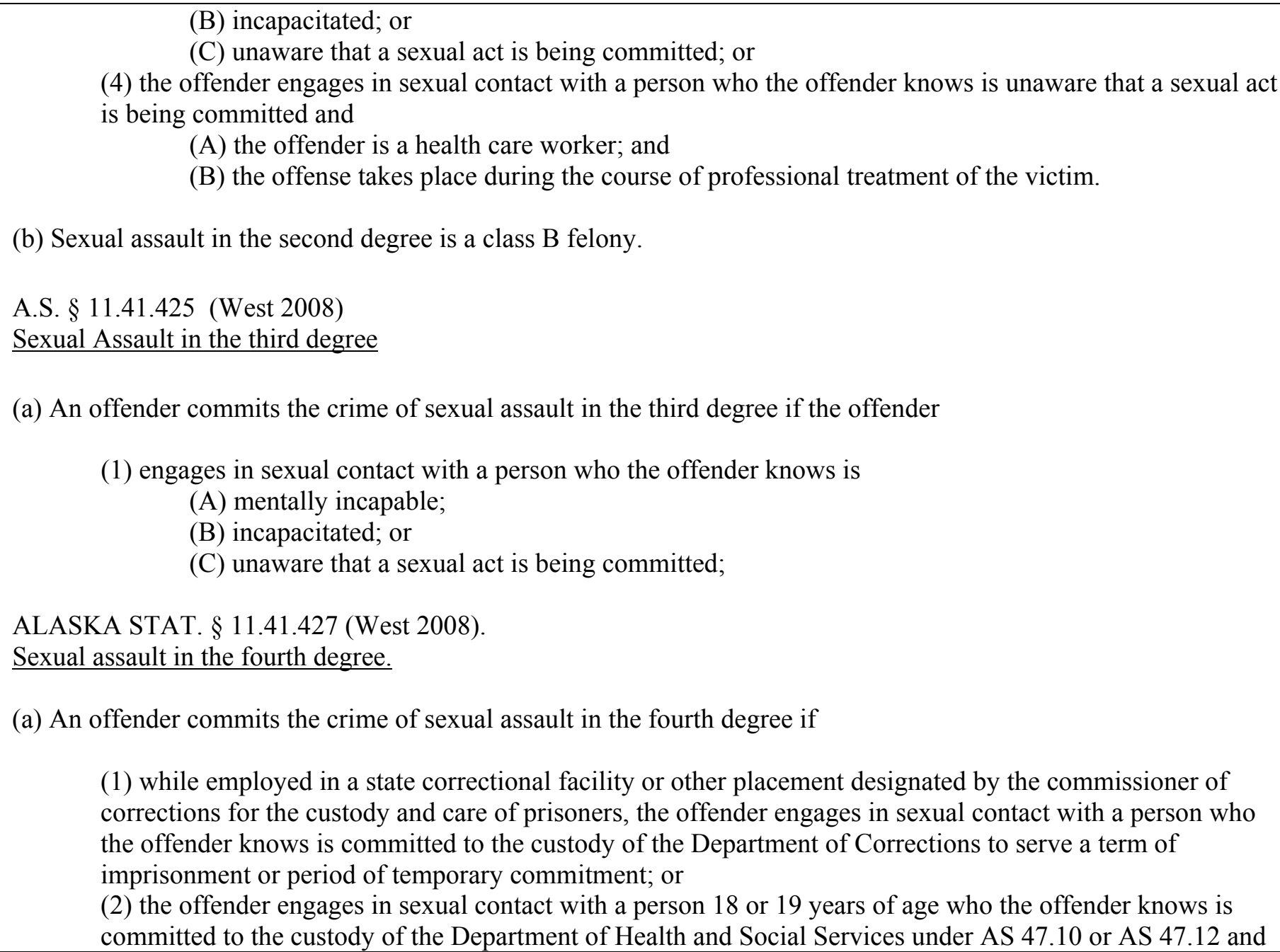 \\
\hline
\end{tabular}

** Denotes those states where sex offender registration is required for convictions under the staff sexual misconduct laws of the states. Staff and inmates could also be required to register as sex offenders if the offense were charged under other registrable offenses.

This publication is developed by the NIC/WCL Project on Addressing Prison Rape under NIC Cooperative Agreement 06S20GJJ1.

This is not to be posted or reproduced without permission from the authors.

American University, Washington College of Law

Current as of August 2009 


\section{Fifty State Survey of Adult Sex Offender Registration Requirements}

\section{NIC/WCL Project on Addressing Prison Rape}

\begin{tabular}{|c|c|}
\hline $\begin{array}{l}\text { Sex Offender Registration } \\
\text { Required for Staff Sexual } \\
\text { Misconduct? Cont'd } \\
\text { (Alaska) }\end{array}$ & $\begin{array}{l}\text { the offender is the legal guardian of the person. } \\
\text { (b) Sexual assault in the fourth degree is a class A misdemeanor. }\end{array}$ \\
\hline $\begin{array}{l}\text { Information Maintained in } \\
\text { Sex Offender Registry } \\
\text { (Alaska) }\end{array}$ & $\begin{array}{l}\text { A.S. } \$ 12.63 .010(\text { b) (West 2008). } \\
\text { (b)(1)(A) Name, address, place of employment, and date of birth } \\
\text { (B) each conviction for a sex offense or child kidnapping for which the duty to register has not terminated } \\
\text { under AS } 12.63 .020 \text {, the date of the sex offense or child kidnapping convictions, the place and court of the } \\
\text { sex offense or child kidnapping convictions, and whether the sex offender or child kidnapper has been } \\
\text { unconditionally discharged from the conviction for a sex offense or child kidnapping and the date of the } \\
\text { unconditional discharge; if the sex offender or child kidnapper asserts that the offender or kidnapper has } \\
\text { been unconditionally discharged, the offender or kidnapper shall supply proof of that discharge acceptable } \\
\text { to the department; } \\
\text { (C) all aliases used; } \\
\text { (D) the sex offender's or child kidnapper's driver's license number; } \\
\text { (E) the description, license numbers, and vehicle identification numbers of motor vehicles the sex offender or } \\
\text { child kidnapper has access to, regardless of whether that access is regular or not; } \\
\text { (F) any identifying features of the sex offender or child kidnapper; } \\
\text { (G) anticipated changes of address; } \\
\text { (H) a statement concerning whether the offender or kidnapper has had treatment for a mental abnormality or } \\
\text { personality disorder since the date of conviction for an offense requiring registration under this chapter; } \\
\text { and } \\
\text { (I) each electronic mail address, instant messaging address, and other Internet communication identifier used } \\
\text { by the sex offender or child kidnapper; }\end{array}$ \\
\hline
\end{tabular}

** Denotes those states where sex offender registration is required for convictions under the staff sexual misconduct laws of the states. Staff and inmates could also be required to register as sex offenders if the offense were charged under other registrable offenses.

This publication is developed by the NIC/WCL Project on Addressing Prison Rape under NIC Cooperative Agreement 06S20GJJ1.

This is not to be posted or reproduced without permission from the authors.

American University, Washington College of Law

Current as of August 2009 


\section{Fifty State Survey of Adult Sex Offender Registration Requirements}

\section{NIC/WCL Project on Addressing Prison Rape}

\begin{tabular}{|c|c|}
\hline $\begin{array}{l}\text { Community Notification } \\
\text { and Websites } \\
\text { (Alaska) }\end{array}$ & $\begin{array}{l}\text { A.S. } \S 18.65 .087 \text { (West 2008). } \\
\text { (h): } \\
\text { - The Department of Public Safety shall provide on the Internet website that the department maintains for the } \\
\text { central registry of sex offenders and child kidnappers information as to how members of the public using the } \\
\text { website may access or compile the information relating to sex offenders or child kidnappers for a particular } \\
\text { geographic area on a map. } \\
\text { - The information may direct members to mapping programs available on the Internet and to Internet websites } \\
\text { where information contained in the registry has already been converted to a map or geographic format. }\end{array}$ \\
\hline $\begin{array}{l}\text { Limitations on Residency } \\
\text { or Employment } \\
\text { (Alaska) }\end{array}$ & None. \\
\hline $\begin{array}{l}\text { Duration of Registration } \\
\text { (Alaska) }\end{array}$ & $\begin{array}{l}\text { A.S. } § 12.63 .020 \text { (West 2008). } \\
\text { (a)(1): Life for offenders convicted of: } \\
\text { •an aggravated sex offense } \\
\text { •two or more sex offenses (including two or more convictions for indecent exposure before a person under the } \\
\text { age of 16) } \\
\text { - two or more child kidnappings, or } \\
\text { • one sex offense and one child kidnapping } \\
\text { (a)(2): } 15 \text { years for offenders convicted for a non-aggravated sex offense or a single child sex offense. } \\
\text { (a)(2)(c): Indefinitely for a sex offender who has not supplied proof of the offender's unconditional discharge for } \\
\text { the sex offense requiring registration. }\end{array}$ \\
\hline
\end{tabular}

** Denotes those states where sex offender registration is required for convictions under the staff sexual misconduct laws of the states. Staff and inmates could also be required to register as sex offenders if the offense were charged under other registrable offenses.

This publication is developed by the NIC/WCL Project on Addressing Prison Rape under NIC Cooperative Agreement 06S20GJJ1.

This is not to be posted or reproduced without permission from the authors.

American University, Washington College of Law

Current as of August 2009 


\section{Fifty State Survey of Adult Sex Offender Registration Requirements}

\section{NIC/WCL Project on Addressing Prison Rape}

\begin{tabular}{|c|c|}
\hline & ARIZONA \\
\hline $\begin{array}{l}\text { Registrable Offenses } \\
\text { (Arizona) }\end{array}$ & 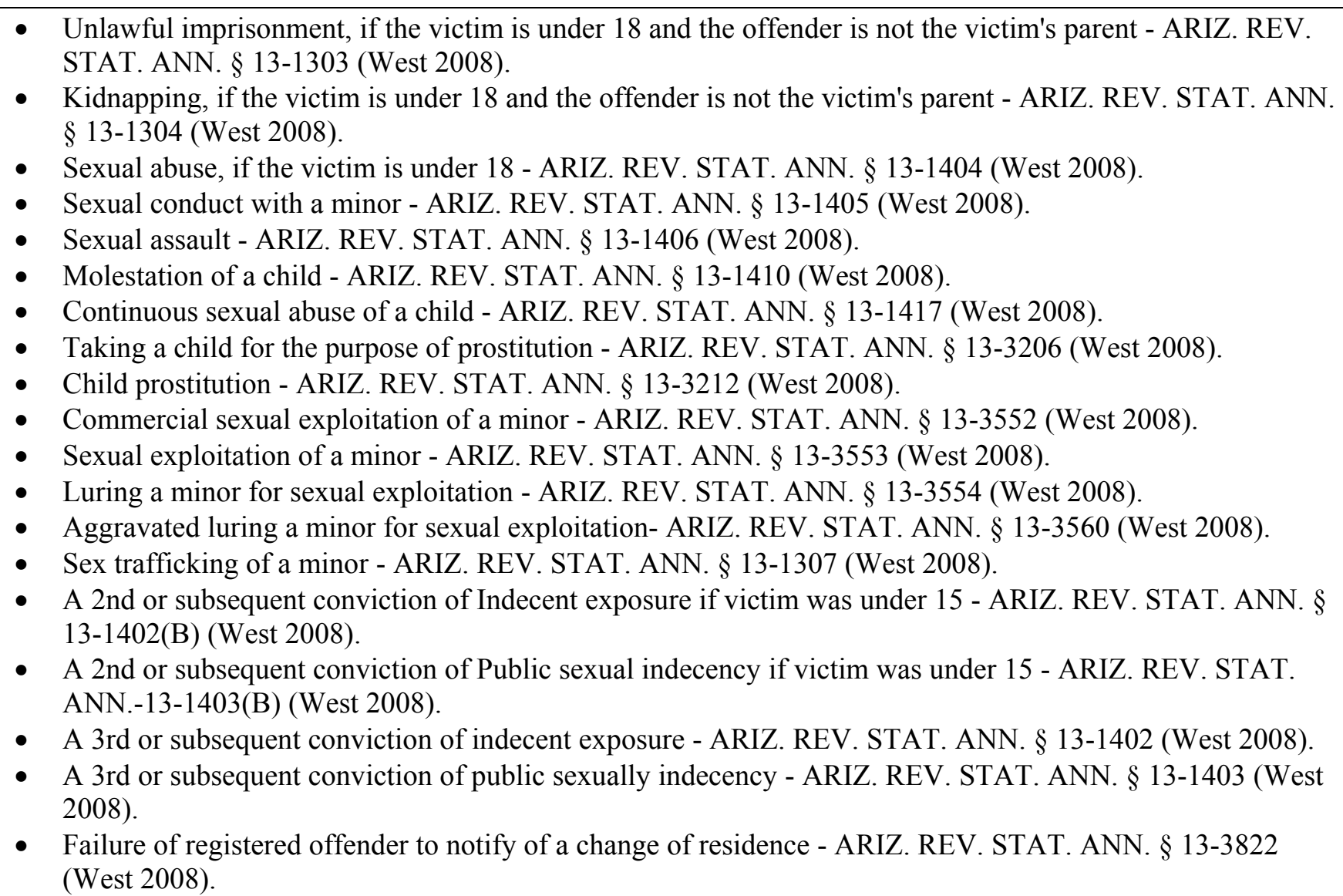 \\
\hline
\end{tabular}

** Denotes those states where sex offender registration is required for convictions under the staff sexual misconduct laws of the states. Staff and inmates could also be required to register as sex offenders if the offense were charged under other registrable offenses.

This publication is developed by the NIC/WCL Project on Addressing Prison Rape under NIC Cooperative Agreement 06S20GJJ1.

This is not to be posted or reproduced without permission from the authors.

American University, Washington College of Law

Current as of August 2009 


\section{Fifty State Survey of Adult Sex Offender Registration Requirements}

\section{NIC/WCL Project on Addressing Prison Rape}

\begin{tabular}{|c|c|}
\hline $\begin{array}{l}\text { Registrable Offenses Cont'd } \\
\text { (Arizona) }\end{array}$ & $\begin{array}{l}\text { - Failure of a person subject to registration to register as a sex offender - ARIZ. REV. STAT. ANN. } \S 13- \\
3824 \text { (West 2008). } \\
\text { In addition, the court may require any person convicted of any sex offense or of child sexual exploitation to register } \\
\text { if there was a finding of sexual motivation }\end{array}$ \\
\hline $\begin{array}{l}\text { Sex Offender Registration } \\
\text { Required for Staff Sexual } \\
\text { Misconduct? } \\
\text { (Arizona) }\end{array}$ & NO \\
\hline $\begin{array}{l}\text { Information Maintained in } \\
\text { Sex Offender Registry } \\
\text { (Arizona) }\end{array}$ & $\begin{array}{l}\text { ARIZ. REV. STAT. } 13 \S 3821 \text { (West 2008). } \\
\text { (H): } \\
\text { - name } \\
\text { - physical location and address of the offender's residence } \\
\text { - name of the owner of the offender's residence } \\
\text { - location and number of any post office boxes used by the offender } \\
\text { - all aliases } \\
\text { - fingerprints } \\
\text { - photograph of offender } \\
\text { - enrollment or employment status at a public or private institution of postsecondary education (if applicable) }\end{array}$ \\
\hline $\begin{array}{l}\text { Community Notification } \\
\text { and Websites } \\
\text { (Arizona) }\end{array}$ & $\begin{array}{l}\text { A.R.S. } 13 \S 3825 \text { (West 2008). } \\
\text { (A): } \\
\text { - Within seventy-two hours after a person who was convicted as a sex offender shall provide all of the following } \\
\text { information to the department of public safety by entering all of the following information into the sex offender } \\
\text { profile and notification database: }\end{array}$ \\
\hline
\end{tabular}

** Denotes those states where sex offender registration is required for convictions under the staff sexual misconduct laws of the states. Staff and inmates could also be required to register as sex offenders if the offense were charged under other registrable offenses.

This publication is developed by the NIC/WCL Project on Addressing Prison Rape under NIC Cooperative Agreement 06S20GJJ1.

This is not to be posted or reproduced without permission from the authors.

American University, Washington College of Law

Current as of August 2009 


\section{Fifty State Survey of Adult Sex Offender Registration Requirements}

\section{NIC/WCL Project on Addressing Prison Rape}

\begin{tabular}{|c|c|}
\hline $\begin{array}{l}\text { Community Notification } \\
\text { and Websites } \\
\text { (Arizona) }\end{array}$ & $\begin{array}{l}\text { o the offender's identifying information. } \\
\text { o a risk assessment of the offender. } \\
\text { o the offender's date of release from confinement or, if the offender is sentenced to probation without jail time, } \\
\text { the date the sentence is imposed. } \\
\text { (B). The information from subsection A is then forwarded to the sheriff in the county where the person is registered. } \\
\text { (C). After receiving the information pursuant to subsection B of this section, the sheriff shall forward the } \\
\text { information to the chief law enforcement officer of the community in which the person resides. } \\
\text { - After reviewing the information received and any other information available to the local law enforcement } \\
\text { agency, the local law enforcement agency shall categorize each offender and place each offender into a } \\
\text { notification level. } \\
\text { - Within forty-five days, the local law enforcement agency shall notify the community of the offender's presence in } \\
\text { the community pursuant to the guidelines established by the community notification guidelines committee. } \\
\text { - If the community does not have a chief law enforcement officer, the sheriff shall perform the duties of the local } \\
\text { law enforcement agency. }\end{array}$ \\
\hline $\begin{array}{l}\text { Limitations on Residency or } \\
\text { Employment } \\
\text { (Arizona) }\end{array}$ & None. \\
\hline $\begin{array}{l}\text { Duration of Registration } \\
\text { (Arizona) }\end{array}$ & $\begin{array}{l}\text { A.R.S. } 13 \S 3821 \text { (West 2008). } \\
\text { (M) } 10 \text { years for persons convicted for a single offense of unlawful imprisonment or kidnapping of a minor. Life for } \\
\text { persons with prior convictions for any registrable offense. }\end{array}$ \\
\hline
\end{tabular}

\section{ARKANSAS**}

** Denotes those states where sex offender registration is required for convictions under the staff sexual misconduct laws of the states. Staff and inmates could also be required to register as sex offenders if the offense were charged under other registrable offenses.

This publication is developed by the NIC/WCL Project on Addressing Prison Rape under NIC Cooperative Agreement 06S20GJJ1.

This is not to be posted or reproduced without permission from the authors.

American University, Washington College of Law

Current as of August 2009 


\section{Fifty State Survey of Adult Sex Offender Registration Requirements}

\section{NIC/WCL Project on Addressing Prison Rape}

\begin{tabular}{|c|c|}
\hline $\begin{array}{l}\text { Registrable Offenses } \\
\text { (Arkansas) }\end{array}$ & 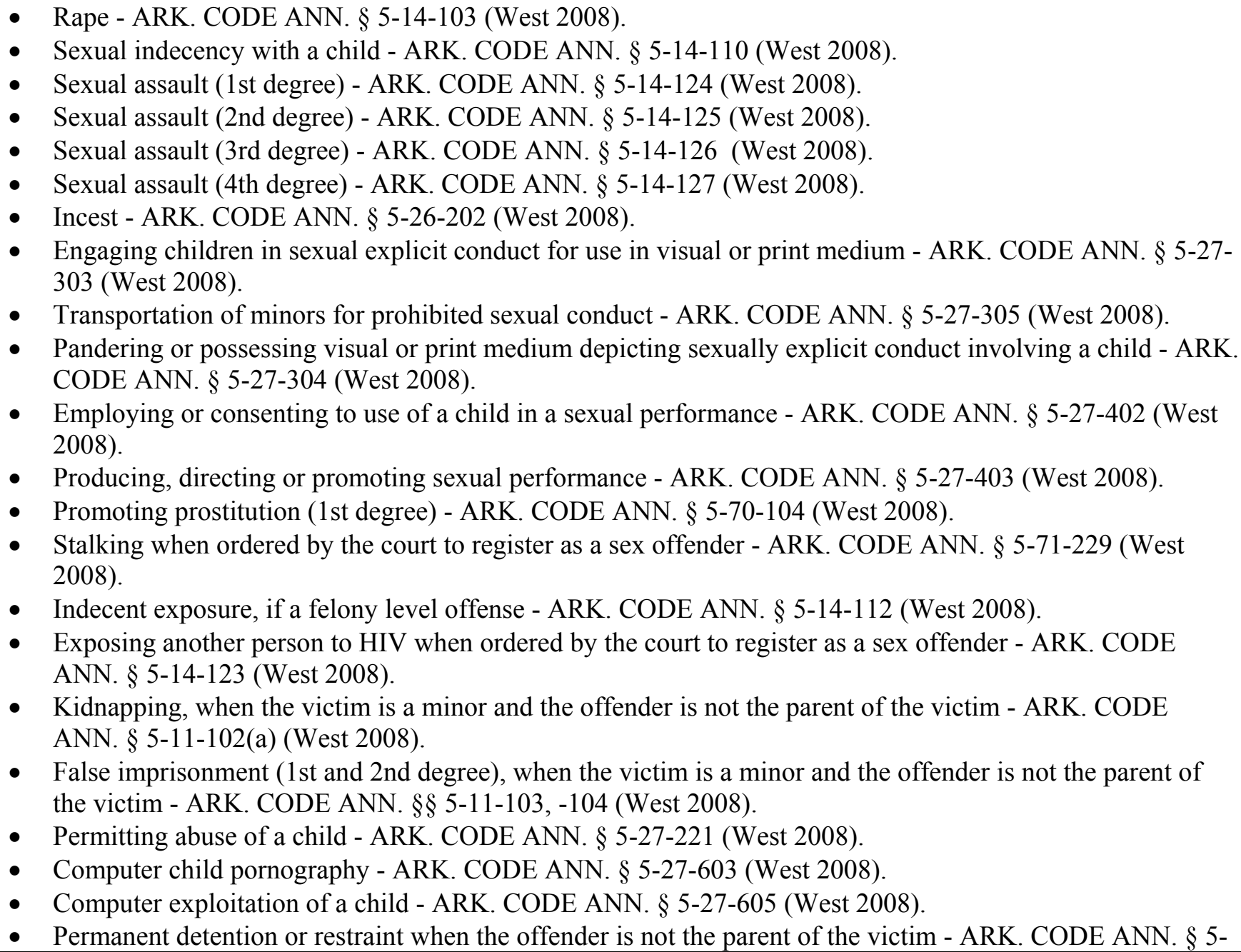 \\
\hline
\end{tabular}

** Denotes those states where sex offender registration is required for convictions under the staff sexual misconduct laws of the states. Staff and 13 inmates could also be required to register as sex offenders if the offense were charged under other registrable offenses.

This publication is developed by the NIC/WCL Project on Addressing Prison Rape under NIC Cooperative Agreement 06S20GJJ1.

This is not to be posted or reproduced without permission from the authors.

American University, Washington College of Law

Current as of August 2009 


\section{Fifty State Survey of Adult Sex Offender Registration Requirements}

\section{NIC/WCL Project on Addressing Prison Rape}

\begin{tabular}{|c|c|}
\hline $\begin{array}{l}\text { Registrable Offenses Cont'd } \\
\text { (Arkansas) }\end{array}$ & $\begin{array}{l}\text { 11-106 (West 2008). } \\
\text { - Distributing, possessing or viewing matter depicting sexually explicit conduct involving a child - ARK. } \\
\text { CODE ANN. } \S 5-27-602 \text { (West 2008). } \\
\text { - The attempt, solicitation or conspiracy to commit any of the offenses enumerated }\end{array}$ \\
\hline $\begin{array}{l}\text { Sex Offender Registration } \\
\text { Required for Staff Sexual } \\
\text { Misconduct? } \\
\text { (Arkansas) }\end{array}$ & $\begin{array}{l}\text { YES. } \\
\text { Staff Members, in their professional capacity, who are convicted of sexual assault in the first, second or third degree } \\
\text { are required to register as sex offenders. } \\
\text { A.C.A. } \S 5-14-124 \text { (West } 2008 \text { ) } \\
\text { Sexual assault in the first degree. } \\
\text { (a) A person commits sexual assault in the first degree if the person engages in sexual intercourse or deviate sexual } \\
\text { activity with another person who is less than eighteen (18) years of age and is not the actor's spouse and the actor is: } \\
\text { (1) Employed with the Department of Correction, the Department of Community Correction, the } \\
\text { Department of Health and Human Services, or any city or county jail or a juvenile detention facility, and the } \\
\text { victim is in the custody of the Department of Correction, the Department of Community Correction, the } \\
\text { Department of Health and Human Services, any city or county jail or juvenile detention facility, or their } \\
\text { contractors or agents; } \\
\text { (2) A professional under } \S 12-12-507(b) \text { and is in a position of trust or authority over the victim and uses the } \\
\text { position of trust or authority to engage in sexual intercourse or deviate sexual activity; or } \\
\text { (3) An employee in the victim's school or school district, a temporary caretaker, or a person in a position of } \\
\text { trust or authority over the victim. } \\
\text { (b) It is no defense to a prosecution under this section that the victim consented to the conduct. } \\
\text { (c) It is an affirmative defense to a prosecution under subdivision (a)(3) of this section that the actor was not more } \\
\text { than three ( } 3 \text { ) years older than the victim. }\end{array}$ \\
\hline
\end{tabular}

** Denotes those states where sex offender registration is required for convictions under the staff sexual misconduct laws of the states. Staff and inmates could also be required to register as sex offenders if the offense were charged under other registrable offenses.

This publication is developed by the NIC/WCL Project on Addressing Prison Rape under NIC Cooperative Agreement 06S20GJJ1.

This is not to be posted or reproduced without permission from the authors.

American University, Washington College of Law

Current as of August 2009 


\section{Fifty State Survey of Adult Sex Offender Registration Requirements}

\section{NIC/WCL Project on Addressing Prison Rape}

\begin{tabular}{|c|c|}
\hline $\begin{array}{l}\text { Sex Offender Registration } \\
\text { Required for Staff Sexual } \\
\text { Misconduct? Cont'd } \\
\text { (Arkansas) }\end{array}$ & $\begin{array}{l}\text { A.C.A. 5-14-125 (West 2008) } \\
\text { Sexual assault in the second degree } \\
\text { (4)(A) Engages in sexual contact with another person who is less than eighteen (18) years of age and the actor is: } \\
\text { (i) Employed with the Department of Correction, Department of Community Correction, any city or county } \\
\text { jail, or any juvenile detention facility, and the minor is in custody at a facility operated by the agency or } \\
\text { contractor employing the actor; } \\
\text { (ii) A professional under } \S 12-12-507 \text { (b) and is in a position of trust or authority over the minor; or } \\
\text { (iii) The minor's guardian, an employee in the minor's school or school district, a temporary caretaker, or a } \\
\text { person in a position of trust or authority over the minor. } \\
\text { (4)(B) For purposes of subdivision (a)(4)(A) of this section, consent of the minor is not a defense to a prosecution; } \\
\text { (6) Is a teacher in a public school in a grade kindergarten through twelve (K-12) and engages in sexual contact with } \\
\text { another person who is: } \\
\text { (A) A student enrolled in the public school; and } \\
\text { (B) Less than twenty-one (21) years of age. } \\
\text { A.C.A. } \S 5-14-126 \text { (West } 2008 \text { ) } \\
\text { Sexual assault in the third degree } \\
\text { (a) A person commits sexual assault in the third degree if the person: (1) Engages in sexual intercourse or deviate } \\
\text { sexual activity with another person who is not the actor's spouse, and the actor is: } \\
\text { (A) Employed with the Department of Correction, Department of Community Correction, Department of } \\
\text { Human Services, or any city or county jail, and the victim is in the custody of the Department of Correction, } \\
\text { Department of Community Correction, Department of Human Services, or any city or county jail; } \\
\text { (B) Employed or contracted with or otherwise providing services, supplies, or supervision to an agency } \\
\text { maintaining custody of inmates, detainees, or juveniles, and the victim is in the custody of the Department of }\end{array}$ \\
\hline
\end{tabular}

** Denotes those states where sex offender registration is required for convictions under the staff sexual misconduct laws of the states. Staff and inmates could also be required to register as sex offenders if the offense were charged under other registrable offenses.

This publication is developed by the NIC/WCL Project on Addressing Prison Rape under NIC Cooperative Agreement 06S20GJJ1.

This is not to be posted or reproduced without permission from the authors.

American University, Washington College of Law

Current as of August 2009 


\section{Fifty State Survey of Adult Sex Offender Registration Requirements}

\section{NIC/WCL Project on Addressing Prison Rape}

\begin{tabular}{|c|c|}
\hline $\begin{array}{l}\text { Sex Offender Registration } \\
\text { Required for Staff Sexual } \\
\text { Misconduct? Cont'd } \\
\text { (Arkansas) }\end{array}$ & $\begin{array}{l}\text { Correction, Department of Community Correction, Department of Human Services, or any city or county jail; or } \\
\text { (C) A professional under } \S 12-12-507(\text { b) or a member of the clergy and is in a position of trust or authority over } \\
\text { the victim and uses the position of trust or authority to engage in sexual intercourse or deviate sexual activity; }\end{array}$ \\
\hline $\begin{array}{l}\text { Information Maintained in } \\
\text { Sex Offender Registry } \\
\text { (Arkansas) }\end{array}$ & $\begin{array}{l}\text { A.C.A. } \S 12 \text {-12-908 (West 2008) } \\
\text { (b) The registration file required by this subchapter shall include: } \\
\text { (1) The offender's full name and all aliases that the offender has used or under which the offender has } \\
\text { been known; } \\
\text { (2) Date of birth; } \\
\text { (3) Sex; } \\
\text { (4) Race; } \\
\text { (5) Height; } \\
\text { (6) Weight; } \\
\text { (7) Hair and eye color; } \\
\text { (8) Address of any temporary residence; } \\
\text { (9) Anticipated address of legal residence; } \\
\text { (10)Driver's license number or state identification number, if available; } \\
\text { (11) Social security number; } \\
\text { (12)Place of employment, education, or training; } \\
\text { (13)Photograph, if not already obtained; } \\
\text { (14)Fingerprints, if not already obtained; } \\
\text { (15)Date of arrest, arresting agency, offense for which convicted or acquitted, and arrest tracking } \\
\text { number for each adjudication of guilt or acquittal on the grounds of mental disease or defect; } \\
\text { (16)A brief description of the crime or crimes for which registration is required; } \\
\text { (17)The registration status of the offender as a sexually violent predator, aggravated sex offender, or sex } \\
\text { (18)A statement in writing signed by the offender acknowledging that the offender has been advised of }\end{array}$ \\
\hline
\end{tabular}

** Denotes those states where sex offender registration is required for convictions under the staff sexual misconduct laws of the states. Staff and inmates could also be required to register as sex offenders if the offense were charged under other registrable offenses.

This publication is developed by the NIC/WCL Project on Addressing Prison Rape under NIC Cooperative Agreement 06S20GJJ1.

This is not to be posted or reproduced without permission from the authors.

American University, Washington College of Law

Current as of August 2009 


\section{Fifty State Survey of Adult Sex Offender Registration Requirements}

\section{NIC/WCL Project on Addressing Prison Rape}

\begin{tabular}{|c|c|}
\hline $\begin{array}{l}\text { Information Maintained in } \\
\text { Sex Offender Registry } \\
\text { Cont'd } \\
\text { (Arkansas) }\end{array}$ & $\begin{array}{l}\text { the duty to register imposed by this subchapter; and } \\
\text { (19) Any other information that the center deems necessary, including, but not limited to: } \\
\text { (A) Criminal and corrections records; } \\
\text { (B) Nonprivileged personnel records; } \\
\text { (C) Treatment and abuse registry records; and } \\
\text { (D) Evidentiary genetic markers. } \\
\text { (c) Certain information such as social security number, driver's license number, } \\
\text { employer, information that may lead to identification of the victim, and the like } \\
\text { may be excluded from the information that is released during the course of } \\
\text { notification. }\end{array}$ \\
\hline $\begin{array}{l}\text { Community Notification } \\
\text { and Websites } \\
\text { (Arkansas) }\end{array}$ & $\begin{array}{l}\text { A.C.A. } \$ 12-12-913 \text { (West 2008) } \\
\text { (b): In accordance with guidelines promulgated by the Sex Offenders Assessment Committee, local law enforcement } \\
\text { agencies having jurisdiction shall disclose relevant and necessary information regarding sex offenders to the public } \\
\text { when the disclosure of such information is necessary for public protection. }\end{array}$ \\
\hline $\begin{array}{l}\text { Limitations on Residency } \\
\text { or Employment } \\
\text { (Arkansas) }\end{array}$ & $\begin{array}{l}\text { A.C.A. } \$ \text {-14-128 (West 2008) } \\
\text { Registered offender living near school, public park, youth center, or daycare prohibited } \\
\text { (a) It is unlawful for a sex offender who is required to register under the Sex Offender Registration Act of } 1997, \S \\
12-12-901 \text { et seq., and who has been assessed as a Level } 3 \text { or Level } 4 \text { offender to reside within two thousand feet } \\
\left(2,000^{\prime}\right) \text { of the property on which any public or private elementary or secondary school, public park, youth center, or } \\
\text { daycare facility is located. } \\
\text { (b)(1) It is not a violation of this section if the property on which the sex offender resides is owned and occupied by } \\
\text { the sex offender and was purchased prior to the date on which the public or private elementary or secondary school, } \\
\text { public park, youth center, or daycare facility was established. } \\
\text { A.C.A. } \$ 5-14-129 \text { (West 2008) }\end{array}$ \\
\hline
\end{tabular}

** Denotes those states where sex offender registration is required for convictions under the staff sexual misconduct laws of the states. Staff and inmates could also be required to register as sex offenders if the offense were charged under other registrable offenses.

This publication is developed by the NIC/WCL Project on Addressing Prison Rape under NIC Cooperative Agreement 06S20GJJ1.

This is not to be posted or reproduced without permission from the authors.

American University, Washington College of Law

Current as of August 2009 


\section{Fifty State Survey of Adult Sex Offender Registration Requirements}

\section{NIC/WCL Project on Addressing Prison Rape}

\begin{tabular}{|c|c|}
\hline $\begin{array}{l}\text { Limitations on Residency } \\
\text { or Employment Cont'd } \\
\text { (Arkansas) }\end{array}$ & 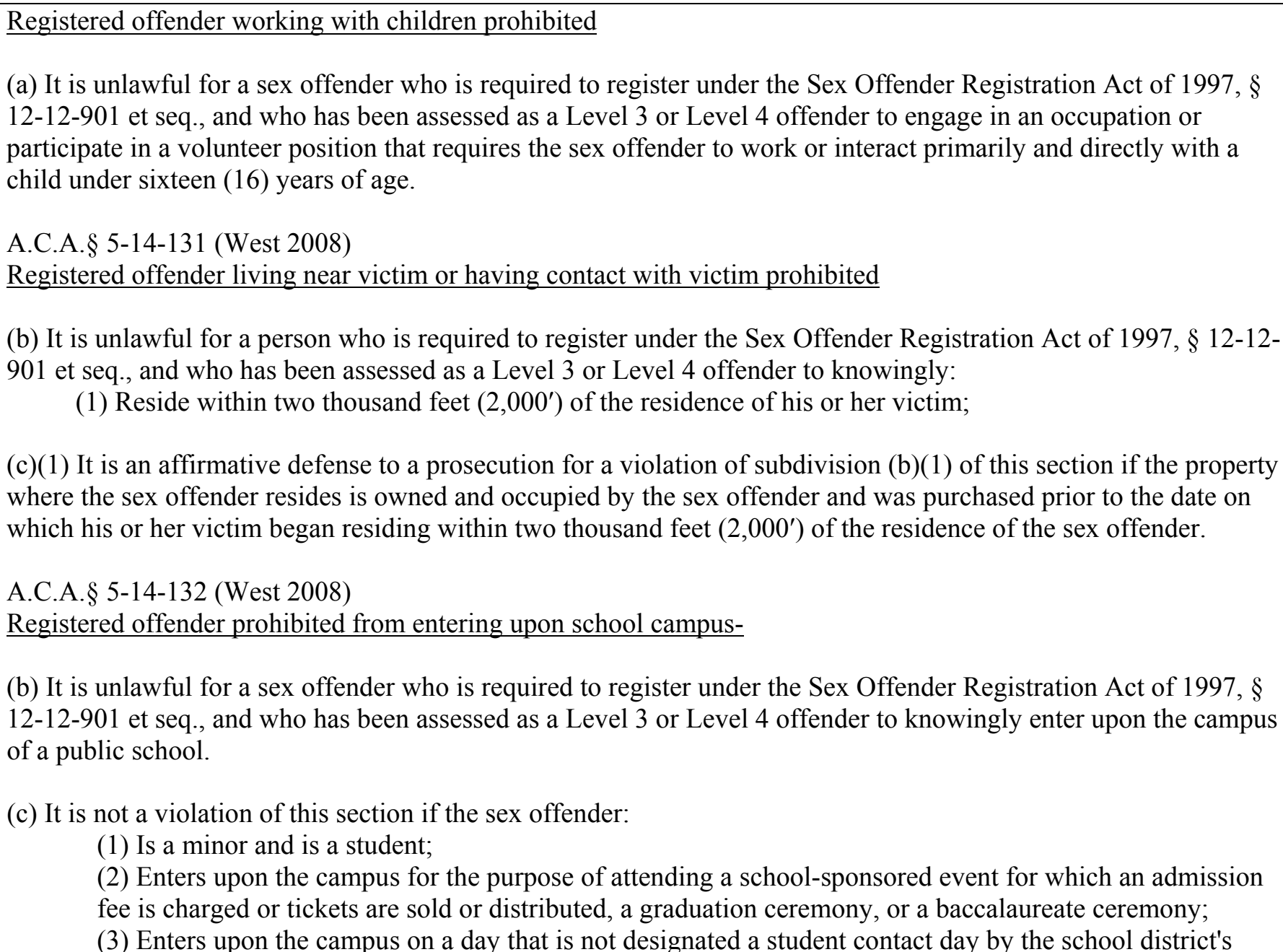 \\
\hline
\end{tabular}

** Denotes those states where sex offender registration is required for convictions under the staff sexual misconduct laws of the states. Staff and inmates could also be required to register as sex offenders if the offense were charged under other registrable offenses.

This publication is developed by the NIC/WCL Project on Addressing Prison Rape under NIC Cooperative Agreement 06S20GJJ1.

This is not to be posted or reproduced without permission from the authors.

American University, Washington College of Law

Current as of August 2009 


\section{Fifty State Survey of Adult Sex Offender Registration Requirements}

\section{NIC/WCL Project on Addressing Prison Rape}

\begin{tabular}{|c|c|}
\hline $\begin{array}{l}\text { Limitations on Residency } \\
\text { or Employment Cont'd } \\
\text { (Arkansas) }\end{array}$ & $\begin{array}{l}\text { calendar or on a day in which no school-sponsored event is taking place upon the campus; or } \\
\text { (4) Is the parent or guardian of a student enrolled in a public school district and enters upon the campus } \\
\text { where the student is enrolled for the purpose of: } \\
\text { (A) Delivering to the student medicine, food, or personal items, provided that the items are } \\
\text { delivered directly to the school office; or } \\
\text { (B) Attending a scheduled parent-teacher conference, provided the sex offender is escorted to and } \\
\text { from the conference by a designated school official or employee. } \\
\text { (d)(1) A sex offender who is the parent or guardian of a child enrolled in a public school district and wishes to enter } \\
\text { upon the campus in which the student is enrolled for any other purpose must give reasonable notice to the school } \\
\text { principal or his or her designee. }\end{array}$ \\
\hline $\begin{array}{l}\text { Duration of Registration } \\
\text { (Arkansas) }\end{array}$ & $\begin{array}{l}\text { A.C.A. } \$ 12-12-919 \text { (West 2008) } \\
\text { (a): Lifetime registration is required for a sex offender: } \\
\text { 1. offenders convicted of an aggravated offense } \\
\text { 2. sexually violent predators, or } \\
\text { 3. offenders adjudicated guilty of a second or subsequent offense under a separate case number, not multiple } \\
\text { counts of the same charge. } \\
\text { (b)(1)(A)(i) Any other sex offender required to register under this subchapter may make application for an order } \\
\text { terminating the obligation to register to the sentencing court fifteen (15) years after release from incarceration or } \\
\text { other institution or fifteen (15) years after having been placed on probation or any other form of community } \\
\text { supervision by the court. } \\
\text { (ii) A sex offender sentenced in another state but permanently residing in Arkansas may make an application } \\
\text { for an order terminating the obligation to register to the court of the county in which the sex offender } \\
\text { resides. } \\
\text { (B)(i) The court shall hold a hearing on the application at which the applicant and any interested persons }\end{array}$ \\
\hline
\end{tabular}

** Denotes those states where sex offender registration is required for convictions under the staff sexual misconduct laws of the states. Staff and inmates could also be required to register as sex offenders if the offense were charged under other registrable offenses.

This publication is developed by the NIC/WCL Project on Addressing Prison Rape under NIC Cooperative Agreement 06S20GJJ1.

This is not to be posted or reproduced without permission from the authors.

American University, Washington College of Law

Current as of August 2009 


\section{Fifty State Survey of Adult Sex Offender Registration Requirements}

\section{NIC/WCL Project on Addressing Prison Rape}

\begin{tabular}{|c|c|}
\hline $\begin{array}{l}\text { Duration of Registration } \\
\text { (Arkansas) }\end{array}$ & $\begin{array}{l}\text { may present witnesses and other evidence. } \\
\text { (ii) No fewer than twenty (20) days prior to the date of the hearing on the application, a copy of the } \\
\text { application for termination of the obligation to register shall be served on the prosecutor of the county in } \\
\text { which the adjudication of guilt triggering registration was obtained. }\end{array}$ \\
\hline & CALIFORNIA ** \\
\hline
\end{tabular}

** Denotes those states where sex offender registration is required for convictions under the staff sexual misconduct laws of the states. Staff and 20 inmates could also be required to register as sex offenders if the offense were charged under other registrable offenses.

This publication is developed by the NIC/WCL Project on Addressing Prison Rape under NIC Cooperative Agreement 06S20GJJ1.

This is not to be posted or reproduced without permission from the authors.

American University, Washington College of Law

Current as of August 2009 


\section{Fifty State Survey of Adult Sex Offender Registration Requirements}

\section{NIC/WCL Project on Addressing Prison Rape}

\begin{tabular}{|c|c|}
\hline $\begin{array}{l}\text { Registrable Offenses Cont'd } \\
\text { (California) }\end{array}$ & 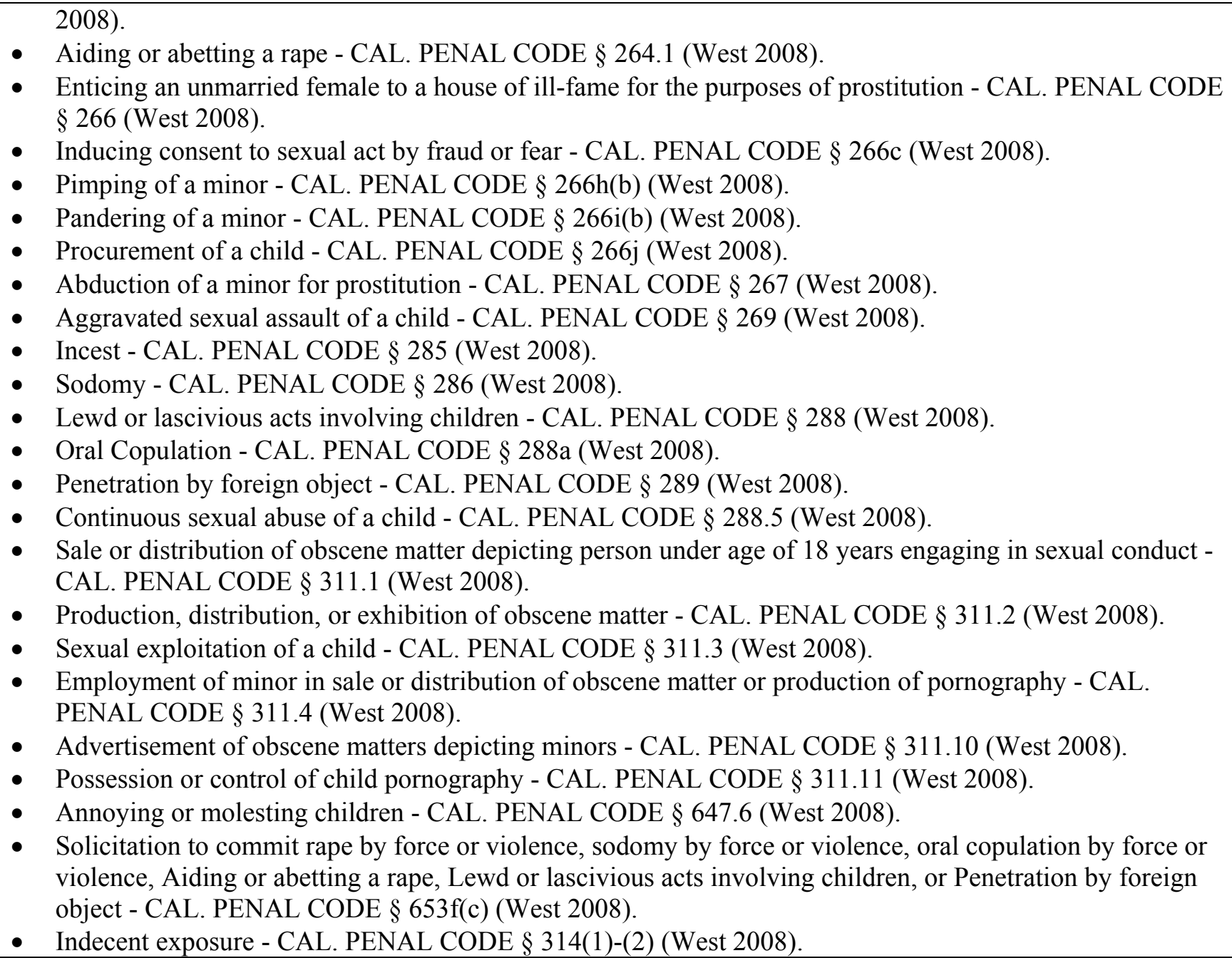 \\
\hline
\end{tabular}

** Denotes those states where sex offender registration is required for convictions under the staff sexual misconduct laws of the states. Staff and inmates could also be required to register as sex offenders if the offense were charged under other registrable offenses.

This publication is developed by the NIC/WCL Project on Addressing Prison Rape under NIC Cooperative Agreement 06S20GJJ1.

This is not to be posted or reproduced without permission from the authors.

American University, Washington College of Law

Current as of August 2009 


\section{Fifty State Survey of Adult Sex Offender Registration Requirements}

\section{NIC/WCL Project on Addressing Prison Rape}

\begin{tabular}{|c|c|}
\hline $\begin{array}{l}\text { Registrable Offenses Cont'd } \\
\text { (California) }\end{array}$ & $\begin{array}{l}\text { - Luring minor under } 14 \text { away from home to commit an offense involving lewd or lascivious conduct - CAL. } \\
\text { PENAL CODE } \S 272 \text { (West 2008). } \\
\text { - Felony violation of sending harmful matter to minor by telephone messages, electronic mail, Internet, or } \\
\text { commercial online service - CAL. PENAL CODE } \S 288.2 \text { (West 2008). } \\
\text { - Conviction for the attempt to commit the offenses above. } \\
\text { - Any person required to register as a sex offender in another state, unless the conviction was for the } \\
\text { equivalent of indecent exposure, unlawful sexual intercourse pursuant to Cal Pen. Code } \S 261.5 \text {, incest, } \\
\text { sodomy, or oral copulation, provided that the offender notifies the Dept. of Justice that the sodomy or oral } \\
\text { copulation was between consenting adults and the Dept. is able to verify that fact. } \\
\text { Any person convicted in any state, federal or military court of any offense that, if committed or attempted } \\
\text { in California, would have been punishable as one or more of the offenses above. }\end{array}$ \\
\hline $\begin{array}{l}\text { Sex Offender Registration } \\
\text { Required for Staff Sexual } \\
\text { Misconduct? } \\
\text { (California) }\end{array}$ & $\begin{array}{l}\text { YES. } \\
\text { An employee or officer of a public detention facility or health care facility who engages in sexual activity- } \\
\text { specifically ) Sodomy, as defined in subdivision (a) of Section } 286 \text {, Oral copulation, as defined in subdivision (a) of } \\
\text { Section } 288 \text { a, Sexual penetration, as defined in subdivision (k) of Section } 289 \text { and is convicted, is required to } \\
\text { register as a sex offender. See, } \S \S 289.6 \& 290 \text {. } \\
\text { Relevant Statutes: } \\
\text { CAL. PENAL } \S 289.6 \text { (West } 2008) \\
\text { (a)(1) An employee or officer or agent of a private person of a public entity health facility or entity that provides a } \\
\text { health facility or staff for a health facility under contract with a public entity, who engages in sexual activity with a } \\
\text { consenting adult who is confined in a health facility is guilty of a public offense. As used in this paragraph, "health } \\
\text { facility" means a health facility as defined in subdivisions (b), (e), (g), (h), and (j), and subparagraph (C) of } \\
\text { paragraph (2) of subdivision (i) of Section } 1250 \text { of the Health and Safety Code, in which the victim has been } \\
\text { confined involuntarily. }\end{array}$ \\
\hline
\end{tabular}

** Denotes those states where sex offender registration is required for convictions under the staff sexual misconduct laws of the states. Staff and inmates could also be required to register as sex offenders if the offense were charged under other registrable offenses.

This publication is developed by the NIC/WCL Project on Addressing Prison Rape under NIC Cooperative Agreement 06S20GJJ1.

This is not to be posted or reproduced without permission from the authors.

American University, Washington College of Law

Current as of August 2009 


\section{Fifty State Survey of Adult Sex Offender Registration Requirements}

\section{NIC/WCL Project on Addressing Prison Rape}

\begin{tabular}{|c|c|}
\hline $\begin{array}{l}\text { Sex Offender Registration } \\
\text { Required for Staff Sexual } \\
\text { Misconduct? Cont'd } \\
\text { (California) }\end{array}$ & 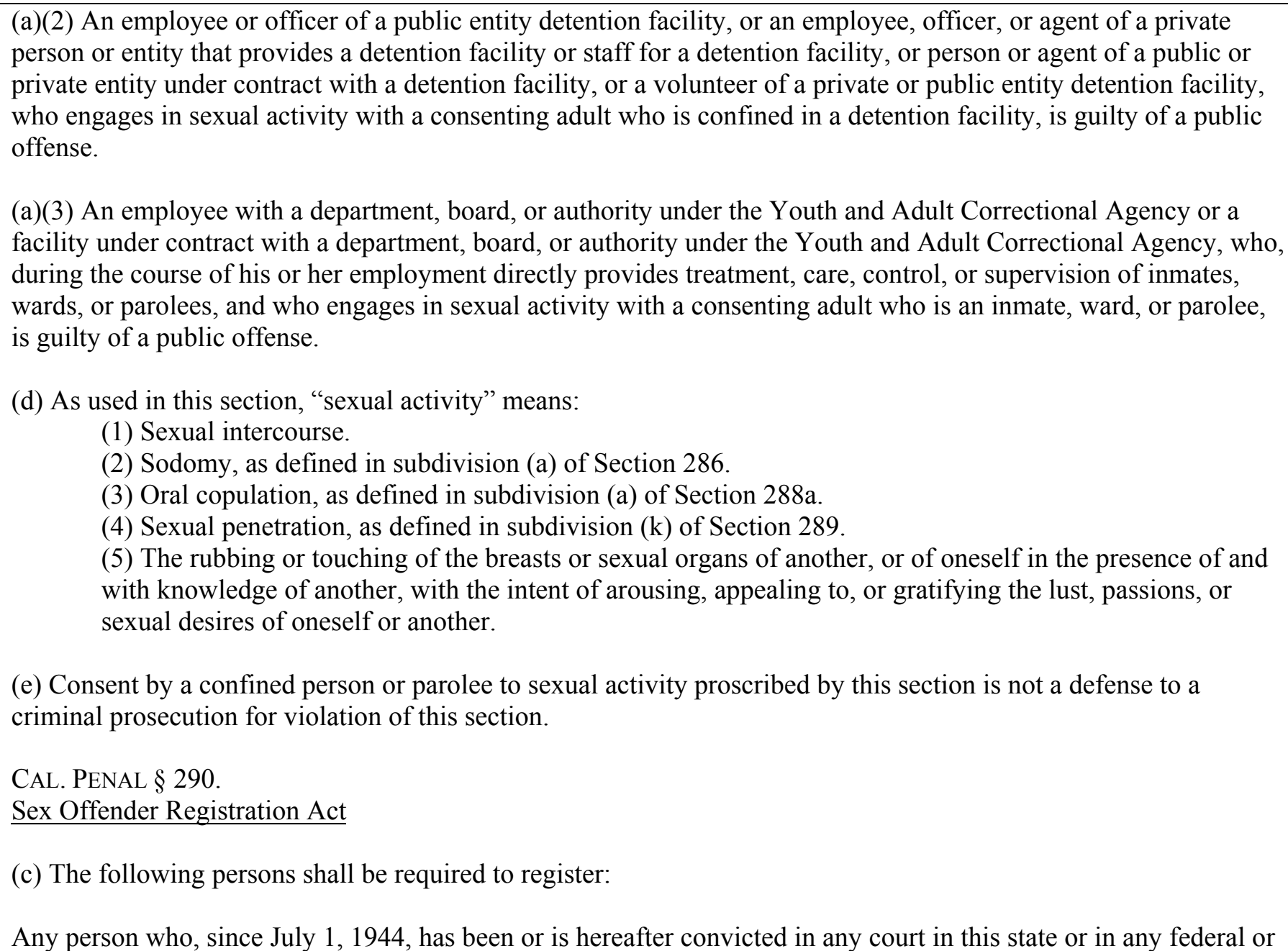 \\
\hline
\end{tabular}

** Denotes those states where sex offender registration is required for convictions under the staff sexual misconduct laws of the states. Staff and inmates could also be required to register as sex offenders if the offense were charged under other registrable offenses.

This publication is developed by the NIC/WCL Project on Addressing Prison Rape under NIC Cooperative Agreement 06S20GJJ1.

This is not to be posted or reproduced without permission from the authors.

American University, Washington College of Law

Current as of August 2009 


\section{Fifty State Survey of Adult Sex Offender Registration Requirements}

\section{NIC/WCL Project on Addressing Prison Rape}

\begin{tabular}{|c|c|}
\hline $\begin{array}{l}\text { Sex Offender Registration } \\
\text { Required for Staff Sexual } \\
\text { Misconduct? Cont'd } \\
\text { (California) }\end{array}$ & $\begin{array}{l}\text { military court of a violation of Section } 187 \text { committed in the perpetration, or an attempt to perpetrate, rape or any } \\
\text { act punishable under Section } 286,288,288 \mathrm{a} \text {, or } 289\end{array}$ \\
\hline $\begin{array}{l}\text { Information Maintained in } \\
\text { Sex Offender Registry } \\
\text { (California) }\end{array}$ & $\begin{array}{l}\text { CAL. PENAL CODE } \$ 290.015 \text { (West 2008) } \\
\text { (a) A person who is subject to the Act shall register, or reregister if the person has previously registered, upon } \\
\text { release from incarceration, placement, commitment, or release on probation pursuant to subdivision (b) of Section } \\
\text { 290. This section shall not apply to a person who is incarcerated for less than } 30 \text { days if he or she has registered as } \\
\text { required by the Act, he or she returns after incarceration to the last registered address, and the annual update of } \\
\text { registration that is required to occur within five working days of his or her birthday, pursuant to subdivision (a) of } \\
\text { Section } 290.012 \text {, did not fall within that incarceration period. The registration shall consist of all of the following: } \\
\text { (1) A statement in writing signed by the person, giving information as shall be required by the Department } \\
\text { of Justice and giving the name and address of the person's employer, and the address of the person's place } \\
\text { of employment if that is different from the employer's main address. } \\
\text { (2) The fingerprints and a current photograph of the person taken by the registering official. } \\
\text { (3) The license plate number of any vehicle owned by, regularly driven by, or registered in the name of the } \\
\text { person. } \\
\text { (4) Notice to the person that, in addition to the requirements of the Act, he or she may have a duty to } \\
\text { register in any other state where he or she may relocate. } \\
\text { (5) Copies of adequate proof of residence, which shall be limited to a California driver's license, California } \\
\text { identification card, recent rent or utility receipt, printed personalized checks or other recent banking } \\
\text { documents showing that person's name and address, or any other information that the registering official } \\
\text { believes is reliable. If the person has no residence and no reasonable expectation of obtaining a residence in } \\
\text { the foreseeable future, the person shall so advise the registering official and shall sign a statement provided } \\
\text { by the registering official stating that fact. Upon presentation of proof of residence to the registering official } \\
\text { or a signed statement that the person has no residence, the person shall be allowed to register. If the person } \\
\text { claims that he or she has a residence but does not have any proof of residence, he or she shall be allowed to }\end{array}$ \\
\hline
\end{tabular}

** Denotes those states where sex offender registration is required for convictions under the staff sexual misconduct laws of the states. Staff and inmates could also be required to register as sex offenders if the offense were charged under other registrable offenses.

This publication is developed by the NIC/WCL Project on Addressing Prison Rape under NIC Cooperative Agreement 06S20GJJ1.

This is not to be posted or reproduced without permission from the authors.

American University, Washington College of Law

Current as of August 2009 


\section{Fifty State Survey of Adult Sex Offender Registration Requirements}

\section{NIC/WCL Project on Addressing Prison Rape}

\begin{tabular}{|c|c|}
\hline $\begin{array}{l}\text { Information Maintained in } \\
\text { Sex Offender Registry } \\
\text { Cont'd } \\
\text { (California) }\end{array}$ & register but shall furnish proof of residence within 30 days of the date he or she is allowed to register. \\
\hline $\begin{array}{l}\text { Community Notification } \\
\text { and Websites } \\
\text { (California) }\end{array}$ & $\begin{array}{l}\text { CAL. PENAL } \S 290.45 \text { (West 2008) } \\
\text { (a)(1): Any designated law enforcement entity may provide information to the public about a person required to } \\
\text { register as a sex offender by whatever means the entity deems appropriate, when necessary to ensure the public } \\
\text { safety based upon information available to the entity concerning that specific person. } \\
\text { CAL. PENAL } \S 290.46 \text { (West 2008) } \\
\text { (a)(1): On or before July } 10,2010 \text {, the Department of Justice shall make available information concerning persons } \\
\text { who are required to register pursuant to Section } 290 \text { to the public via an Internet Web site as specified in this } \\
\text { section. }\end{array}$ \\
\hline $\begin{array}{l}\text { Limitations on Residency or } \\
\text { Employment } \\
\text { (California) }\end{array}$ & $\begin{array}{l}\text { CAL. PENAL } \S 290.95 \text { (West 2008) } \\
\text { (a): Registrants who apply or accept a position that has direct and unaccompanied access to minor children must } \\
\text { disclose their status as a registrant on their application for that position or upon acceptance of the employment. } \\
\text { (b): No registrant who has been convicted of a crime against a victim under the age of } 16 \text { may work in a position } \\
\text { where the registrant would have direct and unaccompanied access to minor children or have supervision or } \\
\text { disciplinary power over minor children. } \\
\text { CAL. PENAL } § 3003.5(\text { b) (West } 2008 \text { ) } \\
\text { Notwithstanding any other provision of law, it is unlawful for any person for whom registration is required pursuant } \\
\text { to Section } 290 \text { to reside within } 2000 \text { feet of any public or private school or park where children regularly gather. }\end{array}$ \\
\hline
\end{tabular}

** Denotes those states where sex offender registration is required for convictions under the staff sexual misconduct laws of the states. Staff and inmates could also be required to register as sex offenders if the offense were charged under other registrable offenses.

This publication is developed by the NIC/WCL Project on Addressing Prison Rape under NIC Cooperative Agreement 06S20GJJ1.

This is not to be posted or reproduced without permission from the authors.

American University, Washington College of Law

Current as of August 2009 


\section{Fifty State Survey of Adult Sex Offender Registration Requirements}

\section{NIC/WCL Project on Addressing Prison Rape}

\begin{tabular}{|c|c|}
\hline $\begin{array}{l}\text { Duration of Registration } \\
\text { (California) }\end{array}$ & $\begin{array}{l}\text { CAL. PENAL } § 290 \text { (West 2008) } \\
\text { (a)(1)(A) Sex offenders must register for life. }\end{array}$ \\
\hline $\begin{array}{l}\text { Registrable Offenses } \\
\text { (Colorado) }\end{array}$ & 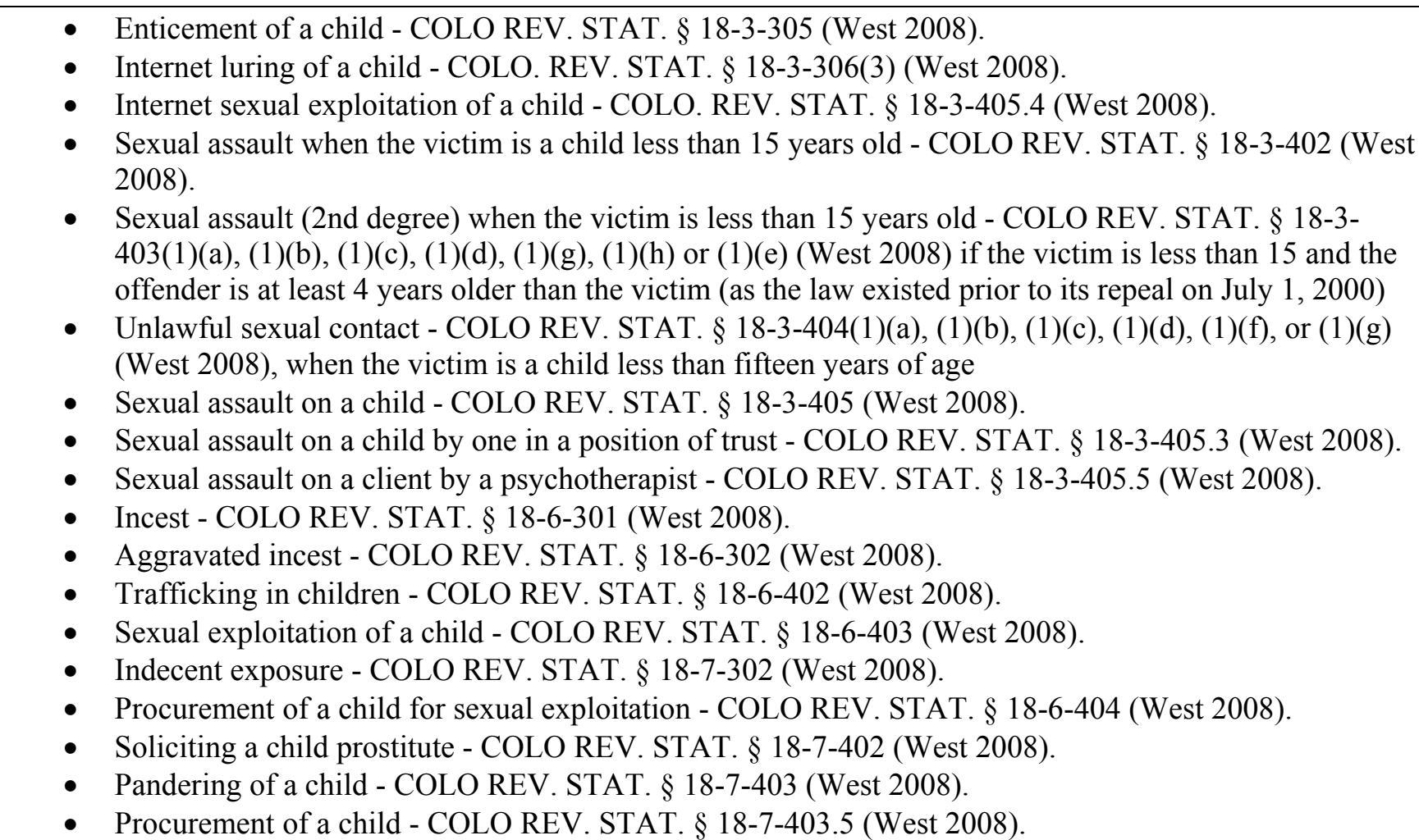 \\
\hline
\end{tabular}

** Denotes those states where sex offender registration is required for convictions under the staff sexual misconduct laws of the states. Staff and inmates could also be required to register as sex offenders if the offense were charged under other registrable offenses.

This publication is developed by the NIC/WCL Project on Addressing Prison Rape under NIC Cooperative Agreement 06S20GJJ1.

This is not to be posted or reproduced without permission from the authors.

American University, Washington College of Law

Current as of August 2009 


\section{Fifty State Survey of Adult Sex Offender Registration Requirements}

\section{NIC/WCL Project on Addressing Prison Rape}

\begin{tabular}{|c|c|}
\hline $\begin{array}{l}\text { Registrable Offenses Cont'd } \\
\text { (Colorado) }\end{array}$ & 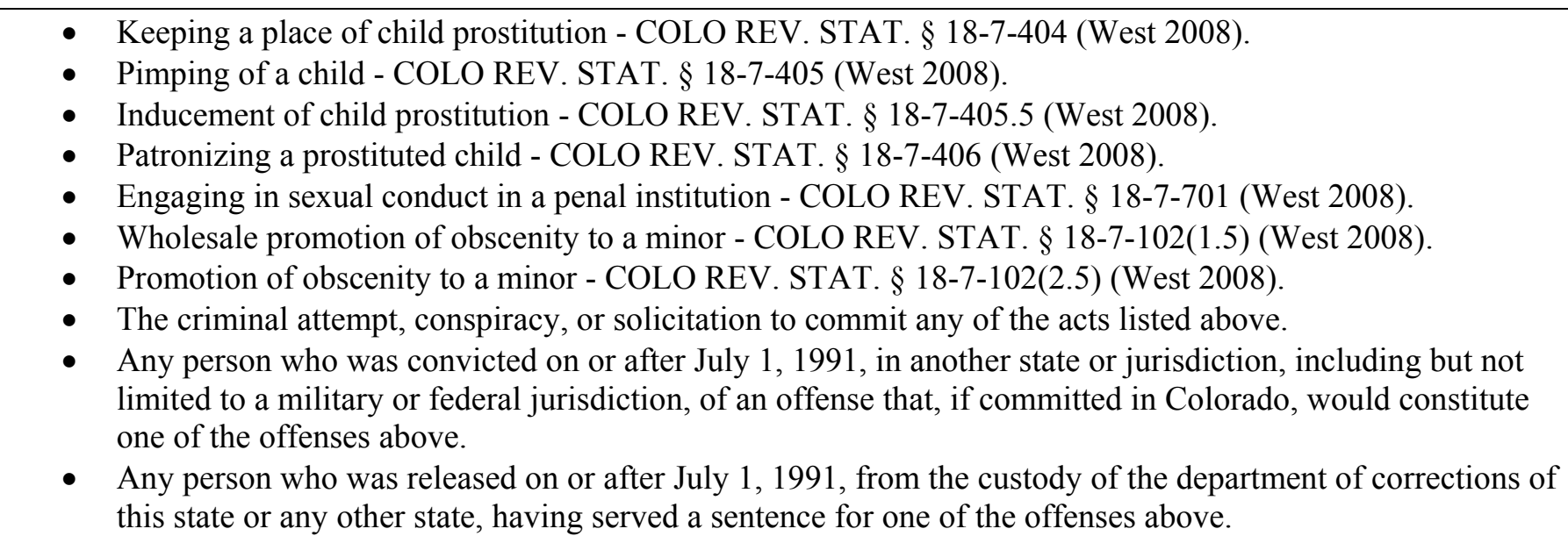 \\
\hline $\begin{array}{l}\text { Sex Offender Registration } \\
\text { Required for Staff Sexual } \\
\text { Misconduct? } \\
\text { (Colorado) }\end{array}$ & $\begin{array}{l}\text { YES. } \\
\text { A staff member convicted of violating C.R.S.A. } \S 18-7-01 \text { "Sexual Conduct in Penal Institutions," must register as a } \\
\text { sex offender. } \\
\text { Note, } \S 18-7-01 \text {, on its face, does not require a convicted staff member to register as a sex offender. However, a } \\
\text { staff member convicted of an "unlawful sexual behavior" is required to register as a sex offender. See, } \S 16-22-103 \text {. } \\
\text { Included in the enumerated offenses of "unlawful sexual behavior" is "Engaging in sexual conduct in a penal } \\
\text { institution under } \S 18-7-01 \text { ". See, } \S 6-22-102 \text {. } \\
\text { A staff member convicted of sexual assault under } \S 18-3-402 \text { is required to register as a sex offender. } \\
\text { A staff member who uses his position of authority to coerce the victim in custody of law to submit to a sexual act, } \\
\text { has committed sexual assault under } \S 18-3-402 \text {. Assualt as defined under } \S 18-3-402 \text { is an enumerated offense of }\end{array}$ \\
\hline
\end{tabular}

** Denotes those states where sex offender registration is required for convictions under the staff sexual misconduct laws of the states. Staff and inmates could also be required to register as sex offenders if the offense were charged under other registrable offenses.

This publication is developed by the NIC/WCL Project on Addressing Prison Rape under NIC Cooperative Agreement 06S20GJJ1.

This is not to be posted or reproduced without permission from the authors.

American University, Washington College of Law

Current as of August 2009 


\section{Fifty State Survey of Adult Sex Offender Registration Requirements}

\section{NIC/WCL Project on Addressing Prison Rape}

\begin{tabular}{|c|c|}
\hline $\begin{array}{l}\text { Sex Offender Registration } \\
\text { Required for Staff Sexual } \\
\text { Misconduct? Cont'd } \\
\text { (Colorado) }\end{array}$ & 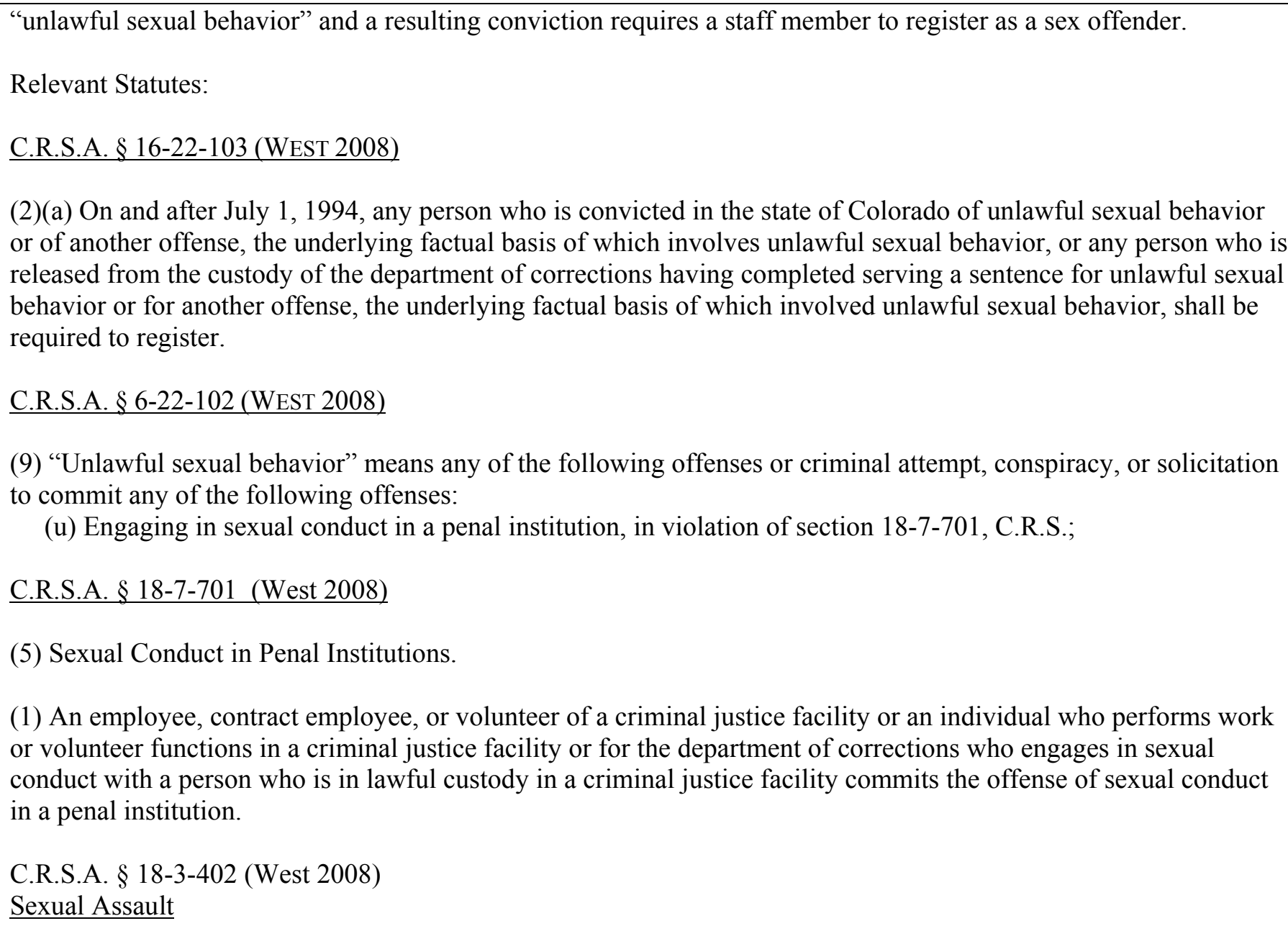 \\
\hline
\end{tabular}

** Denotes those states where sex offender registration is required for convictions under the staff sexual misconduct laws of the states. Staff and inmates could also be required to register as sex offenders if the offense were charged under other registrable offenses.

This publication is developed by the NIC/WCL Project on Addressing Prison Rape under NIC Cooperative Agreement 06S20GJJ1.

This is not to be posted or reproduced without permission from the authors.

American University, Washington College of Law

Current as of August 2009 


\section{Fifty State Survey of Adult Sex Offender Registration Requirements}

\section{NIC/WCL Project on Addressing Prison Rape}

\begin{tabular}{|c|c|}
\hline $\begin{array}{l}\text { Sex Offender Registration } \\
\text { Required for Staff Sexual } \\
\text { Misconduct? Cont'd } \\
\text { (Colorado) }\end{array}$ & $\begin{array}{l}\text { (f) The victim is in custody of law or detained in a hospital or other institution and the actor has supervisory or } \\
\text { disciplinary authority over the victim and uses this position of authority to coerce the victim to submit, unless the } \\
\text { act is incident to a lawful search. }\end{array}$ \\
\hline $\begin{array}{l}\text { Information Maintained in } \\
\text { Sex Offender Registry } \\
\text { (Colorado) }\end{array}$ & $\begin{array}{l}\text { COLO. REV. STAT. } \$ 16-22-110 \text { (West 2008) } \\
\text { (2) The sex offender registry shall provide, at a minimum, the following information to all criminal justice agencies } \\
\text { with regard to registered persons: } \\
\text { (a) Identification of a person's registration status; } \\
\text { (b) A person's date of birth; } \\
\text { (c) Descriptions of the offenses of unlawful sexual behavior of which a person has been convicted; } \\
\text { (d) Identification of persons who are identified as sexually violent predators; } \\
\text { (3)(a) In addition to the sex offender registry, the CBI shall maintain one or more interactive data base systems to } \\
\text { provide, at a minimum, cross validation of a registrant's known names and known addresses with information } \\
\text { maintained by the department of revenue concerning driver's licenses and identification cards issued under article } 2 \\
\text { of title } 42 \text {, C.R.S. Discrepancies between the known names or known addresses listed in the sex offender registry } \\
\text { and information maintained by the department of revenue shall be reported through the Colorado crime information } \\
\text { center to each local law enforcement agency that has jurisdiction over the location of the person's last-known } \\
\text { residences. }\end{array}$ \\
\hline $\begin{array}{l}\text { Community Notification } \\
\text { and Websites } \\
\text { (Colorado) }\end{array}$ & $\begin{array}{l}\text { C.R.S.A. } § 16-22-111 \text { (West 2008) } \\
\text { (1): The CBI shall post a link on the state of Colorado homepage on the internet to a list containing the: } \\
\text { - Names, } \\
\text { - Addresses, and } \\
\text { - Physical descriptions of certain persons and descriptions of the offenses committed by said persons. }\end{array}$ \\
\hline
\end{tabular}

** Denotes those states where sex offender registration is required for convictions under the staff sexual misconduct laws of the states. Staff and inmates could also be required to register as sex offenders if the offense were charged under other registrable offenses.

This publication is developed by the NIC/WCL Project on Addressing Prison Rape under NIC Cooperative Agreement 06S20GJJ1.

This is not to be posted or reproduced without permission from the authors.

American University, Washington College of Law

Current as of August 2009 


\section{Fifty State Survey of Adult Sex Offender Registration Requirements}

\section{NIC/WCL Project on Addressing Prison Rape}

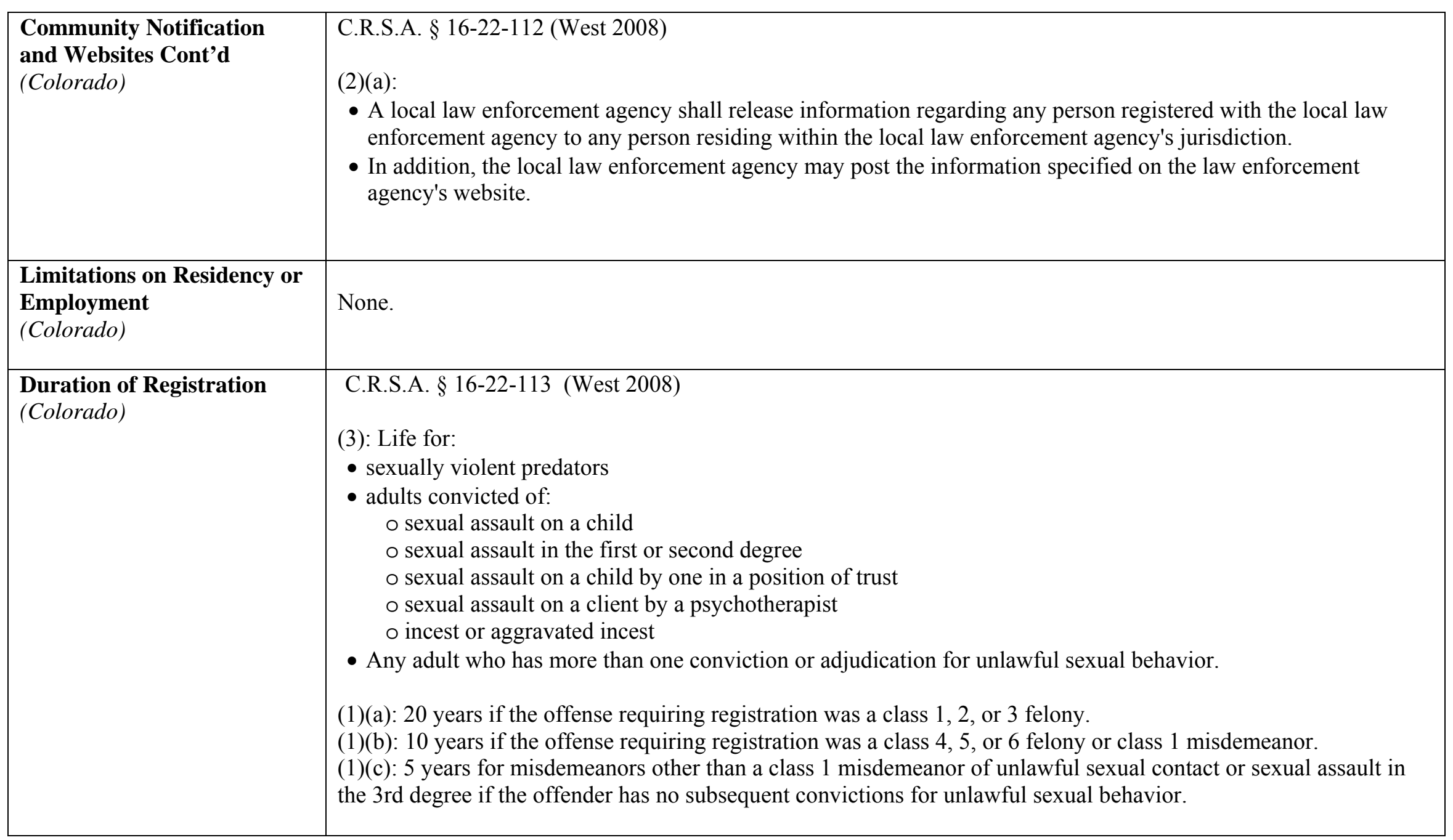

** Denotes those states where sex offender registration is required for convictions under the staff sexual misconduct laws of the states. Staff and inmates could also be required to register as sex offenders if the offense were charged under other registrable offenses.

This publication is developed by the NIC/WCL Project on Addressing Prison Rape under NIC Cooperative Agreement 06S20GJJ1.

This is not to be posted or reproduced without permission from the authors.

American University, Washington College of Law

Current as of August 2009 


\section{Fifty State Survey of Adult Sex Offender Registration Requirements}

\section{NIC/WCL Project on Addressing Prison Rape}

\begin{tabular}{|c|c|}
\hline \multicolumn{2}{|r|}{ CONNECTICUT** } \\
\hline $\begin{array}{l}\text { Registrable Offenses } \\
\text { (Connecticut) }\end{array}$ & 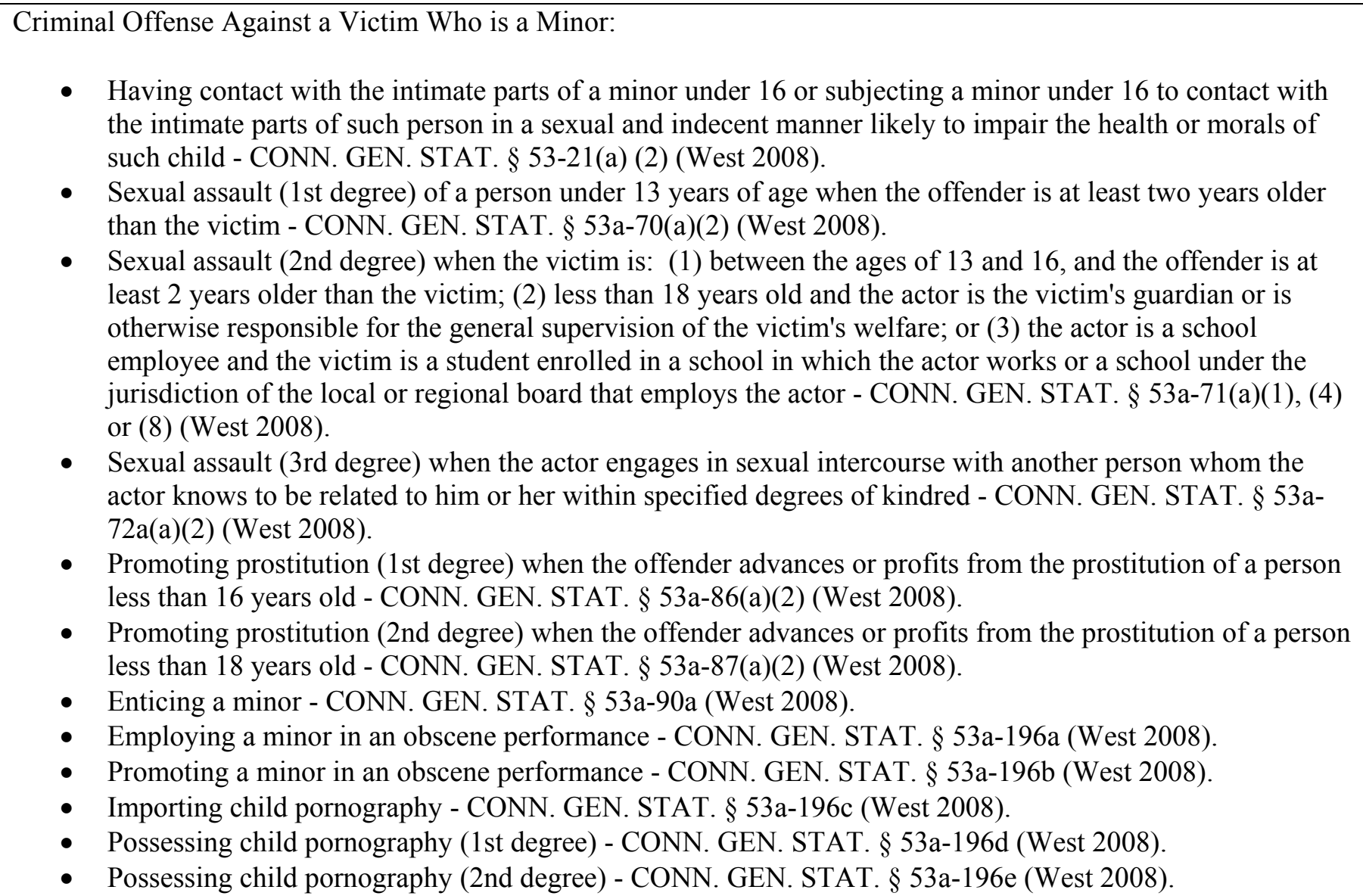 \\
\hline
\end{tabular}

** Denotes those states where sex offender registration is required for convictions under the staff sexual misconduct laws of the states. Staff and inmates could also be required to register as sex offenders if the offense were charged under other registrable offenses.

This publication is developed by the NIC/WCL Project on Addressing Prison Rape under NIC Cooperative Agreement 06S20GJJ1.

This is not to be posted or reproduced without permission from the authors.

American University, Washington College of Law

Current as of August 2009 


\section{Fifty State Survey of Adult Sex Offender Registration Requirements}

\section{NIC/WCL Project on Addressing Prison Rape}

\begin{tabular}{|c|c|}
\hline $\begin{array}{l}\text { Registrable Offenses Cont'd } \\
\text { (Connecticut) }\end{array}$ & 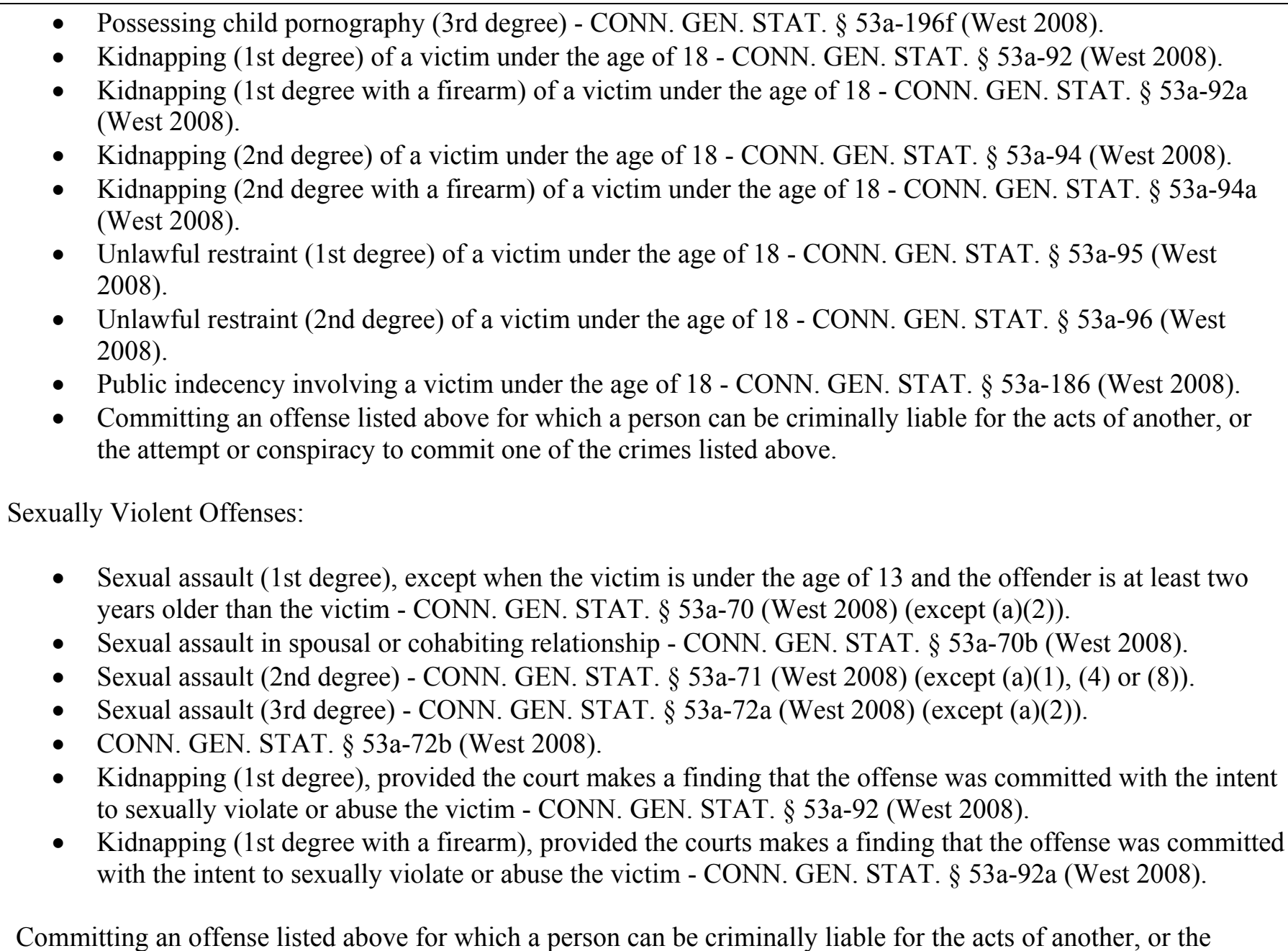 \\
\hline
\end{tabular}

** Denotes those states where sex offender registration is required for convictions under the staff sexual misconduct laws of the states. Staff and inmates could also be required to register as sex offenders if the offense were charged under other registrable offenses.

This publication is developed by the NIC/WCL Project on Addressing Prison Rape under NIC Cooperative Agreement 06S20GJJ1.

This is not to be posted or reproduced without permission from the authors.

American University, Washington College of Law

Current as of August 2009 


\section{Fifty State Survey of Adult Sex Offender Registration Requirements}

\section{NIC/WCL Project on Addressing Prison Rape}

\begin{tabular}{|c|c|}
\hline $\begin{array}{l}\text { Registrable Offenses Cont'd } \\
\text { (Connecticut) }\end{array}$ & attempt or conspiracy to commit one of the crimes listed above \\
\hline $\begin{array}{l}\text { Sex Offender Registration } \\
\text { Required for Staff Sexual } \\
\text { Misconduct? } \\
\text { (Connecticut) }\end{array}$ & $\begin{array}{l}\text { YES. } \\
\text { Staff Members, in their professional capacity, who are convicted of sexual assault in the second degree are required } \\
\text { to register as sex offenders. } \\
\text { C.G.S.A. } \S 53 \text { a-71(West } 2008 \text { ) } \\
\text { Sexual assault in the second degree } \\
\text { (a) A person is guilty of sexual assault in the second degree when such person engages in sexual intercourse with } \\
\text { another person and: } \\
\quad \text { (5) such other person is in custody of law or detained in a hospital or other institution and the actor has } \\
\text { C.G.S.A. } § 54-252 \text { (West } 2008 \text { ) } \\
\text { Registration of person who has committed a sexually violent offense } \\
\text { (a) Any person who has been convicted or found not guilty by reason of mental disease or defect of a sexually } \\
\text { violent offense, and hall maintain such registration for life. } \\
\text { C.G.S.A. } \S 54-250 \text {. (West } 2008 \text { ) } \\
\text { Definitions }\end{array}$ \\
\hline
\end{tabular}

** Denotes those states where sex offender registration is required for convictions under the staff sexual misconduct laws of the states. Staff and inmates could also be required to register as sex offenders if the offense were charged under other registrable offenses.

This publication is developed by the NIC/WCL Project on Addressing Prison Rape under NIC Cooperative Agreement 06S20GJJ1.

This is not to be posted or reproduced without permission from the authors.

American University, Washington College of Law

Current as of August 2009 


\section{Fifty State Survey of Adult Sex Offender Registration Requirements}

\section{NIC/WCL Project on Addressing Prison Rape}

\begin{tabular}{|c|c|}
\hline $\begin{array}{l}\text { Information Maintained in } \\
\text { Sex Offender Registry } \\
\text { (Connecticut) }\end{array}$ & $\begin{array}{l}\text { C.G.S.A. } \$ 54-251(\mathrm{a}), 54-252(\mathrm{a}), 54-253(\mathrm{~b}), \& 54-254(\mathrm{a}) \\
\text { - name } \\
\text { - fingerprints } \\
\text { - photograph } \\
\text { - description of any other identifying characteristics } \\
\text { - blood sample or other biological sample for DNA analysis } \\
\text { - criminal history record } \\
\text { - address of residence } \\
\text { - status as student or employee at institution of higher learning, trade institution or professional institution } \\
\text { - documentation of any treatment received for mental abnormality or personality disorder (for persons convicted } \\
\text { of a sexually violent offense) }\end{array}$ \\
\hline $\begin{array}{l}\text { Community Notification } \\
\text { and Websites } \\
\text { (Connecticut) }\end{array}$ & $\begin{array}{l}\text { C.G.S.A. } \$ 54-258 \\
\text { (a)(1): } \\
\text { - The registry maintained by the Department of Public Safety shall be a public record and shall be accessible to } \\
\text { the public during normal business hours. } \\
\text { - The Department of Public Safety shall make registry information available to the public through the Internet. } \\
\text { - Not less than once per calendar quarter, the Department of Public Safety shall issue notices to all print and } \\
\text { electronic media in the state regarding the availability and means of accessing the registry. } \\
\text { - Each local police department and each state police troop shall keep a record of all registration information } \\
\text { transmitted to it by the Department of Public Safety, and shall make such information accessible to the public } \\
\text { during normal business hours. } \\
\text { (a)(2): Any state agency, the Judicial Department, any state police troop or any local police department may, at its } \\
\text { discretion, notify any government agency, private organization or individual of registration information when such } \\
\text { agency, said department, such troop or such local police department, as the case may be, believes such notification }\end{array}$ \\
\hline
\end{tabular}

** Denotes those states where sex offender registration is required for convictions under the staff sexual misconduct laws of the states. Staff and 34 inmates could also be required to register as sex offenders if the offense were charged under other registrable offenses.

This publication is developed by the NIC/WCL Project on Addressing Prison Rape under NIC Cooperative Agreement 06S20GJJ1.

This is not to be posted or reproduced without permission from the authors.

American University, Washington College of Law

Current as of August 2009 


\section{Fifty State Survey of Adult Sex Offender Registration Requirements}

\section{NIC/WCL Project on Addressing Prison Rape}

\begin{tabular}{|c|c|}
\hline $\begin{array}{l}\text { Community Notification } \\
\text { and Websites Cont'd } \\
\text { (Connecticut) }\end{array}$ & is necessary to protect the public or any individual in any jurisdiction from any person who is subject to registration. \\
\hline \multicolumn{2}{|r|}{ DELAWARE } \\
\hline $\begin{array}{l}\text { Registrable Offenses } \\
\text { (Delaware) }\end{array}$ & $\begin{array}{l}\text { - Indecent Exposure (1st degree) - DEL. CODE ANN. tit. 11, § } 765 \text { (West 2008). } \\
\text { - Indecent exposure (2nd degree), if the offender had previously been convicted of the same offense or any } \\
\text { other sexual offense within five years of the current offense - DEL. CODE ANN. tit. 11, } 764 \text { (West } \\
\text { 2008). }\end{array}$ \\
\hline
\end{tabular}

** Denotes those states where sex offender registration is required for convictions under the staff sexual misconduct laws of the states. Staff and inmates could also be required to register as sex offenders if the offense were charged under other registrable offenses.

This publication is developed by the NIC/WCL Project on Addressing Prison Rape under NIC Cooperative Agreement 06S20GJJ1.

This is not to be posted or reproduced without permission from the authors.

American University, Washington College of Law

Current as of August 2009 


\section{Fifty State Survey of Adult Sex Offender Registration Requirements}

\section{NIC/WCL Project on Addressing Prison Rape}

\begin{tabular}{|c|c|}
\hline $\begin{array}{l}\text { Registrable Offenses Cont'd } \\
\text { (Delaware) }\end{array}$ & 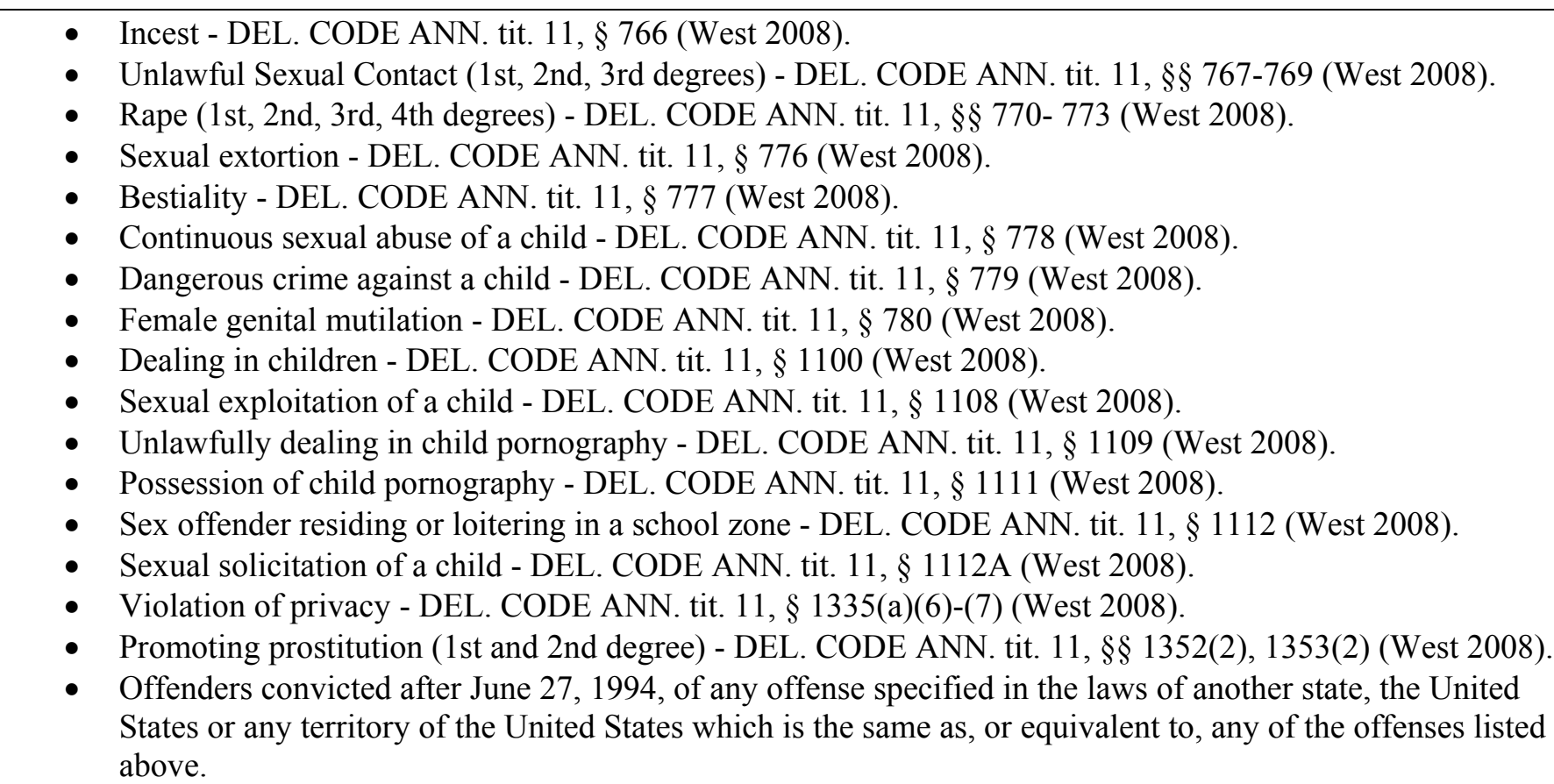 \\
\hline $\begin{array}{l}\text { Sex Offender Registration } \\
\text { Required for Staff Sexual } \\
\text { Misconduct? } \\
\text { (Delaware) }\end{array}$ & NO \\
\hline
\end{tabular}

** Denotes those states where sex offender registration is required for convictions under the staff sexual misconduct laws of the states. Staff and inmates could also be required to register as sex offenders if the offense were charged under other registrable offenses.

This publication is developed by the NIC/WCL Project on Addressing Prison Rape under NIC Cooperative Agreement 06S20GJJ1.

This is not to be posted or reproduced without permission from the authors.

American University, Washington College of Law

Current as of August 2009 


\section{Fifty State Survey of Adult Sex Offender Registration Requirements}

\section{NIC/WCL Project on Addressing Prison Rape}

\begin{tabular}{|c|c|}
\hline $\begin{array}{l}\text { Information Maintained in } \\
\text { Sex Offender Registry } \\
\text { (Delaware) }\end{array}$ & $\begin{array}{l}\text { 11 DEL.C } \S 4120 \\
\text { (d)(2): } \\
\text { - name } \\
\text { - previously used names } \\
\text { - aliases or nicknames } \\
\text { - age } \\
\text { - gender } \\
\text { - race } \\
\text { - physical description of the offender } \\
\text { - identifying factors } \\
\text { - offense history } \\
\text { - sex offender's place of residence, study and employment } \\
\text { - age of the victim } \\
\text { - statement of any relevant conditions of release, discharge, parole or probation } \\
\text { - relationship to the victim } \\
\text { - photograph }\end{array}$ \\
\hline
\end{tabular}

** Denotes those states where sex offender registration is required for convictions under the staff sexual misconduct laws of the states. Staff and inmates could also be required to register as sex offenders if the offense were charged under other registrable offenses.

This publication is developed by the NIC/WCL Project on Addressing Prison Rape under NIC Cooperative Agreement 06S20GJJ1.

This is not to be posted or reproduced without permission from the authors.

American University, Washington College of Law

Current as of August 2009 


\section{Fifty State Survey of Adult Sex Offender Registration Requirements}

\section{NIC/WCL Project on Addressing Prison Rape}

\begin{tabular}{|c|c|}
\hline $\begin{array}{l}\text { Community Notification } \\
\text { and Websites Cont'd } \\
\text { (Delaware) }\end{array}$ & $\begin{array}{l}\text { O newspapers or notices, or } \\
\text { o any combination thereof, to schools, licensed day care facilities, public libraries and other accessible public } \\
\text { facilities within the community. } \\
\text { - "Community notification" also includes notice provided through an alert system added to the Delaware State } \\
\text { Police Sex Offender Registry Internet Web Site that allows governmental agencies, public officials, and } \\
\text { members of the general public to register to receive updates by geographical region whenever a sex offender is } \\
\text { added to, deleted from, or has any change in status on the registry. } \\
\text { (v) (1): } \\
\text { - If a school, school district or licensed child care provider receives community notification, the community } \\
\text { notification must be placed in a binder and kept in the administrative office available to view upon request by } \\
\text { adults and juveniles with adult supervision. } \\
\text { The school, school district or licensed child care provider shall notify parents and staff frequently through their } \\
\text { regular communications of the availability and location of the community notification binder. } \\
\text { (2) The physical posting of community notifications in public school buildings and licensed child care facilities } \\
\text { is prohibited. }\end{array}$ \\
\hline $\begin{array}{l}\text { Limitations on Residency or } \\
\text { Employment } \\
\text { (Delaware) }\end{array}$ & None. \\
\hline $\begin{array}{l}\text { Duration of Registration } \\
\text { (Delaware) }\end{array}$ & $\begin{array}{l}11 \text { DEL.C } \$ 4121 \\
\text { (f)(1)(a): Life for offenders designated to Risk Assessment Tier III or if the offender has been designated to Risk } \\
\text { Assessment Tier II or I, and has previously been convicted of a registrable offense. }\end{array}$ \\
\hline
\end{tabular}

** Denotes those states where sex offender registration is required for convictions under the staff sexual misconduct laws of the states. Staff and inmates could also be required to register as sex offenders if the offense were charged under other registrable offenses.

This publication is developed by the NIC/WCL Project on Addressing Prison Rape under NIC Cooperative Agreement 06S20GJJ1.

This is not to be posted or reproduced without permission from the authors.

American University, Washington College of Law

Current as of August 2009 


\section{Fifty State Survey of Adult Sex Offender Registration Requirements}

\section{NIC/WCL Project on Addressing Prison Rape}

\begin{tabular}{|c|c|}
\hline $\begin{array}{l}\text { Duration of Registration } \\
\text { Cont'd } \\
\text { (Delaware) }\end{array}$ & $\begin{array}{l}\text { (f)(1)(b): } 15 \text { years for offenders released from Level } V \text { custody or for individuals designated to Risk Assessment } \\
\text { Tier II or I who are not otherwise required to register for life. } \\
\text { (f)(2)(b): Individuals designated to Risk Assessment Tier II may petition the court for redesignation to Risk } \\
\text { Assessment Tier I if the victim was not a child under } 18 \text { years of age and } 10 \text { years have elapsed without a } \\
\text { subsequent conviction for any crime (other than a motor vehicle offense). }\end{array}$ \\
\hline & DISTRICT OF COLUMBIA** \\
\hline $\begin{array}{l}\text { Registrable Offenses } \\
\text { (District of Columbia) }\end{array}$ & 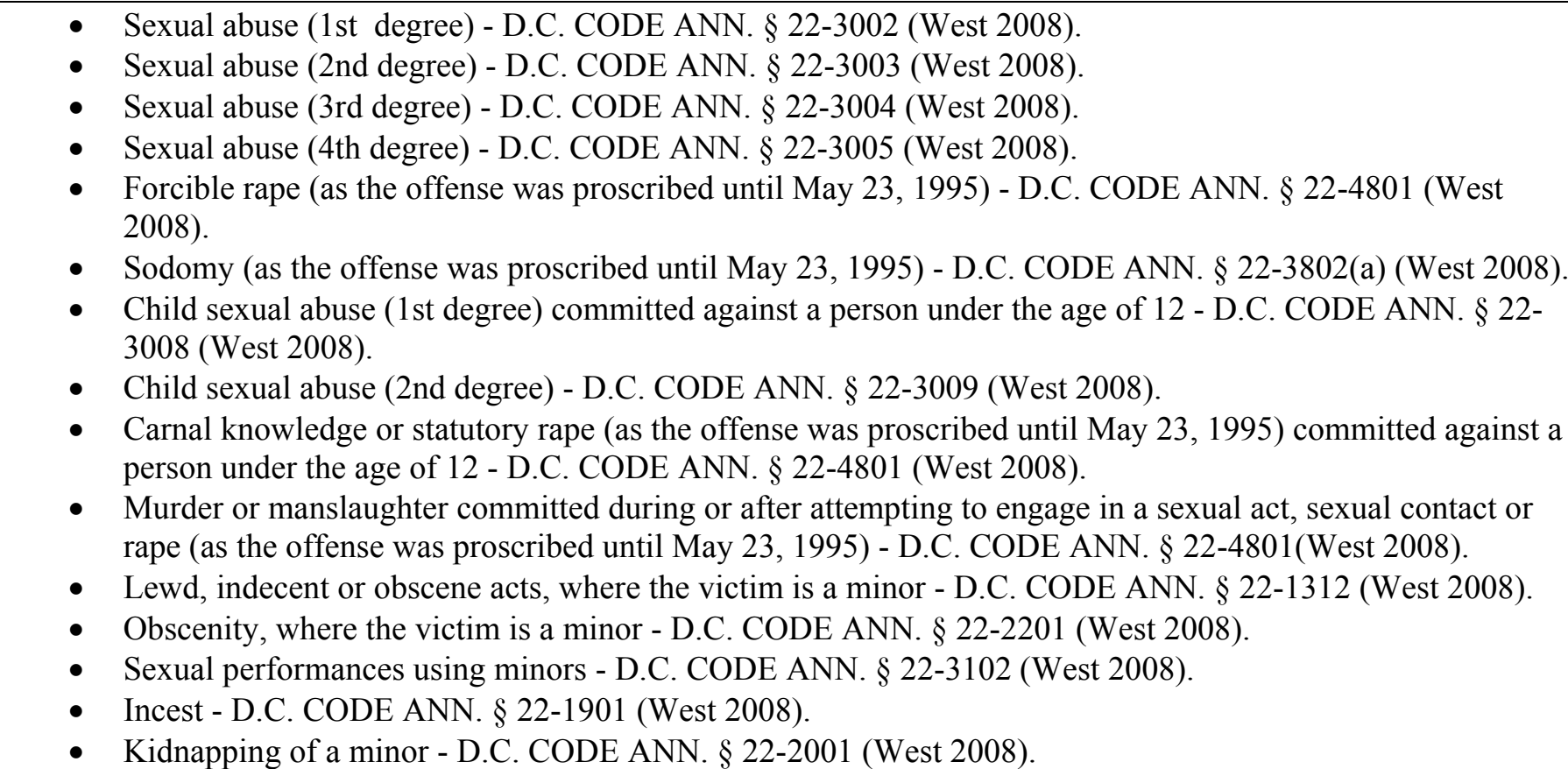 \\
\hline
\end{tabular}

** Denotes those states where sex offender registration is required for convictions under the staff sexual misconduct laws of the states. Staff and inmates could also be required to register as sex offenders if the offense were charged under other registrable offenses.

This publication is developed by the NIC/WCL Project on Addressing Prison Rape under NIC Cooperative Agreement 06S20GJJ1.

This is not to be posted or reproduced without permission from the authors.

American University, Washington College of Law

Current as of August 2009 


\section{Fifty State Survey of Adult Sex Offender Registration Requirements}

\section{NIC/WCL Project on Addressing Prison Rape}

\begin{tabular}{|c|c|}
\hline $\begin{array}{l}\text { Registrable Offenses Cont'd } \\
\text { (District of Columbia) }\end{array}$ & $\begin{array}{l}\text { - Inviting for purposes of prostitution - D.C. CODE ANN. } \S \S 22-2701,2703,2723 \text { (West 2008). } \\
\text { - Sexual abuse of a ward (1st degree) - D.C. CODE ANN. } \S 22-3013 \text { (West 2008). } \\
\text { - Sexual abuse of a ward (2nd degree) - D.C. CODE ANN. } \S 22-3014 \text { (West 2008). } \\
\text { - Sexual abuse of a patient or client (1st degree) - D.C. CODE ANN. } \S 22-3015 \text { (West 2008). } \\
\text { - Any offense that involved a sexual act or sexual contact without consent or with a minor, assaulting or } \\
\text { threatening another with the intent to engage in a sexual act or sexual contact or with the intent to commit } \\
\text { rape, or causing the death of another in the course of, before, or after engaging or attempting to engage in a } \\
\text { sexual act or sexual contact or rape. } \\
\text { - Assault with the intent to commit any other crime (D.C. CODE ANN. } \S 22-403 \text { (West 2008)), or } \\
\text { kidnapping ( D.C. CODE ANN. } \S 22-2001 \text { (West 2008)) or burglary ( D.C. CODE ANN. } \S 22-801 \text { West } \\
\text { 2008)) where the offense involved an intent, attempt or conspiracy to commit an offense listed above. } \\
\text { - The attempt or conspiracy to commit any of the crimes listed above assault with the intent to commit rape, } \\
\text { carnal knowledge, statutory rape, first and second degree sexual abuse, or child abuse as proscribed by DC } \\
\text { CODE ANN. } \S 22-401 \text { (West } 2008 \text { ). } \\
\text { An offense under the law of any state, under federal law, or under the law of any other jurisdiction, which } \\
\text { involved conduct that would constitute an offense described above, or conduct which is substantially } \\
\text { similar to that described above. } \\
\text { Any offense where the offender agrees in a plea agreement to be subject to sex offender registration } \\
\text { requirements. }\end{array}$ \\
\hline $\begin{array}{l}\text { Sex Offender Registration } \\
\text { Required for Staff Sexual } \\
\text { Misconduct? } \\
\text { (District of Columbia) }\end{array}$ & $\begin{array}{l}\text { YES. } \\
\text { Staff Members, in their professional capacity, who are convicted of first or second degree Sexual Abuse of a Ward } \\
\text { are required to register as sex offenders. } \\
\text { D.C. ST. } \S \S 22-3013 \& 22-3014 \text { (West } 2008 \text { ) } \\
\text { First \& Second Degree Sexual Abuse of a Ward }\end{array}$ \\
\hline
\end{tabular}

** Denotes those states where sex offender registration is required for convictions under the staff sexual misconduct laws of the states. Staff and inmates could also be required to register as sex offenders if the offense were charged under other registrable offenses.

This publication is developed by the NIC/WCL Project on Addressing Prison Rape under NIC Cooperative Agreement 06S20GJJ1.

This is not to be posted or reproduced without permission from the authors.

American University, Washington College of Law

Current as of August 2009 


\section{Fifty State Survey of Adult Sex Offender Registration Requirements}

\section{NIC/WCL Project on Addressing Prison Rape}

\begin{tabular}{|c|c|}
\hline $\begin{array}{l}\text { Sex Offender Registration } \\
\text { Required for Staff Sexual } \\
\text { Misconduct? Cont'd } \\
\text { (District of Columbia) }\end{array}$ & $\begin{array}{l}\text { Any staff member, employee, contract employee, consultant, or volunteer at a hospital, treatment facility, detention } \\
\text { or correctional facility, group home, or other institution; or any official custodian of a ward, patient, client, or } \\
\text { prisoner, who engages in a sexual act with a ward, patient, client, or prisoner, or causes a ward, patient, client, or } \\
\text { prisoner to engage in or submit to a sexual act. } \\
\text { D.C. ST. } \S 22-4001 \text { (West } 2008 \text { ) } \\
\text { (8) "Registration offense" means: } \\
\text { (A) An offense under Chapter } 30 \text { of this title; }\end{array}$ \\
\hline $\begin{array}{l}\text { Information Maintained in } \\
\text { Sex Offender Registry } \\
\text { (District of Columbia) }\end{array}$ & $\begin{array}{l}\text { D.C. CODE } \$ 22-4007 \text { (West 2008) } \\
\text { (a)(2) Obtain the information required for registration, which may include such information as the sex offender's } \\
\text { name, all aliases used, date of birth, sex, race, height, weight, eye color, identifying marks and characteristics, } \\
\text { driver's license number, social security number, PDID, DCDC, FBI and NCIC numbers, home address or expected } \\
\text { place of residence, and any current or expected place of employment or school attendance; } \\
\text { (3) Obtain a photograph and set of fingerprints of the sex offender; } \\
\text { (4) Obtain a detailed description of the offense on the basis of which the sex offender is required to register, the } \\
\text { victim impact statement, the date of conviction or other disposition related to the offense, and any sentence } \\
\text { imposed; }\end{array}$ \\
\hline $\begin{array}{l}\text { Community Notification } \\
\text { and Websites } \\
\text { (District of Columbia) }\end{array}$ & $\begin{array}{l}\text { D.C. ST. } § 22-4011 \\
\text { (a): } \\
\text { The Metropolitan Police Department shall have the authority to release and disseminate the information obtained on } \\
\text { sex offenders. The authorized activities of the Metropolitan Police Department under this section include, but are }\end{array}$ \\
\hline
\end{tabular}

** Denotes those states where sex offender registration is required for convictions under the staff sexual misconduct laws of the states. Staff and inmates could also be required to register as sex offenders if the offense were charged under other registrable offenses.

This publication is developed by the NIC/WCL Project on Addressing Prison Rape under NIC Cooperative Agreement 06S20GJJ1.

This is not to be posted or reproduced without permission from the authors.

American University, Washington College of Law

Current as of August 2009 


\section{Fifty State Survey of Adult Sex Offender Registration Requirements}

\section{NIC/WCL Project on Addressing Prison Rape}

\section{Community Notification} and Websites Cont'd

(District of Columbia) not limited to, active and passive notification to all or parts of the community concerning a sex offender, including but not limited to:

- Victims and witnesses;

- Public and private educational institutions, day care entities and other institutions or organizations that provide services to or employ individuals who may be victimized by a sex offender;

- Members of the public or governmental agencies requesting information on identified individuals for

employment or foster care background checks or similar purposes;

- The public at large; and

- Any unit of the Metropolitan Police Department and other law enforcement agencies.

(b) (1):

Active notification under this section refers to affirmatively informing persons or entities about sex offenders.

Authorized means of active notification include, but are not limited to:

- Community meetings,

- Flyers,

- Telephone calls,

- Door-to-door contacts,

- Electronic notification,

- Direct mailings, and

- Media releases.

(B) Passive notification under this section refers to making information about sex offenders available for public inspection or in response to inquiries. Authorized means of passive notification include, but are not limited to:

- Internet postings,

- Making registration lists and information about registrants available for inspection at police stations and other locations, and

- Responding to written or oral inquiries in person, through the mail, by telephone, or through email or other electronic means.

- The Metropolitan Police Department shall develop and implement a system to make available for public

** Denotes those states where sex offender registration is required for convictions under the staff sexual misconduct laws of the states. Staff and inmates could also be required to register as sex offenders if the offense were charged under other registrable offenses.

This publication is developed by the NIC/WCL Project on Addressing Prison Rape under NIC Cooperative Agreement 06S20GJJ1.

This is not to be posted or reproduced without permission from the authors.

American University, Washington College of Law

Current as of August 2009 


\section{Fifty State Survey of Adult Sex Offender Registration Requirements}

\section{NIC/WCL Project on Addressing Prison Rape}

\begin{tabular}{|c|c|}
\hline $\begin{array}{l}\text { Community Notification } \\
\text { and Websites Cont'd } \\
\text { (District of Columbia) }\end{array}$ & $\begin{array}{l}\text { inspection by means of the Internet all or part of the portions of the sex offender registry relating to Class A and } \\
\text { Class B offenders. } \\
\text { (3): } \\
\text { - Passive notification may be carried out concerning any sex offender, except that information made available } \\
\text { under this section for public inspection by means of the Internet shall be limited to information on Class A and } \\
\text { Class B offenders. } \\
\text { - Active notification concerning Class A offenders may be provided to any person or entity. } \\
\text { - Active notification concerning Class B and Class C offenders may be provided to: } \\
\text { o law enforcement agencies; } \\
\text { o organizations that deal with or provide services to vulnerable populations or victims of sexual offenses, } \\
\text { including but not limited to schools, day care centers, other child care and youth-serving organizations, } \\
\text { facilities caring for or providing services to the elderly or persons with impairments, shelters, churches, and } \\
\text { victims rights and victims services entities; } \\
\text { o victims of and witnesses to a sex offender's crime or crimes and parents, guardians, and family member of } \\
\text { such persons; and } \\
\text { o any person where the Metropolitan Police Department has information indicating that the sex offender may } \\
\text { pose a specific risk to that person, and parents, guardians, and family members of such a person. }\end{array}$ \\
\hline $\begin{array}{l}\text { Duration of Registration } \\
\text { (District of Columbia) }\end{array}$ & $\begin{array}{l}\text { D.C. ST. } \S 22-4002 \\
\text { (b): Life for a sex offender who: } \\
\text { - Committed a registration offense that is a lifetime registration offense as defined in Section 22-4001(6) } \\
\text { - Was determined to be a sexual psychopath under } \S 22-3803 \text { through } 22-3811 \\
\text { - Has been subject on } 2 \text { or more occasions to a disposition described in } \S 22-4001(3)(A) \text { that involved a felony } \\
\text { registration offense or a registration offense against a minor }\end{array}$ \\
\hline
\end{tabular}

** Denotes those states where sex offender registration is required for convictions under the staff sexual misconduct laws of the states. Staff and inmates could also be required to register as sex offenders if the offense were charged under other registrable offenses.

This publication is developed by the NIC/WCL Project on Addressing Prison Rape under NIC Cooperative Agreement 06S20GJJ1.

This is not to be posted or reproduced without permission from the authors.

American University, Washington College of Law

Current as of August 2009 


\section{Fifty State Survey of Adult Sex Offender Registration Requirements}

\section{NIC/WCL Project on Addressing Prison Rape}

\begin{tabular}{|c|c|}
\hline $\begin{array}{l}\text { Duration of Registration } \\
\text { Cont'd } \\
\text { (District of Columbia) }\end{array}$ & $\begin{array}{l}\text { - Has been subject to } 2 \text { or more dispositions described in } \S 22-4001(3)(\mathrm{A}) \text {, relating to different victims, each of } \\
\text { which involved a felony registration offense or a registration offense against a minor. } \\
\text { (a): } 10 \text { years for any person not subject to lifetime registration. }\end{array}$ \\
\hline & FLORIDA** \\
\hline $\begin{array}{l}\text { Registrable Offenses } \\
\text { (Florida) }\end{array}$ & 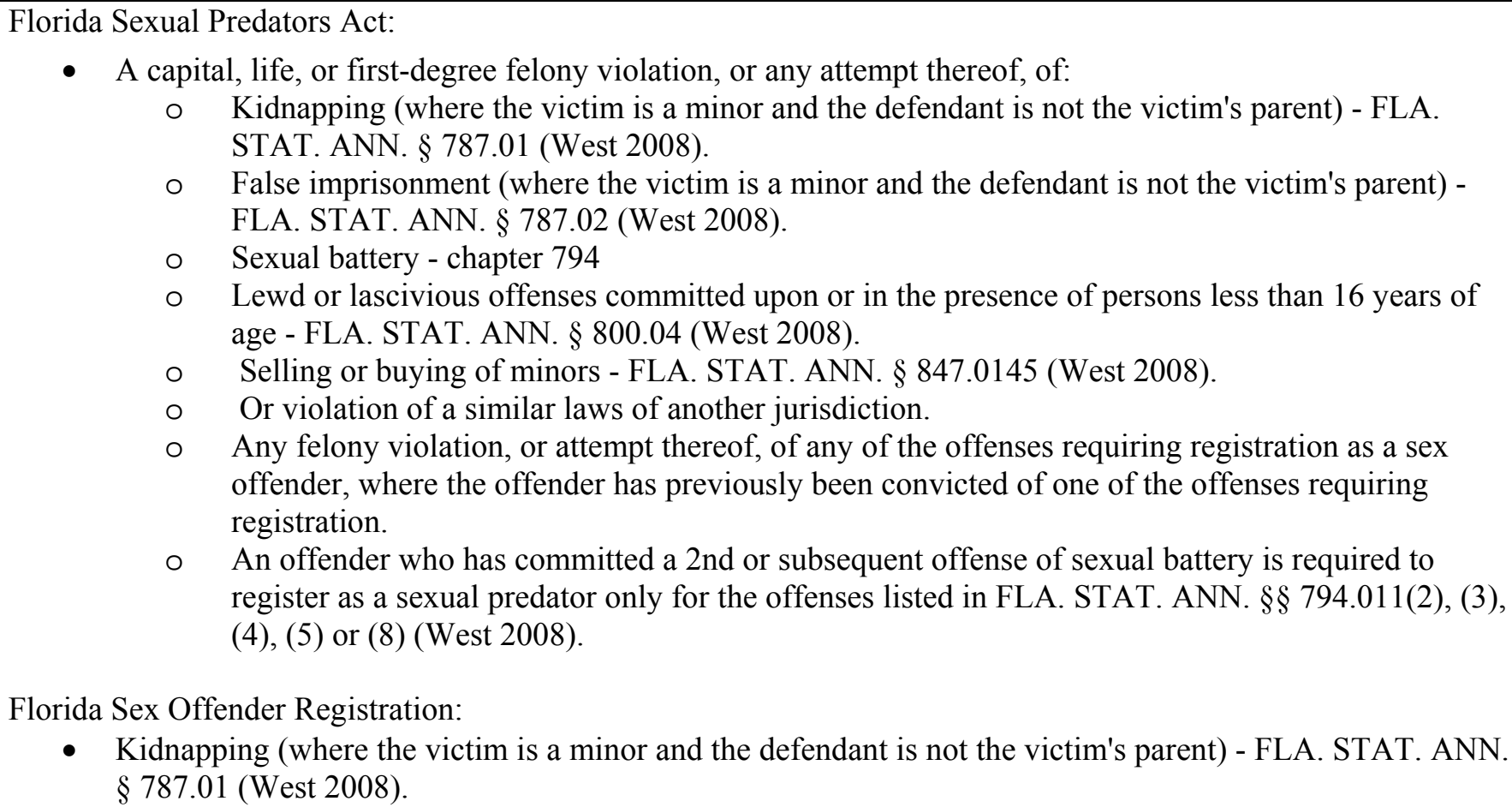 \\
\hline
\end{tabular}

** Denotes those states where sex offender registration is required for convictions under the staff sexual misconduct laws of the states. Staff and inmates could also be required to register as sex offenders if the offense were charged under other registrable offenses.

This publication is developed by the NIC/WCL Project on Addressing Prison Rape under NIC Cooperative Agreement 06S20GJJ1.

This is not to be posted or reproduced without permission from the authors.

American University, Washington College of Law

Current as of August 2009 


\section{Fifty State Survey of Adult Sex Offender Registration Requirements}

\section{NIC/WCL Project on Addressing Prison Rape}

Registrable Offenses Cont'd

(Florida)
- False imprisonment (where the victim is a minor and the defendant is not the victim's parent) - FLA. STAT. ANN. § 787.02 (West 2008).

- Luring or enticing a child (where the victim is a minor and the defendant is not the victim's parent) - FLA. STAT. ANN. § 787.025 (West 2008).

Sexual Battery, including:

- Sexual Battery FLA. STAT. ANN. § 794.011 (except 794.011(10)) (West 2008).

- Sexual battery by multiple perpetrators - FLA. STAT. ANN. § 794.023 (West 2008). Unlawful sexual activity with certain minors - FLA. STAT. ANN. § 794.05 (West 2008).

- $\quad$ Procuring person under age of 18 for prostitution - FLA. STAT. ANN. $§ 796.03$ (West 2008).

- Lewd or lascivious offenses committed upon or in the presence of persons less than 16 years of age - FLA. STAT. ANN. § 800.04 (West 2008).

- Lewd or lascivious offenses committed upon or in the presence of an elderly person or disabled person FLA. STAT. ANN. § 825.1025 (West 2008).

- $\quad$ Sexual performance by a child - FLA. STAT. ANN. $\S 827.071$ (West 2008).

- Obscenity - FLA. STAT. ANN. § 847.0133 (West 2008).

- Computer pornography - FLA. STAT. ANN. § 847.0135 (West 2008).

- Transmission of pornography by electronic device or equipment - FLA. STAT. ANN. § 847.0137 (West 2008).

- Transmission of material harmful to minors to a minor by electronic device or equipment prohibited - FLA. STAT. ANN. § 847.0138 (West 2008).

- Selling or buying of minors - FLA. STAT. ANN. $\S 847.0145$ (West 2008).

- Attempting, soliciting, or conspiring to commit, any of the criminal offenses proscribed.

Any person who establishes or maintains a residence in this state and who has been designated as a sexual predator, as a sexually violent predator, or by another sexual offender designation in another state or jurisdiction and was, as a result of such designation, subjected to registration or community or public notification, or both, or would be if the person were a resident of that state or jurisdiction.

** Denotes those states where sex offender registration is required for convictions under the staff sexual misconduct laws of the states. Staff and inmates could also be required to register as sex offenders if the offense were charged under other registrable offenses.

This publication is developed by the NIC/WCL Project on Addressing Prison Rape under NIC Cooperative Agreement 06S20GJJ1.

This is not to be posted or reproduced without permission from the authors.

American University, Washington College of Law

Current as of August 2009 


\section{Fifty State Survey of Adult Sex Offender Registration Requirements}

\section{NIC/WCL Project on Addressing Prison Rape}

\begin{tabular}{|c|c|}
\hline $\begin{array}{l}\text { Sex Offender Registration } \\
\text { Required for Staff Sexual } \\
\text { Misconduct? } \\
\text { (Florida) }\end{array}$ & $\begin{array}{l}\text { YES. } \\
\text { Correctional Officers in their professional capacity, who are convicted of First Degree Sexual Battery are required } \\
\text { to register as sex offenders. } \\
\text { FL. ST. } \S 794.011(4) \text { (West 2008) } \\
\text { First Degree Sexual Battery committed by a correctional officer in a custodial setting. } \\
\text { (g) When the offender is a law enforcement officer, correctional officer, or correctional probation officer as defined } \\
\text { by s. } 943.10(1),(2),(3),(6),(7),(8) \text {, or (9), who is certified under the provisions of s. } 943.1395 \text { or is an elected } \\
\text { official exempt from such certification by virtue of s. } 943.253 \text {, or any other person in a position of control or } \\
\text { authority in a probation, community control, controlled release, detention, custodial, or similar setting, and such } \\
\text { officer, official, or person is acting in such a manner as to lead the victim to reasonably believe that the offender is } \\
\text { in a position of control or authority as an agent or employee of government. } \\
\text { FL. ST. § 943.0435 (West 2008) } \\
\text { (a) 1. "Sexual offender" means a person who meets the criteria in sub-subparagraph a., sub-subparagraph b., sub- } \\
\text { subparagraph c., or sub-subparagraph d., as follows: } \\
\text { a. (I) Has been convicted of committing, or attempting, soliciting, or conspiring to commit, any of the criminal } \\
\text { offenses proscribed in the following statutes in this state or similar offenses in another jurisdiction: s. } 787.01 \text {, s. } \\
787.02 \text {, or s. } 787.025(2)(c), \text { where the victim is a minor and the defendant is not the victim's parent or guardian; s. } \\
794.011 \text {, }\end{array}$ \\
\hline $\begin{array}{l}\text { Information Maintained in } \\
\text { Sex Offender Registry } \\
\text { (Florida) }\end{array}$ & $\begin{array}{l}\text { FLA. STAT. ANN. } § 943.0435 \text { (West 2008) } \\
\text { (2)(b) Provide his or her name, date of birth, social security number, race, sex, height, weight, hair and eye color, } \\
\text { tattoos or other identifying marks, occupation and place of employment, address of permanent or legal residence } \\
\text { or address of any current temporary residence, within the state and out of state, including a rural route address }\end{array}$ \\
\hline
\end{tabular}

** Denotes those states where sex offender registration is required for convictions under the staff sexual misconduct laws of the states. Staff and 46 inmates could also be required to register as sex offenders if the offense were charged under other registrable offenses.

This publication is developed by the NIC/WCL Project on Addressing Prison Rape under NIC Cooperative Agreement 06S20GJJ1.

This is not to be posted or reproduced without permission from the authors.

American University, Washington College of Law

Current as of August 2009 


\section{Fifty State Survey of Adult Sex Offender Registration Requirements}

\section{NIC/WCL Project on Addressing Prison Rape}

\begin{tabular}{|c|c|}
\hline $\begin{array}{l}\text { Information Maintained in } \\
\text { Sex Offender Registry } \\
\text { (Florida) }\end{array}$ & $\begin{array}{l}\text { and a post office box, any electronic mail address and any instant message name required to be provided pursuant } \\
\text { to paragraph }(4)(\mathrm{d}) \text {, date and place of each conviction, and a brief description of the crime or crimes committed } \\
\text { by the offender. A post office box shall not be provided in lieu of a physical residential address }\end{array}$ \\
\hline $\begin{array}{l}\text { Community Notification } \\
\text { and Websites } \\
\text { (Florida) }\end{array}$ & $\begin{array}{l}\text { FL. ST. } \$ 943.046 \\
\text { (1): } \\
\text { - Any state or local law enforcement agency may release to the public any criminal history information and other } \\
\text { information regarding a criminal offender, including, but not limited to, public notification by the agency of the } \\
\text { information, unless the information is confidential. }\end{array}$ \\
\hline $\begin{array}{l}\text { Limitations on Residency or } \\
\text { Employment } \\
\text { (Florida) }\end{array}$ & $\begin{array}{l}\text { FL. ST. } \$ 943.04351 \\
\text { A state agency or governmental subdivision, prior to making any decision to appoint or employ a person to work, } \\
\text { whether for compensation or as a volunteer, at any park, playground, day care center, or other place where children } \\
\text { regularly congregate, must conduct a search of that person's name against the registration information regarding } \\
\text { sexual predators and sexual offenders. } \\
\text { FL. ST. } \S 775.21 \\
\text { (11) Sexual predators, as defined in Section } 775.21(4) \text {, commit a } 3^{\text {rd }} \text { degree felony if they work, either for } \\
\text { compensation or as a volunteer, at any business, school, day care center, park, playground, or other place where } \\
\text { children regularly congregate. }\end{array}$ \\
\hline $\begin{array}{l}\text { Duration of Registration } \\
\text { (Florida) }\end{array}$ & $\begin{array}{l}\text { FL. ST. } \S 943.0435 \\
\text { (11) Sex offenders must register for life. } \\
\text { (11)(a) Sex offenders may be relieved from the obligation to register if: }\end{array}$ \\
\hline
\end{tabular}

** Denotes those states where sex offender registration is required for convictions under the staff sexual misconduct laws of the states. Staff and inmates could also be required to register as sex offenders if the offense were charged under other registrable offenses.

This publication is developed by the NIC/WCL Project on Addressing Prison Rape under NIC Cooperative Agreement 06S20GJJ1.

This is not to be posted or reproduced without permission from the authors.

American University, Washington College of Law

Current as of August 2009 


\section{Fifty State Survey of Adult Sex Offender Registration Requirements}

\section{NIC/WCL Project on Addressing Prison Rape}

\begin{tabular}{|c|c|}
\hline $\begin{array}{l}\text { Duration of Registration } \\
\text { Cont'd } \\
\text { (Florida) }\end{array}$ & $\begin{array}{l}\text { - The registrant has not been arrested for any misdemeanor or felony offense for } 20 \text { years; or } \\
\text { - The registrant was under } 18 \text { years of age at the time of the offense, the victim was at least } 12 \text { years old, and at } \\
\text { least } 10 \text { years have elapsed since the registrant was arrested for any felony or misdemeanor. }\end{array}$ \\
\hline & GEORGIA \\
\hline $\begin{array}{l}\text { Registrable Offenses } \\
\text { (Georgia) }\end{array}$ & 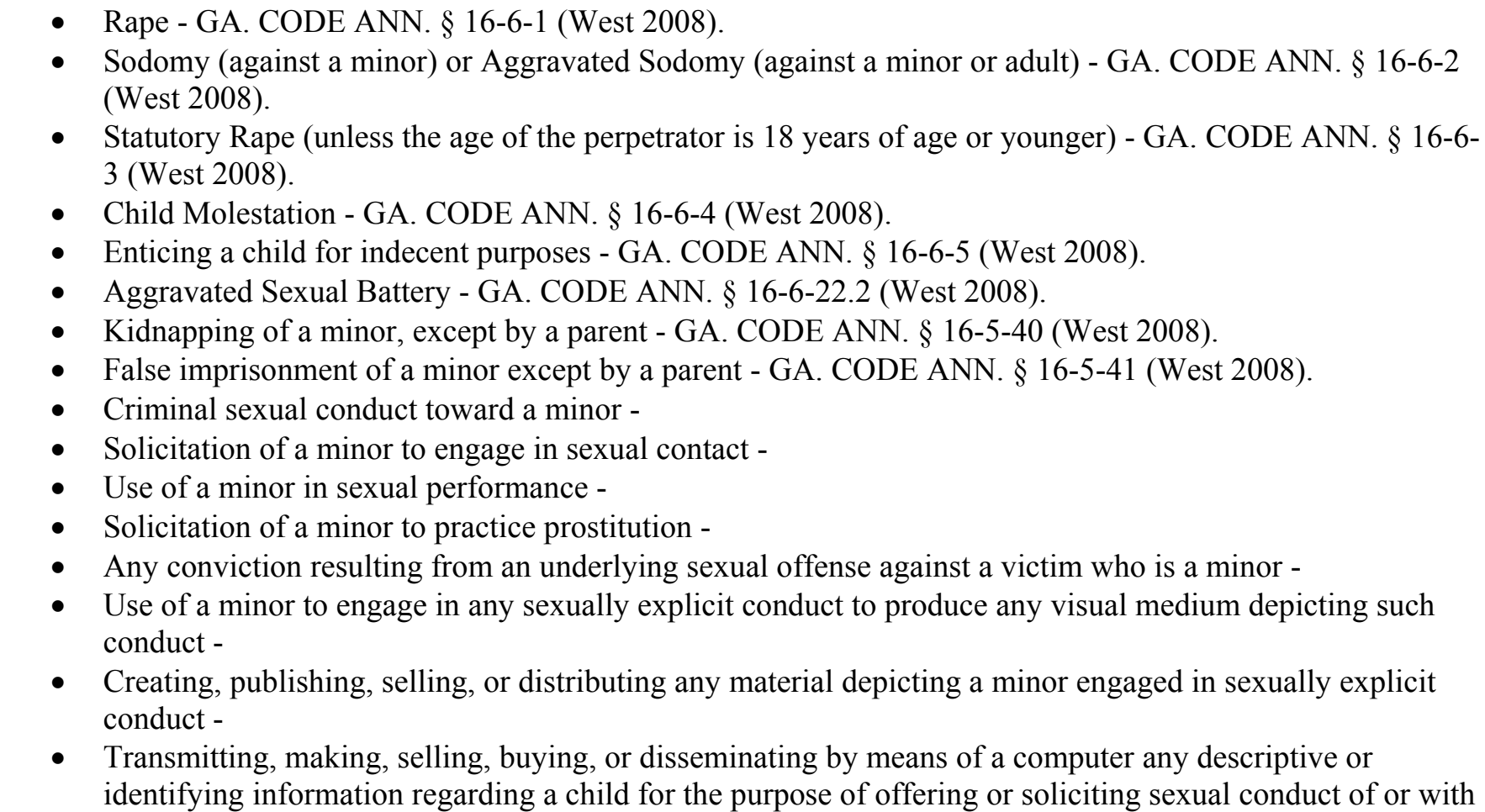 \\
\hline
\end{tabular}

** Denotes those states where sex offender registration is required for convictions under the staff sexual misconduct laws of the states. Staff and 48 inmates could also be required to register as sex offenders if the offense were charged under other registrable offenses.

This publication is developed by the NIC/WCL Project on Addressing Prison Rape under NIC Cooperative Agreement 06S20GJJ1.

This is not to be posted or reproduced without permission from the authors.

American University, Washington College of Law

Current as of August 2009 


\section{Fifty State Survey of Adult Sex Offender Registration Requirements}

\section{NIC/WCL Project on Addressing Prison Rape}

\begin{tabular}{|c|c|}
\hline $\begin{array}{l}\text { Registrable Offenses } \\
\text { (Georgia) }\end{array}$ & $\begin{array}{l}\text { a child or the visual depicting of such conduct } \\
\text { Any conduct which, by its nature, is a sexual offense against a minor (this language replaces GA. CODE ANN. } \S \\
42-1-12(a)(4)(A)(\text { vii) (West 2008). }\end{array}$ \\
\hline $\begin{array}{l}\text { Sex Offender Registration } \\
\text { Required for Staff Sexual } \\
\text { Misconduct? } \\
\text { (Georgia) }\end{array}$ & NO \\
\hline $\begin{array}{l}\text { Information Maintained in } \\
\text { Sex Offender Registry } \\
\text { (Georgia) }\end{array}$ & $\begin{array}{l}\text { GA. ST. } § 42-1-12 \text { (West 2008) } \\
\text { (a)(16): "Required registration information" means: } \\
\text { (A) Name; social security number; age; race; sex; date of birth; height; weight; hair color, eye color, fingerprints; } \\
\text { and photograph; } \\
\text { (B) Address of any permanent residence and address of any current temporary residence, within the state or out } \\
\text { of state, and, if applicable in addition to the address, a rural route address and a post office box; } \\
\text { (C) If the place of residence is a motor vehicle or trailer, provide the vehicle identification number, the license } \\
\text { tag number, and a description, including color scheme, of the motor vehicle or trailer; } \\
\text { (D) If the place of residence is a mobile home, provide the mobile home location permit number; the name and } \\
\text { address of the owner of the home; a description, including the color scheme of the mobile home; and, if } \\
\text { applicable, a description of where the mobile home is located on the property; } \\
\text { (E) If the place of residence is a manufactured home, provide the name and address of the owner of the home; a } \\
\text { description, including the color scheme of the manufactured home; and, if applicable, a description of where } \\
\text { the manufactured home is located on the property; } \\
\text { (F) If the place of residence is a vessel, live-aboard vessel, or houseboat, provide the hull identification number; } \\
\text { the manufacturer's serial number; the name of the vessel, live-aboard vessel, or houseboat; the registration } \\
\text { number; and a description, including color scheme, of the vessel, live-aboard vessel, or houseboat; } \\
\text { (G) Date of employment, place of any employment, and address of employer; } \\
\text { (H) Place of vocation and address of the place of vocation; }\end{array}$ \\
\hline
\end{tabular}

** Denotes those states where sex offender registration is required for convictions under the staff sexual misconduct laws of the states. Staff and inmates could also be required to register as sex offenders if the offense were charged under other registrable offenses.

This publication is developed by the NIC/WCL Project on Addressing Prison Rape under NIC Cooperative Agreement 06S20GJJ1.

This is not to be posted or reproduced without permission from the authors.

American University, Washington College of Law

Current as of August 2009 


\section{Fifty State Survey of Adult Sex Offender Registration Requirements}

\section{NIC/WCL Project on Addressing Prison Rape}

\begin{tabular}{|c|c|}
\hline $\begin{array}{l}\text { Information Maintained in } \\
\text { Sex Offender Registry } \\
\text { Cont'd } \\
\text { (Georgia) }\end{array}$ & $\begin{array}{l}\text { (I) Vehicle make, model, color, and license tag number; } \\
\text { (J) If enrolled, employed, or carrying on a vocation at an institution of higher education in this state, the name, } \\
\text { address, and county of each institution, including each campus attended, and enrollment or employment } \\
\text { status; and } \\
\text { (K) The name of the crime or crimes for which the sexual offender is registering and the date released from } \\
\text { prison or placed on probation, parole, or supervised release. }\end{array}$ \\
\hline $\begin{array}{l}\text { Community Notification } \\
\text { and Websites } \\
\text { (Georgia) }\end{array}$ & $\begin{array}{l}\text { GA. ST. } § 42-1-12 \text { (West 2008) } \\
\text { (i) The sheriff's office in each county shall: } \\
\text { (1) Prepare and maintain a list of all sexual offenders and sexually dangerous predators residing in each county. } \\
\text { Such list shall include the: } \\
\text { - Sexual offender's name; } \\
\text { - Age; } \\
\text { - Physical description; } \\
\text { - Address; } \\
\text { - Crime of conviction, including conviction date and the jurisdiction of the conviction; } \\
\text { - Photograph; and } \\
\text { - The risk assessment classification level provided by the board, and } \\
\text { - An explanation of how the board classifies sexual offenders and sexually dangerous predators; } \\
\text { (2) Electronically submit and update all information provided by the sexual offender within two working days to the } \\
\text { Georgia Bureau of Investigation in a manner prescribed by the Georgia Bureau of Investigation; } \\
\text { (3) Maintain and post a list of } \\
\text { every sexual offender } \\
\text { residing in each county: } \\
\text { (A) In the sheriff's office; } \\
\text { (B) In any county administrative building; } \\
\text { (C) In the main administrative building for any municipal corporation; }\end{array}$ \\
\hline
\end{tabular}

** Denotes those states where sex offender registration is required for convictions under the staff sexual misconduct laws of the states. Staff and inmates could also be required to register as sex offenders if the offense were charged under other registrable offenses.

This publication is developed by the NIC/WCL Project on Addressing Prison Rape under NIC Cooperative Agreement 06S20GJJ1.

This is not to be posted or reproduced without permission from the authors.

American University, Washington College of Law

Current as of August 2009 


\section{Fifty State Survey of Adult Sex Offender Registration Requirements}

\section{NIC/WCL Project on Addressing Prison Rape}

\begin{tabular}{|c|c|}
\hline $\begin{array}{l}\text { Community Notification } \\
\text { and Websites Cont'd } \\
\text { (Georgia) }\end{array}$ & $\begin{array}{l}\text { (D) In the office of the clerk of the superior court so that such list is available to the public; and } \\
\text { (E) On a website maintained by the sheriff of the county for the posting of general information; } \\
\text { (4) Update the public notices required by paragraph (3) of this Code section within two working days; } \\
\text { (5) Inform the public of the presence of sexual offenders in each community. }\end{array}$ \\
\hline $\begin{array}{l}\text { Limitations on Residency or } \\
\text { Employment } \\
\text { (Georgia) }\end{array}$ & $\begin{array}{l}\text { GA. ST. } \S \S 42-1-15 \text { (West 2008) } \\
\text { (a): Sex offenders may not reside or loiter within } 1000 \text { feet of any child care facility, church, school or area where } \\
\text { minors congregate. } \\
\text { (b)(1): Sex offenders may not work at any child care facility, church, school or by any business that is located } \\
\text { within } 1000 \text { feet of such facility. } \\
\text { (b)(2): Sexually dangerous predators may not be employed by any business or entity within } 1000 \text { feet of an area } \\
\text { where minors congregate. }\end{array}$ \\
\hline $\begin{array}{l}\text { Duration of Registration } \\
\text { (Georgia) }\end{array}$ & $\begin{array}{l}\text { GA. ST. } \$ 42-1-12 \text { (West 2008) } \\
\text { (f)(6)-(7): Life for persons: } \\
\text { - With one or more prior convictions for a registrable offense, } \\
\text { - With convictions for an aggravated registrable offense, or } \\
\text { - That have been determined to be a sexually violent predator. } \\
\text { (g): } 10 \text { years for sex offenders with a single conviction for a registrable offense. }\end{array}$ \\
\hline & \\
\hline
\end{tabular}

** Denotes those states where sex offender registration is required for convictions under the staff sexual misconduct laws of the states. Staff and inmates could also be required to register as sex offenders if the offense were charged under other registrable offenses.

This publication is developed by the NIC/WCL Project on Addressing Prison Rape under NIC Cooperative Agreement 06S20GJJ1.

This is not to be posted or reproduced without permission from the authors.

American University, Washington College of Law

Current as of August 2009 


\section{Fifty State Survey of Adult Sex Offender Registration Requirements}

\section{NIC/WCL Project on Addressing Prison Rape}

\begin{tabular}{|c|c|}
\hline $\begin{array}{l}\text { Registrable Offenses } \\
\text { (Guam) }\end{array}$ & 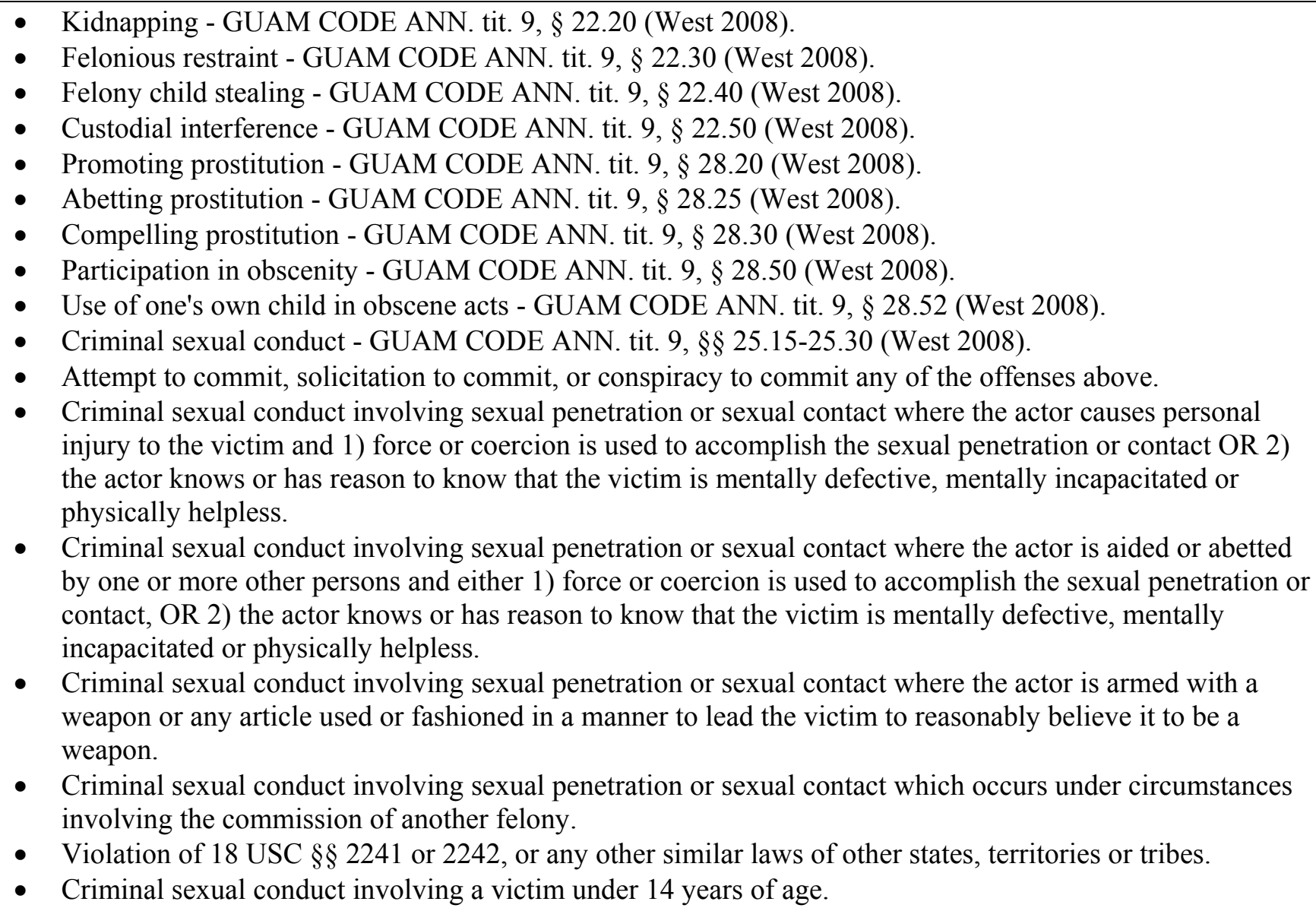 \\
\hline
\end{tabular}

** Denotes those states where sex offender registration is required for convictions under the staff sexual misconduct laws of the states. Staff and inmates could also be required to register as sex offenders if the offense were charged under other registrable offenses.

This publication is developed by the NIC/WCL Project on Addressing Prison Rape under NIC Cooperative Agreement 06S20GJJ1.

This is not to be posted or reproduced without permission from the authors.

American University, Washington College of Law

Current as of August 2009 


\section{Fifty State Survey of Adult Sex Offender Registration Requirements}

\section{NIC/WCL Project on Addressing Prison Rape}

\begin{tabular}{|c|c|}
\hline $\begin{array}{l}\text { Sex Offender Registration } \\
\text { Required for Staff Sexual } \\
\text { Misconduct? }^{1} \\
\text { (Guam) }\end{array}$ & NO \\
\hline
\end{tabular}

** Denotes those states where sex offender registration is required for convictions under the staff sexual misconduct laws of the states. Staff and inmates could also be required to register as sex offenders if the offense were charged under other registrable offenses.

This publication is developed by the NIC/WCL Project on Addressing Prison Rape under NIC Cooperative Agreement 06S20GJJ1.

This is not to be posted or reproduced without permission from the authors.

American University, Washington College of Law

Current as of August 2009 


\section{Fifty State Survey of Adult Sex Offender Registration Requirements}

\section{NIC/WCL Project on Addressing Prison Rape}

\begin{tabular}{|c|c|}
\hline $\begin{array}{l}\text { Community Notification } \\
\text { and Websites } \\
\text { (Guam) }\end{array}$ & $\begin{array}{l}\text { GU ST T. 9, } \S 89.10 \text { (West 2008) } \\
\text { (d) } \\
\text { - The Judiciary of Guam, Sex Offender Registry Management Office shall maintain an Internet web-page } \\
\text { - Tedicated to persons required to register, which shall contain the information that is required to be released. } \\
\text { - The Judiciary of Guam, Sex Offender Registry Management Office shall transmit released information } \\
\text { concerning Level One and Level Two Offenders to the Guam Public School System, the Guam Community } \\
\text { College, the University of Guam, all public and private schools, day care centers, victim shelters and victim } \\
\text { advocates on the first week of every month. } \\
\text { - The Judiciary of Guam, Sex Offender Registry Management Office may transmit information concerning Level } \\
\text { One and Level Two Offenders directly to the media for dissemination. }\end{array}$ \\
\hline $\begin{array}{l}\text { Limitations on Residency or } \\
\text { Employment } \\
\text { (Guam) }\end{array}$ & None. \\
\hline \multicolumn{2}{|r|}{ HAWAII** } \\
\hline $\begin{array}{l}\text { Registrable Offenses } \\
\text { (Hawaii) }\end{array}$ & $\begin{array}{l}\text { - Kidnapping of a minor, except by a parent - HAW. REV. STAT. ANN. § 707-720 (West 2008). } \\
\text { - Unlawful imprisonment (1st degree) of a minor, except by a parent - HAW. REV. STAT. ANN. § 707-721 } \\
\text { (West 2008). } \\
\text { - The attempt, criminal solicitation, or criminal conspiracy to commit the crimes above. }\end{array}$ \\
\hline
\end{tabular}

** Denotes those states where sex offender registration is required for convictions under the staff sexual misconduct laws of the states. Staff and inmates could also be required to register as sex offenders if the offense were charged under other registrable offenses.

This publication is developed by the NIC/WCL Project on Addressing Prison Rape under NIC Cooperative Agreement 06S20GJJ1.

This is not to be posted or reproduced without permission from the authors.

American University, Washington College of Law

Current as of August 2009 


\section{Fifty State Survey of Adult Sex Offender Registration Requirements}

\section{NIC/WCL Project on Addressing Prison Rape}

\begin{tabular}{|c|c|}
\hline $\begin{array}{l}\text { Registrable Offenses Cont'd } \\
\text { (Hawaii) }\end{array}$ & 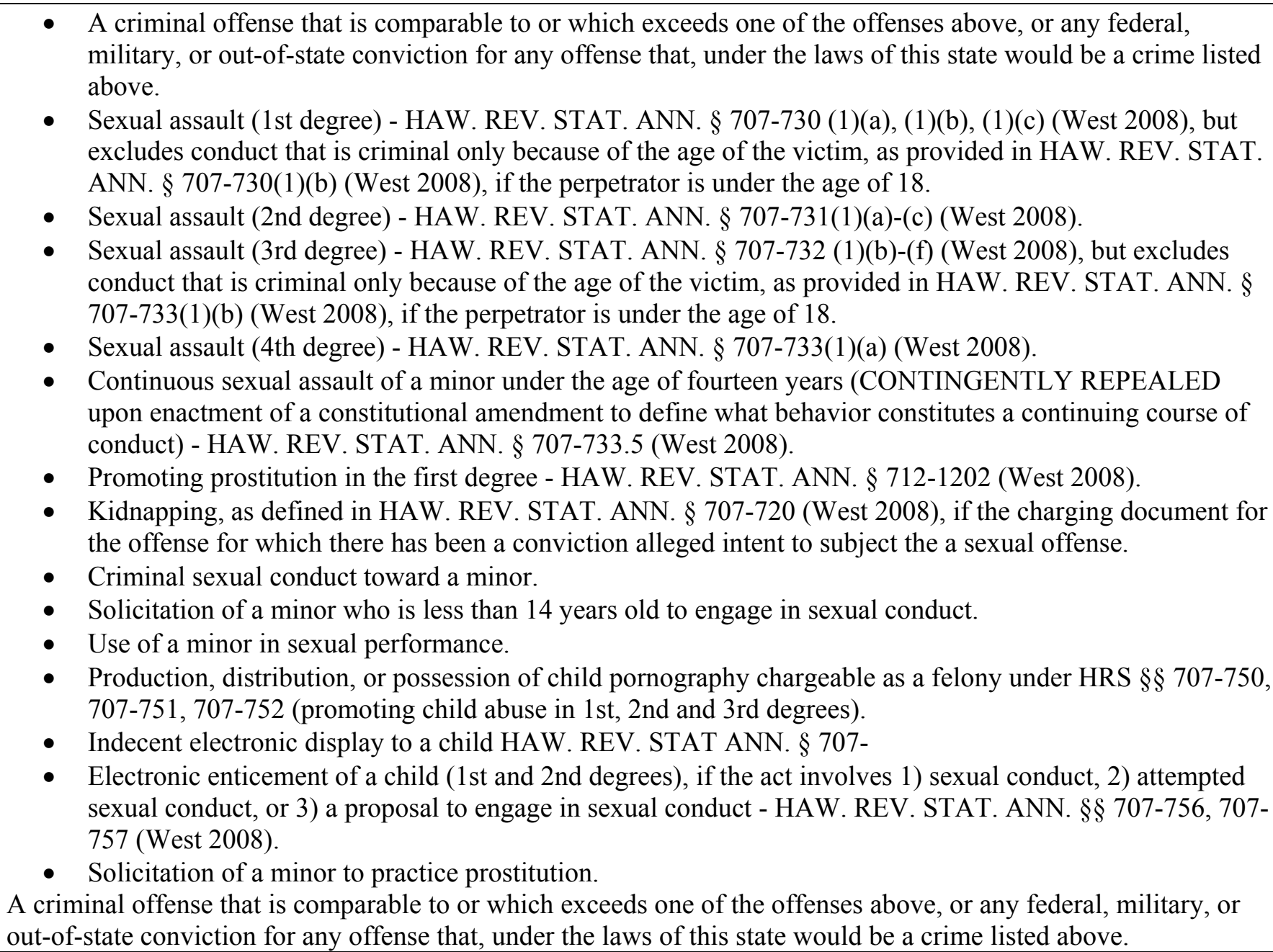 \\
\hline
\end{tabular}

** Denotes those states where sex offender registration is required for convictions under the staff sexual misconduct laws of the states. Staff and inmates could also be required to register as sex offenders if the offense were charged under other registrable offenses.

This publication is developed by the NIC/WCL Project on Addressing Prison Rape under NIC Cooperative Agreement 06S20GJJ1.

This is not to be posted or reproduced without permission from the authors.

American University, Washington College of Law

Current as of August 2009 


\section{Fifty State Survey of Adult Sex Offender Registration Requirements}

\section{NIC/WCL Project on Addressing Prison Rape}

\begin{tabular}{|c|c|}
\hline $\begin{array}{l}\text { Sex Offender Registration } \\
\text { Required for Staff Sexual } \\
\text { Misconduct? } \\
\text { (Hawaii) }\end{array}$ & $\begin{array}{l}\text { YES. } \\
\text { H.R.S. } \S 707-731(1)(\mathrm{c}) \& 707-732(1)(\mathrm{e}) \text { (West 2008) } \\
\text { Second and Third Degree Sexual Assaults in a Custodial Setting. } \\
\text { (1) A person commits the offense of sexual assault in the third degree if: } \\
\text { (e) The person, while employed: } \\
\quad \text { (i) In a state correctional facility; } \\
\quad \text { (ii) By a private company providing services at a correctional facility; } \\
\quad \text { director of public safety and having received notice of this statute; } \\
\text { (iv) By a private correctional facility operating in the State of Hawaii; o } \\
\text { (v) As a law enforcement officer as defined in section } 710-1000(13) \text {, } \\
\text { 707-732(1)(e): knowingly subjects to sexual contact an imprisoned person, a person confined to a detention facility, } \\
\text { a person committed to the director of public safety, a person residing in a private correctional facility operating in } \\
\text { the State of Hawaii, or a person in custody, or causes the person to have sexual contact with the actor; } \\
\text { 707-731(1)(c): knowingly subjects to sexual penetration an imprisoned person, a person confined to a detention } \\
\text { facility, a person committed to the director of public safety, a person residing in a private correctional facility } \\
\text { operating in the State of Hawaii, or a person in custody. }\end{array}$ \\
\hline $\begin{array}{l}\text { Information Maintained in } \\
\text { Sex Offender Registry } \\
\text { (Hawaii) }\end{array}$ & $\begin{array}{l}\text { H.R.S. } \$ 846 \mathrm{E}-2 \text { (West 2008) } \\
\text { (c) Registration information for each covered offender shall consist of a recent photograph, verified fingerprints, } \\
\text { and a signed statement by the covered offender containing: } \\
\text { (1) The name, all prior names, and all aliases used by the covered offender or under which the covered offend }\end{array}$ \\
\hline
\end{tabular}

** Denotes those states where sex offender registration is required for convictions under the staff sexual misconduct laws of the states. Staff and 56 inmates could also be required to register as sex offenders if the offense were charged under other registrable offenses.

This publication is developed by the NIC/WCL Project on Addressing Prison Rape under NIC Cooperative Agreement 06S20GJJ1.

This is not to be posted or reproduced without permission from the authors.

American University, Washington College of Law

Current as of August 2009 


\section{Fifty State Survey of Adult Sex Offender Registration Requirements}

\section{NIC/WCL Project on Addressing Prison Rape}

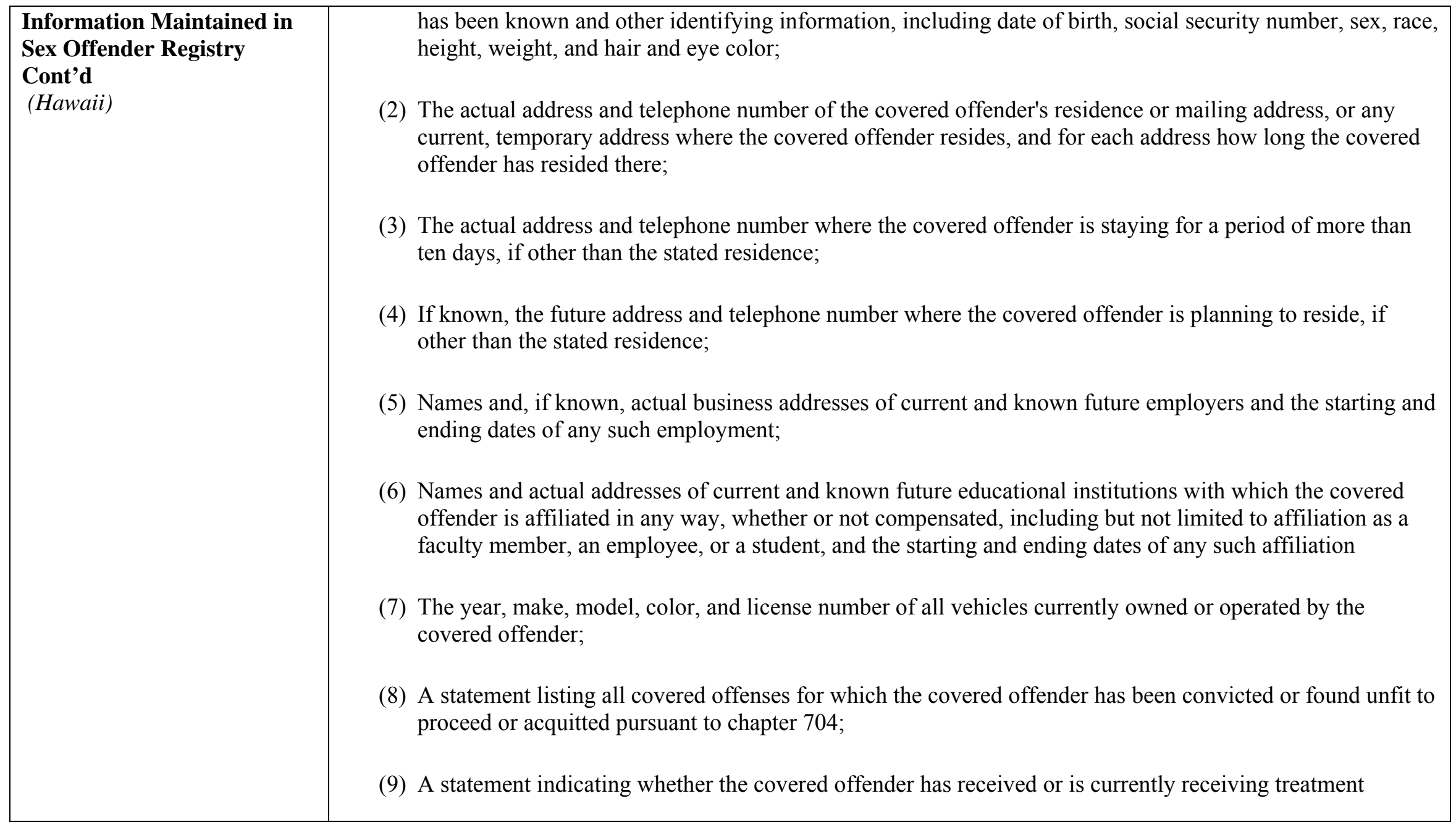

** Denotes those states where sex offender registration is required for convictions under the staff sexual misconduct laws of the states. Staff and inmates could also be required to register as sex offenders if the offense were charged under other registrable offenses.

This publication is developed by the NIC/WCL Project on Addressing Prison Rape under NIC Cooperative Agreement 06S20GJJ1.

This is not to be posted or reproduced without permission from the authors.

American University, Washington College of Law

Current as of August 2009 


\section{Fifty State Survey of Adult Sex Offender Registration Requirements}

\section{NIC/WCL Project on Addressing Prison Rape}

\begin{tabular}{|c|c|}
\hline $\begin{array}{l}\text { Information Maintained in } \\
\text { Sex Offender Registry } \\
\text { Cont'd } \\
\text { (Hawaii) }\end{array}$ & $\begin{array}{l}\text { ordered by a court of competent jurisdiction or by the Hawaii paroling authority; } \\
\text { (10) A statement indicating whether the covered offender is a United States citizen; and } \\
\text { (11) Any additional identifying information about the covered offender. }\end{array}$ \\
\hline $\begin{array}{l}\text { Community Notification } \\
\text { and Websites } \\
\text { (Hawaii) }\end{array}$ & $\begin{array}{l}\text { H.R.S. } \$ 846 E-3 \text { (West 2008) } \\
\text { (a) Registration information shall be disclosed as follows: } \\
\text { (1) The information shall be disclosed to law enforcement agencies for law enforcement purposes; } \\
\text { (2) The information shall be disclosed to government agencies conducting confidential background checks; } \\
\text { (3) The attorney general and any county police department shall release public information. } \\
\text { (d) Public access authorized by this section shall be accomplished by the following methods: } \\
\text { (1) Public access to the public information for each covered offender subject to subsection (c), paragraphs (1) } \\
\text { through (4) shall be provided by both public Internet access and on-site public access or; } \\
\text { (2) Public access to the public information for each covered offender subject to subsection (c), paragraph (5) } \\
\text { shall be provided by on-site public access; provided that on-site public access shall be provided for each } \\
\text { covered offender at the Hawaii criminal justice data center and at one or more designated police stations in } \\
\text { each county, to be designated by the attorney general, between the hours of } 8: 00 \text { a.m. and } 4: 30 \text { p.m. on } \\
\text { weekdays, excluding holidays. }\end{array}$ \\
\hline $\begin{array}{l}\text { Limitations on Residency or } \\
\text { Employment } \\
\text { (Hawaii) }\end{array}$ & None. \\
\hline
\end{tabular}

** Denotes those states where sex offender registration is required for convictions under the staff sexual misconduct laws of the states. Staff and inmates could also be required to register as sex offenders if the offense were charged under other registrable offenses.

This publication is developed by the NIC/WCL Project on Addressing Prison Rape under NIC Cooperative Agreement 06S20GJJ1.

This is not to be posted or reproduced without permission from the authors.

American University, Washington College of Law

Current as of August 2009 


\section{Fifty State Survey of Adult Sex Offender Registration Requirements}

\section{NIC/WCL Project on Addressing Prison Rape}

\begin{tabular}{|c|c|}
\hline $\begin{array}{l}\text { Duration of Registration } \\
\text { (Hawaii) }\end{array}$ & $\begin{array}{l}\text { H.R.S. } § 846 \mathrm{E}-2 \text { (West 2008) } \\
\text { (a) Sex offenders must register for life. } \\
\text { H.R.S. } § 846 \mathrm{E}-10 \text { (West 2008) } \\
\text { A sex offender who has substantially complied with registration and who is not an aggravated sex offender, repeat } \\
\text { sex offender or sexually violent predator may petition the court for termination of his/her registration requirements: } \\
\text { - After } 25 \text { years if the most serious registration offense was a class A felony or non-Hawaii equivalent } \\
\text { - After } 15 \text { years if the most serious registration offense was a class B felony or non-Hawaii equivalent } \\
\text { - After } 10 \text { years if the most serious offense was a class } C \text { felony or its non-Hawaii equivalent, or a misdemeanor. }\end{array}$ \\
\hline & IDAHO $* *$ \\
\hline $\begin{array}{l}\text { Registrable Offenses } \\
\text { (Idaho) }\end{array}$ & 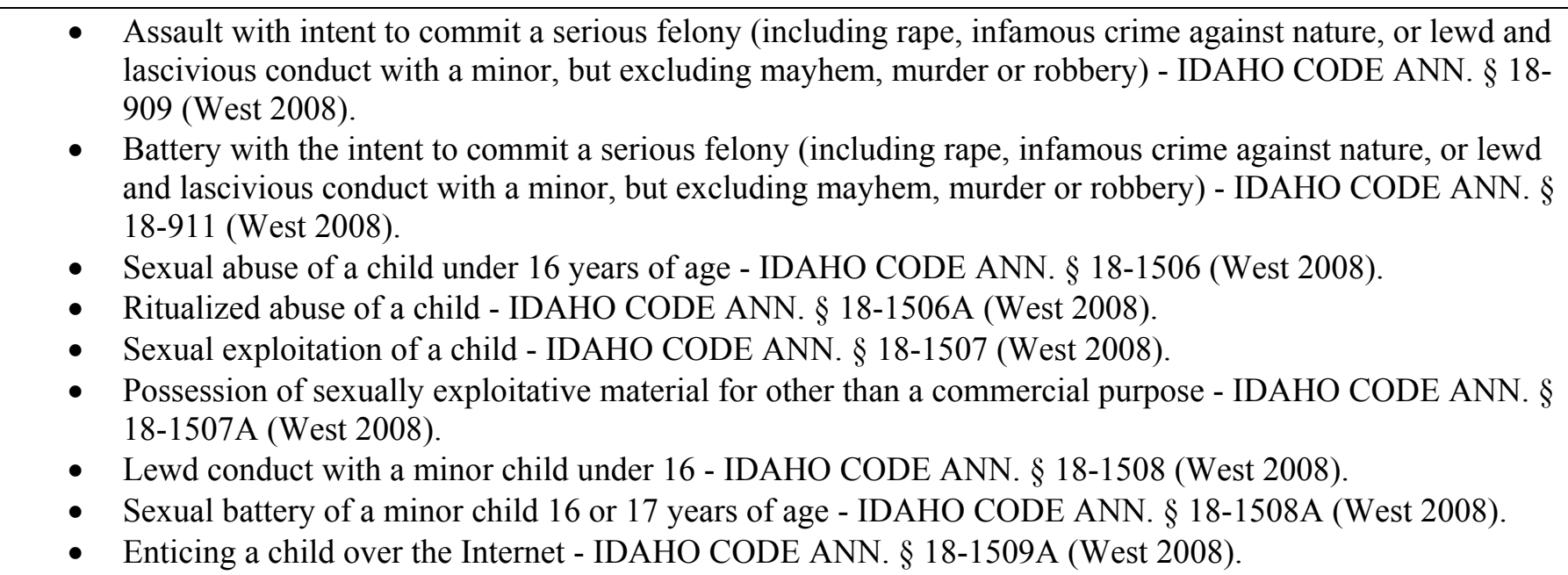 \\
\hline
\end{tabular}

** Denotes those states where sex offender registration is required for convictions under the staff sexual misconduct laws of the states. Staff and inmates could also be required to register as sex offenders if the offense were charged under other registrable offenses.

This publication is developed by the NIC/WCL Project on Addressing Prison Rape under NIC Cooperative Agreement 06S20GJJ1.

This is not to be posted or reproduced without permission from the authors.

American University, Washington College of Law

Current as of August 2009 


\section{Fifty State Survey of Adult Sex Offender Registration Requirements}

\section{NIC/WCL Project on Addressing Prison Rape}

\begin{tabular}{|c|c|}
\hline $\begin{array}{l}\text { Registrable Offenses Cont'd } \\
\text { (Idaho) }\end{array}$ & 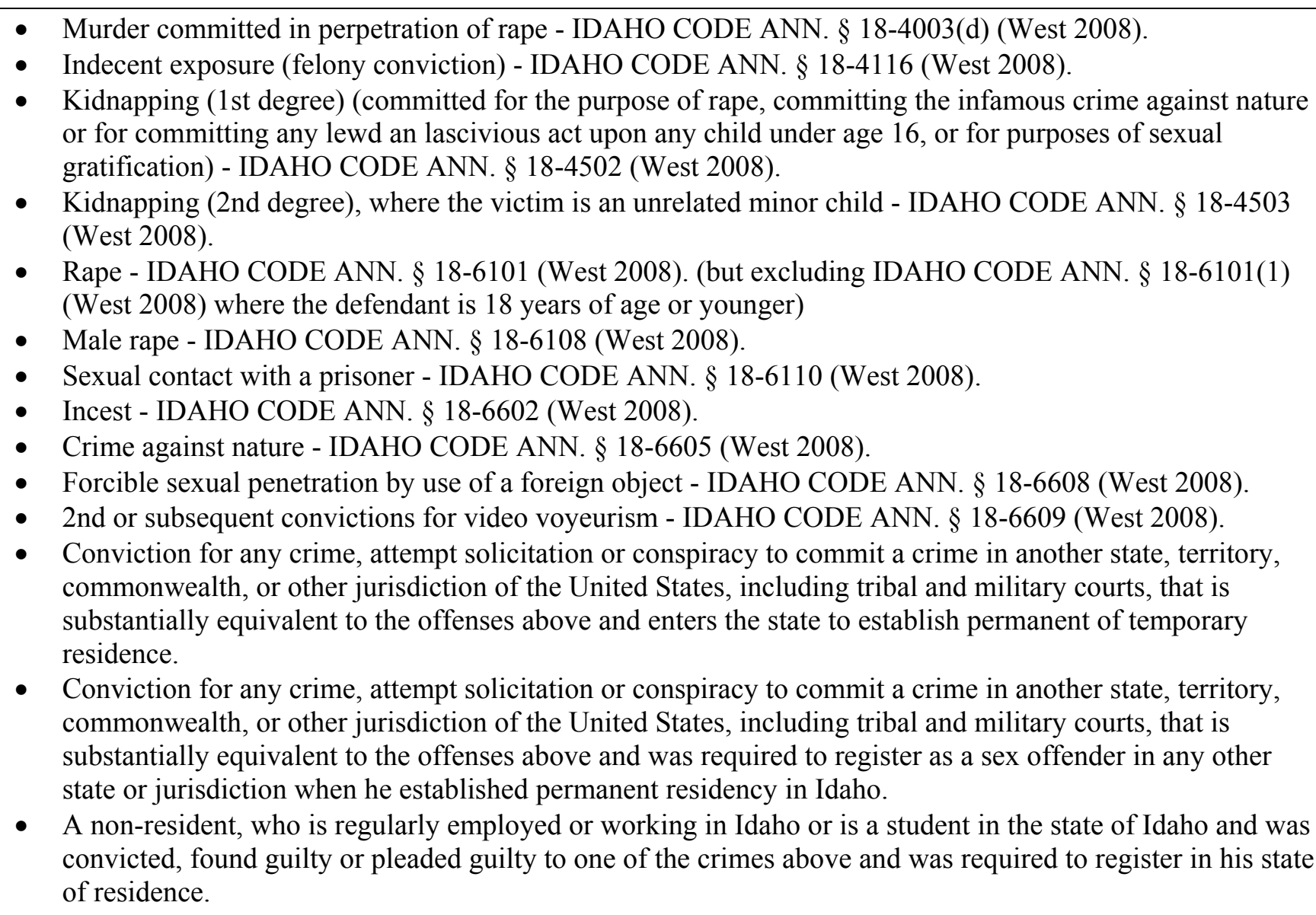 \\
\hline
\end{tabular}

** Denotes those states where sex offender registration is required for convictions under the staff sexual misconduct laws of the states. Staff and inmates could also be required to register as sex offenders if the offense were charged under other registrable offenses.

This publication is developed by the NIC/WCL Project on Addressing Prison Rape under NIC Cooperative Agreement 06S20GJJ1.

This is not to be posted or reproduced without permission from the authors.

American University, Washington College of Law

Current as of August 2009 


\section{Fifty State Survey of Adult Sex Offender Registration Requirements}

\section{NIC/WCL Project on Addressing Prison Rape}

\begin{tabular}{|c|c|}
\hline $\begin{array}{l}\text { Sex Offender Registration } \\
\text { Required for Staff Sexual } \\
\text { Misconduct? } \\
\text { (Idaho) }\end{array}$ & $\begin{array}{l}\text { YES. } \\
009 \text { Idaho Laws Ch. } 116 \text { (S.B. 1003) § 18-6110 (West 2008). } \\
\text { Sexual contact with a prisoner } \\
\text { (1) It is a felony for any employee of the Idaho department of correction, Idaho department of juvenile corrections } \\
\text { or any officer, employee or agent of a state, local or private correctional facility, as those terms are defined in } \\
\text { section 18-101A, Idaho Code, to have sexual contact with a prisoner or juvenile offender, not their spouse, whether } \\
\text { an in-state or out-of-state prisoner or juvenile offender, as those terms are defined in section 18-101A, Idaho Code. } \\
\text { (2) It is a felony for any supervising officer, as that term is defined in section } 18 \text {-101A, Idaho Code, to knowingly } \\
\text { have sexual contact with any parolee or probationer, as those terms are defined in section 18-101A, Idaho Code, } \\
\text { who is not the person's spouse. } \\
\text { (3) For the purposes of this section "sexual contact" means sexual intercourse, genital-genital contact, manual-anal } \\
\text { contact, manual-genital contact, oral-genital contact, anal-genital contact or oral-anal contact, between persons of } \\
\text { the same or opposite sex. } \\
\text { (4) Any person found guilty of sexual contact with a prisoner or juvenile offender is punishable by imprisonment in } \\
\text { the state prison for a term not to exceed life. }\end{array}$ \\
\hline $\begin{array}{l}\text { Information Maintained in } \\
\text { Sex Offender Registry } \\
\text { (Idaho) }\end{array}$ & $\begin{array}{l}\text { I.C. } \$ 18-8307 \text { (West 2008) } \\
\text { (1) Registration shall consist of a form provided by the department and approved by the attorney general, which } \\
\text { shall be signed by the offender and shall require the following information about the offender: } \\
\text { (a) Name and all aliases which the person has used or under which the person has been known; } \\
\text { (b) A complete description of the person including the date of birth and social security number; } \\
\text { (c) Name of each offense enumerated in section 18-8304, Idaho Code, of which the person was convicted, } \\
\text { where each offense was committed, where the person was convicted of each offense, and the name under }\end{array}$ \\
\hline
\end{tabular}

** Denotes those states where sex offender registration is required for convictions under the staff sexual misconduct laws of the states. Staff and inmates could also be required to register as sex offenders if the offense were charged under other registrable offenses.

This publication is developed by the NIC/WCL Project on Addressing Prison Rape under NIC Cooperative Agreement 06S20GJJ1.

This is not to be posted or reproduced without permission from the authors.

American University, Washington College of Law

Current as of August 2009 


\section{Fifty State Survey of Adult Sex Offender Registration Requirements}

\section{NIC/WCL Project on Addressing Prison Rape}

\begin{tabular}{|c|c|}
\hline $\begin{array}{l}\text { Information Maintained in } \\
\text { Sex Offender Registry } \\
\text { Cont'd } \\
\text { (Idaho) }\end{array}$ & $\begin{array}{l}\text { which the person was convicted of each offense; } \\
\text { (d) The name and location of each hospital, jail or penal institution to which the person was committed for each } \\
\text { offense covered under this chapter; } \\
\text { (e) School or college enrollment; and } \\
\text { (f) Address or physical description of current residence and place of employment. }\end{array}$ \\
\hline $\begin{array}{l}\text { Community Notification } \\
\text { and Websites } \\
(\text { Idaho) }\end{array}$ & $\begin{array}{l}\text { I.C. } \$ 18-8323 \text { (West 2008) } \\
\text { (1): } \\
\text { - The department or sheriff shall provide public access to information contained in the central sexual offender } \\
\text { registry. } \\
\text { - The department shall promulgate rules defining the processes for providing information to the public and the } \\
\text { requirements for retention of inquiry records by the department and sheriff. } \\
\text { - The department may provide public access to the sex offender registry by means of the internet. } \\
\text { (2): The department and sheriff will respond to requests for sexual offender registry information within ten (10) } \\
\text { working days of receipt of the written request. } \\
\text { (a): } \\
\text { - Any person may inquire about a named individual by submitting an information request form obtained from the } \\
\text { department or sheriff. } \\
\text { - The department shall promulgate rules outlining the methods and means of submitting requests. } \\
\text { - Information required for inquiry shall include the individual's full name and address, or full name and date of } \\
\text { birth. } \\
\text { - The requester shall provide his full name, street address and driver's license or social security number. } \\
\text { (b): } \\
\text { - Any person may request a list of registered sexual offenders by geographic area, such as by county or by zip } \\
\text { code area, as determined by rule, by submitting an information request form obtained from the department or } \\
\text { sheriff. } \\
\text { - The requester shall provide his full name, street address and driver's license, social security number, or state }\end{array}$ \\
\hline
\end{tabular}

** Denotes those states where sex offender registration is required for convictions under the staff sexual misconduct laws of the states. Staff and 62 inmates could also be required to register as sex offenders if the offense were charged under other registrable offenses.

This publication is developed by the NIC/WCL Project on Addressing Prison Rape under NIC Cooperative Agreement 06S20GJJ1.

This is not to be posted or reproduced without permission from the authors.

American University, Washington College of Law

Current as of August 2009 


\section{Fifty State Survey of Adult Sex Offender Registration Requirements}

\section{NIC/WCL Project on Addressing Prison Rape}

\begin{tabular}{|c|c|}
\hline $\begin{array}{l}\text { Community Notification } \\
\text { and Websites Cont'd } \\
\text { (Idaho) }\end{array}$ & $\begin{array}{l}\text { identification number. } \\
\text { (c) Schools, organizations working with youth, women or other vulnerable populations may request a statewide } \\
\text { list or lists by geographic area within the state. }\end{array}$ \\
\hline
\end{tabular}

** Denotes those states where sex offender registration is required for convictions under the staff sexual misconduct laws of the states. Staff and inmates could also be required to register as sex offenders if the offense were charged under other registrable offenses.

This publication is developed by the NIC/WCL Project on Addressing Prison Rape under NIC Cooperative Agreement 06S20GJJ1.

This is not to be posted or reproduced without permission from the authors.

American University, Washington College of Law

Current as of August 2009 


\section{Fifty State Survey of Adult Sex Offender Registration Requirements}

\section{NIC/WCL Project on Addressing Prison Rape}

\begin{tabular}{|c|c|}
\hline $\begin{array}{l}\text { Duration of Registration } \\
\text { (Idaho) }\end{array}$ & $\begin{array}{l}\text { I.C. } \S 18-8302 \text { (West 2008) } \\
\text { Adult sex offenders must register for life. } \\
\text { I.C. } \S 18-810 \text { (West } 2008 \text { ) } \\
\text { (1) An adult sex offender who is not a repeat sex offender, aggravated sex offender or sexually violent predator may } \\
\text { petition for exemption from registration after } 10 \text { years. }\end{array}$ \\
\hline $\begin{array}{l}\text { Registrable Offenses } \\
\text { (Illinois) }\end{array}$ & $\begin{array}{l}\text { - } \quad \text { Child pornography - } 720 \text { ILL. COMP. STAT. ANN. 5/11-20.1 (West 2008). } \\
\text { - } \quad \text { Indecent solicitation of a child - 720 ILL. COMP. STAT. ANN. 5/11-6 (West 2008). } \\
\text { - } \quad \text { Sexual exploitation of a child - 720 ILL. COMP. STAT. ANN. 5/11-9.1 (West 2008). } \\
\text { - } \quad \text { Custodial sexual misconduct - 720 ILL. COMP. STAT. ANN. 5/11-9.2 (West 2008). } \\
\text { - } \quad \text { Patronizing a juvenile prostitute - 720 ILL. COMP. STAT. ANN. 5/11-18.1 (West 2008). } \\
\text { - } \quad \text { Keeping a place of juvenile prostitution - 720 ILL. COMP. STAT. ANN. 5/11-17.1 (West 2008). } \\
\text { - } \quad \text { Juvenile Pimping - } 720 \text { ILL. COMP. STAT. ANN. 5/11-19.1 (West 2008). } \\
\text { - } \quad \text { Exploitation of a child - 720 ILL. COMP. STAT. ANN. 5/11-19.2 (West 2008). } \\
\text { - } \quad \text { Aggravated Criminal Sexual Assault - 720 ILL. COMP. STAT. ANN. 5/12-14 (West 2008). } \\
\text { - } \quad \text { Predatory criminal sexual assault of a child - 720 ILL. COMP. STAT. ANN. 5/12-14.1 (West 2008). } \\
\text { - } \quad \text { Criminal sexual abuse - } 720 \text { ILL. COMP. STAT. ANN. 5/12-15 (West 2008). } \\
\text { - } \quad \text { Ritualized abuse of a child -720 ILL. COMP. STAT. ANN. § 18-1506A (West 2008). } \\
\text { - } \quad \text { The attempt to commit any of the crimes listed above. } \\
\text { - Kidnapping (of person under the age of 18) - 720 ILL. COMP. STAT. ANN. 5/10-1 (West 2008). }\end{array}$ \\
\hline
\end{tabular}

** Denotes those states where sex offender registration is required for convictions under the staff sexual misconduct laws of the states. Staff and inmates could also be required to register as sex offenders if the offense were charged under other registrable offenses.

This publication is developed by the NIC/WCL Project on Addressing Prison Rape under NIC Cooperative Agreement 06S20GJJ1.

This is not to be posted or reproduced without permission from the authors.

American University, Washington College of Law

Current as of August 2009 


\section{Fifty State Survey of Adult Sex Offender Registration Requirements}

\section{NIC/WCL Project on Addressing Prison Rape}

\begin{tabular}{|c|c|}
\hline $\begin{array}{l}\text { Registrable Offenses Cont'd } \\
\text { (Illinois) }\end{array}$ & $\begin{array}{l}\text { - Aggravated kidnapping (of person under the age of 18) - } 720 \text { ILL. COMP. STAT. ANN. 5/10-2 (West } \\
\text { 2008). } \\
\text { - Unlawful restraining (of person under the age of 18) - } 720 \text { ILL. COMP. STAT. ANN. 5/10-3 (West 2008). } \\
\text { - Aggravated unlawful restraint (of person under the age of 18) - } 720 \text { ILL. COMP. STAT. ANN. 5/10-3.1 } \\
\text { (West 2008). } \\
\text { - First degree murder (of person under the age of } 18 \text { by a defendant aged } 17 \text { or older) - } 720 \text { ILL. COMP. } \\
\text { STAT. ANN. 5/9-1 (West 2008). } \\
\text { - Sexual relations within families - } 720 \text { ILL. COMP. STAT. ANN. 5/11-11 (West 2008). } \\
\text { - Child abduction (committed by luring or attempting to lure a child under the age of 16 without the consent } \\
\text { of the parent of lawful custodian for unlawful purposes) - 720 ILL. COMP. STAT. ANN. 5/10-5(10)(b) } \\
\text { (West 2008). } \\
\text { - Forcible detention (of person under the age of } 18 \text { ) - } 720 \text { ILL. COMP. STAT. ANN. 5/10-4 (West 2008). } \\
\text { - Indecent solicitation of an adult - } 720 \text { ILL. COMP. STAT. ANN. 5/11-6.5 (West 2008). } \\
\text { Soliciting for a prostitute (if the victim is under } 18 \text { years of age) - 720 ILL. COMP. STAT. ANN. 5/11-15 } \\
\text { (West 2008). } \\
\text { Pandering (if the victim is under } 18 \text { years of age) - } 720 \text { ILL. COMP. STAT. ANN. 5/11-16 (West 2008). } \\
\text { - Patronizing a prostitute (if the victim is under } 18 \text { years of age) - 720 ILL. COMP. STAT. ANN. 5/11-18 } \\
\text { - PWest 2008). } \\
\text { - Pimping ((if the victim is under } 18 \text { years of age) -720 ILL. COMP. STAT. ANN. 5/11-19 (West 2008). } \\
\text { - Public indecency (3rd or subsequent conviction) - } 720 \text { ILL. COMP. STAT. ANN. 5/11-9 (West 2008). } \\
\text { - Ormitting sexual abuse - 720 ILL. COMP. STAT. ANN. 150/5.1 (West 2008). } \\
\text { Or the attempt to commit any of the above crimes. } \\
\text { a foreign country that is substantially equivalent to any offense listed above. }\end{array}$ \\
\hline $\begin{array}{l}\text { Sex Offender Registration } \\
\text { Required for Staff Sexual } \\
\text { Misconduct? } \\
\text { (Illinois) }\end{array}$ & $\begin{array}{l}\text { YES. } \\
720 \text { I.L.C.S. 5/11-9.2 (WEST 2008) } \\
\text { Custodial Sexual Misconduct. }\end{array}$ \\
\hline
\end{tabular}

** Denotes those states where sex offender registration is required for convictions under the staff sexual misconduct laws of the states. Staff and inmates could also be required to register as sex offenders if the offense were charged under other registrable offenses.

This publication is developed by the NIC/WCL Project on Addressing Prison Rape under NIC Cooperative Agreement 06S20GJJ1.

This is not to be posted or reproduced without permission from the authors.

American University, Washington College of Law

Current as of August 2009 


\section{Fifty State Survey of Adult Sex Offender Registration Requirements}

\section{NIC/WCL Project on Addressing Prison Rape}

\begin{tabular}{|c|c|}
\hline $\begin{array}{l}\text { Sex Offender Registration } \\
\text { Required for Staff Sexual } \\
\text { Misconduct? Cont'd } \\
\text { (Illinois) }\end{array}$ & 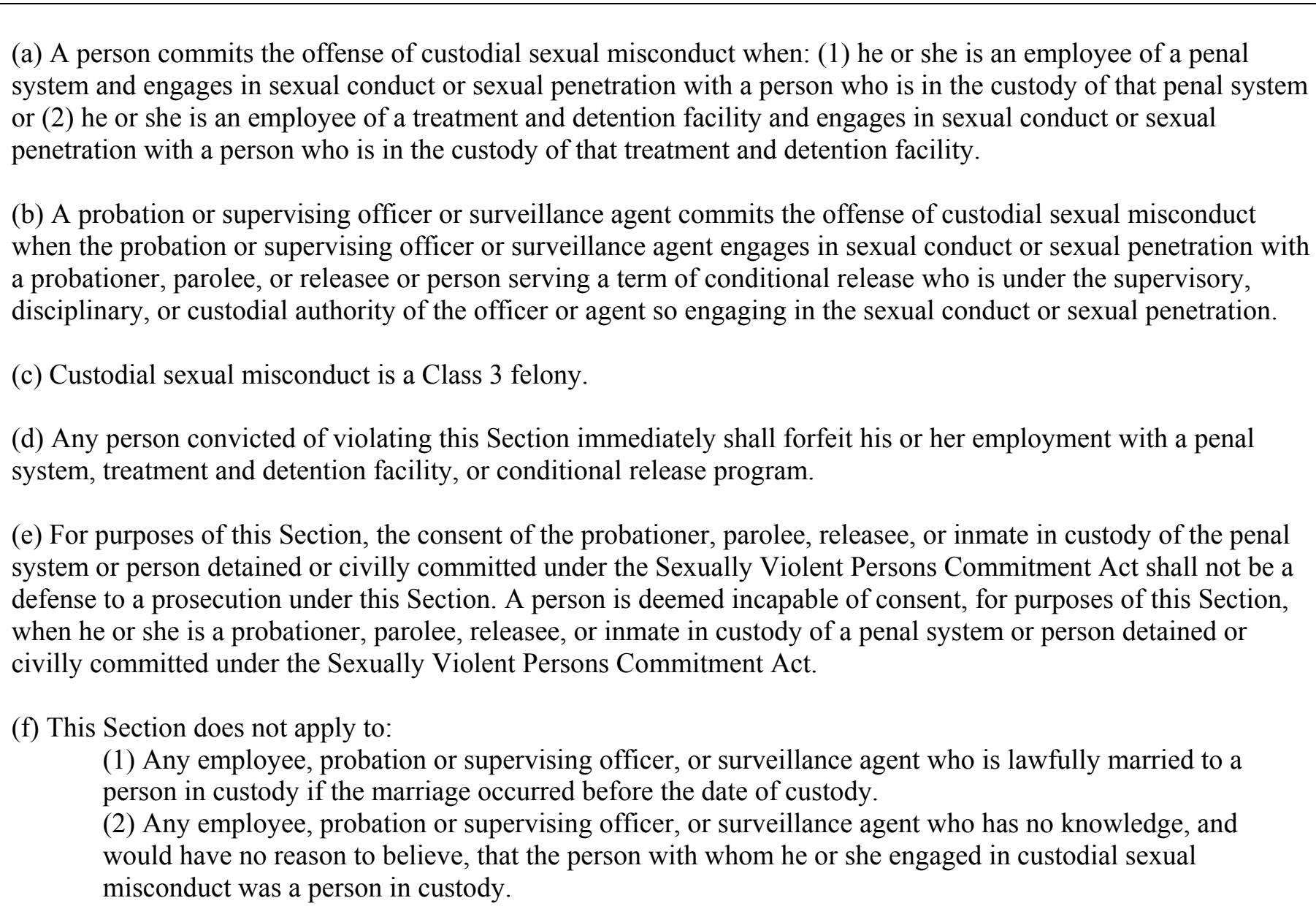 \\
\hline
\end{tabular}

** Denotes those states where sex offender registration is required for convictions under the staff sexual misconduct laws of the states. Staff and inmates could also be required to register as sex offenders if the offense were charged under other registrable offenses.

This publication is developed by the NIC/WCL Project on Addressing Prison Rape under NIC Cooperative Agreement 06S20GJJ1.

This is not to be posted or reproduced without permission from the authors.

American University, Washington College of Law

Current as of August 2009 


\section{Fifty State Survey of Adult Sex Offender Registration Requirements}

\section{NIC/WCL Project on Addressing Prison Rape}

\begin{tabular}{|c|c|}
\hline $\begin{array}{l}\text { Information Maintained in } \\
\text { Sex Offender Registry } \\
\text { (Illinois) }\end{array}$ & $\begin{array}{l}730 \text { I.L.C.S. } 150 / 3 \text { (West 2008) } \\
\text { Duty to register. } \\
\text { (a) } \\
\text { - name } \\
\text { - current photograph } \\
\text { - current address } \\
\text { - current place of employment and employer's telephone number } \\
\text { - school attended }\end{array}$ \\
\hline $\begin{array}{l}\text { Community Notification } \\
\text { and Websites } \\
\text { (Illinois) }\end{array}$ & $\begin{array}{l}\text { 730 I.L.C.S. 154/95 (West 2008) } \\
\text { (a): The sheriff of the county, except Cook County, shall disclose to the following the: } \\
\text { - name } \\
\text { - address } \\
\text { - date of birth } \\
\text { - place of employment } \\
\text { - school attended and } \\
\text { - offense or adjudication of all sex offenders required to register under the Sex Offender Registration Act: } \\
\text { o the boards of institutions of higher education or other appropriate administrative offices of each non-public } \\
\text { institution of higher education located in the county where the sex offender is required to register, resides, is } \\
\text { employed, or is attending an institution of higher education; and } \\
\text { o school boards of public school districts and the principal or other appropriate administrative officer of each } \\
\text { nonpublic school located in the county where the sex offender is required to register or is employed; and } \\
\text { o child care facilities located in the county where the sex offender is required to register or is employed. } \\
\text { (a-2): The sheriff of Cook County shall disclose to the following the } \\
\text { - name, } \\
\text { - address, }\end{array}$ \\
\hline
\end{tabular}

** Denotes those states where sex offender registration is required for convictions under the staff sexual misconduct laws of the states. Staff and inmates could also be required to register as sex offenders if the offense were charged under other registrable offenses.

This publication is developed by the NIC/WCL Project on Addressing Prison Rape under NIC Cooperative Agreement 06S20GJJ1.

This is not to be posted or reproduced without permission from the authors.

American University, Washington College of Law

Current as of August 2009 


\section{Fifty State Survey of Adult Sex Offender Registration Requirements}

\section{NIC/WCL Project on Addressing Prison Rape}

\begin{tabular}{|c|c|}
\hline $\begin{array}{l}\text { Community Notification } \\
\text { and Websites Cont'd } \\
\text { (Illinois) }\end{array}$ & $\begin{array}{l}\text { - date of birth, } \\
\text { - place of employment, } \\
\text { - school attended, and } \\
\text { - offense or adjudication of all sex offenders required to register under the Sex Offender Registration Act: } \\
\text { o school boards of public school districts and the principal or other appropriate administrative officer of each } \\
\text { nonpublic school located within the region of Cook County, as those public school districts and nonpublic } \\
\text { schools are identified in LEADS, other than the City of Chicago, where the sex offender is required to } \\
\text { register or is employed; and } \\
\text { o child care facilities located within the region of Cook County, as those child care facilities are identified in } \\
\text { LEADS, other than the City of Chicago, where the sex offender is required to register or is employed; and } \\
\text { o the boards of institutions of higher education or other appropriate administrative offices of each non-public } \\
\text { institution of higher education located in the county, other than the City of Chicago, where the sex offender } \\
\text { is required to register, resides, is employed, or attending an institution of higher education. } \\
\text { (a-3): The Chicago Police Department shall disclose to the following: } \\
\text { - name, } \\
\text { - address, } \\
\text { - date of birth, } \\
\text { - place of employment, } \\
\text { - school attended, and } \\
\text { - offense or adjudication of all sex offenders required to register under the Sex Offender Registration Act: } \\
\text { o school boards of public school districts and the principal or other appropriate administrative officer of each } \\
\text { nonpublic school located in the police district where the sex offender is required to register or is employed if } \\
\text { the offender is required to register or is employed in the City of Chicago; and } \\
\text { o child care facilities located in the police district where the sex offender is required to register or is employed if } \\
\text { the offender is required to register or is employed in the City of Chicago; and } \\
\text { o the boards of institutions of higher education or other appropriate administrative offices of each non-public } \\
\text { institution of higher education located in the police district where the sex offender is required to register, } \\
\text { resides, is employed, or attending an institution of higher education in the City of Chicago. }\end{array}$ \\
\hline
\end{tabular}

** Denotes those states where sex offender registration is required for convictions under the staff sexual misconduct laws of the states. Staff and inmates could also be required to register as sex offenders if the offense were charged under other registrable offenses.

This publication is developed by the NIC/WCL Project on Addressing Prison Rape under NIC Cooperative Agreement 06S20GJJ1.

This is not to be posted or reproduced without permission from the authors.

American University, Washington College of Law

Current as of August 2009 


\section{Fifty State Survey of Adult Sex Offender Registration Requirements}

\section{NIC/WCL Project on Addressing Prison Rape}

\begin{tabular}{|c|c|}
\hline $\begin{array}{l}\text { Community Notification } \\
\text { and Websites Cont'd } \\
\text { (Illinois) }\end{array}$ & 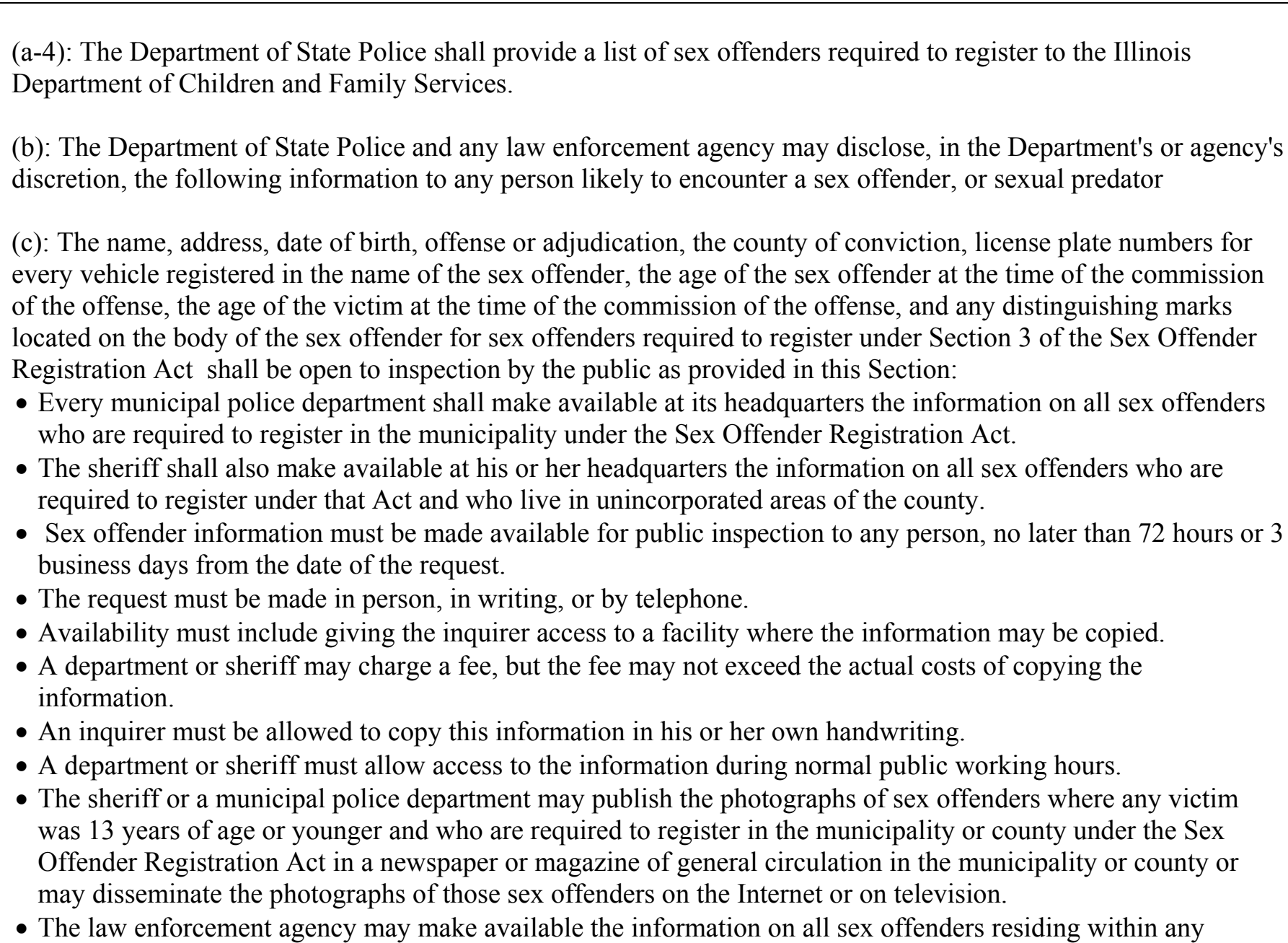 \\
\hline
\end{tabular}

** Denotes those states where sex offender registration is required for convictions under the staff sexual misconduct laws of the states. Staff and inmates could also be required to register as sex offenders if the offense were charged under other registrable offenses.

This publication is developed by the NIC/WCL Project on Addressing Prison Rape under NIC Cooperative Agreement 06S20GJJ1.

This is not to be posted or reproduced without permission from the authors.

American University, Washington College of Law

Current as of August 2009 


\section{Fifty State Survey of Adult Sex Offender Registration Requirements}

\section{NIC/WCL Project on Addressing Prison Rape}

\begin{tabular}{|c|c|}
\hline $\begin{array}{l}\text { Community Notification } \\
\text { and Websites Cont'd } \\
\text { (Illinois) }\end{array}$ & $\begin{array}{l}\text { county. } \\
\text { (d): The Department of State Police and any law enforcement agency having jurisdiction may, in the } \\
\text { Department's or agency's discretion, place the information specified in subsection (b) on the Internet or in other } \\
\text { media. } \\
730 \text { ILL. COMP. STAT. ANN. 150/115 (West 2008). } \\
\text { (b): } \\
\text { - The Department of State Police must make the information contained in the Statewide Sex Offender Database } \\
\text { accessible on the Internet by means of a hyperlink labeled "Sex Offender Information" on the Department's } \\
\text { World Wide Web home page. } \\
\text { The Department must make the information contained in the Statewide Sex Offender Database searchable via a } \\
\text { mapping system which identifies registered sex offenders living within } 5 \text { miles of an identified address. }\end{array}$ \\
\hline $\begin{array}{l}\text { Limitations on Residency or } \\
\text { Employment } \\
\text { (Illinois) }\end{array}$ & $\begin{array}{l}720 \text { I.L.C.S. 5/11-9.3 (West 2008) } \\
\text { (a): Unless they are the parent or guardian of a minor on the premises, child sex offenders may not knowingly be } \\
\text { present: } \\
\text { - in any school building } \\
\text { - on real property } \\
\text { comprising any school } \\
\text { in any conveyance owned, leased, or contracted by a school to transport students to or from school. } \\
\text { (b): A child sex offender may not knowingly loiter within } 500 \text { feet of a school building while persons under the age } \\
\text { of } 18 \text { are present in the building unless they are the parent or guardian of a student attending the school. } \\
730 \text { ILL. COMP. STAT. ANN. } 150 / 8 \text { (West 2008). }\end{array}$ \\
\hline
\end{tabular}

** Denotes those states where sex offender registration is required for convictions under the staff sexual misconduct laws of the states. Staff and inmates could also be required to register as sex offenders if the offense were charged under other registrable offenses.

This publication is developed by the NIC/WCL Project on Addressing Prison Rape under NIC Cooperative Agreement 06S20GJJ1.

This is not to be posted or reproduced without permission from the authors.

American University, Washington College of Law

Current as of August 2009 


\section{Fifty State Survey of Adult Sex Offender Registration Requirements}

\section{NIC/WCL Project on Addressing Prison Rape}

\begin{tabular}{|c|c|}
\hline $\begin{array}{l}\text { Limitations on Residency or } \\
\text { Employment Cont'd } \\
\text { (Illinois) }\end{array}$ & $\begin{array}{l}\text { A child sex offender may not reside within } 500 \text { feet of a school, park, or playground. The offender may also not } \\
\text { reside within } 500 \text { feet of a facility providing services directed exclusively toward persons under } 18 \text { years of age } \\
\text { unless the sex offender meets specified statutory exemptions. }\end{array}$ \\
\hline $\begin{array}{l}\text { Duration of Registration } \\
\text { (Illinois) }\end{array}$ & $\begin{array}{l}730 \text { I.L.C.S. } 150 / 7 \text { (West 2008) } \\
\text { Life for persons determined to be a sexually violent person or sexual predator. } \\
\text { All other sex offenders must register for } 10 \text { years. }\end{array}$ \\
\hline & INDIANA \\
\hline $\begin{array}{l}\text { Registrable Offenses } \\
\text { (Indiana) }\end{array}$ & 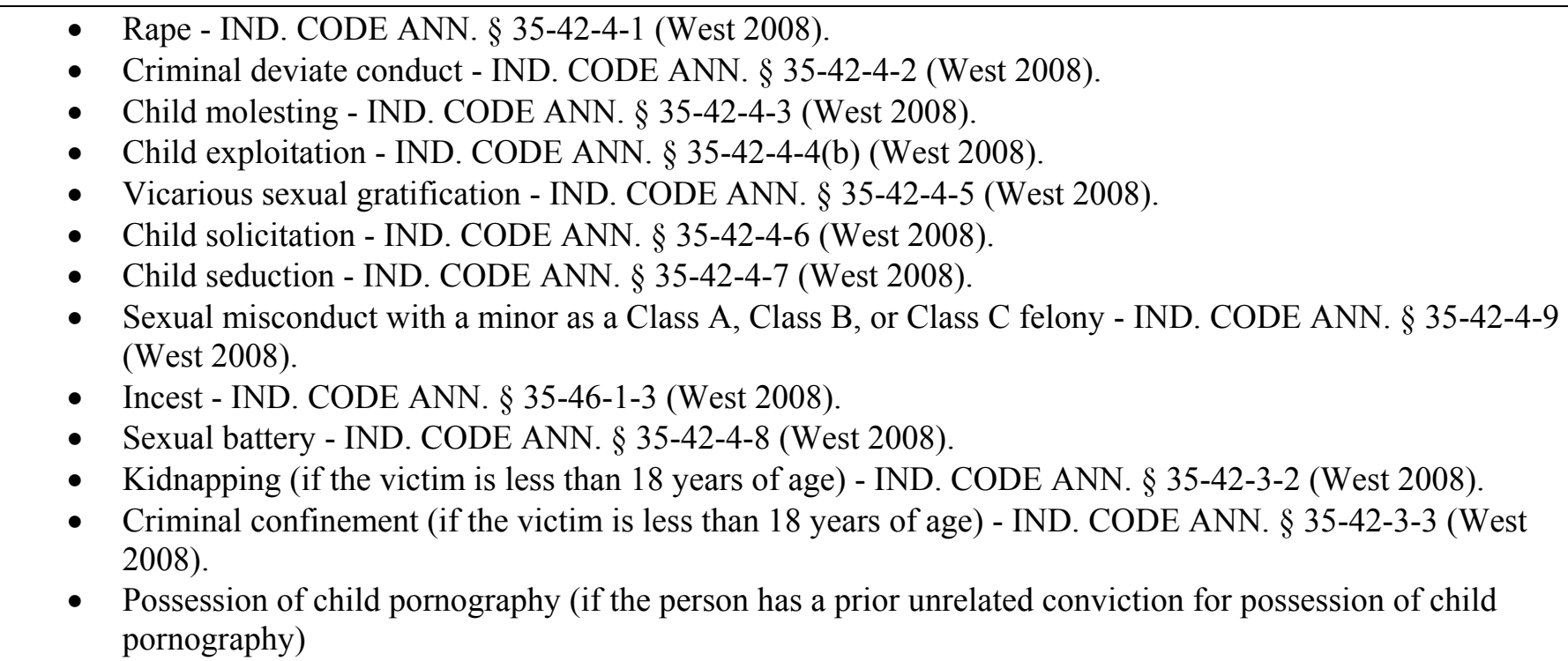 \\
\hline
\end{tabular}

** Denotes those states where sex offender registration is required for convictions under the staff sexual misconduct laws of the states. Staff and inmates could also be required to register as sex offenders if the offense were charged under other registrable offenses.

This publication is developed by the NIC/WCL Project on Addressing Prison Rape under NIC Cooperative Agreement 06S20GJJ1.

This is not to be posted or reproduced without permission from the authors.

American University, Washington College of Law

Current as of August 2009 


\section{Fifty State Survey of Adult Sex Offender Registration Requirements}

\section{NIC/WCL Project on Addressing Prison Rape}

\begin{tabular}{|c|c|}
\hline $\begin{array}{l}\text { Registrable Offenses Cont'd } \\
\text { (Indiana) }\end{array}$ & $\begin{array}{l}\text { - IND. CODE ANN. } § 35-42-4-4 \text { (West 2008). } \\
\text { Attempt or conspiracy to commit a crime listed above. } \\
\text { A crime under the laws of another jurisdiction, including a military court, that is substantially equivalent to any of } \\
\text { the offenses listed. }\end{array}$ \\
\hline $\begin{array}{l}\text { Sex Offender Registration } \\
\text { Required for Staff Sexual } \\
\text { Misconduct? } \\
\text { (Indiana) }\end{array}$ & NO \\
\hline $\begin{array}{l}\text { Information Maintained in } \\
\text { Sex Offender Registry } \\
\text { (Indiana) }\end{array}$ & $\begin{array}{l}\text { IC } \$ 11-8-8-8 \text { (West 2008) } \\
\text { Sec. 8. (a) The registration required under this chapter must include the following information: } \\
\text { (1) The sex or violent offender's full name, alias, any name by which the sex or violent offender was previously } \\
\text { known, date of birth, sex, race, height, weight, hair color, eye color, any scars, marks, or tattoos, Social Security } \\
\text { number, driver's license number or state identification card number, vehicle description and vehicle plate number } \\
\text { for any vehicle the sex or violent offender owns or operates on a regular basis, principal residence address, other } \\
\text { address where the sex or violent offender spends more than seven ( } 7 \text { ) nights in a fourteen (14) day period, and } \\
\text { mailing address, if different from the sex or violent offender's principal residence address. } \\
\text { (2) A description of the offense for which the sex or violent offender was convicted, the date of conviction, the } \\
\text { county of the conviction, the cause number of the conviction, and the sentence imposed, if applicable. } \\
\text { (3) If the person is required to register under section } 7(\text { a)(2) or } 7(\text { a) (3) of this chapter, the name and address of each } \\
\text { of the sex or violent offender's employers in Indiana, the name and address of each campus or location where the } \\
\text { sex or violent offender is enrolled in school in Indiana, and the address where the sex or violent offender stays or } \\
\text { intends to stay while in Indiana. }\end{array}$ \\
\hline
\end{tabular}

** Denotes those states where sex offender registration is required for convictions under the staff sexual misconduct laws of the states. Staff and inmates could also be required to register as sex offenders if the offense were charged under other registrable offenses.

This publication is developed by the NIC/WCL Project on Addressing Prison Rape under NIC Cooperative Agreement 06S20GJJ1.

This is not to be posted or reproduced without permission from the authors.

American University, Washington College of Law

Current as of August 2009 


\section{Fifty State Survey of Adult Sex Offender Registration Requirements}

\section{NIC/WCL Project on Addressing Prison Rape}

\begin{tabular}{|c|c|}
\hline $\begin{array}{l}\text { Information Maintained in } \\
\text { Sex Offender Registry } \\
\text { Cont'd } \\
\text { (Indiana) }\end{array}$ & $\begin{array}{l}\text { (4) A recent photograph of the sex or violent offender. } \\
\text { (5) If the sex or violent offender is a sexually violent predator, that the sex or violent offender is a sexually violent } \\
\text { predator. } \\
\text { (6) If the sex or violent offender is required to register for life, that the sex or violent offender is required to register } \\
\text { for life. } \\
\text { (7) Any electronic mail address, instant messaging username, electronic chat room username, or social networking } \\
\text { web site username that the sex or violent offender uses or intends to use. } \\
\text { (8) Any other information required by the department. }\end{array}$ \\
\hline $\begin{array}{l}\text { Community Notification } \\
\text { and Websites } \\
\text { (Indiana) }\end{array}$ & $\begin{array}{l}\text { IC } § 11-8-8-7 \text { (West 2008) } \\
\text { (i): } \\
\text { - The local law enforcement authority with whom a sex offender registers under this section shall make and } \\
\text { publish a photograph of the sex offender on the Indiana sex offender registry web site. } \\
\text { - The local law enforcement authority shall make a photograph of the sex offender at least once per year. }\end{array}$ \\
\hline $\begin{array}{l}\text { Limitations on Residency or } \\
\text { Employment } \\
\text { (Indiana) }\end{array}$ & None. \\
\hline $\begin{array}{l}\text { Duration of Registration } \\
\text { (Indiana) }\end{array}$ & $\begin{array}{l}\text { IC } § 11-8-8-19 \text { (West 2008) } \\
\text { (a): } 10 \text { years for sex offenders not subject to lifetime registration. } \\
\text { (b): Life for sexually violent predators. }\end{array}$ \\
\hline
\end{tabular}

** Denotes those states where sex offender registration is required for convictions under the staff sexual misconduct laws of the states. Staff and inmates could also be required to register as sex offenders if the offense were charged under other registrable offenses.

This publication is developed by the NIC/WCL Project on Addressing Prison Rape under NIC Cooperative Agreement 06S20GJJ1.

This is not to be posted or reproduced without permission from the authors.

American University, Washington College of Law

Current as of August 2009 


\section{Fifty State Survey of Adult Sex Offender Registration Requirements}

\section{NIC/WCL Project on Addressing Prison Rape}

\begin{tabular}{|c|c|}
\hline $\begin{array}{l}\text { Duration of Registration } \\
\text { Cont'd } \\
\text { (Indiana) }\end{array}$ & $\begin{array}{l}\text { (c): Life for persons over the age of } 18 \text { who committed a sex offense against a victim less than } 12 \text { years of age. } \\
\text { (d): Life for sex offenders who caused serious bodily injury or death, used force or threat of force or rendered the } \\
\text { victim unconscious or otherwise unable to give voluntary consent. } \\
\text { (e): Life for offenders convicted of } 2 \text { or more unrelated sex offenses. }\end{array}$ \\
\hline & IOWA** \\
\hline $\begin{array}{l}\text { Registrable Offenses } \\
\text { (Iowa) }\end{array}$ & 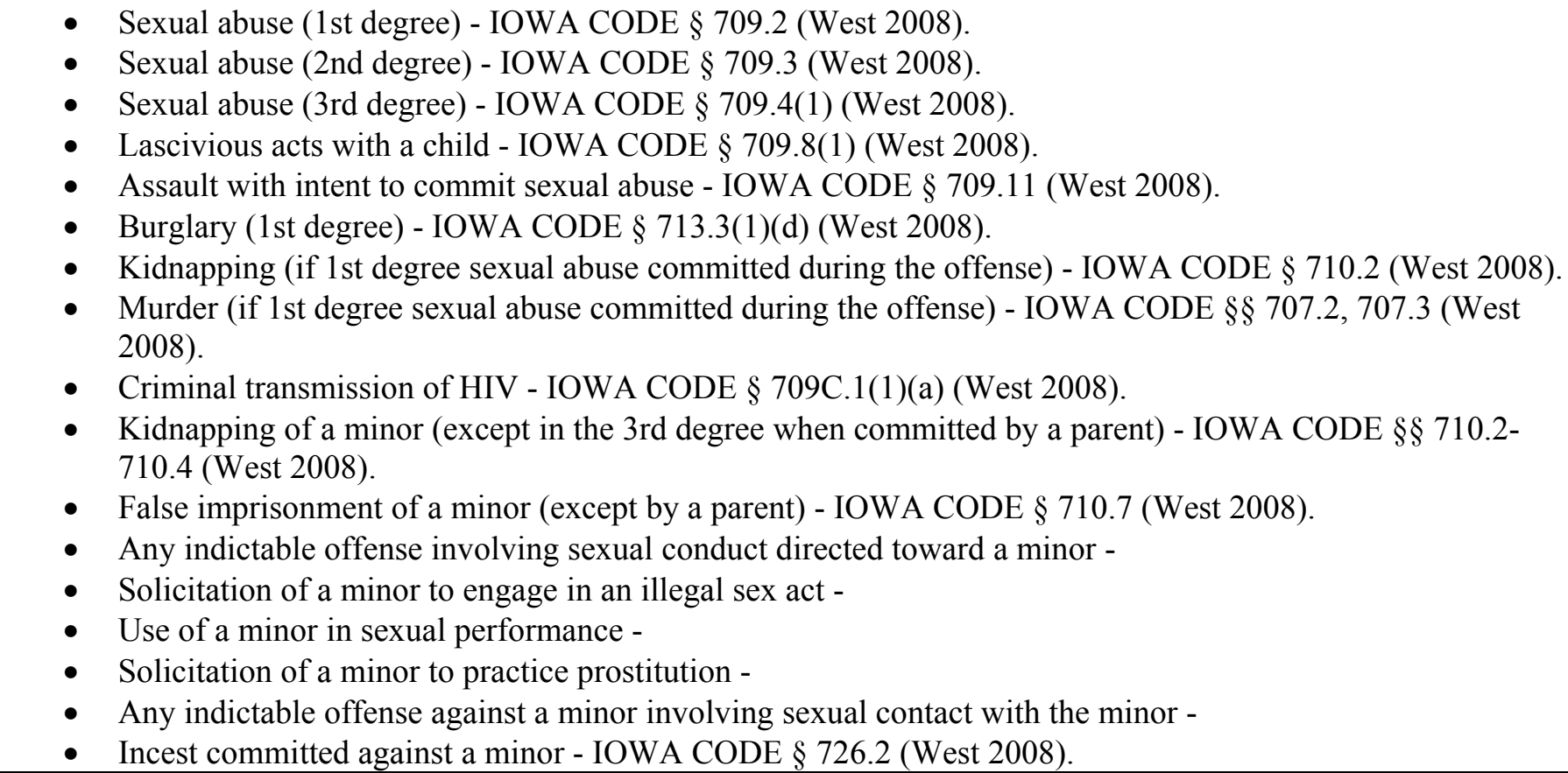 \\
\hline
\end{tabular}

** Denotes those states where sex offender registration is required for convictions under the staff sexual misconduct laws of the states. Staff and inmates could also be required to register as sex offenders if the offense were charged under other registrable offenses.

This publication is developed by the NIC/WCL Project on Addressing Prison Rape under NIC Cooperative Agreement 06S20GJJ1.

This is not to be posted or reproduced without permission from the authors.

American University, Washington College of Law

Current as of August 2009 


\section{Fifty State Survey of Adult Sex Offender Registration Requirements}

\section{NIC/WCL Project on Addressing Prison Rape}

\begin{tabular}{|c|c|}
\hline $\begin{array}{l}\text { Registrable Offenses Cont'd } \\
\text { (Iowa) }\end{array}$ & $\begin{array}{l}\text { - Dissemination and exhibition of obscene material to minors - IOWA CODE } \S 728.2 \text { (West 2008). } \\
\text { - } \text { - Sdmitting minors to premises where obscene material is exhibited - IOWA CODE } \S 728.3 \text { (West 2008). } \\
\text { - Sexual exploitation of a minor - IOWA CODE } \S 728.12 \text { (West 2008). } \\
\text { - Enticing away a minor - IOWA CODE } \S 710.10(1) \text { (West 2008). } \\
\text { - Telephone dissemination of obscene materials - IOWA CODE } \S 728.15 \text { (West 2008). } \\
\text { - Rental or sale of hard-core pornography - IOWA CODE } \S 728.4 \text { (West 2008). } \\
\text { - Indecent exposure - IOWA CODE } \S 709.9 \text { (West 2008). } \\
\text { - Incest committed against a dependent adult (as defined in 235B.2) - IOWA CODE } \S 726.2 \text { (West 2008). } \\
\text { - Sexual misconduct with offenders - IOWA CODE } \S 709.16 \text { (West 2008). } \\
\text { - Murder, attempted murder, kidnapping, burglary or manslaughter if the offense involves sexual abuse or } \\
\text { - } \text { attempted sexual abuse. } \\
\text { Any attempt to commit one of the offenses listed above. }\end{array}$ \\
\hline $\begin{array}{l}\text { Sex Offender Registration } \\
\text { Required for Staff Sexual } \\
\text { Misconduct? } \\
\text { (Iowa) }\end{array}$ & $\begin{array}{l}\text { YES. } \\
\text { I.C.A. } \S 709.16 \text { (West 2008) } \\
\text { 1. An officer, employee, contractor, vendor, volunteer, or agent of the department of corrections, or an officer, } \\
\text { employee, or agent of a judicial district department of correctional services, who engages in a sex act with an } \\
\text { individual committed to the custody of the department of corrections or a judicial district department of correctional } \\
\text { services commits an aggravated misdemeanor. } \\
\text { 2. An officer, employee, contractor, vendor, volunteer, or agent of a juvenile placement facility who engages in a } \\
\text { sex act with a juvenile placed at such facility commits an aggravated misdemeanor. } \\
\text { I.C.A. } \S 692 \text { A.2 (West 2008) }\end{array}$ \\
\hline
\end{tabular}

** Denotes those states where sex offender registration is required for convictions under the staff sexual misconduct laws of the states. Staff and inmates could also be required to register as sex offenders if the offense were charged under other registrable offenses.

This publication is developed by the NIC/WCL Project on Addressing Prison Rape under NIC Cooperative Agreement 06S20GJJ1.

This is not to be posted or reproduced without permission from the authors.

American University, Washington College of Law

Current as of August 2009 


\section{Fifty State Survey of Adult Sex Offender Registration Requirements}

\section{NIC/WCL Project on Addressing Prison Rape}

\begin{tabular}{|c|c|}
\hline $\begin{array}{l}\text { Sex Offender Registration } \\
\text { Required for Staff Sexual } \\
\text { Misconduct? Cont'd } \\
\text { (Iowa) }\end{array}$ & $\begin{array}{l}\text { Persons required to register } \\
\text { 1. A person who has been convicted of a criminal offense against a minor, an aggravated offense, sexual } \\
\text { exploitation, an other relevant offense, or a sexually violent offense in this state or in another state, or in a federal, } \\
\text { military, tribal, or foreign court, or a person required to register in another state under the state's sex offender } \\
\text { registry, shall register as provided in this chapter. }\end{array}$ \\
\hline $\begin{array}{l}\text { Information Maintained in } \\
\text { Sex Offender Registry } \\
\text { (Iowa) }\end{array}$ & $\begin{array}{l}\text { I.C.A. } § 692 A .5 \text { (West 2008) } \\
\text { (1)(a) } \\
\text { - name } \\
\text { - social security number } \\
\text { - date of birth } \\
\text { - current address } \\
\text { - telephone number } \\
\text { - fingerprints } \\
\text { - photograph } \\
\text { - identifying factors (sexually violent predators only) } \\
\text { - anticipated future places of residence (sexually violent predators only) } \\
\text { - offense history (sexually violent predators only) } \\
\text { - documentation of treatment received for mental abnormality or personality disorder (sexually violent predators } \\
\text { only) }\end{array}$ \\
\hline $\begin{array}{l}\text { Community Notification } \\
\text { and Websites } \\
\text { (Iowa) }\end{array}$ & $\begin{array}{l}\text { I.C.A. } \S 692 \mathrm{~A} .13 \text { (West 2008) } \\
\text { 1. The department may provide relevant information from the sex offender registry to the following: } \\
\text { a. A criminal or juvenile justice agency, an agency of the state, any sex offender registry of another state, or }\end{array}$ \\
\hline
\end{tabular}

** Denotes those states where sex offender registration is required for convictions under the staff sexual misconduct laws of the states. Staff and inmates could also be required to register as sex offenders if the offense were charged under other registrable offenses.

This publication is developed by the NIC/WCL Project on Addressing Prison Rape under NIC Cooperative Agreement 06S20GJJ1.

This is not to be posted or reproduced without permission from the authors.

American University, Washington College of Law

Current as of August 2009 


\section{Fifty State Survey of Adult Sex Offender Registration Requirements}

\section{NIC/WCL Project on Addressing Prison Rape}

\begin{tabular}{|c|c|}
\hline $\begin{array}{l}\text { Community Notification } \\
\text { and Websites Cont'd } \\
(\text { Iowa) }\end{array}$ & $\begin{array}{l}\text { the federal government. } \\
\text { b. The general public through the sex offender registry's web page } \\
\text { c. The single contact repository. } \\
\text { 2. A criminal or juvenile justice agency may provide relevant information from the sex offender registry to the } \\
\text { following: } \\
\text { a. A criminal or juvenile justice agency, an agency of the state, or any sex offender registry of another state, or } \\
\text { the federal government. } \\
\text { b. The general public, including public and private agencies, organizations, public places, child care facilities, } \\
\text { religious and youth organizations, neighbors, neighborhood associations, community meetings, and } \\
\text { employers. Registry information may be distributed to the public through printed materials, visual or audio } \\
\text { press releases, radio communications, or through a criminal or juvenile justice agency's web page. } \\
\text { 3. When a person required to register under this chapter moves into a school district or moves within a school } \\
\text { district, the county sheriff of the county of the person's new residence shall provide relevant information from the } \\
\text { sex offender registry to the administrative office of the school district in which the person required to register } \\
\text { resides, and shall also provide relevant information to any private school near the person's residence. } \\
\text { 4. Any member of the public may contact a county sheriffs office or police department to request relevant } \\
\text { information from the registry regarding a specific person required to register under this chapter. } \\
\text { 5. A county sheriff shall also provide to any person upon request access to a list of all registrants in that county. }\end{array}$ \\
\hline $\begin{array}{l}\text { Limitations on Residency or } \\
\text { Employment } \\
\text { (Iowa) }\end{array}$ & $\begin{array}{l}\text { I.C.A. } \$ \text { 692A.2A (West 2008) } \\
\text { 1.5 Construction and application: } \\
\text { Any person who has committed a criminal offense against a minor, or aggravated offense, sexually violent } \\
\text { offense, or other relevant offense that involves a minor may not reside within } 2000 \text { feet of an elementary or } \\
\text { secondary school or child care facility. }\end{array}$ \\
\hline
\end{tabular}

** Denotes those states where sex offender registration is required for convictions under the staff sexual misconduct laws of the states. Staff and inmates could also be required to register as sex offenders if the offense were charged under other registrable offenses.

This publication is developed by the NIC/WCL Project on Addressing Prison Rape under NIC Cooperative Agreement 06S20GJJ1.

This is not to be posted or reproduced without permission from the authors.

American University, Washington College of Law

Current as of August 2009 


\section{Fifty State Survey of Adult Sex Offender Registration Requirements}

\section{NIC/WCL Project on Addressing Prison Rape}

\begin{tabular}{|c|c|}
\hline $\begin{array}{l}\text { Limitations on Residency or } \\
\text { Employment Cont'd } \\
\text { (Iowa) }\end{array}$ & $\begin{array}{l}\text { A sex offender who resided within } 2000 \text { feet of a school prior to July 1, } 2002 \text { is not required to move or sell } \\
\text { their residence. }\end{array}$ \\
\hline \multicolumn{2}{|r|}{ KANSAS ${ }^{* *}$} \\
\hline $\begin{array}{l}\text { Registrable Offenses } \\
\text { (Kansas) }\end{array}$ & 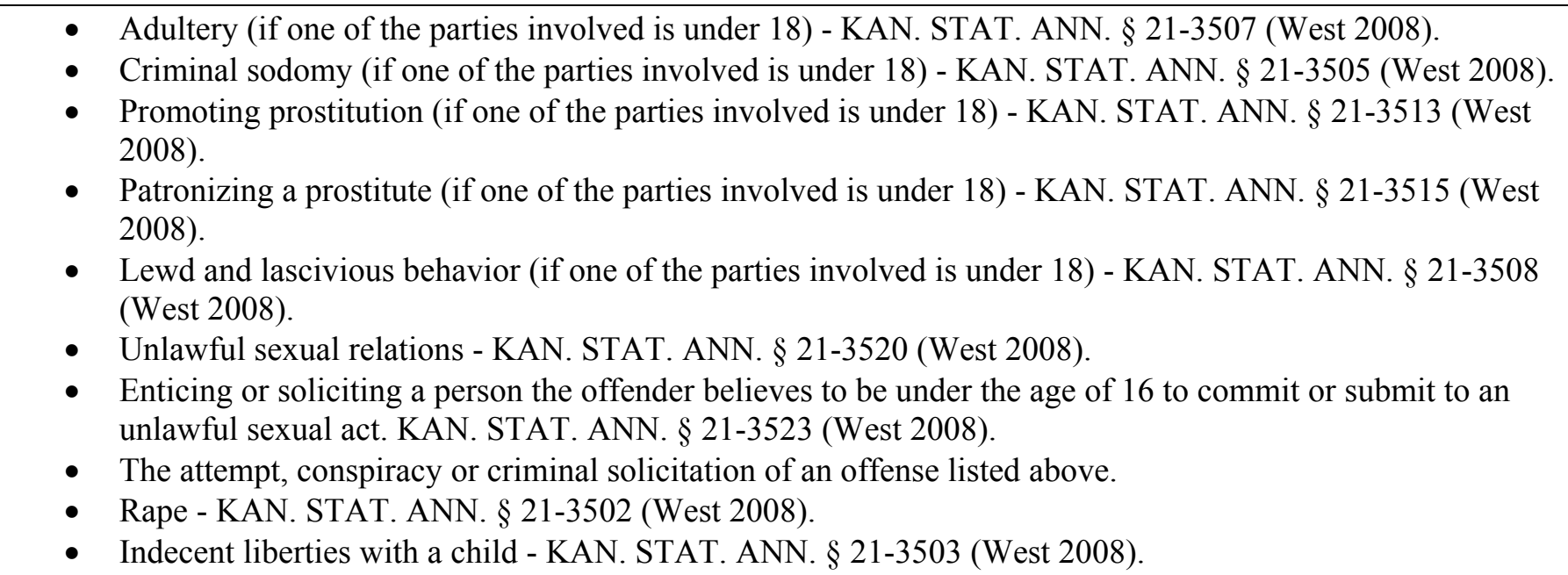 \\
\hline
\end{tabular}

** Denotes those states where sex offender registration is required for convictions under the staff sexual misconduct laws of the states. Staff and inmates could also be required to register as sex offenders if the offense were charged under other registrable offenses.

This publication is developed by the NIC/WCL Project on Addressing Prison Rape under NIC Cooperative Agreement 06S20GJJ1.

This is not to be posted or reproduced without permission from the authors.

American University, Washington College of Law

Current as of August 2009 


\section{Fifty State Survey of Adult Sex Offender Registration Requirements}

\section{NIC/WCL Project on Addressing Prison Rape}

\begin{tabular}{|c|c|}
\hline $\begin{array}{l}\text { Registrable Offenses Cont'd } \\
\text { (Kansas) }\end{array}$ & 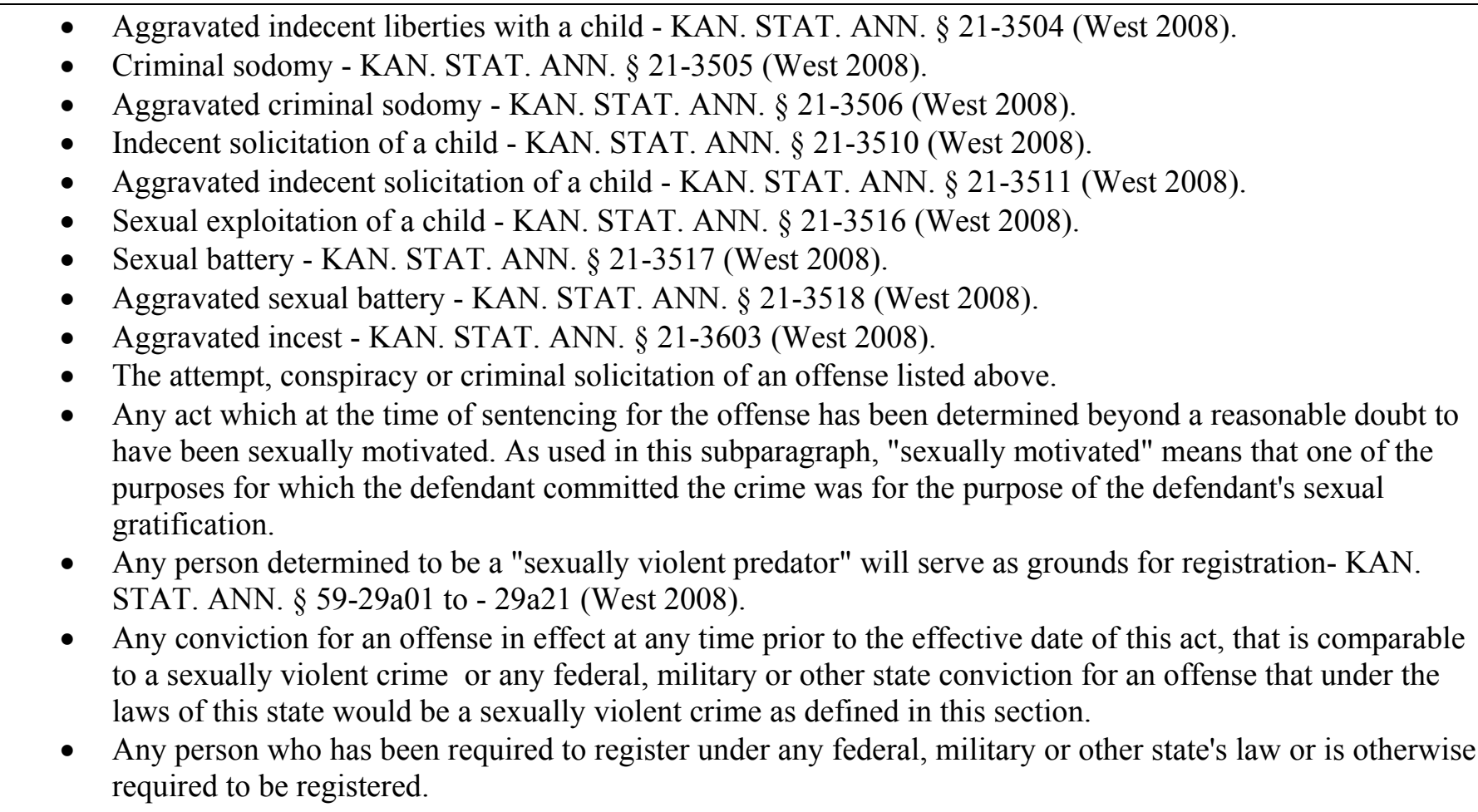 \\
\hline $\begin{array}{l}\text { Sex Offender Registration } \\
\text { Required for Staff Sexual } \\
\text { Misconduct? } \\
\text { (Kansas) }\end{array}$ & $\begin{array}{l}\text { YES, but only if the victim is less than } 18 \text { years of age. } \\
\text { K.S.A. } \S 21-3520 \text { (West } 2008 \text { ) } \\
\text { (a) Unlawful sexual relations is engaging in consensual sexual intercourse, lewd fondling or touching, or sodomy } \\
\text { with a person who is not married to the offender if: }\end{array}$ \\
\hline
\end{tabular}

** Denotes those states where sex offender registration is required for convictions under the staff sexual misconduct laws of the states. Staff and inmates could also be required to register as sex offenders if the offense were charged under other registrable offenses.

This publication is developed by the NIC/WCL Project on Addressing Prison Rape under NIC Cooperative Agreement 06S20GJJ1.

This is not to be posted or reproduced without permission from the authors.

American University, Washington College of Law

Current as of August 2009 


\section{Fifty State Survey of Adult Sex Offender Registration Requirements}

\section{NIC/WCL Project on Addressing Prison Rape}

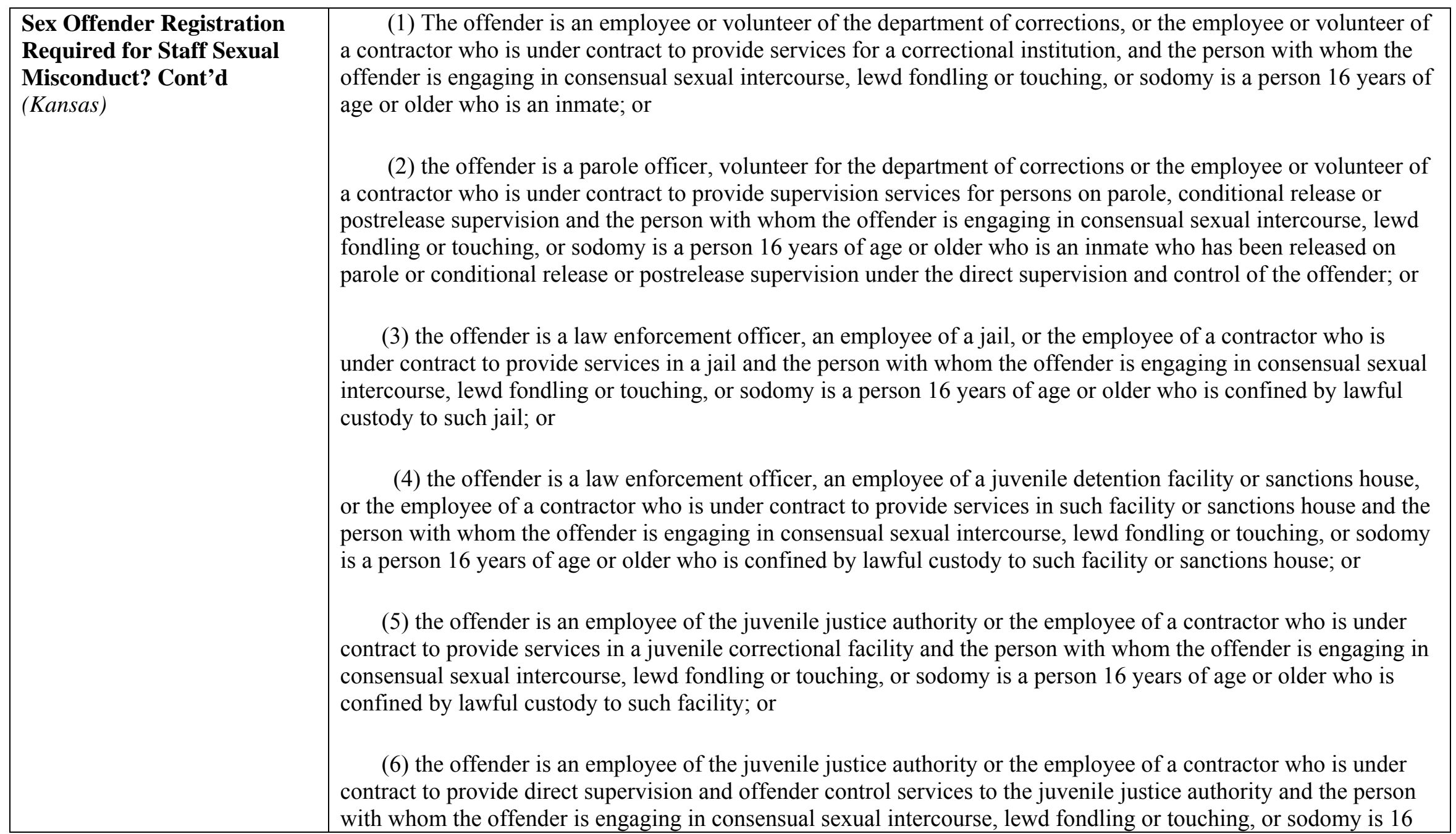

** Denotes those states where sex offender registration is required for convictions under the staff sexual misconduct laws of the states. Staff and 80 inmates could also be required to register as sex offenders if the offense were charged under other registrable offenses.

This publication is developed by the NIC/WCL Project on Addressing Prison Rape under NIC Cooperative Agreement 06S20GJJ1.

This is not to be posted or reproduced without permission from the authors.

American University, Washington College of Law

Current as of August 2009 


\section{Fifty State Survey of Adult Sex Offender Registration Requirements}

\section{NIC/WCL Project on Addressing Prison Rape}

\begin{tabular}{|c|c|}
\hline $\begin{array}{l}\text { Sex Offender Registration } \\
\text { Required for Staff Sexual } \\
\text { Misconduct? Cont'd } \\
\text { (Kansas) }\end{array}$ & $\begin{array}{l}\text { years of age or older and (A) released on conditional release from a juvenile correctional facility under the } \\
\text { supervision and control of the juvenile justice authority or juvenile community supervision agency or (B) placed in } \\
\text { the custody of the juvenile justice authority under the supervision and control of the juvenile justice authority or } \\
\text { juvenile community supervision agency and the offender has knowledge that the person with whom the offender is } \\
\text { engaging in consensual sexual intercourse, lewd fondling or touching, or sodomy is currently under supervision; } \\
\qquad(7) \text { the offender is an employee of the department of social and rehabilitation services or the employee of a } \\
\text { contractor who is under contract to provide services in a social and rehabilitation services institution and the person } \\
\text { with whom the offender is engaging in consensual sexual intercourse, not otherwise subject to subsection (a)(1)(C) } \\
\text { of K.S.A. } 21-3502 \text {, and amendments thereto, lewd fondling or touching, or sodomy, not otherwise subject to } \\
\text { subsection (a)(3)(C) of K.S.A. } 21-3506 \text {, and amendments thereto, is a person } 16 \text { years of age or older who is a } \\
\text { patient in such institution; }\end{array}$ \\
\hline $\begin{array}{l}\text { Information Maintained in } \\
\text { Sex Offender Registry } \\
\text { (Kansas) }\end{array}$ & $\begin{array}{l}\text { K.S.A. } § 22-4907 \text { (WEST 2008) } \\
\text { (a) Registration as required by this act shall consist of a form prepared by the Kansas bureau of investigation, which } \\
\text { shall include a statement that the requirements provided in this section have been explained to the person, and shall } \\
\text { be signed by the person. Such registration form shall include the following: } \\
\text { (1) Name; } \\
\text { (2) date and place of birth; } \\
\text { (3) offense or offenses committed, date of conviction or convictions obtained; } \\
\text { (4) city or county of conviction or convictions obtained; } \\
\text { (5) sex and age of victim; } \\
\text { (6) current address; } \\
\text { (7) social security number; } \\
\text { (8) identifying characteristics such as race, skin tone, sex, age, hair and eye color, scars, tattoos and blood type; } \\
\text { (9) occupation, name of employer and place of employment; } \\
\text { (10) drivers license and vehicle information, including the registration number of each license plate assigned to }\end{array}$ \\
\hline
\end{tabular}

** Denotes those states where sex offender registration is required for convictions under the staff sexual misconduct laws of the states. Staff and 81 inmates could also be required to register as sex offenders if the offense were charged under other registrable offenses.

This publication is developed by the NIC/WCL Project on Addressing Prison Rape under NIC Cooperative Agreement 06S20GJJ1.

This is not to be posted or reproduced without permission from the authors.

American University, Washington College of Law

Current as of August 2009 


\section{Fifty State Survey of Adult Sex Offender Registration Requirements}

\section{NIC/WCL Project on Addressing Prison Rape}

\begin{tabular}{|c|c|}
\hline $\begin{array}{l}\text { Information Maintained in } \\
\text { Sex Offender Registry } \\
\text { Cont'd } \\
\text { (Kansas) }\end{array}$ & $\begin{array}{l}\text { (11) documentation of any treatment received for a mental abnormality or personality disorder of the offender; } \\
\text { for purposes of documenting the treatment received, sheriffs, prison officials and courts may rely on } \\
\text { information that is readily available to them from existing records and the offender. } \\
\text { (12) anticipated future residence } \\
\text { (13) a photograph; } \\
\text { (14) fingerprints; } \\
\text { (15) school; and } \\
\text { (16) any and all e-mail addresses and online identities used by the offender on the internet. } \\
\text { (b)(1) The offender shall also provide to the registering law enforcement agency DNA exemplars, unless already on } \\
\text { file. }\end{array}$ \\
\hline $\begin{array}{l}\text { Community Notification } \\
\text { and Websites } \\
\text { (Kansas) }\end{array}$ & $\begin{array}{l}\text { K.S.A. } \$ 22-4909 \text { (West 2008) } \\
\text { (a) The statements or any other information required by this act shall be open to inspection by the: } \\
\text { - Public at the sheriff's office, } \\
\text { - At the headquarters of the Kansas bureau of investigation and } \\
\text { - On any internet website sponsored or created by a sheriff's department or the Kansas bureau of investigation } \\
\text { that contains such statements or information. } \\
\text { (b) Any information posted on an internet website sponsored or created by a sheriff's office or the Kansas bureau of } \\
\text { investigation shall identify, in a prominent manner, whether an offender is or is not a sex offender. } \\
\text { (c) The state department of education shall annually notify any school upon which is located a structure used by a } \\
\text { unified school district or an accredited nonpublic school for student instruction or attendance or extracurricular } \\
\text { activities of pupils enrolled in kindergarten or any grades one through } 12 \text { of the Kansas bureau of investigation } \\
\text { internet website and any internet website containing information on the Kansas offender registration sponsored or } \\
\text { created by the sheriff of the county in which the school is located for the purposes of locating offenders who reside } \\
\text { near such school. }\end{array}$ \\
\hline
\end{tabular}

** Denotes those states where sex offender registration is required for convictions under the staff sexual misconduct laws of the states. Staff and inmates could also be required to register as sex offenders if the offense were charged under other registrable offenses.

This publication is developed by the NIC/WCL Project on Addressing Prison Rape under NIC Cooperative Agreement 06S20GJJ1.

This is not to be posted or reproduced without permission from the authors.

American University, Washington College of Law

Current as of August 2009 


\section{Fifty State Survey of Adult Sex Offender Registration Requirements}

\section{NIC/WCL Project on Addressing Prison Rape}

\begin{tabular}{|c|c|}
\hline $\begin{array}{l}\text { Community Notification } \\
\text { and Websites Cont'd } \\
\text { (Kansas) }\end{array}$ & $\begin{array}{l}\text { (d) The secretary of health and environment shall annually notify any licensed child care facility of the Kansas } \\
\text { bureau of investigation internet website and any internet website containing information on the Kansas offender } \\
\text { registration sponsored or created by the sheriff of the county in which the facility is located for the purposes of } \\
\text { locating offenders who reside near such facility. }\end{array}$ \\
\hline $\begin{array}{l}\text { Limitations on Residency or } \\
\text { Employment } \\
\text { (Kansas) }\end{array}$ & None. \\
\hline $\begin{array}{l}\text { Duration of Registration } \\
\text { (Kansas) }\end{array}$ & $\begin{array}{l}\text { K.S.A. } § 22-4906 \text { (WEST 2008) } \\
\text { (a) } 10 \text { years for persons convicted of a registrable offense. } \\
\text { (b) Lifetime registration: } \\
\text { - Upon a second or subsequent conviction for a registrable offense; } \\
\text { - For persons convicted of an aggravated offense } \\
\text { - For sexually violent predators. }\end{array}$ \\
\hline \multicolumn{2}{|r|}{ KENTUCKY $^{2 * *}$} \\
\hline $\begin{array}{l}\text { Registrable Offenses } \\
\text { (Kentucky) }\end{array}$ & $\begin{array}{l}\text { - Kidnapping (of a person under the age of 18), except by a parent - KY. REV. STAT. ANN. } \S 509.040 \\
\text { (West 2008). } \\
\text { - Unlawful confinement (of a person under the age of 18), except by a parent - KY. REV. STAT. ANN. } \S \\
509.020 \text { (West 2008). } \\
\text { - Promoting a sexual performance of a minor - KY. REV. STAT. ANN. § } 531.320 \text { (West 2008). }\end{array}$ \\
\hline
\end{tabular}

** Denotes those states where sex offender registration is required for convictions under the staff sexual misconduct laws of the states. Staff and inmates could also be required to register as sex offenders if the offense were charged under other registrable offenses.

This publication is developed by the NIC/WCL Project on Addressing Prison Rape under NIC Cooperative Agreement 06S20GJJ1.

This is not to be posted or reproduced without permission from the authors.

American University, Washington College of Law

Current as of August 2009 


\section{Fifty State Survey of Adult Sex Offender Registration Requirements}

\section{NIC/WCL Project on Addressing Prison Rape}

\begin{tabular}{|c|c|}
\hline $\begin{array}{l}\text { Registrable Offenses Cont'd } \\
\text { (Kentucky) }\end{array}$ & 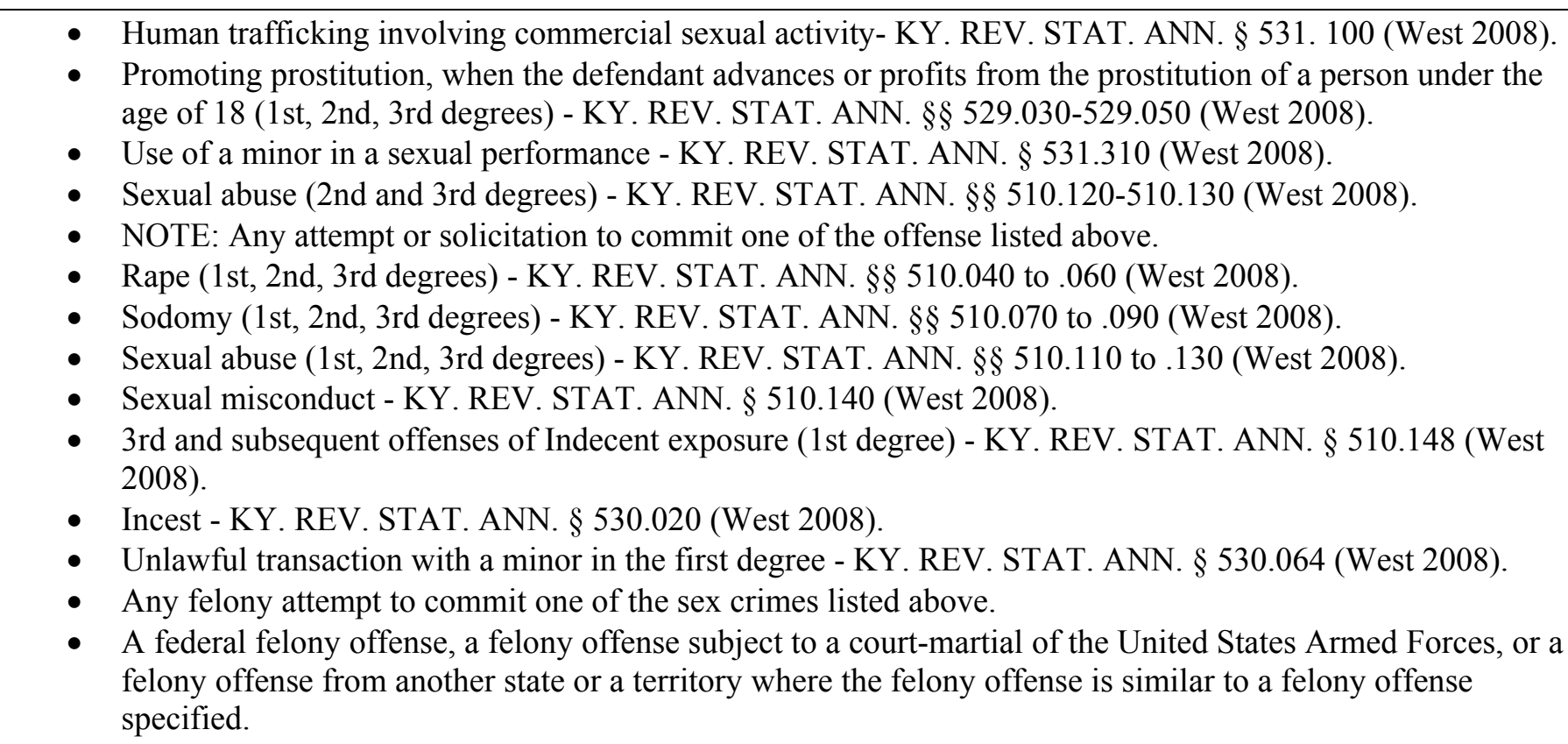 \\
\hline $\begin{array}{l}\text { Sex Offender Registration } \\
\text { Required for Staff Sexual } \\
\text { Misconduct? } \\
\text { (Kentucky) }\end{array}$ & $\begin{array}{l}\text { YES. } \\
\text { K.R.S. } § 510.120 \text { (West 2008) } \\
\text { (1) A person is guilty of sexual abuse in the second degree when: } \\
\text { (c) Being an employee, contractor, vendor, or volunteer of the Department of Corrections, or a detention facility as } \\
\text { defined in KRS 520.010, or of an entity under contract with either the department or a detention facility for the } \\
\text { custody, supervision, evaluation, or treatment of offenders, he or she subjects an offender who is incarcerated, } \\
\text { supervised, evaluated, or treated by the Department of Corrections, the detention facility, or the contracting entity, }\end{array}$ \\
\hline
\end{tabular}

** Denotes those states where sex offender registration is required for convictions under the staff sexual misconduct laws of the states. Staff and inmates could also be required to register as sex offenders if the offense were charged under other registrable offenses.

This publication is developed by the NIC/WCL Project on Addressing Prison Rape under NIC Cooperative Agreement 06S20GJJ1.

This is not to be posted or reproduced without permission from the authors.

American University, Washington College of Law

Current as of August 2009 


\section{Fifty State Survey of Adult Sex Offender Registration Requirements}

\section{NIC/WCL Project on Addressing Prison Rape}

\begin{tabular}{|c|c|}
\hline $\begin{array}{l}\text { Sex Offender Registration } \\
\text { Required for Staff Sexual } \\
\text { Misconduct? Cont'd } \\
\text { (Kentucky) }\end{array}$ & $\begin{array}{l}\text { to sexual contact. In any prosecution under this paragraph, the defendant may prove in exculpation that, at the time } \\
\text { he or she engaged in the conduct constituting the offense, he or she and the offender were married to each other. }\end{array}$ \\
\hline $\begin{array}{l}\text { Information Maintained in } \\
\text { Sex Offender Registry } \\
\text { (Kentucky) }\end{array}$ & $\begin{array}{l}\text { KY. REV. STAT. ANN. } \$ 17.500 \text { (West 2008) } \\
\text { (6): } \\
\text { - name } \\
\text { - social security number } \\
\text { - age } \\
\text { - race } \\
\text { - sex } \\
\text { - date of birth } \\
\text { - height } \\
\text { - weight } \\
\text { - hair and eye color } \\
\text { - fingerprints } \\
\text { - photograph } \\
\text { - aliases used } \\
\text { - residence } \\
\text { - brief description of the crime(s) committed } \\
\text { - other information deemed useful in the identification of registrants } \\
\text { 2009 Kentucky Laws Ch. } 105 \text { (HB } 321 \text { ) (West 2008) } \\
\text { 2) The following persons shall have a DNA sample collected by authorized personnel: } \\
\text { (a) Any person convicted on or after the effective date of this Act July 1, 2008, of a felony offense under under the } \\
\text { Kentucky Revised Statutes; or }\end{array}$ \\
\hline
\end{tabular}

** Denotes those states where sex offender registration is required for convictions under the staff sexual misconduct laws of the states. Staff and inmates could also be required to register as sex offenders if the offense were charged under other registrable offenses.

This publication is developed by the NIC/WCL Project on Addressing Prison Rape under NIC Cooperative Agreement 06S20GJJ1.

This is not to be posted or reproduced without permission from the authors.

American University, Washington College of Law

Current as of August 2009 


\section{Fifty State Survey of Adult Sex Offender Registration Requirements}

\section{NIC/WCL Project on Addressing Prison Rape}

\begin{tabular}{|c|c|}
\hline $\begin{array}{l}\text { Information Maintained in } \\
\text { Sex Offender Registry } \\
\text { Cont'd } \\
\text { (Kentucky) }\end{array}$ & $\begin{array}{l}\text { (b) Any juvenile who was at least fourteen (14) years of age at the time of the commission of the offense and who } \\
\text { stands adjudicated delinquent of being a public offender by a court of competent jurisdiction, of: } 1 \text {. Any felony } \\
\text { offense in KRS Chapter 510; 2. Incest as defined in KRS 530.020; 3. Criminal attempt or criminal conspiracy to } \\
\text { commit an offense identified in subparagraph 1. or } 2 \text {. of this paragraph; or 4. Being a juvenile sexual offender } \\
\text { under KRS 635.510, being thirteen (13) years of age or older at the time of the commission of the offense, } \\
\text { adjudicated as a public offender for an offense identified in KRS } 439.3401(1) \text { or } 530.020 \text { on or after July } 1,2008 \text {, or } \\
\text { who is in the custody of the Department of Corrections, the Department of Juvenile Justice, or a local or county jail } \\
\text { on or after July } 1,2008 \text {, based upon a conviction or adjudication of an offense identified in this subsection, shall } \\
\text { have a DNA sample collected by authorized personnel. }\end{array}$ \\
\hline $\begin{array}{l}\text { Community Notification } \\
\text { and Websites } \\
\text { (Kentucky) }\end{array}$ & $\begin{array}{l}\text { K.R.S. } \$ 17.580 \\
\text { (1) The Kentucky State Police shall establish a Web site available to the public. } \\
\text { (6) In addition to the Web site, a local law enforcement agency may provide personal notification regarding the } \\
\text { registrants located in its jurisdiction. }\end{array}$ \\
\hline $\begin{array}{l}\text { Limitations on Residency or } \\
\text { Employment } \\
\text { (Kentucky) }\end{array}$ & $\begin{array}{l}2006 \text { Kentucky House Bill No. 3, Kentucky } 2006 \text { Regular Session (West 2008) } \\
\text { KRS } 17.500 \text { to } 17.580 \text {, and amended to read as follows: } \\
\text { (1) No registrant, as defined in KRS 17.500,-who is placed on probation, parole, or any form of supervised release, } \\
\text { shall reside within one thousand (1,000) feet of a high school, middle school, elementary school, preschool, } \\
\text { publicly owned playground, or licensed day care facility. The measurement shall be taken in a straight line from } \\
\text { the nearest property line of the school to the nearest property line thall of the registrant's place of residence. } \\
\text { (2) For purposes of this section:(a) The registrant shall have the duty to ascertain whether any property listed in } \\
\text { subsection (1) of this section is within one thousand (1,000) feet of the registrant's residence; and (b) If a new } \\
\text { facility opens, the registrant shall be presumed to know and, within ninety (90) days, shall comply with this } \\
\text { section. }\end{array}$ \\
\hline
\end{tabular}

** Denotes those states where sex offender registration is required for convictions under the staff sexual misconduct laws of the states. Staff and inmates could also be required to register as sex offenders if the offense were charged under other registrable offenses.

This publication is developed by the NIC/WCL Project on Addressing Prison Rape under NIC Cooperative Agreement 06S20GJJ1.

This is not to be posted or reproduced without permission from the authors.

American University, Washington College of Law

Current as of August 2009 


\section{Fifty State Survey of Adult Sex Offender Registration Requirements}

\section{NIC/WCL Project on Addressing Prison Rape}

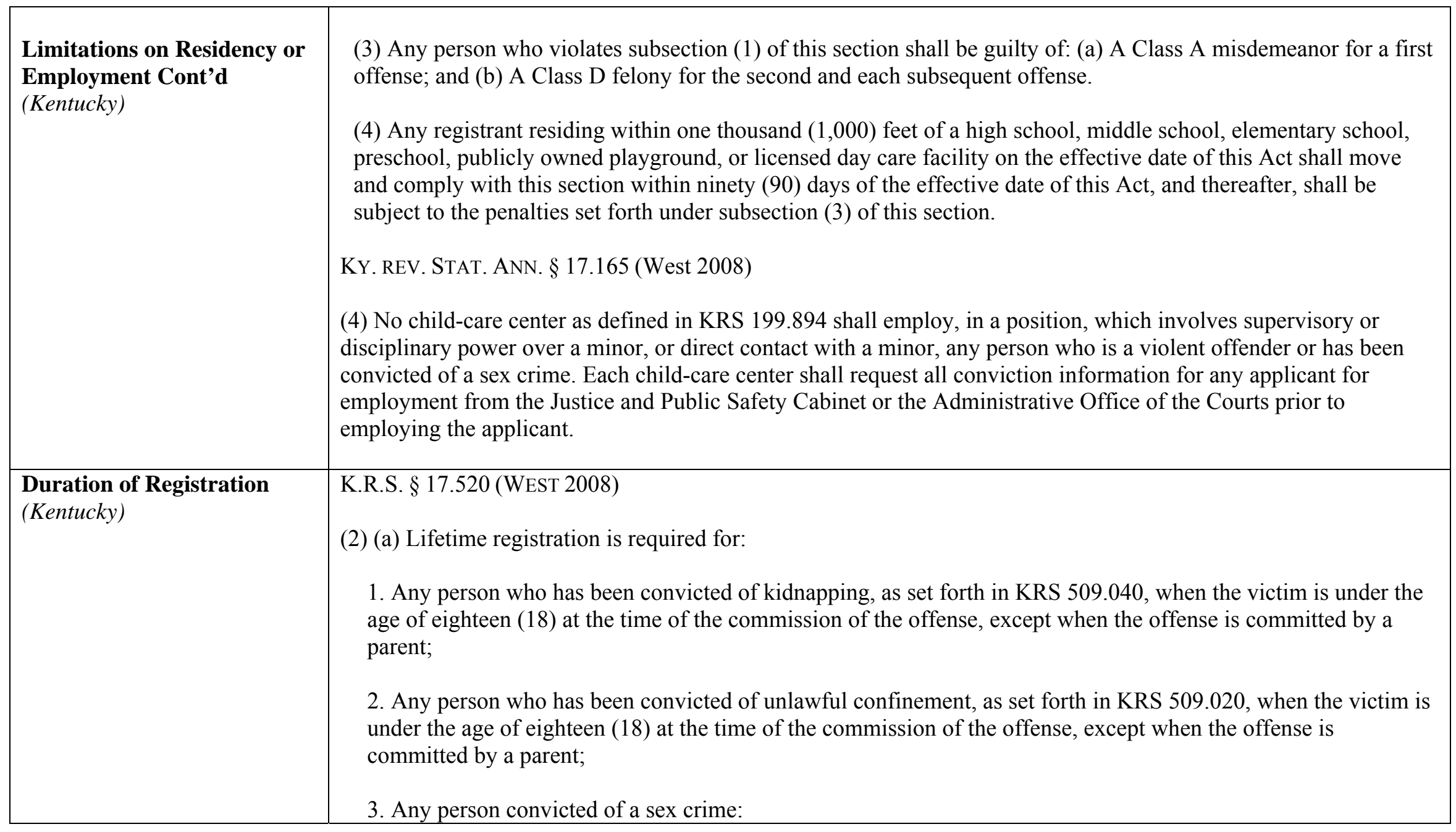

** Denotes those states where sex offender registration is required for convictions under the staff sexual misconduct laws of the states. Staff and inmates could also be required to register as sex offenders if the offense were charged under other registrable offenses.

This publication is developed by the NIC/WCL Project on Addressing Prison Rape under NIC Cooperative Agreement 06S20GJJ1.

This is not to be posted or reproduced without permission from the authors.

American University, Washington College of Law

Current as of August 2009 


\section{Fifty State Survey of Adult Sex Offender Registration Requirements}

\section{NIC/WCL Project on Addressing Prison Rape}

\begin{tabular}{|c|c|}
\hline $\begin{array}{l}\text { Duration of Registration } \\
\text { Cont'd } \\
\text { (Kentucky) }\end{array}$ & $\begin{array}{l}\text { a. Who has one (1) or more prior convictions of a felony criminal offense against a victim who is a minor; } \\
\text { or } \\
\text { b. Who has one (1) or more prior sex crime convictions; } \\
\text { 4. Any person who has been convicted of two (2) or more felony criminal offenses against a victim who is a } \\
\text { minor; } \\
\text { 5. Any person who has been convicted of: } \\
\text { a. Rape in the first degree under KRS } 510.040 \text {; or } \\
\text { b. Sodomy in the first degree under KRS 510.070; and } \\
\text { 6. Any sexually violent predator. } \\
\text { (3) } 20 \text { years for all registrants not subject to lifetime registration. }\end{array}$ \\
\hline & LOUISIANA \\
\hline
\end{tabular}

** Denotes those states where sex offender registration is required for convictions under the staff sexual misconduct laws of the states. Staff and inmates could also be required to register as sex offenders if the offense were charged under other registrable offenses.

This publication is developed by the NIC/WCL Project on Addressing Prison Rape under NIC Cooperative Agreement 06S20GJJ1.

This is not to be posted or reproduced without permission from the authors.

American University, Washington College of Law

Current as of August 2009 


\section{Fifty State Survey of Adult Sex Offender Registration Requirements}

\section{NIC/WCL Project on Addressing Prison Rape}

\begin{tabular}{|c|c|}
\hline $\begin{array}{l}\text { Registrable Offenses Cont'd } \\
\text { (Louisiana) }\end{array}$ & 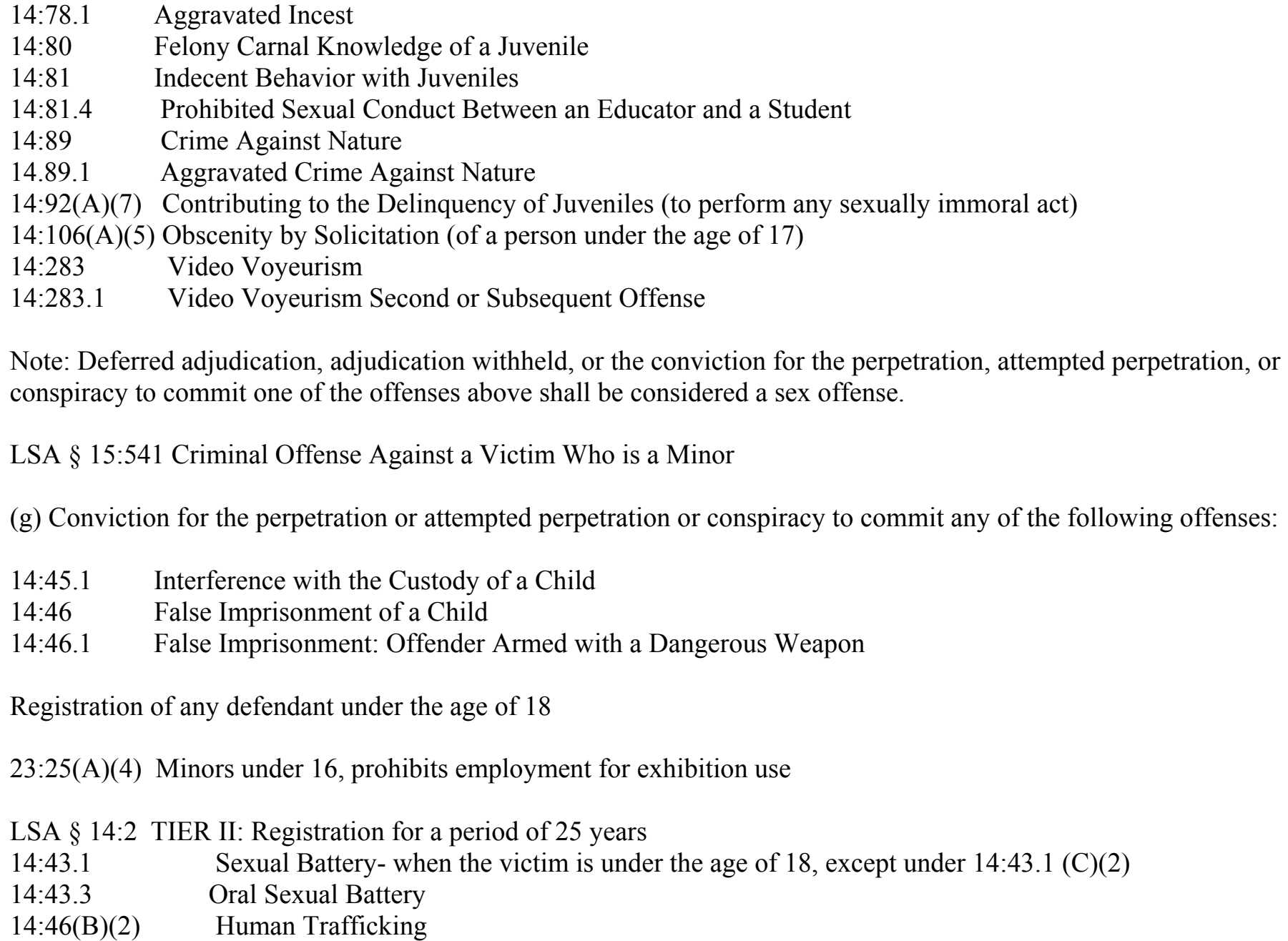 \\
\hline
\end{tabular}

** Denotes those states where sex offender registration is required for convictions under the staff sexual misconduct laws of the states. Staff and inmates could also be required to register as sex offenders if the offense were charged under other registrable offenses.

This publication is developed by the NIC/WCL Project on Addressing Prison Rape under NIC Cooperative Agreement 06S20GJJ1.

This is not to be posted or reproduced without permission from the authors.

American University, Washington College of Law

Current as of August 2009 


\section{Fifty State Survey of Adult Sex Offender Registration Requirements}

\section{NIC/WCL Project on Addressing Prison Rape}

\begin{tabular}{|c|c|}
\hline $\begin{array}{l}\text { Registrable Offenses Cont'd } \\
\text { (Louisiana) }\end{array}$ & 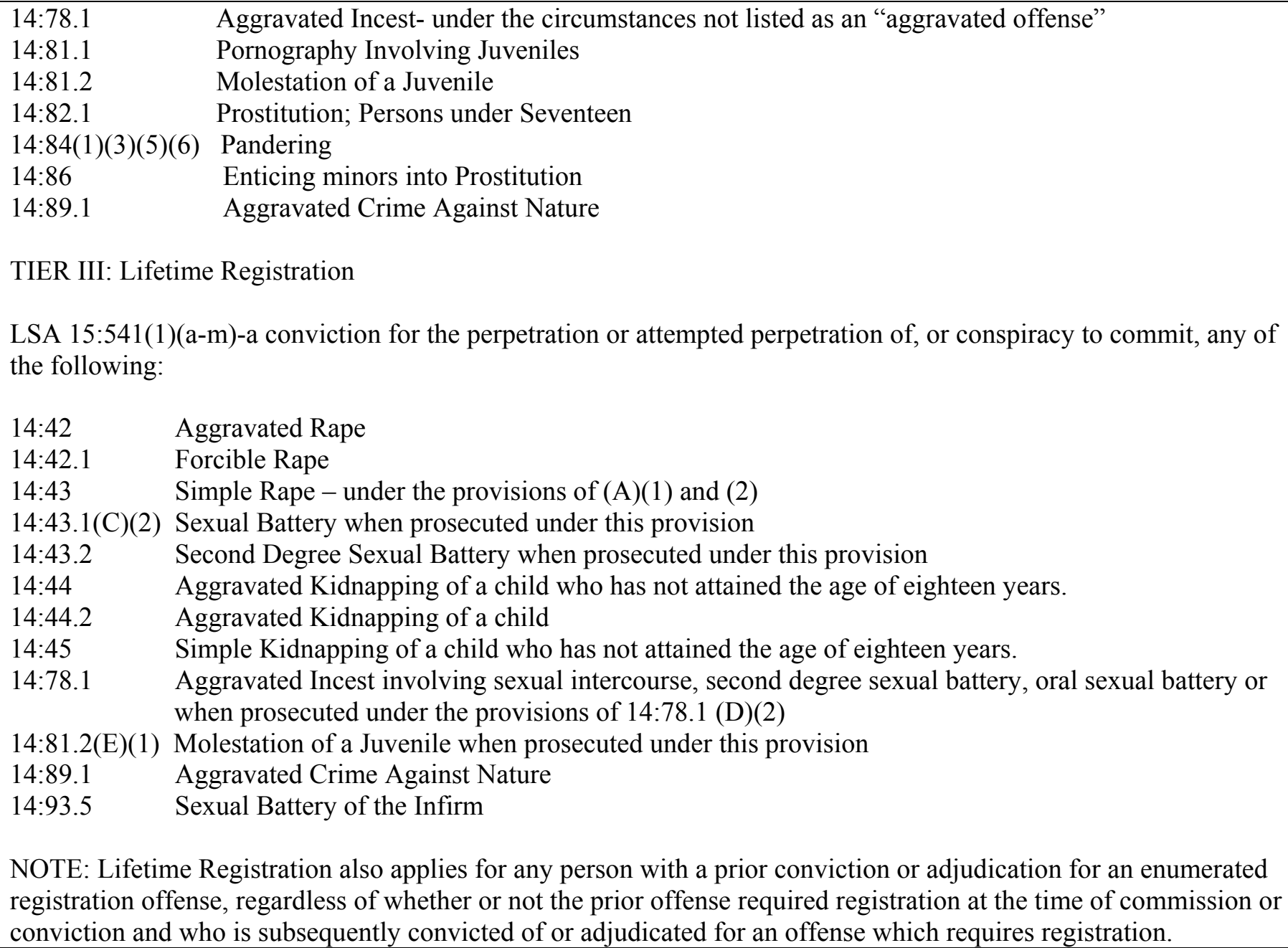 \\
\hline
\end{tabular}

** Denotes those states where sex offender registration is required for convictions under the staff sexual misconduct laws of the states. Staff and inmates could also be required to register as sex offenders if the offense were charged under other registrable offenses.

This publication is developed by the NIC/WCL Project on Addressing Prison Rape under NIC Cooperative Agreement 06S20GJJ1.

This is not to be posted or reproduced without permission from the authors.

American University, Washington College of Law

Current as of August 2009 


\section{Fifty State Survey of Adult Sex Offender Registration Requirements}

\section{NIC/WCL Project on Addressing Prison Rape}

\begin{tabular}{|c|c|}
\hline $\begin{array}{l}\text { Registrable Offenses Cont'd } \\
\text { (Louisiana) }\end{array}$ & $\begin{array}{l}\text { NOTE: A conviction for any offense provided in the above lists includes a conviction for an equivalent offense } \\
\text { under the laws of another state, military, territorial, tribal, or federal law. } \\
\text { NOTE: A conviction for the perpetration, attempted perpetration, or conspiracy to commit all of the offenses } \\
\text { outlined above shall be considered as a child predator for all circumstances. }\end{array}$ \\
\hline $\begin{array}{l}\text { Sex Offender Registration } \\
\text { Required for Staff Sexual } \\
\text { Misconduct? } \\
\text { (Louisiana) }\end{array}$ & NO \\
\hline $\begin{array}{l}\text { Information Maintained in } \\
\text { Sex Offender Registry } \\
\text { (Louisiana) }\end{array}$ & $\begin{array}{l}\text { LSA-R.S. } \S 15: 542 \text { (WEST 2008) } \\
\text { C. (1) The offender shall register and provide all of the following information to the appropriate law enforcement } \\
\text { agencies listed in Subsection B of this Section in accordance with the time period provided for in Paragraph (2) of } \\
\text { this Subsection: } \\
\text { (a) Name and any aliases used by the offender. } \\
\text { (b) Physical address or addresses of residence. } \\
\text { (c) Name and physical address of place of employment. If the offender does not have a fixed place of } \\
\text { employment, the offender shall provide information with as much specificity as possible regarding the } \\
\text { places where he works, including but not limited to travel routes used by the offender. } \\
\text { (d) Name and physical address of the school in which he is a student. } \\
\text { (e) Two forms of proof of residence for each residential address provided, including but not limited to a } \\
\text { driver's license, bill for utility service, and bill for telephone service. If those forms of proof of residence } \\
\text { are not available, the offender may provide an affidavit of an adult resident living at the same address. The } \\
\text { affidavit shall certify that the affiant understands his obligation to provide written notice pursuant to R.S. } \\
15: 542.1 .4 \text { to the appropriate law enforcement agency with whom the offender last registered when the } \\
\text { offender no longer resides at the residence provided in the affidavit. } \\
\text { (f) The crime for which he was convicted and the date and place of such conviction, and if known by the }\end{array}$ \\
\hline
\end{tabular}

** Denotes those states where sex offender registration is required for convictions under the staff sexual misconduct laws of the states. Staff and inmates could also be required to register as sex offenders if the offense were charged under other registrable offenses.

This publication is developed by the NIC/WCL Project on Addressing Prison Rape under NIC Cooperative Agreement 06S20GJJ1.

This is not to be posted or reproduced without permission from the authors.

American University, Washington College of Law

Current as of August 2009 


\section{Fifty State Survey of Adult Sex Offender Registration Requirements}

\section{NIC/WCL Project on Addressing Prison Rape}

\begin{tabular}{|c|c|}
\hline $\begin{array}{l}\text { Information Maintained in } \\
\text { Sex Offender Registry } \\
\text { Cont'd } \\
\text { (Louisiana) }\end{array}$ & $\begin{array}{l}\text { offender, the court in which the conviction was obtained, the docket number of the case, the specific statute } \\
\text { under which he was convicted, and the sentence imposed. } \\
\text { (g) A current photograph. } \\
\text { (h) Fingerprints, palm prints, and a DNA sample. } \\
\text { (i) Telephone numbers, including fixed location phone and mobile phone numbers assigned to the offender or } \\
\text { associated with any residence address of the offender. } \\
\text { (j) A description of every vehicle registered to or operated by the offender, including license plate number and } \\
\text { a copy of the offender's driver's license or identification card. } \\
\text { (k) Social security number and date of birth. } \\
\text { (l) A description of the physical characteristics of the offender, including but not limited to sex, race, hair } \\
\text { color, eye color, height, age, weight, scars, tattoos, or other identifying marks on the body of the offender. } \\
\text { (m) Every e-mail address, online screen name, or other online identifiers used by the offender to communicate } \\
\text { on the Internet. Required notice must be given before any online identifier is used to communicate on the } \\
\text { Internet. } \\
\text { (n) Temporary lodging information regarding any place where the offender plans to stay for seven or more } \\
\text { days. } \\
\text { (o) Travel and immigration documents, including but not limited to passports and documents establishing } \\
\text { immigration status. }\end{array}$ \\
\hline $\begin{array}{l}\text { Community Notification } \\
\text { and Websites } \\
\text { (Louisiana) }\end{array}$ & $\begin{array}{l}\text { LSA-R.S. } § 15: 546 \text { (West 2008) } \\
\text { (A): Criminal justice agencies shall release relevant and necessary information regarding sex offenders, child } \\
\text { predators, and sexually violent predators to the public when the release of the information is necessary for public } \\
\text { protection. }\end{array}$ \\
\hline $\begin{array}{l}\text { Limitations on Residency or } \\
\text { Employment } \\
\text { (Louisiana) }\end{array}$ & $\begin{array}{l}\text { LSA-R.S. } § 14: 91.2 \text { (West 2008) } \\
\text { A. The following acts when committed by a person convicted of a sex offense as defined in R.S. 15:541 when the } \\
\text { victim is under the age of thirteen years shall constitute the crime of unlawful residence or presence of a sex } \\
\text { offender: }\end{array}$ \\
\hline
\end{tabular}

** Denotes those states where sex offender registration is required for convictions under the staff sexual misconduct laws of the states. Staff and inmates could also be required to register as sex offenders if the offense were charged under other registrable offenses.

This publication is developed by the NIC/WCL Project on Addressing Prison Rape under NIC Cooperative Agreement 06S20GJJ1.

This is not to be posted or reproduced without permission from the authors.

American University, Washington College of Law

Current as of August 2009 


\section{Fifty State Survey of Adult Sex Offender Registration Requirements}

\section{NIC/WCL Project on Addressing Prison Rape}

\begin{tabular}{|c|c|}
\hline $\begin{array}{l}\text { Limitations on Residency or } \\
\text { Employment Cont'd } \\
\text { (Louisiana) }\end{array}$ & 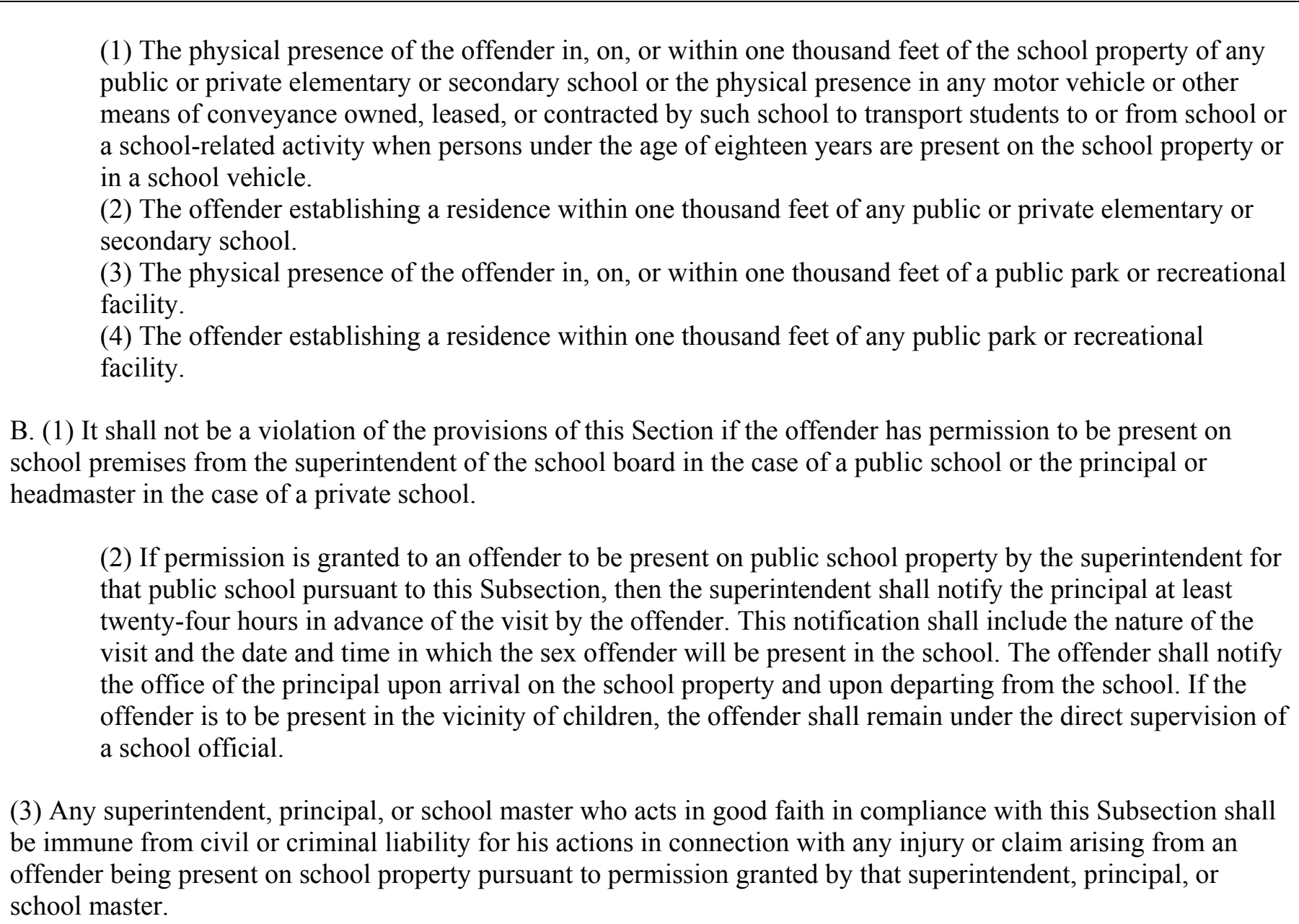 \\
\hline
\end{tabular}

** Denotes those states where sex offender registration is required for convictions under the staff sexual misconduct laws of the states. Staff and inmates could also be required to register as sex offenders if the offense were charged under other registrable offenses.

This publication is developed by the NIC/WCL Project on Addressing Prison Rape under NIC Cooperative Agreement 06S20GJJ1.

This is not to be posted or reproduced without permission from the authors.

American University, Washington College of Law

Current as of August 2009 


\section{Fifty State Survey of Adult Sex Offender Registration Requirements}

\section{NIC/WCL Project on Addressing Prison Rape}

Limitations on Residency or Employment Cont'd (Louisiana)
C. For purposes of this Section: (1) "School property" means any property used for school purposes, including but not limited to school buildings, playgrounds, and parking lots.

(2) "Public park or recreational facility" means any building or area owned by the state or by a political subdivision which is open to the public and used or operated as a park or recreational facility and shall include all parks and recreational areas administered by the office of state parks in the Department of Culture, Recreation and Tourism.

D. Whoever violates the provisions of this Section shall be fined not more than one thousand dollars, imprisoned with or without hard labor for not more one year, or both.

\section{LSA-R.S. § 14:91.1 (West 2008)}

A sexually violent predator may not be physically present on the property of any public or private school or in any vehicle used to transport students to and from school when persons under the age of 18 are present unless the offender has permission to be present from the school superintendent or headmaster.

Sexually violent predators may not physically reside within 1000 feet of any public or private school, day care facility, playground, youth center, public swimming pool or free-standing video arcade facility.

EFFECTIVE SEPTEMBER $1^{\text {st }} 2009$

LSA § 14:91.1 Unlawful Presence of a Sexually Violent Predator

A. Unlawful Presence of a Sexually Violent Predator is:

(2) The physical residing of a sexually violent predator within one thousand feet of any public or private elementary or secondary school [deleted text] center, group home, residential home, or child care facility, family child day care home, playground, public or private youth center, public swimming pool, or free standing video arcade facility.

** Denotes those states where sex offender registration is required for convictions under the staff sexual misconduct laws of the states. Staff and inmates could also be required to register as sex offenders if the offense were charged under other registrable offenses.

This publication is developed by the NIC/WCL Project on Addressing Prison Rape under NIC Cooperative Agreement 06S20GJJ1.

This is not to be posted or reproduced without permission from the authors.

American University, Washington College of Law

Current as of August 2009 


\section{Fifty State Survey of Adult Sex Offender Registration Requirements}

\section{NIC/WCL Project on Addressing Prison Rape}

\begin{tabular}{|c|c|}
\hline $\begin{array}{l}\text { Duration of Registration } \\
\text { (Louisiana) }\end{array}$ & $\begin{array}{l}\text { LSA-R.S. } \$ 15: 544 \text { (West 2008) } \\
\text { A. Except as provided for in Subsection B of this Section, a person required to register and provide notification } \\
\text { pursuant to the provisions of this Chapter shall comply with the requirement for a period of fifteen years from the } \\
\text { date of the initial registration, or the duration of the lifetime of the offender as provided in Subsection E of this } \\
\text { Section. The requirement to register shall apply to an offender who is pardoned. } \\
\text { B. (1) A person required to register pursuant to this Chapter who was convicted of a sexual offense against a victim } \\
\text { who is a minor as defined in R.S. 15:541 shall register and maintain his registration and provide community } \\
\text { notification pursuant to the provisions of this Chapter for a period of twenty-five years from the date of initial } \\
\text { registration, or the duration of the lifetime of the offender as provided in Subsection E of this Section, unless the } \\
\text { underlying conviction is reversed, set aside, or vacated. The requirement to register shall apply to an offender who } \\
\text { is pardoned. } \\
\text { E. (1) Notwithstanding the provisions of Subsection A or Paragraph (B)(1) of this Section, the court, upon motion } \\
\text { of the district attorney, and after a contradictory hearing, shall have the authority to order a person required to } \\
\text { register and provide notification pursuant to the provisions of this Chapter to register and notify for the duration of } \\
\text { the lifetime of the offender upon a showing by a preponderance of the evidence that the offender poses a substantial } \\
\text { risk of committing another offense requiring registration pursuant to this Chapter. }\end{array}$ \\
\hline & MAINE** \\
\hline $\begin{array}{l}\text { Registrable Offenses } \\
\text { (Maine) }\end{array}$ & $\begin{array}{l}\text { A conviction for one of the following offenses or for an attempt or solicitation of one of the following offenses if } \\
\text { the victim was less than } 18 \text { years of age at the time of the criminal conduct: } \\
\text { - Unlawful sexual contact - ME. REV. STAT. ANN. tit. 17, } \S 255-A(1)(\mathrm{A}),(\mathrm{B}),(\mathrm{C}),(\mathrm{G}),(\mathrm{I}),(\mathrm{J}),(\mathrm{K}),(\mathrm{L}) \text {, } \\
\text { (M), (N), (Q), (R), (S) or (T) (West 2008). } \\
\text { - Visual sexual aggression against child - ME. REV. STAT. ANN. tit. 17-A, } \S 256 \text { (West 2008). }\end{array}$ \\
\hline
\end{tabular}

** Denotes those states where sex offender registration is required for convictions under the staff sexual misconduct laws of the states. Staff and inmates could also be required to register as sex offenders if the offense were charged under other registrable offenses.

This publication is developed by the NIC/WCL Project on Addressing Prison Rape under NIC Cooperative Agreement 06S20GJJ1.

This is not to be posted or reproduced without permission from the authors.

American University, Washington College of Law

Current as of August 2009 


\section{Fifty State Survey of Adult Sex Offender Registration Requirements}

\section{NIC/WCL Project on Addressing Prison Rape}

\begin{tabular}{|c|c|}
\hline $\begin{array}{l}\text { Registrable Offenses } \\
\text { (Maine) }\end{array}$ & 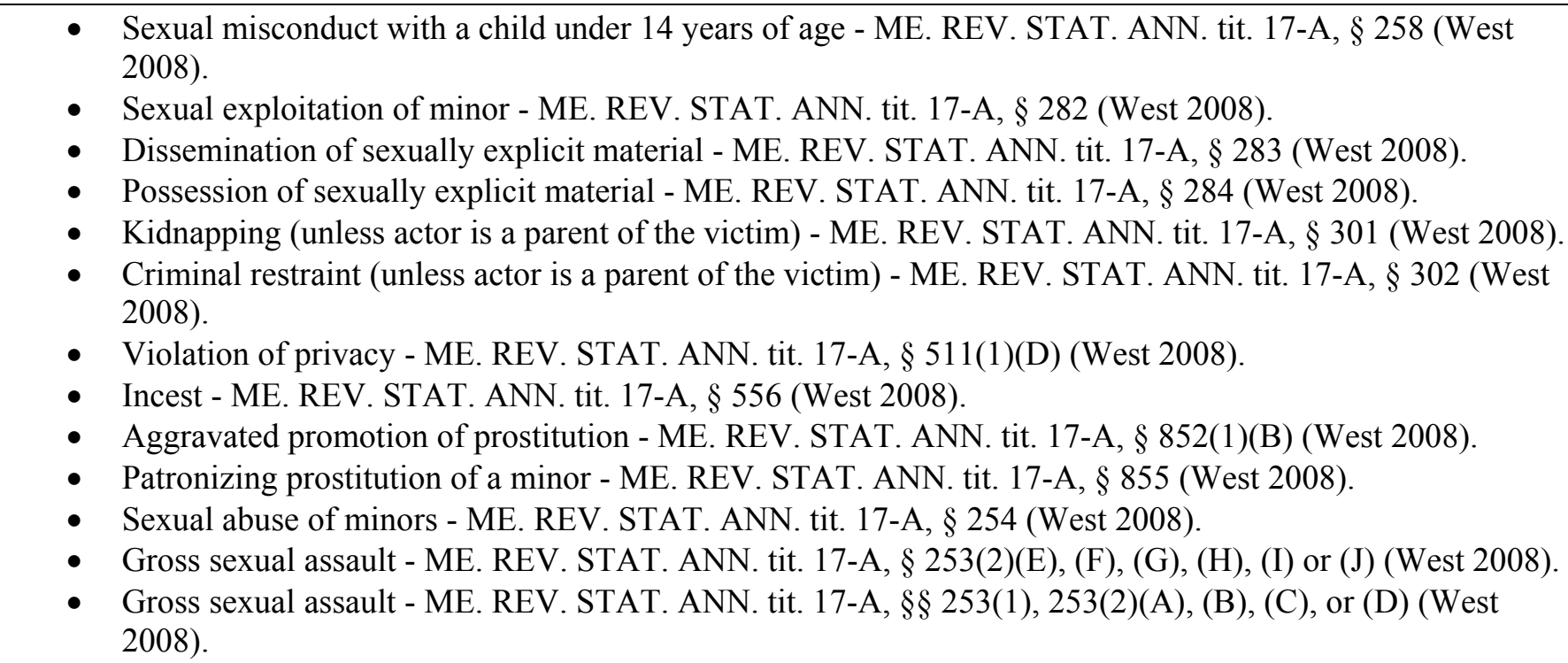 \\
\hline $\begin{array}{l}\text { Sex Offender Registration } \\
\text { Required for Staff Sexual } \\
\text { Misconduct? } \\
\text { (Maine) }\end{array}$ & $\begin{array}{l}\text { YES } \\
\text { 17-A M.R.S.A. } \S 253 \text { (West 2008) } \\
\text { Gross Sexual Assault. } \\
\text { 2. A person is guilty of gross sexual assault if that person engages in a sexual act with another person and: } \\
\text { A. The actor has substantially impaired the other person's power to appraise or control the other person's sexual } \\
\text { acts by furnishing, as defined in section } 1101 \text {, subsection } 18 \text {, paragraph A, administering or employing drugs, } \\
\text { intoxicants or other similar means. Violation of this paragraph is a Class B crime; } \\
\text { B. The actor compels or induces the other person to engage in the sexual act by any threat. Violation of this }\end{array}$ \\
\hline
\end{tabular}

** Denotes those states where sex offender registration is required for convictions under the staff sexual misconduct laws of the states. Staff and inmates could also be required to register as sex offenders if the offense were charged under other registrable offenses.

This publication is developed by the NIC/WCL Project on Addressing Prison Rape under NIC Cooperative Agreement 06S20GJJ1.

This is not to be posted or reproduced without permission from the authors.

American University, Washington College of Law

Current as of August 2009 


\section{Fifty State Survey of Adult Sex Offender Registration Requirements}

\section{NIC/WCL Project on Addressing Prison Rape}

\begin{tabular}{|c|c|}
\hline $\begin{array}{l}\text { Sex Offender Registration } \\
\text { Required for Staff Sexual } \\
\text { Misconduct? Cont'd } \\
\text { (Maine) }\end{array}$ & $\begin{array}{l}\text { paragraph is a Class B crime; } \\
\text { C. The other person suffers from mental disability that is reasonably apparent or known to the actor, and which } \\
\text { in fact renders the other person substantially incapable of appraising the nature of the contact involved or of } \\
\text { understanding that the person has the right to deny or withdraw consent. Violation of this paragraph is a Class B } \\
\text { crime; } \\
\text { D. The other person is unconscious or otherwise physically incapable of resisting and has not consented to the } \\
\text { sexual act. Violation of this paragraph is a Class B crime; } \\
\text { E. The other person, not the actor's spouse, is under official supervision as a probationer, a parolee, a sex } \\
\text { offender on supervised release, a prisoner on supervised community confinement status or a juvenile on community } \\
\text { reintegration status or is detained in a hospital, prison or other institution, and the actor has supervisory or } \\
\text { disciplinary authority over the other person. Violation of this paragraph is a Class B crime; } \\
\text { F. The other person, not the actor's spouse, has not in fact attained the age of } 18 \text { years and is a student enrolled in } \\
\text { a private or public elementary, secondary or special education school, facility or institution and the actor is a } \\
\text { teacher, employee or other official having instructional, supervisory or disciplinary authority over the student. } \\
\text { Violation of this paragraph is a Class C crime; }\end{array}$ \\
\hline $\begin{array}{l}\text { Information Maintained in } \\
\text { Sex Offender Registry } \\
\text { (Maine) }\end{array}$ & $\begin{array}{l}\text { 34-A M.R.S.A. } \$ 11221 \text { (Wet 2008) } \\
\begin{array}{l}\text { 1. Maintenance of registry. The bureau shall establish and maintain a registry of persons required to register } \\
\text { pursuant to this subchapter. The registry must include the following information on each registrant: }\end{array} \\
\text { A. The registrant's name, aliases, date of birth, sex, race, height, weight, eye color, mailing } \\
\text { address and physical location of expected domicile and residence; } \\
\text { B. Place of employment and college or school being attended, if applicable, and the } \\
\text { corresponding address and location; } \\
\text { C. Offense history; }\end{array}$ \\
\hline
\end{tabular}

** Denotes those states where sex offender registration is required for convictions under the staff sexual misconduct laws of the states. Staff and inmates could also be required to register as sex offenders if the offense were charged under other registrable offenses.

This publication is developed by the NIC/WCL Project on Addressing Prison Rape under NIC Cooperative Agreement 06S20GJJ1.

This is not to be posted or reproduced without permission from the authors.

American University, Washington College of Law

Current as of August 2009 


\section{Fifty State Survey of Adult Sex Offender Registration Requirements}

\section{NIC/WCL Project on Addressing Prison Rape}

\begin{tabular}{|c|c|}
\hline $\begin{array}{l}\text { Information Maintained in } \\
\text { Sex Offender Registry } \\
\text { Cont'd } \\
\text { (Maine) }\end{array}$ & $\begin{array}{l}\text { D. Notation of any treatment received for a mental abnormality or personality disorder; } \\
\text { E. A photograph and set of fingerprints; } \\
\text { F. A description of the offense for which the registrant was convicted, the date of conviction } \\
\text { and the sentence imposed; and } \\
\text { G. Any other information the bureau determines important. }\end{array}$ \\
\hline $\begin{array}{l}\text { Community Notification } \\
\text { and Websites } \\
\text { (Maine) }\end{array}$ & $\begin{array}{l}\text { 34-A M.R.S.A. } \$ 11221 \text { (West 2008) } \\
\text { 9. PUBLIC ACCESS TO INFORMATION. A. The bureau shall post on the Internet for public inspection } \\
\text { information concerning a registrant. } \\
\text { 12. LAW ENFORCEMENT AGENCY WEBSITE. A law enforcement agency may maintain its own sex offender } \\
\text { website and may make that information available for use by the public. } \\
\text { 34-A M.R.S.A. } § 11255 \text { (West 2008) } \\
\text { 1. DEPARTMENT. Upon the conditional release or discharge of a registrant from a state correctional institution, } \\
\text { the department shall give notice to members of the public the department determines appropriate to ensure public } \\
\text { safety. } \\
\text { 2. LAW ENFORCEMENT AGENCIES. Upon receipt of the information concerning the conditional release or } \\
\text { discharge of a registrant, a law enforcement agency shall notify members of a municipality that the law enforcement } \\
\text { agency determines appropriate to ensure public safety. }\end{array}$ \\
\hline $\begin{array}{l}\text { Limitations on Residency or } \\
\text { Employment } \\
\text { (Maine) }\end{array}$ & None \\
\hline
\end{tabular}

** Denotes those states where sex offender registration is required for convictions under the staff sexual misconduct laws of the states. Staff and inmates could also be required to register as sex offenders if the offense were charged under other registrable offenses.

This publication is developed by the NIC/WCL Project on Addressing Prison Rape under NIC Cooperative Agreement 06S20GJJ1.

This is not to be posted or reproduced without permission from the authors.

American University, Washington College of Law

Current as of August 2009 


\section{Fifty State Survey of Adult Sex Offender Registration Requirements}

\section{NIC/WCL Project on Addressing Prison Rape}

\begin{tabular}{|c|c|}
\hline $\begin{array}{l}\text { Duration of Registration } \\
\text { (Maine) }\end{array}$ & $\begin{array}{l}\text { 34-A M.R.S.A. } \S \S 11225-\mathrm{A} \text { (West 2008) } \\
10 \text { years for sex offenders not subject to lifetime registration. } \\
\text { 34-A M.R.S.A. } \S 11203 \text { (West } 2008 \text { ) } \\
\text { Life for persons convicted of sexually violent offenses or for registrants with prior sex offense convictions. }\end{array}$ \\
\hline $\begin{array}{l}\text { Registrable Offenses } \\
\text { (Maryland) }\end{array}$ & 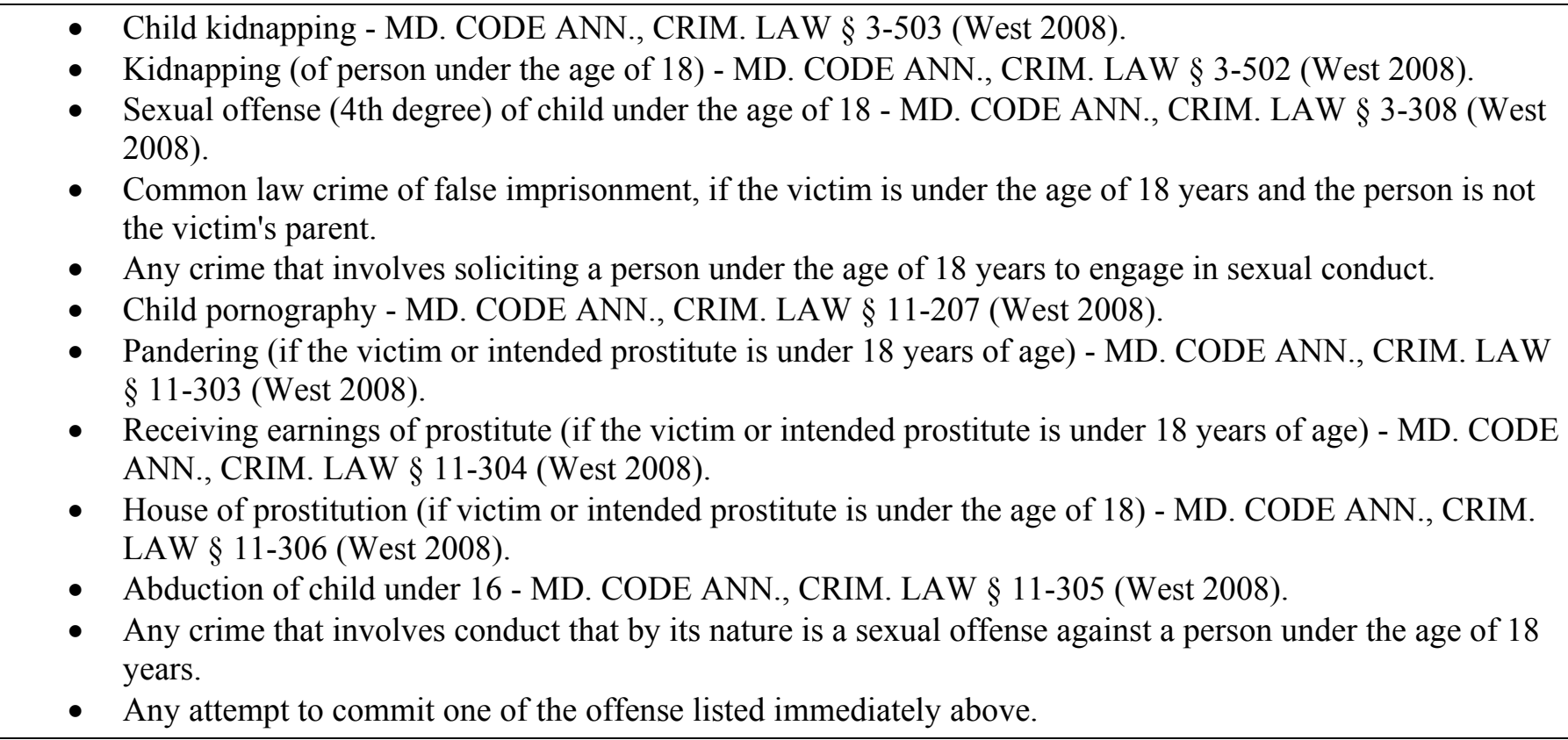 \\
\hline
\end{tabular}

** Denotes those states where sex offender registration is required for convictions under the staff sexual misconduct laws of the states. Staff and inmates could also be required to register as sex offenders if the offense were charged under other registrable offenses.

This publication is developed by the NIC/WCL Project on Addressing Prison Rape under NIC Cooperative Agreement 06S20GJJ1.

This is not to be posted or reproduced without permission from the authors.

American University, Washington College of Law

Current as of August 2009 


\section{Fifty State Survey of Adult Sex Offender Registration Requirements}

\section{NIC/WCL Project on Addressing Prison Rape}

\begin{tabular}{|c|c|}
\hline $\begin{array}{l}\text { Registrable Offenses Cont'd } \\
\text { (Maryland) }\end{array}$ & $\begin{array}{l}\text { - Crimes resulting in conviction in another state or in a federal, military, or Native American tribal court of a } \\
\text { crime that, if committed in this State, would constitute one of the crimes listed (including attempt). } \\
\text { The following offenses require registration as a Sexually Violent Offender: } \\
\text { - Rape (1st degree) - MD. CODE ANN., CRIM. LAW } \S 3-303 \text { (West 2008). } \\
\text { - Rape (2nd degree) - MD. CODE ANN., CRIM. LAW } \S 3-304 \text { (West 2008). } \\
\text { - Sexual offense (1st degree) - MD. CODE ANN., CRIM. LAW } \S 3-305 \text { (West 2008). } \\
\text { - Sexual offense (2nd degree) - MD. CODE ANN., CRIM. LAW } \S 3-306 \text { (West 2008). } \\
\text { - Sexual offense (3rd degree) - MD. CODE ANN., CRIM. LAW } \S 3-307 \text { (West 2008). } \\
\text { - Attempted rape (1st degree) - MD. CODE ANN., CRIM. LAW } \S 3-309 \text { (West 2008). } \\
\text { - Attempted rape (2nd degree) - MD. CODE ANN., CRIM. LAW } \S 3-310 \text { (West 2008). } \\
\text { - Attempted sexual offense (1st degree) - MD. CODE ANN., CRIM. LAW } \S 3-311 \text { (West 2008). } \\
\text { - Attempted sexual offense (2nd degree) - MD. CODE ANN., CRIM. LAW } \S 3-312 \text { (West 2008). } \\
\text { - Crimes resulting in conviction in another state or in a federal, military, or Native American tribal court of a } \\
\text { crime that, if committed in this State, would constitute one of the crimes listed. }\end{array}$ \\
\hline $\begin{array}{l}\text { Sex Offender Registration } \\
\text { Required for Staff Sexual } \\
\text { Misconduct? } \\
\text { (Maryland) }\end{array}$ & NO \\
\hline $\begin{array}{l}\text { Information Maintained in } \\
\text { Sex Offender Registry } \\
\text { (Maryland) }\end{array}$ & $\begin{array}{l}\text { MD. CRIM. PROC. } \S 11-706 \text { (WEST 2008) } \\
\text { (a) A registration statement shall include: } \\
\text { (1) the registrant's full name, including any suffix, and address; } \\
\text { (2) (i) for a registrant under } \S 11-704(a)(7)(\mathrm{i}) \text { of this subtitle or who is on work release, the registrant's place of } \\
\text { employment; or (ii) for a registrant under } \S 11-704(\mathrm{a})(7)(\mathrm{ii}) \text { of this subtitle, the registrant's place of }\end{array}$ \\
\hline
\end{tabular}

** Denotes those states where sex offender registration is required for convictions under the staff sexual misconduct laws of the states. Staff and inmates could also be required to register as sex offenders if the offense were charged under other registrable offenses.

This publication is developed by the NIC/WCL Project on Addressing Prison Rape under NIC Cooperative Agreement 06S20GJJ1.

This is not to be posted or reproduced without permission from the authors.

American University, Washington College of Law

Current as of August 2009 


\section{Fifty State Survey of Adult Sex Offender Registration Requirements}

\section{NIC/WCL Project on Addressing Prison Rape}

\begin{tabular}{|c|c|}
\hline $\begin{array}{l}\text { Information Maintained in } \\
\text { Sex Offender Registry } \\
\text { Cont'd } \\
\text { (Maryland) }\end{array}$ & $\begin{array}{l}\text { (3) (i) for a registrant enrolled, or expecting to enroll, in an institution of higher education in the State as a full- } \\
\text { time or part-time student, the name and address of the institution of higher education; or (ii) for a registrant } \\
\text { who carries on employment, or expects to carry on employment, at an institution of higher education in the } \\
\text { State, the name and address of the institution of higher education; } \\
\text { (4) a description of the crime for which the registrant was convicted } \\
\text { (5) the date that the registrant was convicted; } \\
\text { (6) the jurisdiction in which the registrant was convicted; } \\
\text { (7) a list of any aliases, former names, electronic mail addresses, computer log-in or screen names or identities, } \\
\text { instant-messaging identities, and electronic chat room identities that the registrant has used; } \\
\text { (8) the registrant's Social Security number; } \\
\text { (9) any other name by which the registrant has been legally known; } \\
\text { (10) a copy of the registrant's valid driver's license or identification card; } \\
\text { (11) the license plate number and description of any vehicle owned or regularly operated by the registrant; and } \\
\text { (12) the registrant's signature and date signed. } \\
\text { (b) If the registrant is a sexually violent predator, the registration statement shall also include: } \\
\text { (1) identifying factors, including a physical description; } \\
\text { (2) anticipated future residence, if known at the time of registration; } \\
\text { (3) offense history; and } \\
\text { (4) documentation of treatment received for a mental abnormality or personality disorder. }\end{array}$ \\
\hline $\begin{array}{l}\text { Community Notification } \\
\text { and Websites } \\
\text { (Maryland) }\end{array}$ & $\begin{array}{l}\text { MD. CRIM. PROC. } § \S 11-717 \text { (WEST 2008) } \\
\text { (a) Department to make available registration statements; excluded information. -- } \\
\text { (1) The Department shall make available to the public registration statements or information about registration } \\
\text { statements. } \\
\text { (2) Information about registration statements shall include, in plain language that can be understood without } \\
\text { special knowledge of the criminal laws of the State, a description of the crime of the offender that is the basis for } \\
\text { the registration, excluding details that would identify the victim. }\end{array}$ \\
\hline
\end{tabular}

** Denotes those states where sex offender registration is required for convictions under the staff sexual misconduct laws of the states. Staff and 101 inmates could also be required to register as sex offenders if the offense were charged under other registrable offenses.

This publication is developed by the NIC/WCL Project on Addressing Prison Rape under NIC Cooperative Agreement 06S20GJJ1.

This is not to be posted or reproduced without permission from the authors.

American University, Washington College of Law

Current as of August 2009 


\section{Fifty State Survey of Adult Sex Offender Registration Requirements}

\section{NIC/WCL Project on Addressing Prison Rape}

\begin{tabular}{|c|c|}
\hline $\begin{array}{l}\text { Community Notification } \\
\text { and Websites Cont'd } \\
\text { (Maryland) }\end{array}$ & $\begin{array}{l}\text { (b) Posting on Internet. -- The Department may post on the Internet a current listing of each registrant's name, } \\
\text { crime, and other identifying information. } \\
\text { MD. CRIM. PROC. } § ~ \\
\end{array}$ \\
\hline $\begin{array}{l}\text { Limitations on Residency or } \\
\text { Employment } \\
\text { (Maryland) }\end{array}$ & None. \\
\hline
\end{tabular}

** Denotes those states where sex offender registration is required for convictions under the staff sexual misconduct laws of the states. Staff and 102 inmates could also be required to register as sex offenders if the offense were charged under other registrable offenses.

This publication is developed by the NIC/WCL Project on Addressing Prison Rape under NIC Cooperative Agreement 06S20GJJ1.

This is not to be posted or reproduced without permission from the authors.

American University, Washington College of Law

Current as of August 2009 


\section{Fifty State Survey of Adult Sex Offender Registration Requirements}

\section{NIC/WCL Project on Addressing Prison Rape}

\begin{tabular}{|c|c|}
\hline \multicolumn{2}{|r|}{ MASSACHUSETTS } \\
\hline $\begin{array}{l}\text { Registrable Offenses } \\
\text { (Massachusetts) }\end{array}$ & 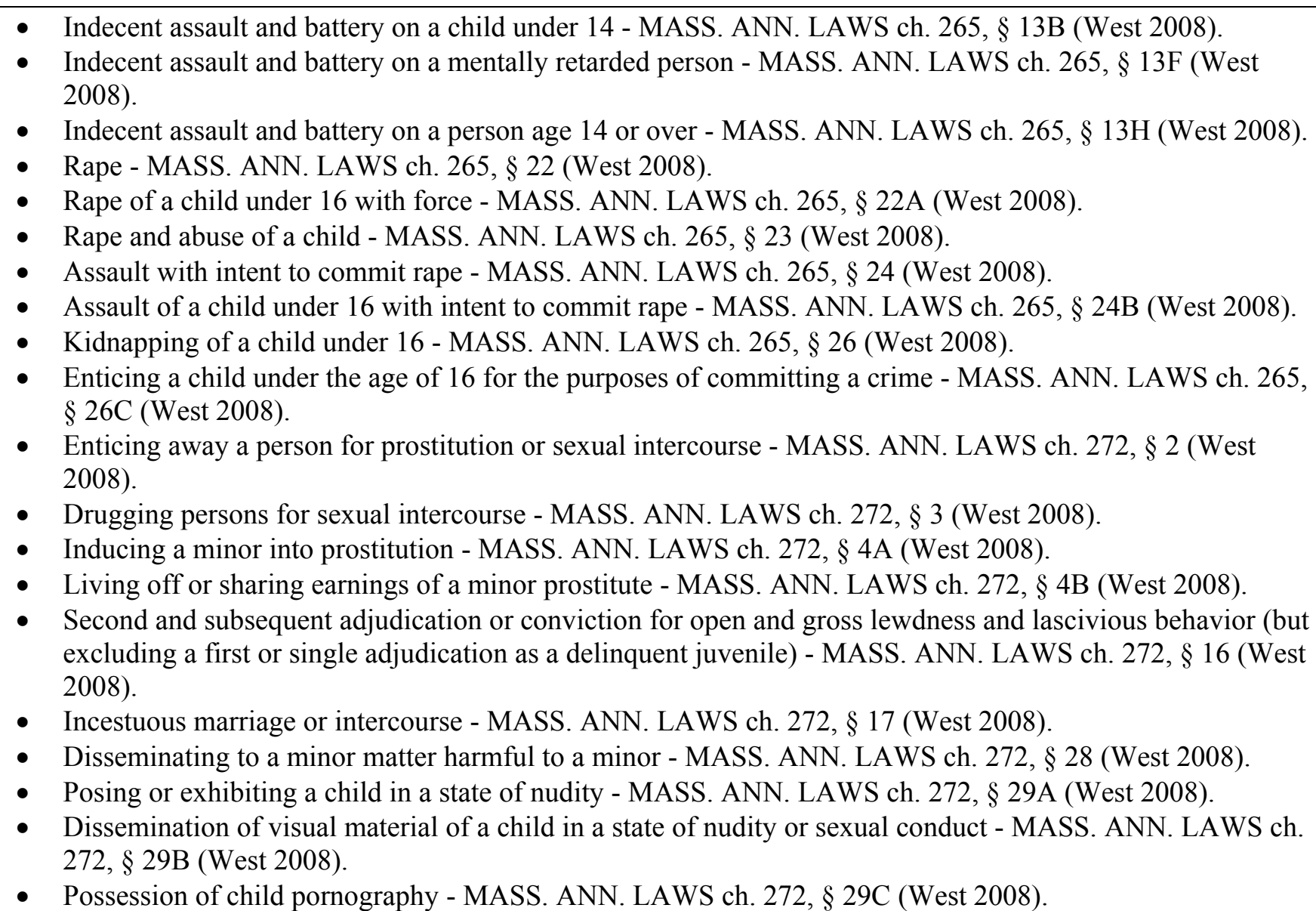 \\
\hline
\end{tabular}

** Denotes those states where sex offender registration is required for convictions under the staff sexual misconduct laws of the states. Staff and 103 inmates could also be required to register as sex offenders if the offense were charged under other registrable offenses.

This publication is developed by the NIC/WCL Project on Addressing Prison Rape under NIC Cooperative Agreement 06S20GJJ1.

This is not to be posted or reproduced without permission from the authors.

American University, Washington College of Law

Current as of August 2009 


\section{Fifty State Survey of Adult Sex Offender Registration Requirements}

\section{NIC/WCL Project on Addressing Prison Rape}

\begin{tabular}{|c|c|}
\hline $\begin{array}{l}\text { Registrable Offenses Cont'd } \\
\text { (Massachusetts) }\end{array}$ & $\begin{array}{l}\text { - Unnatural and lascivious acts with a child under } 16 \text { - MASS. ANN. LAWS ch. 272, } \S 35 \text { A (West 2008). } \\
\text { - Aggravated rape - MASS. ANN. LAWS ch. 277, } \S 39 \text { (West 2008). } \\
\text { - Any attempt to commit a violation of any of the aforementioned sections. } \\
\text { authority. }\end{array}$ \\
\hline $\begin{array}{l}\text { Sex Offender Registration } \\
\text { Required for Staff Sexual } \\
\text { Misconduct? } \\
\text { (Massachusetts) }\end{array}$ & NO \\
\hline $\begin{array}{l}\text { Information Maintained in } \\
\text { Sex Offender Registry } \\
\text { (Massachusetts) }\end{array}$ & $\begin{array}{l}\text { M.G.L.A. } 6 \S 178 \mathrm{D} \text { (West 2008) } \\
\text { (a) the sex offender's name, aliases used, date and place of birth, sex, race, height, weight, eye and hair color, } \\
\text { social security number, home address, any secondary addresses and work address and, if the sex offender } \\
\text { works at or attends an institution of higher learning, the name and address of the institution; } \\
\text { (b) a photograph and set of fingerprints; } \\
\text { (c) a description of the offense for which the sex offender was convicted or adjudicated, the city or town where } \\
\text { the offense occurred, the date of conviction or adjudication and the sentence imposed; } \\
\text { (d) any other information which may be useful in assessing the risk of the sex offender to reoffend; and } \\
\text { (e) any other information which may be useful in identifying the sex offender. }\end{array}$ \\
\hline $\begin{array}{l}\text { Community Notification } \\
\text { and Websites } \\
\text { (Massachusetts) }\end{array}$ & $\begin{array}{l}\text { M.G.L.A. } 6 \S 178 \text { F } 1 / 2 \text { (West 2008) } \\
\text { - Any person who is } 18 \text { years of age or older and who states that he is requesting sex offender registry information } \\
\text { for his own protection or for the protection of a child under the age of } 18 \text { or another person for whom the } \\
\text { requesting person has responsibility, care or custody shall receive at no cost from the board a report which } \\
\text { indicates whether an individual identified by name, date of birth or sufficient personal identifying characteristics } \\
\text { is a sex offender with an obligation to register, the offenses for which he was convicted or adjudicated and the } \\
\text { dates of such convictions or adjudications. }\end{array}$ \\
\hline
\end{tabular}

** Denotes those states where sex offender registration is required for convictions under the staff sexual misconduct laws of the states. Staff and 104 inmates could also be required to register as sex offenders if the offense were charged under other registrable offenses.

This publication is developed by the NIC/WCL Project on Addressing Prison Rape under NIC Cooperative Agreement 06S20GJJ1.

This is not to be posted or reproduced without permission from the authors.

American University, Washington College of Law

Current as of August 2009 


\section{Fifty State Survey of Adult Sex Offender Registration Requirements}

\section{NIC/WCL Project on Addressing Prison Rape}

\begin{tabular}{|c|c|}
\hline $\begin{array}{l}\text { Community Notification } \\
\text { and Websites Cont'd } \\
\text { (Massachusetts) }\end{array}$ & $\begin{array}{l}\text { - Information about an offender shall be made available pursuant to this section only if the offender is a sex } \\
\text { offender who has been finally classified by the board as a level } 2 \text { or level } 3 \text { sex offender. } \\
\text { M.G.L.A. } 6 \S 178 \mathrm{D} \text { (West } 2008 \text { ) } \\
\text { - The board shall make the sex offender information contained in the sex offender registry, available for inspection } \\
\text { by the general public in the form of a comprehensive database published on the internet, known as the "sex } \\
\text { offender internet database"; } \\
\text { - Provided, however, that no registration data relating to a sex offender given a level } 1 \text { or level } 2 \text { designation by the } \\
\text { board shall be published in the sex offender internet database but may be disseminated by the board as otherwise } \\
\text { permitted. }\end{array}$ \\
\hline $\begin{array}{l}\text { Limitations on Residency or } \\
\text { Employment } \\
\text { (Massachusetts) }\end{array}$ & None. \\
\hline $\begin{array}{l}\text { Duration of Registration } \\
\text { (Massachusetts) }\end{array}$ & $\begin{array}{l}\text { M.G.L.A. } 6 \S 178 \mathrm{G} \text { (West } 2008 \text { ) } \\
20 \text { years for registrants not subject to lifetime registration. } \\
\text { Life for registrants: } \\
\text { - With } 2 \text { or more sex offense convictions; } \\
\text { - Convicted of a sexually violent offense; } \\
\text { - That have been determined to be sexually violent predators; or } \\
\text { - That the Sex Offender Registry Board has deemed a lifetime registrant. }\end{array}$ \\
\hline
\end{tabular}

** Denotes those states where sex offender registration is required for convictions under the staff sexual misconduct laws of the states. Staff and 105 inmates could also be required to register as sex offenders if the offense were charged under other registrable offenses.

This publication is developed by the NIC/WCL Project on Addressing Prison Rape under NIC Cooperative Agreement 06S20GJJ1.

This is not to be posted or reproduced without permission from the authors.

American University, Washington College of Law

Current as of August 2009 


\section{Fifty State Survey of Adult Sex Offender Registration Requirements}

\section{NIC/WCL Project on Addressing Prison Rape}

\begin{tabular}{|c|c|}
\hline \multicolumn{2}{|r|}{ MICHIGAN } \\
\hline $\begin{array}{l}\text { Registrable Offenses } \\
\text { (Michigan) }\end{array}$ & 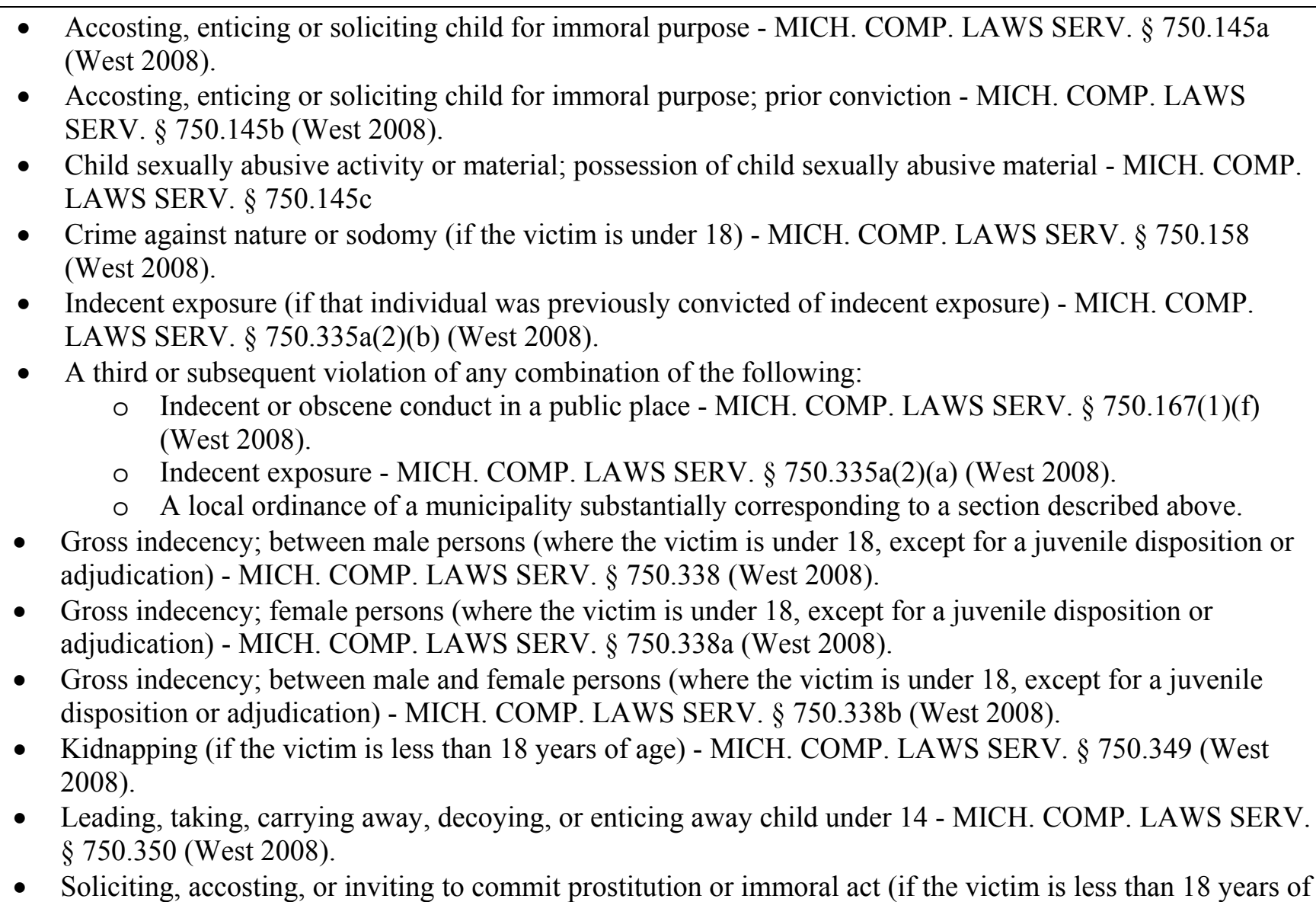 \\
\hline
\end{tabular}

** Denotes those states where sex offender registration is required for convictions under the staff sexual misconduct laws of the states. Staff and 106 inmates could also be required to register as sex offenders if the offense were charged under other registrable offenses.

This publication is developed by the NIC/WCL Project on Addressing Prison Rape under NIC Cooperative Agreement 06S20GJJ1.

This is not to be posted or reproduced without permission from the authors.

American University, Washington College of Law

Current as of August 2009 


\section{Fifty State Survey of Adult Sex Offender Registration Requirements}

\section{NIC/WCL Project on Addressing Prison Rape}

\begin{tabular}{|c|c|}
\hline $\begin{array}{l}\text { Registrable Offenses Cont'd } \\
\text { (Michigan) }\end{array}$ & 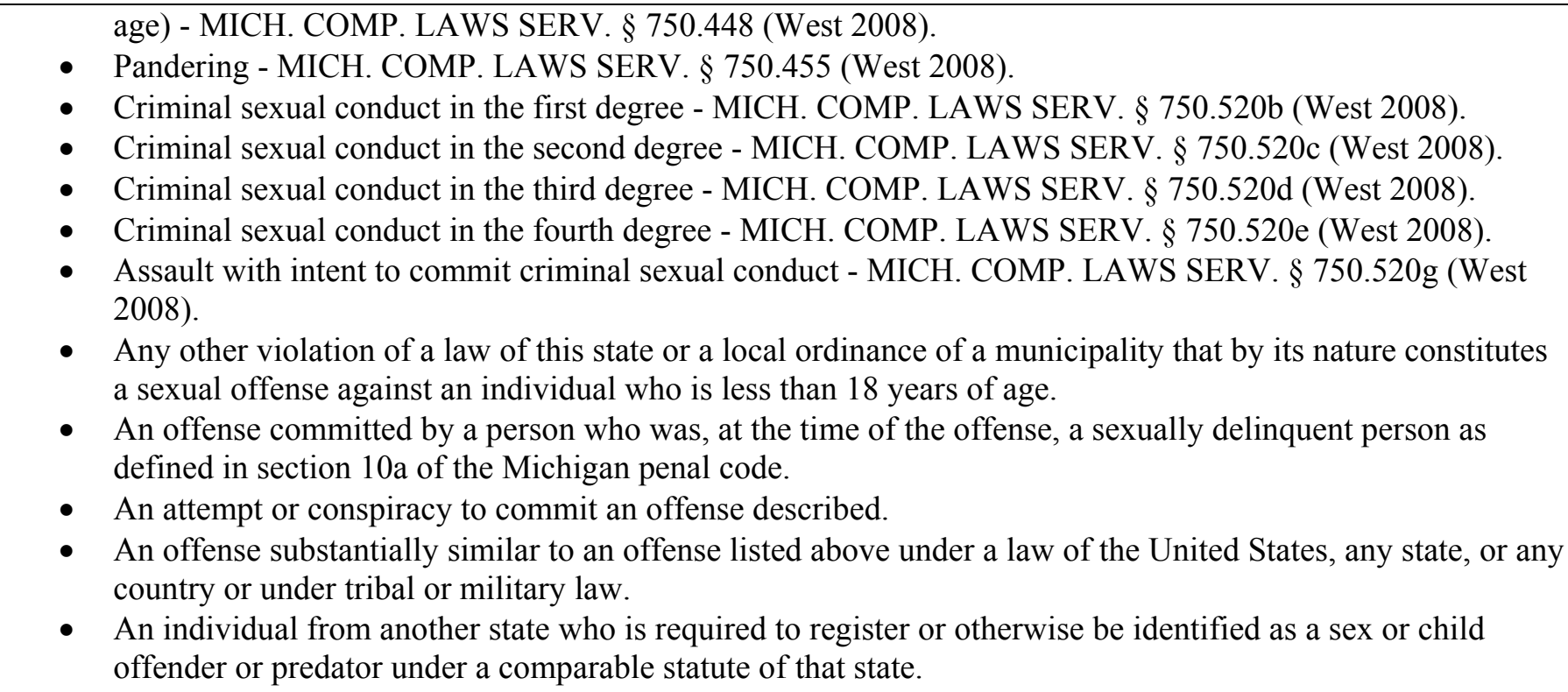 \\
\hline $\begin{array}{l}\text { Sex Offender Registration } \\
\text { Required for Staff Sexual } \\
\text { Misconduct? } \\
\text { (Michigan) }\end{array}$ & NO \\
\hline $\begin{array}{l}\text { Information Maintained in } \\
\text { Sex Offender Registry } \\
\text { (Michigan) }\end{array}$ & $\begin{array}{l}\text { M.C.L.A. } \$ 28.727 \text { (West 2008) } \\
\S 7(1)(a) \text { The individual's name, social security number, date of birth, and address or expected address. An } \\
\text { individual who is in a witness protection and relocation program is only required to use the name and identifying } \\
\text { information reflecting his or her new identity in a registration under this act. The registration and compilation } \\
\text { databases shall not contain any information identifying the individual's prior identity or locale. The department shall }\end{array}$ \\
\hline
\end{tabular}

** Denotes those states where sex offender registration is required for convictions under the staff sexual misconduct laws of the states. Staff and 107 inmates could also be required to register as sex offenders if the offense were charged under other registrable offenses.

This publication is developed by the NIC/WCL Project on Addressing Prison Rape under NIC Cooperative Agreement 06S20GJJ1.

This is not to be posted or reproduced without permission from the authors.

American University, Washington College of Law

Current as of August 2009 


\section{Fifty State Survey of Adult Sex Offender Registration Requirements}

\section{NIC/WCL Project on Addressing Prison Rape}

\begin{tabular}{|c|c|}
\hline $\begin{array}{l}\text { Information Maintained in } \\
\text { Sex Offender Registry } \\
\text { Cont'd } \\
\text { (Michigan) }\end{array}$ & $\begin{array}{l}\text { request each individual to provide his or her date of birth if it is not included in the registration, and that individual } \\
\text { shall comply with the request within } 10 \text { days. } \\
\text { (b) A brief summary of the individual's convictions for listed offenses regardless of when the conviction occurred, } \\
\text { including where the offense occurred and the original charge if the conviction was for a lesser offense. } \\
\text { (c) A complete physical description of the individual. } \\
\text { (d) The photograph required under section } 5 . \\
\text { (e) The individual's fingerprints if not already on file with the department. }\end{array}$ \\
\hline $\begin{array}{l}\text { Community Notification } \\
\text { and Websites } \\
\text { (Michigan) }\end{array}$ & $\begin{array}{l}\text { M.C.L.A. } \$ 28.730 \text { (West 2008) } \\
\text { (2): A department post, local law enforcement agency, or sheriff's department shall make information for the zip } \\
\text { code areas located in whole or in part within the post's, agency's, or sheriff's department's jurisdiction available for } \\
\text { public inspection during regular business hours. } \\
\text { (3): } \\
\text { - The department may make information available to the public through electronic, computerized, or other } \\
\text { accessible means. } \\
\text { - The department shall provide for notification by electronic or computerized means to any member of the public } \\
\text { who has subscribed in a manner required by the department when an individual initially registers under this act, } \\
\text { or changes his or her registration under this act, to a location that is in a zip code area designated by the } \\
\text { subscribing member of the public. } \\
\text { M.C.L.A. } \$ 28.728 \text { (West 2008) } \\
\text { (2) The department shall maintain a computerized database that consists of a compilation of individuals registered } \\
\text { under this act. }\end{array}$ \\
\hline
\end{tabular}

** Denotes those states where sex offender registration is required for convictions under the staff sexual misconduct laws of the states. Staff and inmates could also be required to register as sex offenders if the offense were charged under other registrable offenses.

This publication is developed by the NIC/WCL Project on Addressing Prison Rape under NIC Cooperative Agreement 06S20GJJ1.

This is not to be posted or reproduced without permission from the authors.

American University, Washington College of Law

Current as of August 2009 


\section{Fifty State Survey of Adult Sex Offender Registration Requirements}

\section{NIC/WCL Project on Addressing Prison Rape}

\begin{tabular}{|c|c|}
\hline $\begin{array}{l}\text { Community Notification } \\
\text { and Websites Cont'd } \\
\text { (Michigan) }\end{array}$ & $\begin{array}{l}\text { (6): } \\
\text { - The department shall make the compilation or information from the compilation available to a department post, } \\
\text { local law enforcement agency, sheriff's department, and the public by electronic, computerized, or other similar } \\
\text { means accessible to the post, agency, or sheriff's department. } \\
\text { - The electronic, computerized, or other similar means shall provide for both a search by name and by zip code. }\end{array}$ \\
\hline $\begin{array}{l}\text { Limitations on Residency or } \\
\text { Employment } \\
\text { (Michigan) }\end{array}$ & $\begin{array}{l}\text { M.C.L.A. } \$ \S 28.733 \& 27.734(\text { West } 2008) \\
\text { Sex offenders may not work or loiter within a student safety zone. }\end{array}$ \\
\hline & MINNESOTA** \\
\hline
\end{tabular}

** Denotes those states where sex offender registration is required for convictions under the staff sexual misconduct laws of the states. Staff and inmates could also be required to register as sex offenders if the offense were charged under other registrable offenses.

This publication is developed by the NIC/WCL Project on Addressing Prison Rape under NIC Cooperative Agreement 06S20GJJ1.

This is not to be posted or reproduced without permission from the authors.

American University, Washington College of Law

Current as of August 2009 


\section{Fifty State Survey of Adult Sex Offender Registration Requirements}

\section{NIC/WCL Project on Addressing Prison Rape}

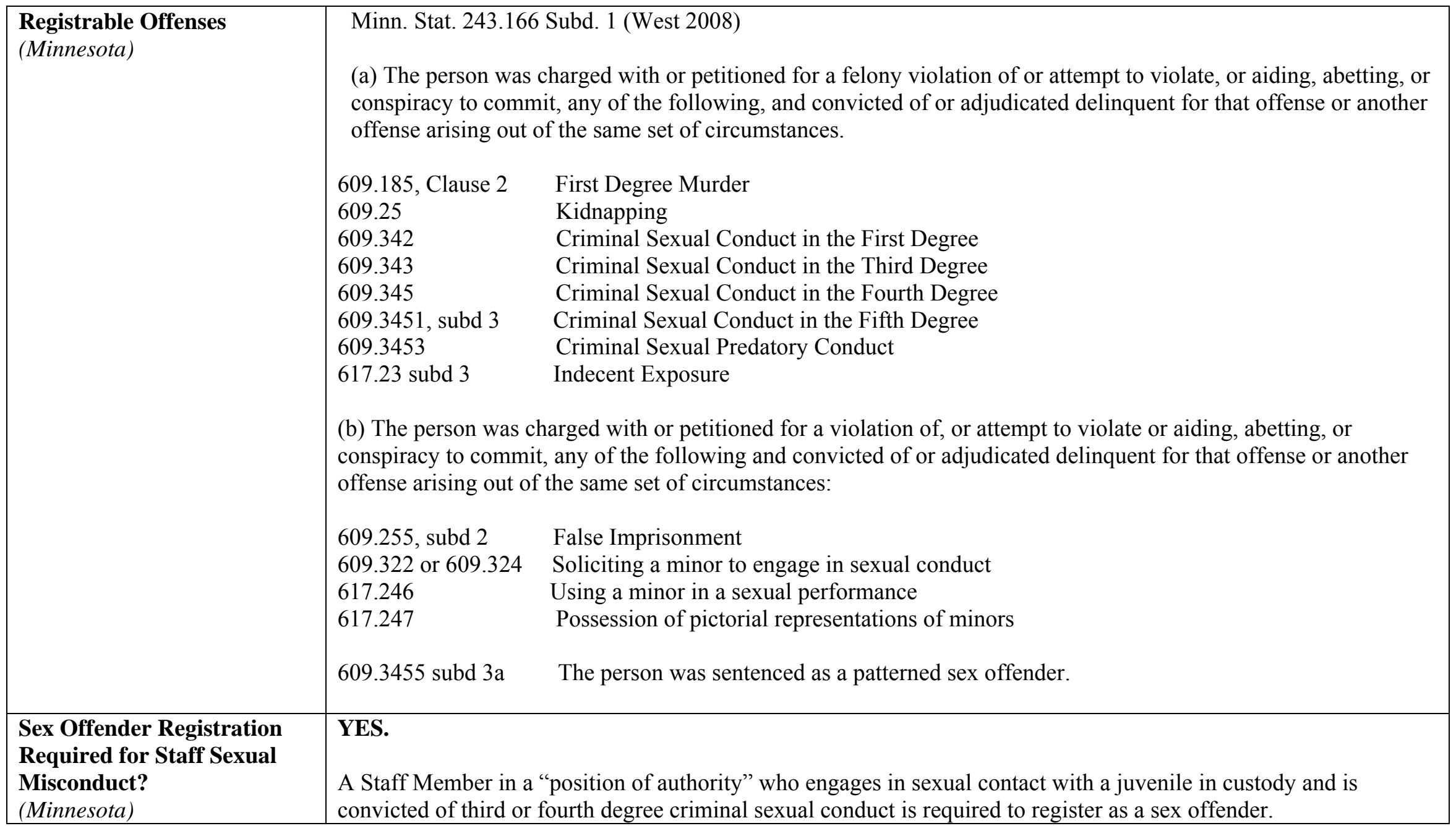

** Denotes those states where sex offender registration is required for convictions under the staff sexual misconduct laws of the states. Staff and 110 inmates could also be required to register as sex offenders if the offense were charged under other registrable offenses.

This publication is developed by the NIC/WCL Project on Addressing Prison Rape under NIC Cooperative Agreement 06S20GJJ1.

This is not to be posted or reproduced without permission from the authors.

American University, Washington College of Law

Current as of August 2009 


\section{Fifty State Survey of Adult Sex Offender Registration Requirements}

\section{NIC/WCL Project on Addressing Prison Rape}

\begin{tabular}{|c|c|}
\hline $\begin{array}{l}\text { Sex Offender Registration } \\
\text { Required for Staff Sexual } \\
\text { Misconduct? Cont'd } \\
\text { (Minnesota) }\end{array}$ & $\begin{array}{l}\text { Staff members in charge of juvenile wards are defined as being in a "position of authority" under criminal sexual } \\
\text { conduct. See, State v. Mogler, App. } 2006,719 \text { N.W.2d } 201 \text {. Constitutional Law } 4509(23) \text {, defining "position of } \\
\text { authority" as including police officers. } \\
2007 \text { MN H.F. } 829 \text { (NS) (West } 2008 \text { ) } \\
\text { Subdivision 1. Crime defined. A person who engages in sexual contact with another person is guilty of criminal } \\
\text { sexual conduct in the fourth degree if any of the following circumstances exists: } \\
\text { (b) the complainant is at least } 13 \text { but less than } 16 \text { years of age and the actor is more than } 48 \text { months older } \\
\text { than the complainant or in a position of authority over the complainant. Consent by the complainant to the } \\
\text { act is not a defense. In any such case, if the actor is no more than } 120 \text { months older than the complainant, it } \\
\text { shall be an affirmative defense which must be proved by a preponderance of the evidence that the actor } \\
\text { reasonably believes the complainant to be } 16 \text { years of age or older. In all other cases, mistake as to the } \\
\text { complainant's age shall not be a defense; } \\
\text { (d) the complainant is at least } 16 \text { but less than } 18 \text { years of age and the actor is more than } 48 \text { months older } \\
\text { than the complainant and in a position of authority over the complainant. Neither mistake as to the } \\
\text { complainant's age nor consent to the act by the complainant is a defense; } \\
\text { (i) the intentional touching by the actor of the complainant's intimate parts, or (ii) the touching by the } \\
\text { complainant of the actor's, the complainant's, or another's intimate parts effected by a person in a position of } \\
\text { authority, or by coercion, or by inducement if the complainant is under } 13 \text { years of age or mentally } \\
\text { impaired, or (iii) the touching by another of the complainant's intimate parts effected by coercion or by a } \\
\text { person in a position of authority, or (iv) in any of the cases above, the touching of the clothing covering the } \\
\text { immediate area of the intimate parts. } \\
\text { Sec. } 4 \text {. Minnesota Statutes } 2006 \text {, section } 609.344 \text {, subdivision } 1 \text {, is amended to read: }\end{array}$ \\
\hline
\end{tabular}

** Denotes those states where sex offender registration is required for convictions under the staff sexual misconduct laws of the states. Staff and inmates could also be required to register as sex offenders if the offense were charged under other registrable offenses.

This publication is developed by the NIC/WCL Project on Addressing Prison Rape under NIC Cooperative Agreement 06S20GJJ1.

This is not to be posted or reproduced without permission from the authors.

American University, Washington College of Law

Current as of August 2009 


\section{Fifty State Survey of Adult Sex Offender Registration Requirements}

\section{NIC/WCL Project on Addressing Prison Rape}

\begin{tabular}{|c|c|}
\hline $\begin{array}{l}\text { Sex Offender Registration } \\
\text { Required for Staff Sexual } \\
\text { Misconduct? Cont'd } \\
\text { (Minnesota) }\end{array}$ & $\begin{array}{l}\text { Subdivision 1. Crime defined. A person who engages in sexual penetration with another person is guilty of criminal } \\
\text { sexual conduct in the third degree if any of the following circumstances exists: } \\
\text { (e) the complainant is at least } 16 \text { but less than } 18 \text { years of age and the actor is more than } 48 \text { months older } \\
\text { than the complainant and in a position of authority over the complainant. Neither mistake as to the } \\
\text { complainant's age nor consent to the act by the complainant is a defense; }\end{array}$ \\
\hline $\begin{array}{l}\text { Information Maintained in } \\
\text { Sex Offender Registry } \\
\text { (Minnesota) }\end{array}$ & $\begin{array}{l}\text { M.S.A. } § 243.166 \text { (Subd. 4a) (West 2008) } \\
\text { - name } \\
\text { - primary address } \\
\text { - all secondary addresses in Minnesota including all addresses used or residential or recreational purposes } \\
\text { - fingerprints } \\
\text { - photograph } \\
\text { - all address of Minnesota property owned, leased or rented by the person } \\
\text { - addresses of all places of employment } \\
\text { - addresses of all school where the person is enrolled } \\
\text { - year, model, make, license plate number and color of all vehicles owned or regularly driven } \\
\text { - offense history and documentation of treatment received (if person has been deemed a sexually dangerous } \\
\text { person or has a sexual psychopathic personality) }\end{array}$ \\
\hline $\begin{array}{l}\text { Community Notification } \\
\text { and Websites } \\
\text { (Minnesota) }\end{array}$ & $\begin{array}{l}\text { M.S.A. } \$ 244.052 \text { (West 2008) } \\
\text { (b) The law enforcement agency shall employ the following guidelines in determining the scope of disclosure made } \\
\text { under this subdivision: } \\
\quad \text { (1) If the offender is assigned to risk level I, the agency may maintain information regarding the offender }\end{array}$ \\
\hline
\end{tabular}

** Denotes those states where sex offender registration is required for convictions under the staff sexual misconduct laws of the states. Staff and inmates could also be required to register as sex offenders if the offense were charged under other registrable offenses.

This publication is developed by the NIC/WCL Project on Addressing Prison Rape under NIC Cooperative Agreement 06S20GJJ1.

This is not to be posted or reproduced without permission from the authors.

American University, Washington College of Law

Current as of August 2009 


\section{Fifty State Survey of Adult Sex Offender Registration Requirements}

\section{NIC/WCL Project on Addressing Prison Rape}

\begin{tabular}{|c|c|}
\hline $\begin{array}{l}\text { Community Notification } \\
\text { and Websites Cont'd } \\
\text { (Minnesota) }\end{array}$ & $\begin{array}{l}\text { within the agency and may disclose it to other law enforcement agencies. Additionally, the agency may } \\
\text { disclose the information to any victims of or witnesses to the offense committed by the offender. The } \\
\text { agency shall disclose the information to victims of the offense committed by the offender who have } \\
\text { requested disclosure and to adult members of the offender's immediate household; } \\
\text { (2) If the offender is assigned to risk level II, the agency also may disclose the information to agencies and } \\
\text { groups that the offender is likely to encounter for the purpose of securing those institutions and protecting } \\
\text { individuals in their care while they are on or near the premises of the institution. These agencies and groups } \\
\text { include the staff members of public and private educational institutions, day care establishments, and } \\
\text { establishments and organizations that primarily serve individuals likely to be victimized by the offender. } \\
\text { The agency also may disclose the information to individuals the agency believes are likely to be victimized } \\
\text { by the offender; } \\
\text { (3) If the offender is assigned to risk level III, the agency shall disclose the information to the persons and } \\
\text { entities described in clauses (1) and (2) and to other members of the community whom the offender is likely } \\
\text { to encounter. } \\
\text { (c) "likely to encounter" means that: } \\
\text { (1) The organizations or community members are in a location or in close proximity to a location where the } \\
\text { offender lives or is employed, or which the offender visits or is likely to visit on a regular basis, other than } \\
\text { the location of the offender's outpatient treatment program; and } \\
\text { (2) The types of interaction which ordinarily occur at that location and other circumstances indicate that } \\
\text { contact with the offender is reasonably certain. } \\
\text { Subd. } 4 \text { b. The commissioner of corrections shall create and maintain an Internet Web site and post on the site the } \\
\text { information about offenders assigned to risk level III forwarded by law enforcement. }\end{array}$ \\
\hline $\begin{array}{l}\text { Limitations on Residency or } \\
\text { Employment } \\
\text { (Minnesota) }\end{array}$ & None. \\
\hline
\end{tabular}

** Denotes those states where sex offender registration is required for convictions under the staff sexual misconduct laws of the states. Staff and 113 inmates could also be required to register as sex offenders if the offense were charged under other registrable offenses.

This publication is developed by the NIC/WCL Project on Addressing Prison Rape under NIC Cooperative Agreement 06S20GJJ1.

This is not to be posted or reproduced without permission from the authors.

American University, Washington College of Law

Current as of August 2009 


\section{Fifty State Survey of Adult Sex Offender Registration Requirements}

\section{NIC/WCL Project on Addressing Prison Rape}

\begin{tabular}{|c|c|}
\hline $\begin{array}{l}\text { Duration of Registration } \\
\text { (Minnesota) }\end{array}$ & $\begin{array}{l}\text { M.S.A. } \$ 243.166 \text { (West 2008) } \\
\text { Subd. 6. } 10 \text { years for sex offenders not subject to lifetime registration. } \\
\text { Subd. 1.b. Life for persons: } \\
\text { - With prior convictions or adjudications for sex offenses; } \\
\text { - Found to have caused the death of a human while committing First or Second degree criminal sexual conduct; } \\
\text { - Convicted for engaging in sexual penetration or sexual contact with a person under } 13 \text { if the offender: } \\
\text { O was more than } 36 \text { months older than the victim } \\
\text { o was armed with a dangerous weapon; } \\
\text { o causes personal injury to the victim by using force or by knowing that the victim is mentally impaired, } \\
\text { mentally incapacitated or physically helpless } \\
\text { o aided or abetted } 1 \text { or more accomplices; } \\
\text { o was under } 16 \text { at the time of the offense, had a significant relationship to the victim and used force or coercion, } \\
\text { the victim suffered personal injury, or the abuse was committed over an extended period of time. }\end{array}$ \\
\hline & MISSISSIPPI \\
\hline $\begin{array}{l}\text { Registrable Offenses } \\
\text { (Mississippi) }\end{array}$ & $\begin{array}{l}\text { - Kidnapping (if the victim was below the age of 18) - MISS. CODE ANN. } \S 97-3-53 \text { (West 2008). } \\
\text { - Statutory rape (except conviction or adjudication under MISS. CODE ANN. 97-3-65(1)(a) (West 2008), } \\
\text { when the offender was } 18 \text { years of age or younger at the time of the alleged offense, is not be a registrable } \\
\text { sex offense) - MISS. CODE ANN. } \$ 97-3-53 \text { (West 2008). } \\
\text { - Rape; assault with intent to ravish - MISS. CODE ANN. } \S 97-3-71 \text { (West 2008). } \\
\text { - Sexual battery (except, conviction or adjudication under Section 97-3-95(1) (c), when the offender was } 18 \\
\text { years of age or younger at the time of the alleged offense, is not be a registrable sex offense) - MISS. } \\
\text { CODE ANN. } \S 97-3-95 \text { (West 2008). } \\
\text { Enticing child for concealment, prostitution or marriage - MISS. CODE ANN. } \S 97-5-5 \text { (West 2008). }\end{array}$ \\
\hline
\end{tabular}

** Denotes those states where sex offender registration is required for convictions under the staff sexual misconduct laws of the states. Staff and 114 inmates could also be required to register as sex offenders if the offense were charged under other registrable offenses.

This publication is developed by the NIC/WCL Project on Addressing Prison Rape under NIC Cooperative Agreement 06S20GJJ1.

This is not to be posted or reproduced without permission from the authors.

American University, Washington College of Law

Current as of August 2009 


\section{Fifty State Survey of Adult Sex Offender Registration Requirements}

\section{NIC/WCL Project on Addressing Prison Rape}

\begin{tabular}{|c|c|}
\hline $\begin{array}{l}\text { Registrable Offenses Cont'd } \\
\text { (Mississippi) }\end{array}$ & 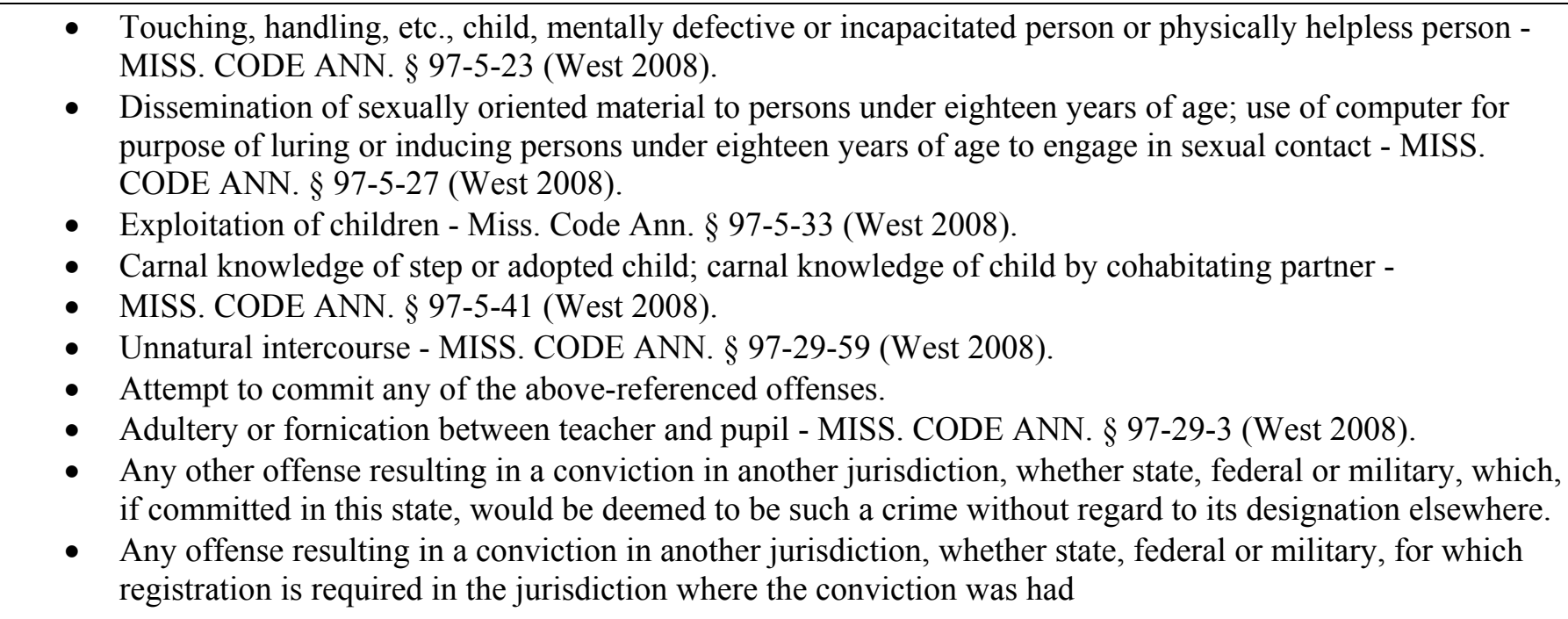 \\
\hline $\begin{array}{l}\text { Information Maintained in } \\
\text { Sex Offender Registry } \\
\text { (Mississippi) }\end{array}$ & $\begin{array}{l}\text { MISS. CODE ANN. §45-33-25 (West 2008) } \\
\text { (2) Any person required to register under this chapter shall submit the following information at the time of } \\
\text { registration: } \\
\text { (a) Name, including a former name which has been legally changed; } \\
\text { (b) Street address of all current permanent and temporary residences within state or out of state } \\
\text { (c) Date, place and address of employment; } \\
\text { (d) Crime for which convicted; }\end{array}$ \\
\hline
\end{tabular}

** Denotes those states where sex offender registration is required for convictions under the staff sexual misconduct laws of the states. Staff and inmates could also be required to register as sex offenders if the offense were charged under other registrable offenses.

This publication is developed by the NIC/WCL Project on Addressing Prison Rape under NIC Cooperative Agreement 06S20GJJ1.

This is not to be posted or reproduced without permission from the authors.

American University, Washington College of Law

Current as of August 2009 


\section{Fifty State Survey of Adult Sex Offender Registration Requirements}

\section{NIC/WCL Project on Addressing Prison Rape}

\begin{tabular}{|c|c|}
\hline $\begin{array}{l}\text { Information Maintained in } \\
\text { Sex Offender Registry } \\
\text { Cont'd } \\
\text { (Mississippi) }\end{array}$ & $\begin{array}{l}\text { (e) Date and place of conviction, adjudication or acquittal by reason of insanity; } \\
\text { (f) Aliases used; } \\
\text { (g) Social security number; } \\
\text { (h) Date and place of birth; } \\
\text { (i) Age, race, sex, height, weight, hair and eye colors, and any other physical description or identifying factors } \\
\text { (j) A brief description of the offense or offenses for which the registration is required } \\
\text { (k) Driver's license or state identification card number, which license or card may be electronically accessed by } \\
\text { the Department of Public Safety; } \\
\text { (l) Anticipated future residence; } \\
\text { (m) If the registrant's residence is a motor vehicle, trailer, mobile home or manufactured home, the registrant } \\
\text { shall also provide vehicle identification number, license tag number, registration number and a description, } \\
\text { including color scheme, of the motor vehicle, trailer, mobile home or manufactured home: if the registrant's } \\
\text { place of residence is a vessel or houseboat, the registrant shall also provide the hull identification number, } \\
\text { manufacturer's serial number, name of the vessel or houseboat, registration number and a description, } \\
\text { including color scheme, of the vessel or houseboat; } \\
\text { (n) Vehicle make, model, color and license tag number; } \\
\text { (o) Offense history; } \\
\text { (p) Photograph; } \\
\text { (q) Fingerprints and palm prints; } \\
\text { (r) Documentation of any treatment received for any mental abnormality or personality disorder of the person; } \\
\text { (s) Biological sample; } \\
\text { (t) Name of any public or private educational institution, including any secondary school, trade or professional } \\
\text { institution or institution of higher education at which the offender is employed, carries on a vocation (with or } \\
\text { without compensation) or is enrolled as a student, and the registrant's status; } \\
\text { (u) Copy of conviction or sentencing order for the sex offense for which registration is required; } \\
\text { (v) The offender's parole, probation or supervised release status and the existence of any outstanding arrest } \\
\text { warrants; } \\
\text { (w) Every online identity, screen name or username used, registered or created by a registrant; and } \\
\text { (x) Any other information deemed necessary. }\end{array}$ \\
\hline
\end{tabular}

** Denotes those states where sex offender registration is required for convictions under the staff sexual misconduct laws of the states. Staff and inmates could also be required to register as sex offenders if the offense were charged under other registrable offenses.

This publication is developed by the NIC/WCL Project on Addressing Prison Rape under NIC Cooperative Agreement 06S20GJJ1.

This is not to be posted or reproduced without permission from the authors.

American University, Washington College of Law

Current as of August 2009 


\section{Fifty State Survey of Adult Sex Offender Registration Requirements}

\section{NIC/WCL Project on Addressing Prison Rape}

\begin{tabular}{|c|c|}
\hline $\begin{array}{l}\text { Community Notification } \\
\text { and Websites } \\
\text { (Mississippi) }\end{array}$ & $\begin{array}{l}\text { MISS. CODE ANN. } § 45-33-49 \text { (West 2008) } \\
\text { (1) Records maintained pursuant to this chapter shall be open to law enforcement agencies which shall be } \\
\text { authorized to release relevant and necessary information regarding sex offenders to the public. } \\
\text { (4) Upon written request, the department may also provide to any person the: } \\
\text { - name, } \\
\text { - address, photograph, if available, } \\
\text { - date of photograph, } \\
\text { - place of employment, } \\
\text { - crime for which convicted, } \\
\text { - date and place of conviction of any registrant, } \\
\text { - hair, eye color, } \\
\text { - height, } \\
\text { - race, } \\
\text { - sex and } \\
\text { - date of birth of } \\
\text { - any registrant, and any other information deemed necessary for the protection of the public. } \\
\text { Additionally, the department may utilize an internet web site or other electronic means to release the information. }\end{array}$ \\
\hline $\begin{array}{l}\text { Limitations on Residency or } \\
\text { Employment } \\
\text { (Mississippi) }\end{array}$ & $\begin{array}{l}\text { MISS. CODE ANN. } \S \S 43-15-305 \& 43-15-307 \text { (West 2008) } \\
\text { Registered sex offenders are prohibited from owning, operating, working for, or volunteering at a child care service. } \\
\text { MISS. CODE ANN. } \S 45-33-25(4) \text { (West } 2008 \text { ). } \\
\text { As of July 1, West } 2008 \text {, sex offenders may not establish residence within } 1500 \text { feet of a public or nonpublic }\end{array}$ \\
\hline
\end{tabular}

** Denotes those states where sex offender registration is required for convictions under the staff sexual misconduct laws of the states. Staff and inmates could also be required to register as sex offenders if the offense were charged under other registrable offenses.

This publication is developed by the NIC/WCL Project on Addressing Prison Rape under NIC Cooperative Agreement 06S20GJJ1.

This is not to be posted or reproduced without permission from the authors.

American University, Washington College of Law

Current as of August 2009 


\section{Fifty State Survey of Adult Sex Offender Registration Requirements}

\section{NIC/WCL Project on Addressing Prison Rape}

\begin{tabular}{|c|c|}
\hline $\begin{array}{l}\text { Limitations on Residency or } \\
\text { Employment Cont'd } \\
\text { (Mississippi) }\end{array}$ & $\begin{array}{l}\text { elementary or secondary school or childcare facility. However, this restriction does not apply to persons living } \\
\text { within } 1500 \text { of a school or child care facility prior to July } 1 \text {, West } 2008 \text { or to minors or wards. }\end{array}$ \\
\hline $\begin{array}{l}\text { Duration of Registration } \\
\text { (Mississippi) }\end{array}$ & $\begin{array}{l}\text { MISS. CODE ANN. } § 45-33-47 \text { (West 2008) } \\
\text { (2)(a) } 10 \text { years for sex offenders not subject to lifetime registration. } \\
\text { (2)(b) Life for offenders convicted of: } \\
\text { - Rape; } \\
\text { - Rape and assault with intent to ravish; } \\
\text { - Sexual battery; } \\
\text { - Sexual exploitation of children; or } \\
\text { - Carnal knowledge of a stepchild, adopted child or child of cohabiting partner. } \\
\text { (2)(d) Life for: } \\
\text { - Offenders with two separate convictions for registrable offenses; } \\
\text { - Offenders deemed sexual predators or sexually violent predators; or } \\
\text { - Offenders twice adjudicated delinquent for rape or sexual battery. }\end{array}$ \\
\hline \multicolumn{2}{|r|}{ MISSOURI** } \\
\hline $\begin{array}{l}\text { Registrable Offenses } \\
\text { (Missouri) }\end{array}$ & 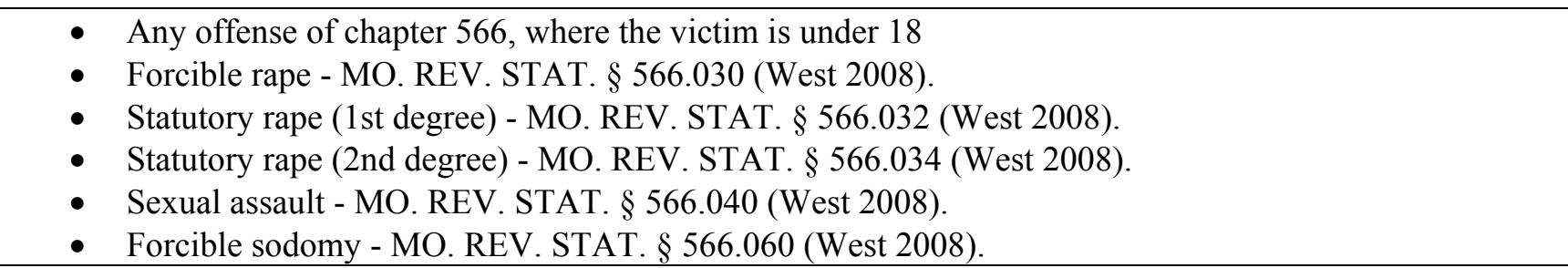 \\
\hline
\end{tabular}

** Denotes those states where sex offender registration is required for convictions under the staff sexual misconduct laws of the states. Staff and 118 inmates could also be required to register as sex offenders if the offense were charged under other registrable offenses.

This publication is developed by the NIC/WCL Project on Addressing Prison Rape under NIC Cooperative Agreement 06S20GJJ1.

This is not to be posted or reproduced without permission from the authors.

American University, Washington College of Law

Current as of August 2009 


\section{Fifty State Survey of Adult Sex Offender Registration Requirements}

\section{NIC/WCL Project on Addressing Prison Rape}

\begin{tabular}{|c|c|}
\hline $\begin{array}{l}\text { Registrable Offenses Cont'd } \\
\text { (Missouri) }\end{array}$ & 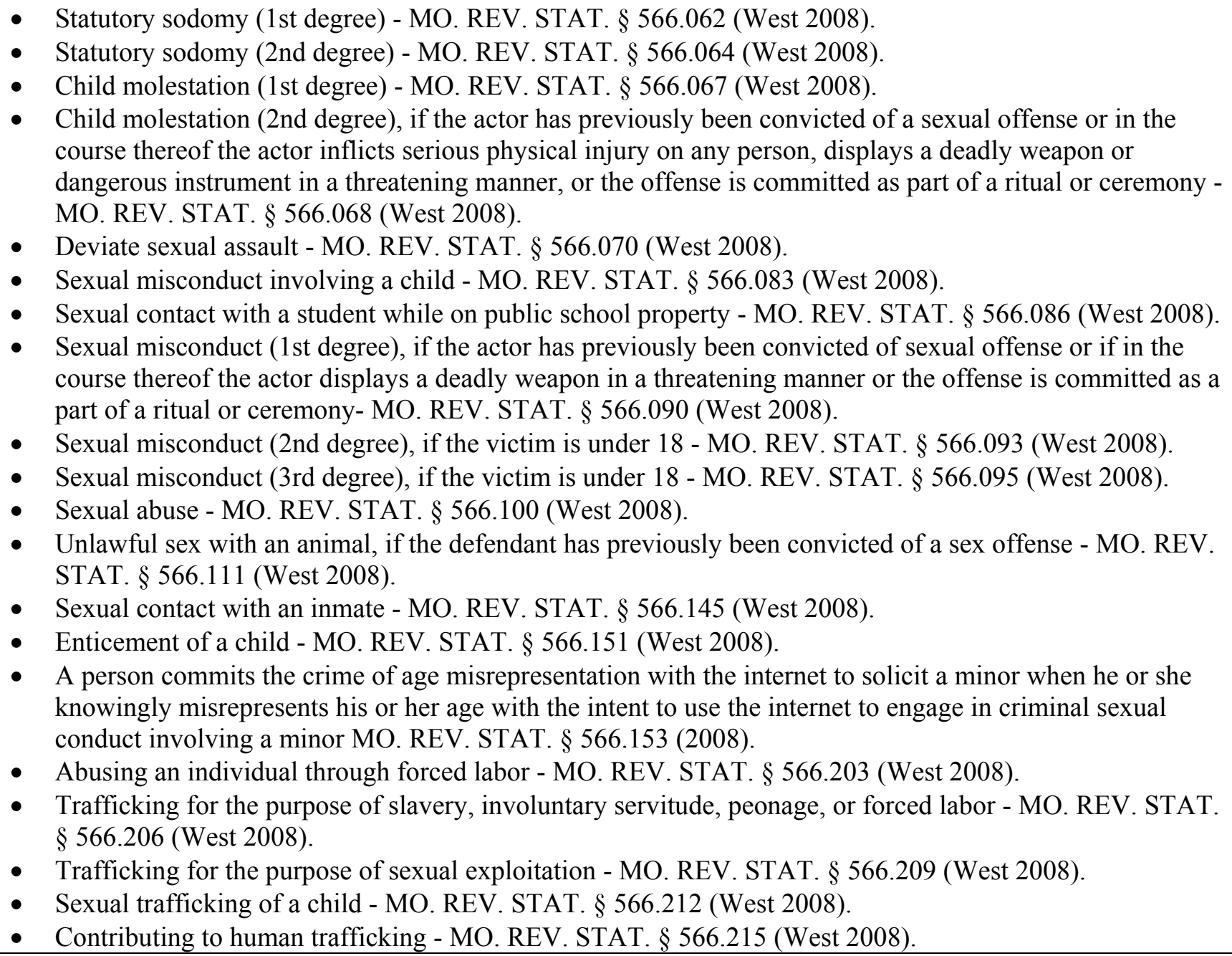 \\
\hline
\end{tabular}

** Denotes those states where sex offender registration is required for convictions under the staff sexual misconduct laws of the states. Staff and 119 inmates could also be required to register as sex offenders if the offense were charged under other registrable offenses.

This publication is developed by the NIC/WCL Project on Addressing Prison Rape under NIC Cooperative Agreement 06S20GJJ1.

This is not to be posted or reproduced without permission from the authors.

American University, Washington College of Law

Current as of August 2009 


\section{Fifty State Survey of Adult Sex Offender Registration Requirements}

\section{NIC/WCL Project on Addressing Prison Rape}

\begin{tabular}{|c|c|}
\hline $\begin{array}{l}\text { Registrable Offenses Cont'd } \\
\text { (Missouri) }\end{array}$ & 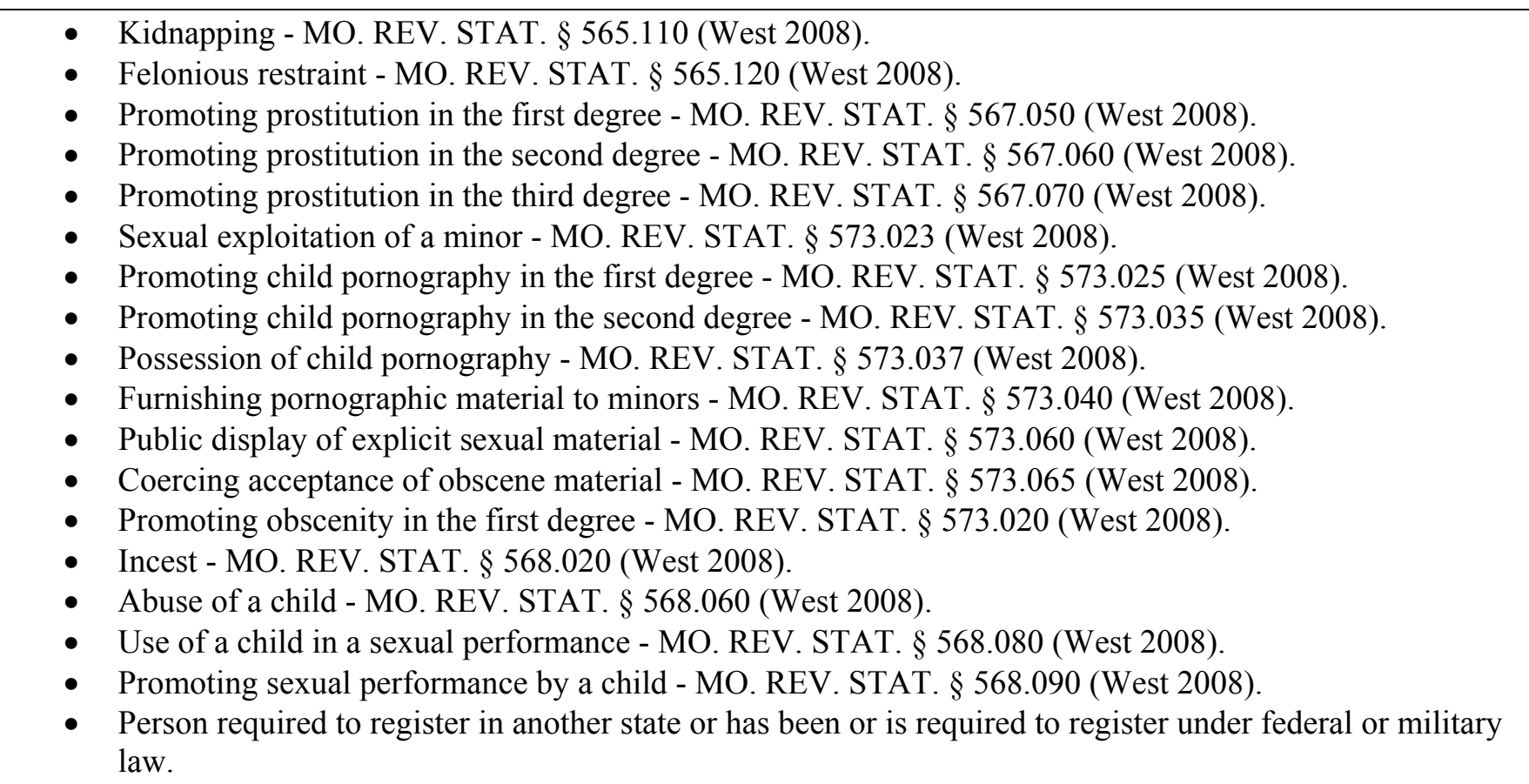 \\
\hline $\begin{array}{l}\text { Sex Offender Registration } \\
\text { Required for Staff Sexual } \\
\text { Misconduct? } \\
\text { (Missouri) }\end{array}$ & $\begin{array}{l}\text { YES } \\
\text { V.A.M.S. } \$ 566.145 \text { (West 2008) } \\
\text { 1. A person commits the crime of sexual contact with a prisoner or offender if: } \\
\text { (1) Such person is an employee of, or assigned to work in, any jail, prison or correctional facility and such } \\
\text { person has sexual intercourse or deviate sexual intercourse with a prisoner or offender; or }\end{array}$ \\
\hline
\end{tabular}

** Denotes those states where sex offender registration is required for convictions under the staff sexual misconduct laws of the states. Staff and 120 inmates could also be required to register as sex offenders if the offense were charged under other registrable offenses.

This publication is developed by the NIC/WCL Project on Addressing Prison Rape under NIC Cooperative Agreement 06S20GJJ1.

This is not to be posted or reproduced without permission from the authors.

American University, Washington College of Law

Current as of August 2009 


\section{Fifty State Survey of Adult Sex Offender Registration Requirements}

\section{NIC/WCL Project on Addressing Prison Rape}

\begin{tabular}{|c|c|}
\hline $\begin{array}{l}\text { Sex Offender Registration } \\
\text { Required for Staff Sexual } \\
\text { Misconduct? Cont'd } \\
\text { (Missouri) }\end{array}$ & $\begin{array}{l}\text { (2) Such person is a probation and parole officer and has sexual intercourse or deviate sexual intercourse } \\
\text { with an offender who is under the direct supervision of the officer. } \\
\text { 2. Sexual contact with an inmate is a class D felony. }\end{array}$ \\
\hline $\begin{array}{l}\text { Information Maintained in } \\
\text { Sex Offender Registry } \\
\text { (Missouri) }\end{array}$ & $\begin{array}{l}\text { V.A.M.S. } \$ 589.407 \\
\text { (1) A statement in writing signed by the person, giving the name, address, Social Security number and phone } \\
\text { number of the person, the license plate number and vehicle description, including the year, make, model, and color } \\
\text { of each vehicle owned or operated by the offender, any online identifiers, as defined in section } 43.651 \text {, RSMo, used } \\
\text { by the person, the place of employment of such person, enrollment within any institutions of higher education, the } \\
\text { crime which requires registration, whether the person was sentenced as a persistent or predatory offender pursuant } \\
\text { to section 558.018, RSMo, the date, place, and a brief description of such crime, the date and place of the } \\
\text { conviction or plea regarding such crime, the age and gender of the victim at the time of the offense and whether the } \\
\text { person successfully completed the Missouri sexual offender program pursuant to section } 589.040 \text {, if applicable; (2) } \\
\text { The fingerprints, palm prints, and a photograph of the person; and (3) A DNA sample, if a sample has not already } \\
\text { been obtained. } 2 \text {. The offender shall provide positive identification and documentation to substantiate the accuracy } \\
\text { of the information completed on the offender registration form, including but not limited to the following: (1) A } \\
\text { photocopy of a valid driver's license or nondriver's identification card; (2) A document verifying proof of the } \\
\text { offender's residency; and (3) A photocopy of the vehicle registration for each of the offender's vehicles. }\end{array}$ \\
\hline $\begin{array}{l}\text { Community Notification } \\
\text { and Websites } \\
\text { (Missouri) }\end{array}$ & $\begin{array}{l}\text { V.A.M.S. } \S 589.402 \\
\text { 1. The chief law enforcement officer of the county may maintain a web page on the Internet, which shall be open to } \\
\text { the public and shall include a registered sexual offender search capability. } \\
\text { V.A.M.S. } \S 589.403 \\
\text { When a person lists an address where he or she expects to reside that is not in this state, the initial registration shall }\end{array}$ \\
\hline
\end{tabular}

** Denotes those states where sex offender registration is required for convictions under the staff sexual misconduct laws of the states. Staff and inmates could also be required to register as sex offenders if the offense were charged under other registrable offenses.

This publication is developed by the NIC/WCL Project on Addressing Prison Rape under NIC Cooperative Agreement 06S20GJJ1.

This is not to be posted or reproduced without permission from the authors.

American University, Washington College of Law

Current as of August 2009 


\section{Fifty State Survey of Adult Sex Offender Registration Requirements}

\section{NIC/WCL Project on Addressing Prison Rape}

\begin{tabular}{|c|c|}
\hline $\begin{array}{l}\text { Community Notification } \\
\text { and Websites Cont'd } \\
\text { (Missouri) }\end{array}$ & $\begin{array}{l}\text { be forwarded to the Missouri state highway patrol. } \\
\text { V.A.M.S. } § 589.415 \\
\text { Any probation officer or parole officer assigned to a sexual offender who is required to register shall notify the } \\
\text { appropriate law enforcement officials whenever the officer has reason to beliece that the offender will be changing } \\
\text { his or her residence. }\end{array}$ \\
\hline $\begin{array}{l}\text { Limitations on Residency or } \\
\text { Employment } \\
\text { (Missouri) }\end{array}$ & 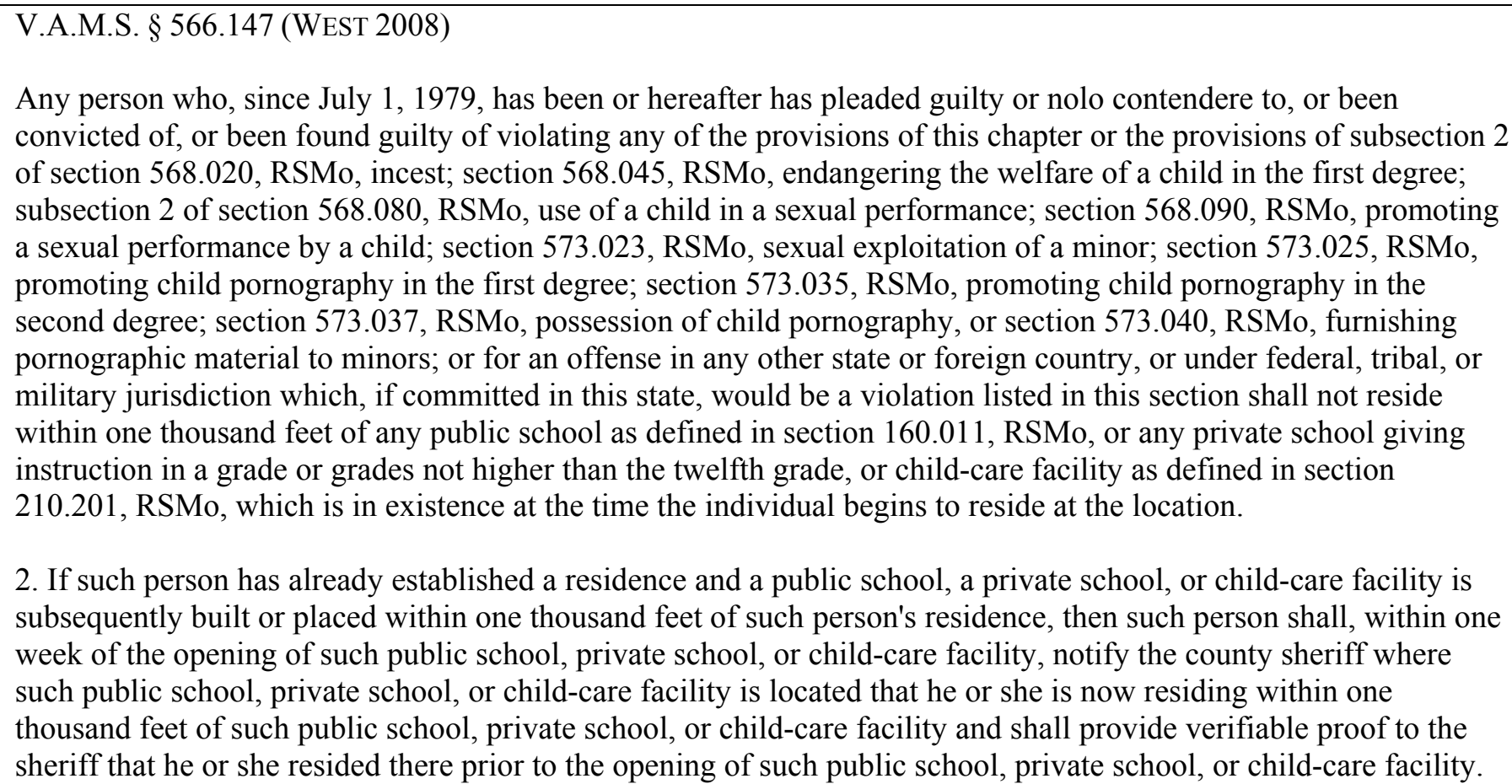 \\
\hline
\end{tabular}

** Denotes those states where sex offender registration is required for convictions under the staff sexual misconduct laws of the states. Staff and inmates could also be required to register as sex offenders if the offense were charged under other registrable offenses.

This publication is developed by the NIC/WCL Project on Addressing Prison Rape under NIC Cooperative Agreement 06S20GJJ1.

This is not to be posted or reproduced without permission from the authors.

American University, Washington College of Law

Current as of August 2009 


\section{Fifty State Survey of Adult Sex Offender Registration Requirements}

\section{NIC/WCL Project on Addressing Prison Rape}

\begin{tabular}{|c|c|}
\hline $\begin{array}{l}\text { Limitations on Residency or } \\
\text { Employment Cont'd } \\
\text { (Missouri) }\end{array}$ & 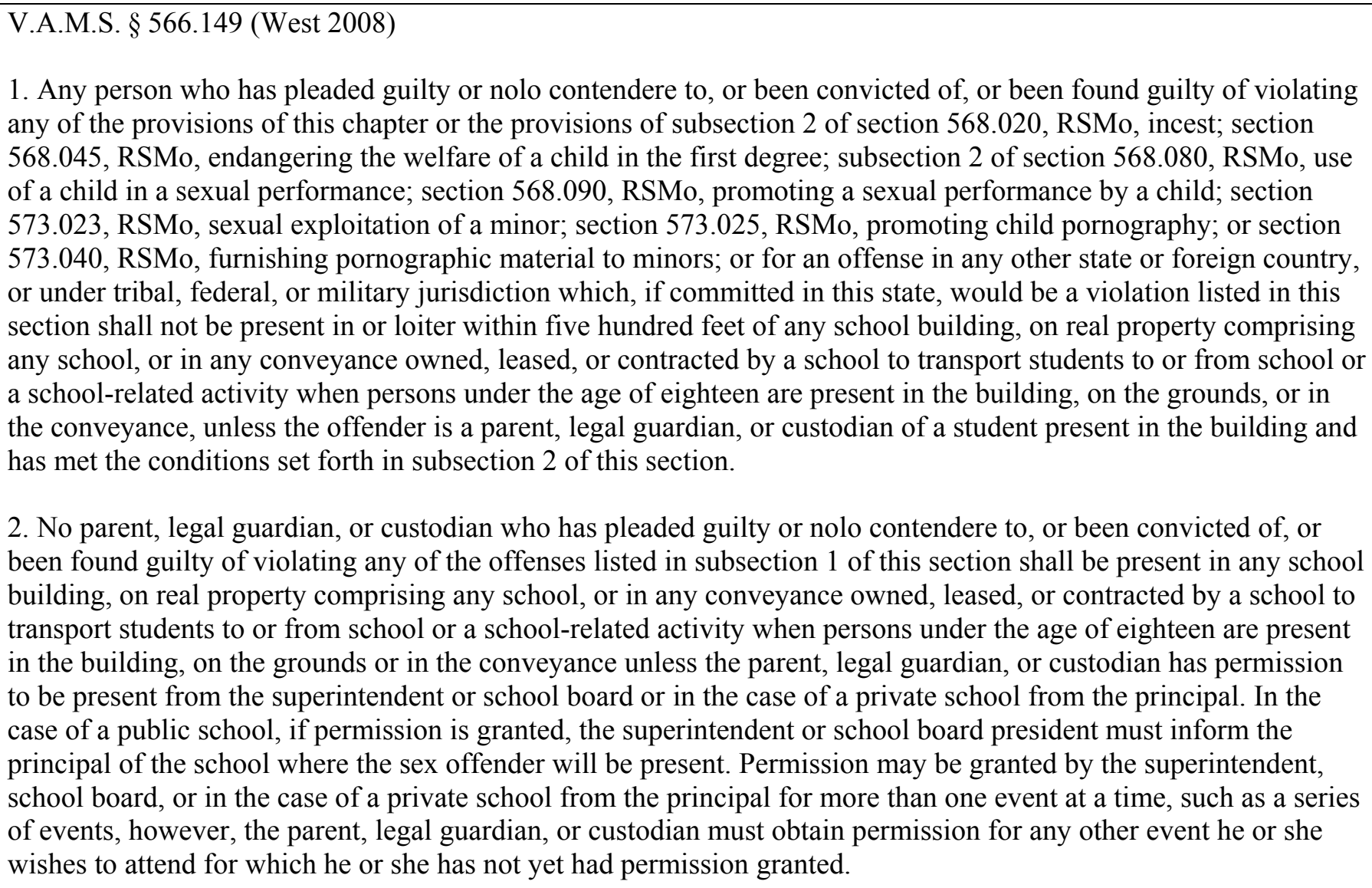 \\
\hline $\begin{array}{l}\text { Duration of Registration } \\
\text { (Missouri) }\end{array}$ & $\begin{array}{l}\text { V.A.M.S. } § 589.400 \\
\text { (3) Registration is a lifetime requirement unless the offender has been pardoned or the conviction has been }\end{array}$ \\
\hline
\end{tabular}

** Denotes those states where sex offender registration is required for convictions under the staff sexual misconduct laws of the states. Staff and inmates could also be required to register as sex offenders if the offense were charged under other registrable offenses.

This publication is developed by the NIC/WCL Project on Addressing Prison Rape under NIC Cooperative Agreement 06S20GJJ1.

This is not to be posted or reproduced without permission from the authors.

American University, Washington College of Law

Current as of August 2009 


\section{Fifty State Survey of Adult Sex Offender Registration Requirements}

\section{NIC/WCL Project on Addressing Prison Rape}

\begin{tabular}{|c|c|}
\hline $\begin{array}{l}\text { Duration of Registration } \\
\text { Cont'd } \\
\text { (Missouri) }\end{array}$ & reversed, vacated or set aside. \\
\hline & MONTANA $* *$ \\
\hline $\begin{array}{l}\text { Registrable Offenses } \\
\text { (Montana) }\end{array}$ & 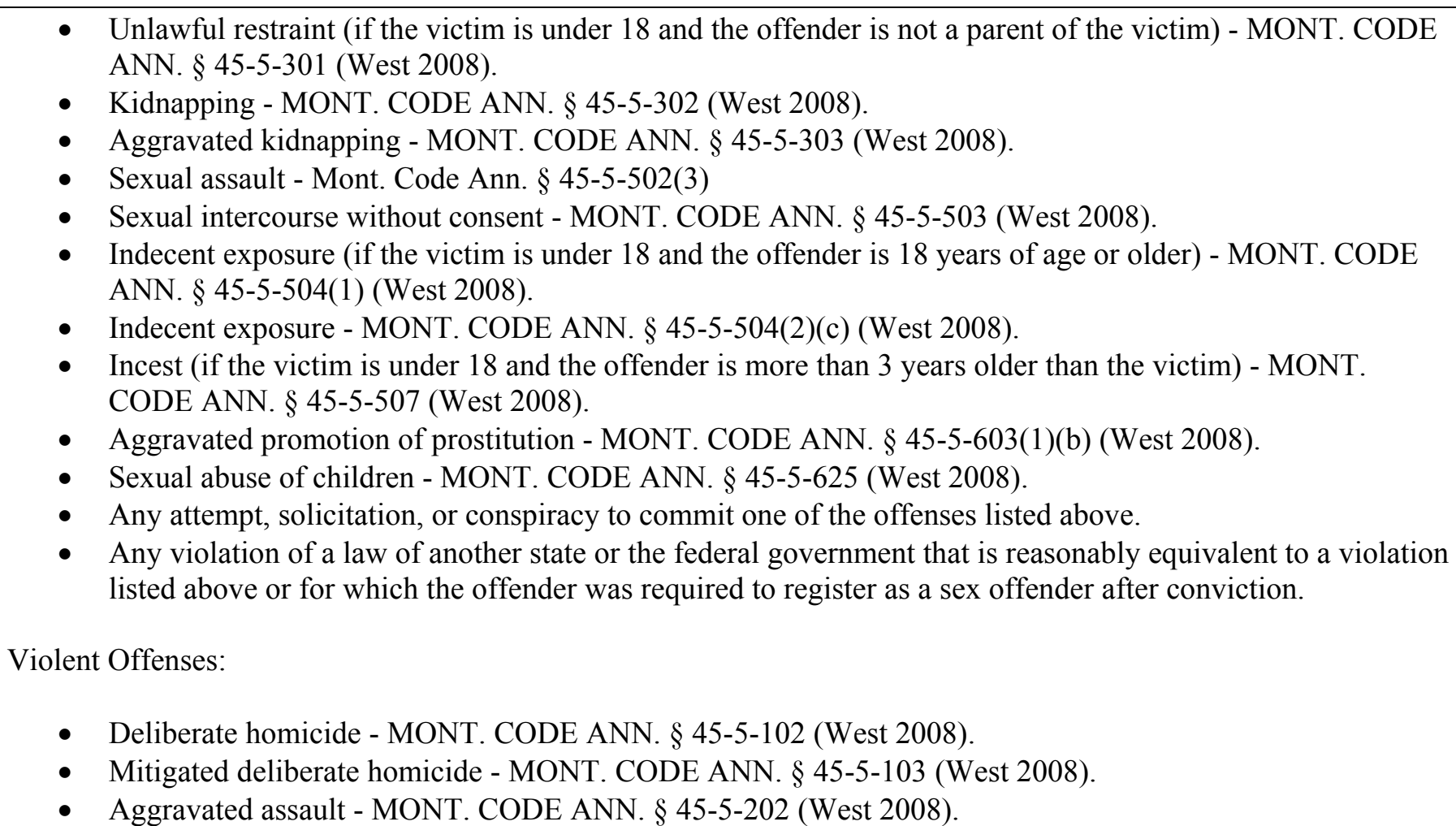 \\
\hline
\end{tabular}

** Denotes those states where sex offender registration is required for convictions under the staff sexual misconduct laws of the states. Staff and inmates could also be required to register as sex offenders if the offense were charged under other registrable offenses.

This publication is developed by the NIC/WCL Project on Addressing Prison Rape under NIC Cooperative Agreement 06S20GJJ1.

This is not to be posted or reproduced without permission from the authors.

American University, Washington College of Law

Current as of August 2009 


\section{Fifty State Survey of Adult Sex Offender Registration Requirements}

\section{NIC/WCL Project on Addressing Prison Rape}

\begin{tabular}{|c|c|}
\hline $\begin{array}{l}\text { Registrable Offenses Cont'd } \\
\text { (Montana) }\end{array}$ & 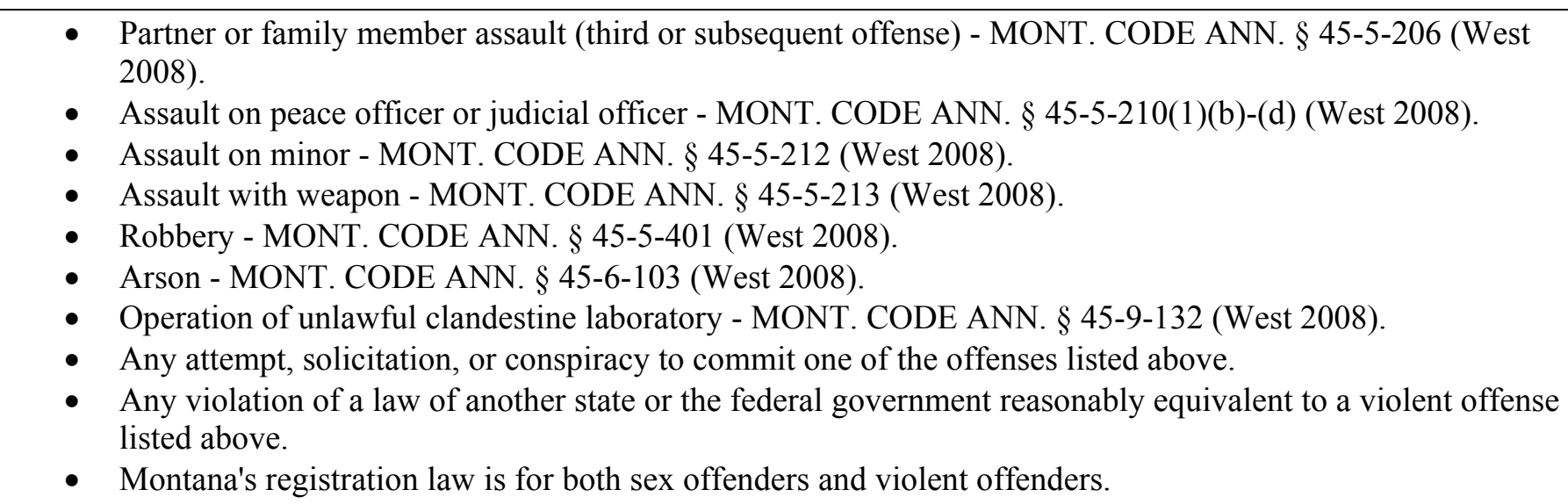 \\
\hline $\begin{array}{l}\text { Sex Offender Registration } \\
\text { Required for Staff Sexual } \\
\text { Misconduct? } \\
\text { (Montana) }\end{array}$ & $\begin{array}{l}\text { YES } \\
\text { MONT. CODE ANN. } \S 45-5-502 \text { (West 2008). } \\
\text { Sexual assault. } \\
\text { (1) A person who knowingly subjects another person to any sexual contact without consent commits the offense of } \\
\text { sexual assault. } \\
\text { (2) A person convicted of sexual assault shall be fined not to exceed } \$ 500 \text { or be imprisoned in the county jail for a } \\
\text { term not to exceed } 6 \text { months, or both. } \\
\text { (3) If the victim is less than } 16 \text { years old and the offender is } 3 \text { or more years older than the victim or if the offender } \\
\text { inflicts bodily injury upon anyone in the course of committing sexual assault, the offender shall be punished by life } \\
\text { imprisonment or by imprisonment in the state prison for a term of not less than } 4 \text { years, unless the judge makes a } \\
\text { written finding that there is good cause to impose a term of less than } 4 \text { years and imposes a term of less than } 4 \\
\text { years, or more than } 100 \text { years and may be fined not more than } \$ 50,000 \text {. }\end{array}$ \\
\hline
\end{tabular}

** Denotes those states where sex offender registration is required for convictions under the staff sexual misconduct laws of the states. Staff and inmates could also be required to register as sex offenders if the offense were charged under other registrable offenses.

This publication is developed by the NIC/WCL Project on Addressing Prison Rape under NIC Cooperative Agreement 06S20GJJ1.

This is not to be posted or reproduced without permission from the authors.

American University, Washington College of Law

Current as of August 2009 


\section{Fifty State Survey of Adult Sex Offender Registration Requirements}

\section{NIC/WCL Project on Addressing Prison Rape}

\begin{tabular}{|c|c|}
\hline $\begin{array}{l}\text { Sex Offender Registration } \\
\text { Required for Staff Sexual } \\
\text { Misconduct? Cont'd } \\
\text { (Montana) }\end{array}$ & $\begin{array}{l}\text { (4) An act "in the course of committing sexual assault" includes an attempt to commit the offense or flight after the } \\
\text { attempt or commission. } \\
\text { (5) (a) Subject to subsections (5)(b) and (5)(c), consent is ineffective under this section if the victim is: } \\
\text { (i) incarcerated in an adult or juvenile correctional, detention, or treatment facility or is on probation or } \\
\text { parole and the perpetrator is an employee, contractor, or volunteer of the supervising authority and has } \\
\text { supervisory or disciplinary authority over the victim, unless the act is part of a lawful search; } \\
\text { (ii) less than } 14 \text { years old and the offender is } 3 \text { or more years older than the victim; } \\
\text { (iii) receiving services from a youth care facility, as defined in } 52-2-602 \text {, and the perpetrator: } \\
\text { (A) has supervisory or disciplinary authority over the victim or is providing treatment to the victim; } \\
\text { and } \\
\text { (B) is an employee, contractor, or volunteer of the youth care facility; or } \\
\text { (iv) admitted to a mental health facility, as defined in } 53-21-102 \text {, is admitted to a community-based facility or a } \\
\text { residential facility, as those terms are defined in } 53-20-102 \text {, or is receiving community-based services, as defined in } \\
\text { 53-20-102, and the perpetrator: } \\
\text { (A) has supervisory or disciplinary authority over the victim or is providing treatment to the victim; and } \\
\text { (B) is an employee, contractor, or volunteer of the facility or community-based service. } \\
\text { MONT. CODE ANN. } \S 45-5-503 \text { (West } 2008) \text {. } \\
\text { Sexual intercourse without consent. } \\
\text { (1) A person who knowingly has sexual intercourse without consent with another person commits the offense of } \\
\text { sexual intercourse without consent. A person may not be convicted under this section based on the age of the } \\
\text { person's spouse, as provided in } 45-5-501(1)(\text { a)(ii)(D). } \\
\text { (2) A person convicted of sexual intercourse without consent shall be punished by life imprisonment or by } \\
\text { imprisonment in the state prison for a term of not less than } 2 \text { years or more than } 100 \text { years and may be fined not } \\
\text { more than } \$ 50,000 \text {, except as provided in } 46-18-219 \text {, } 46-18-222 \text {, and subsections ( } 3 \text { ) and (4) of this section. }\end{array}$ \\
\hline
\end{tabular}

** Denotes those states where sex offender registration is required for convictions under the staff sexual misconduct laws of the states. Staff and inmates could also be required to register as sex offenders if the offense were charged under other registrable offenses.

This publication is developed by the NIC/WCL Project on Addressing Prison Rape under NIC Cooperative Agreement 06S20GJJ1.

This is not to be posted or reproduced without permission from the authors.

American University, Washington College of Law

Current as of August 2009 


\section{Fifty State Survey of Adult Sex Offender Registration Requirements}

\section{NIC/WCL Project on Addressing Prison Rape}

\begin{tabular}{|c|c|}
\hline $\begin{array}{l}\text { Sex Offender Registration } \\
\text { Required for Staff Sexual } \\
\text { Misconduct? Cont'd } \\
\text { (Montana) }\end{array}$ & $\begin{array}{l}\text { (3) (a) If the victim is less than } 16 \text { years old and the offender is } 4 \text { or more years older than the victim or if the } \\
\text { offender inflicts bodily injury upon anyone in the course of committing sexual intercourse without consent, the } \\
\text { offender shall be punished by life imprisonment or by imprisonment in the state prison for a term of not less than } 4 \\
\text { years or more than } 100 \text { years and may be fined not more than } \$ 50,000 \text {, except as provided in } 46-18-219 \text { and } 46-18 \text { - } \\
222 \text {. }\end{array}$ \\
\hline $\begin{array}{l}\text { Information Maintained in } \\
\text { Sex Offender Registry } \\
\text { (Montana) }\end{array}$ & $\begin{array}{l}\text { M.C.A. § 46-23-503 (WEST 2008) } \\
\text { (1) A sexual or violent offender who is released from the custody of the department of corrections must be informed } \\
\text { in writing not less than } 10 \text { days prior to release of the duty to register under this part by the official in charge of the } \\
\text { place of confinement. } \\
\text { (2) Prior to the offender's release from custody, the official shall obtain and give to the department of justice and to } \\
\text { the sheriff of the county in which the offender intends to reside or, if the offender intends to reside in a } \\
\text { municipality, to the chief of police of the municipality: } \\
\text { (a) the address at which the offender intends to reside upon release from the department's custody; } \\
\text { (b) the offender's fingerprints and photo, unless they are already in the possession of the department of justice, } \\
\text { sheriff, or chief of police; and } \\
\text { (c) a form signed by and read to or by the offender stating that the offender's duty to register under this part has } \\
\text { been explained to the offender. }\end{array}$ \\
\hline $\begin{array}{l}\text { Community Notification } \\
\text { and Websites } \\
\text { (Montana) }\end{array}$ & $\begin{array}{l}\text { M.C.A. } \S 46-23-508 \text { (WEST 2008) } \\
\text { (b) A law enforcement agency shall release any offender registration information relevant to the public if the } \\
\text { agency determines that a registered offender is a risk to the safety of the community and that disclosure of the } \\
\text { registration information may protect the public and, at a minimum: } \\
\text { (i) If an offender was given a level } 1 \text { designation the agency with which the offender is registered shall notify } \\
\text { the agency in whose jurisdiction the offense occurred of the registration; }\end{array}$ \\
\hline
\end{tabular}

** Denotes those states where sex offender registration is required for convictions under the staff sexual misconduct laws of the states. Staff and inmates could also be required to register as sex offenders if the offense were charged under other registrable offenses.

This publication is developed by the NIC/WCL Project on Addressing Prison Rape under NIC Cooperative Agreement 06S20GJJ1.

This is not to be posted or reproduced without permission from the authors.

American University, Washington College of Law

Current as of August 2009 


\section{Fifty State Survey of Adult Sex Offender Registration Requirements}

\section{NIC/WCL Project on Addressing Prison Rape}

\begin{tabular}{|c|c|}
\hline $\begin{array}{l}\text { Community Notification } \\
\text { and Websites Cont'd } \\
\text { (Montana) }\end{array}$ & $\begin{array}{l}\text { (ii) If an offender was given a level } 2 \text { designation, the agency with which the offender is registered may } \\
\text { disseminate the offender's name to the public with the notation that the offender is a sexual or violent offender } \\
\text { and may notify a victim of the offense and any agency, organization, or group serving persons who have } \\
\text { characteristics similar to those of a previous victim } \\
\text { (iii) If an offender was given a level } 3 \text { designation, the agency shall give the victim and the public } \\
\text { notification. } \\
\text { - The agency shall also include the date of the offender's release from confinement or if not confined, the date the } \\
\text { offender was sentenced, with a notation that the offender was not confined, and shall include the community in } \\
\text { which the offense occurred. } \\
\text { (3) A state or local law enforcement agency may use the internet to disseminate the information allowed by this } \\
\text { section to the public. }\end{array}$ \\
\hline $\begin{array}{l}\text { Limitations on Residency or } \\
\text { Employment } \\
\text { (Montana) }\end{array}$ & $\begin{array}{l}\text { M.C.A. } \$ 46-18-255 \text { (WEST 2008) } \\
\text { (1) The sentencing judge may impose reasonable employment restrictions upon sexual or violent offenders to } \\
\text { protect persons likely to be victims of further offenses by the offender. } \\
\text { (2) Persons convicted of sexual offenses involving a minor who have been designated as a level } 3 \text { offender are } \\
\text { restricted from living in the proximity of a preschool, elementary or high school, licensed day-care center, church or } \\
\text { park maintained by a city, town, or county. }\end{array}$ \\
\hline $\begin{array}{l}\text { Duration of Registration } \\
\text { (Montana) }\end{array}$ & $\begin{array}{l}\text { M.C.A. } \$ 46-23-506 \text { (WEST 2008) } \\
\text { (2)(a) } 10 \text { years for violent offenders. } \\
\text { (2)(b) Life for: } \\
\text { - Sexual offenders } \\
\text { - Violent offenders that have been convicted of failing to keep registration current during the 10-year registration } \\
\text { period. }\end{array}$ \\
\hline
\end{tabular}

** Denotes those states where sex offender registration is required for convictions under the staff sexual misconduct laws of the states. Staff and 128 inmates could also be required to register as sex offenders if the offense were charged under other registrable offenses.

This publication is developed by the NIC/WCL Project on Addressing Prison Rape under NIC Cooperative Agreement 06S20GJJ1.

This is not to be posted or reproduced without permission from the authors.

American University, Washington College of Law

Current as of August 2009 


\section{Fifty State Survey of Adult Sex Offender Registration Requirements}

\section{NIC/WCL Project on Addressing Prison Rape}

\begin{tabular}{|c|c|}
\hline & NEBRASKA \\
\hline $\begin{array}{l}\text { Registrable Offenses } \\
\text { (Nebraska) }\end{array}$ & 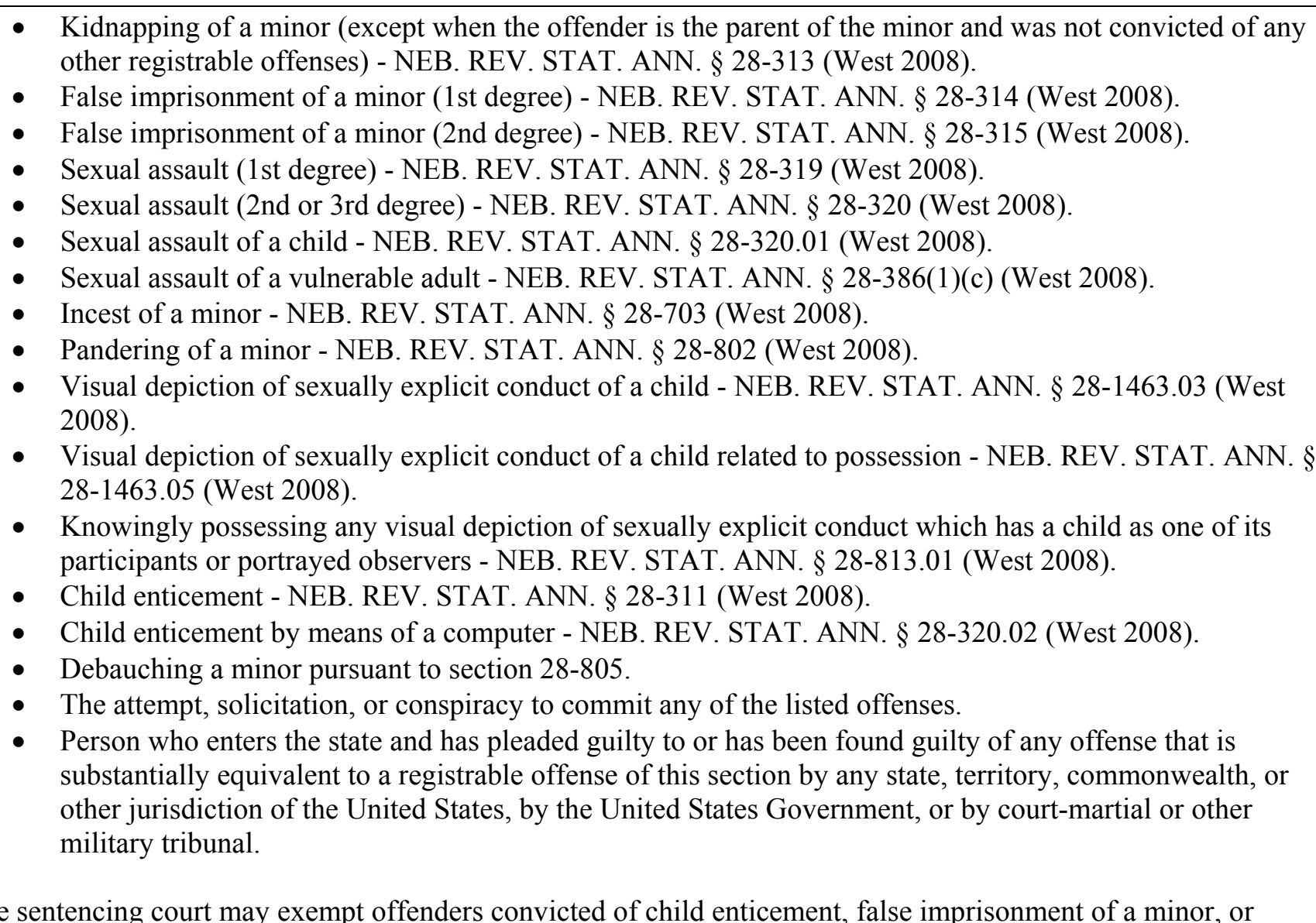 \\
\hline
\end{tabular}

** Denotes those states where sex offender registration is required for convictions under the staff sexual misconduct laws of the states. Staff and 129 inmates could also be required to register as sex offenders if the offense were charged under other registrable offenses.

This publication is developed by the NIC/WCL Project on Addressing Prison Rape under NIC Cooperative Agreement 06S20GJJ1.

This is not to be posted or reproduced without permission from the authors.

American University, Washington College of Law

Current as of August 2009 


\section{Fifty State Survey of Adult Sex Offender Registration Requirements}

\section{NIC/WCL Project on Addressing Prison Rape}

\begin{tabular}{|c|c|}
\hline $\begin{array}{l}\text { Registrable Offenses Cont'd } \\
\text { (Nebraska) }\end{array}$ & kidnapping. \\
\hline $\begin{array}{l}\text { Sex Offender Registration } \\
\text { Required for Staff Sexual } \\
\text { Misconduct? } \\
\text { (Nebraska) }\end{array}$ & NO \\
\hline $\begin{array}{l}\text { Information Maintained in } \\
\text { Sex Offender Registry } \\
\text { (Nebraska) }\end{array}$ & $\begin{array}{l}\text { NEB. REV. ST. § 29-4006 (WEST 2008) } \\
\text { (1) (a) The legal name and all aliases which the person has used or under which the person has been known; } \\
\text { (b) A complete description of the person, including date of birth, social security number, photographs, and } \\
\text { fingerprints; } \\
\text { (c) A listing of each registrable offense under section } 29-4003 \text { to which the person pleaded guilty or was } \\
\text { found guilty, the jurisdiction where each offense was committed, the court in which the person pleaded } \\
\text { guilty or was found guilty of each offense, and the name under which the person pleaded guilty or was } \\
\text { found guilty of each offense; } \\
\text { (d) The name and location of each jail, penal or correctional facility, or public or private institution to which } \\
\text { the person was incarcerated for each offense and the actual time served or confined; and } \\
\text { (e) The address of the person's current residence and place of employment or vocation and any school he or } \\
\text { she is attending. }\end{array}$ \\
\hline $\begin{array}{l}\text { Community Notification } \\
\text { and Websites } \\
\text { (Nebraska) }\end{array}$ & $\begin{array}{l}\text { NEB. REV. ST. § 29-4013 (WEST 2008) } \\
\text { (c) The procedures for release of information established by the Nebraska State Patrol shall provide for three levels }\end{array}$ \\
\hline
\end{tabular}

** Denotes those states where sex offender registration is required for convictions under the staff sexual misconduct laws of the states. Staff and 130 inmates could also be required to register as sex offenders if the offense were charged under other registrable offenses.

This publication is developed by the NIC/WCL Project on Addressing Prison Rape under NIC Cooperative Agreement 06S20GJJ1.

This is not to be posted or reproduced without permission from the authors.

American University, Washington College of Law

Current as of August 2009 


\section{Fifty State Survey of Adult Sex Offender Registration Requirements}

\section{NIC/WCL Project on Addressing Prison Rape}

\begin{tabular}{|c|c|}
\hline $\begin{array}{l}\text { Community Notification } \\
\text { and Websites Cont'd } \\
(\text { Nebraska) }\end{array}$ & $\begin{array}{l}\text { of notification by the law enforcement agency in whose jurisdiction the sex offender is to be released depending on } \\
\text { the risk of recidivism by the sex offender as follows: } \\
\text { (i) If the risk of recidivism is low, other law enforcement agencies shall be notified; } \\
\text { (ii) If the risk of recidivism is moderate, in addition to the notice required by subdivision (i) of this subdivision, } \\
\text { schools, day care centers, health care facilities providing services to children or vulnerable adults, and religious } \\
\text { and youth organizations shall be notified; and } \\
\text { (iii) If the risk of recidivism is high, in addition to the notice required by subdivisions (i) and (ii) of this } \\
\text { subdivision, the public shall be notified through means designed to reach members of the public, which are } \\
\text { limited to } \\
\text { o direct contact, } \\
\text { O news releases, } \\
\text { O a method utilizing a telephone system, or } \\
\text { o the Internet. } \\
\text { - The Nebraska State Patrol shall provide notice of sex offenders with a high risk of recidivism to at least one legal } \\
\text { newspaper published in and of general circulation in the county where the offender is registered or, if NO is } \\
\text { published in the county, in a legal newspaper of general circulation in such county. } \\
\text { - If any means of notification proposes a fee for usage, then nonprofit organizations holding a certificate of } \\
\text { exemption under section } 501 \text { (c) of the Internal Revenue Code shall not be charged. }\end{array}$ \\
\hline $\begin{array}{l}\text { Limitations on Residency or } \\
\text { Employment } \\
\text { (Nebraska) }\end{array}$ & (2: \\
\hline $\begin{array}{l}\text { Duration of Registration } \\
\text { (Nebraska) }\end{array}$ & $\begin{array}{l}\text { NEB. REV. ST. } § 29-4005 \text { (WEST 2008). } \\
10 \text { years for persons not subject to lifetime registration. } \\
\text { Life for persons: } \\
\text { - Convicted of an aggravated sex offense; }\end{array}$ \\
\hline
\end{tabular}

** Denotes those states where sex offender registration is required for convictions under the staff sexual misconduct laws of the states. Staff and 131 inmates could also be required to register as sex offenders if the offense were charged under other registrable offenses.

This publication is developed by the NIC/WCL Project on Addressing Prison Rape under NIC Cooperative Agreement 06S20GJJ1.

This is not to be posted or reproduced without permission from the authors.

American University, Washington College of Law

Current as of August 2009 


\section{Fifty State Survey of Adult Sex Offender Registration Requirements}

\section{NIC/WCL Project on Addressing Prison Rape}

\begin{tabular}{|c|c|}
\hline $\begin{array}{l}\text { Duration of Registration } \\
\text { Cont'd } \\
(\text { Nebraska) }\end{array}$ & $\begin{array}{l}\text { - With prior convictions for a registrable offense; or } \\
\text { - Deemed sexually violent predators }\end{array}$ \\
\hline & NEVADA \\
\hline $\begin{array}{l}\text { Registrable Offenses } \\
\text { (Nevada) }\end{array}$ & 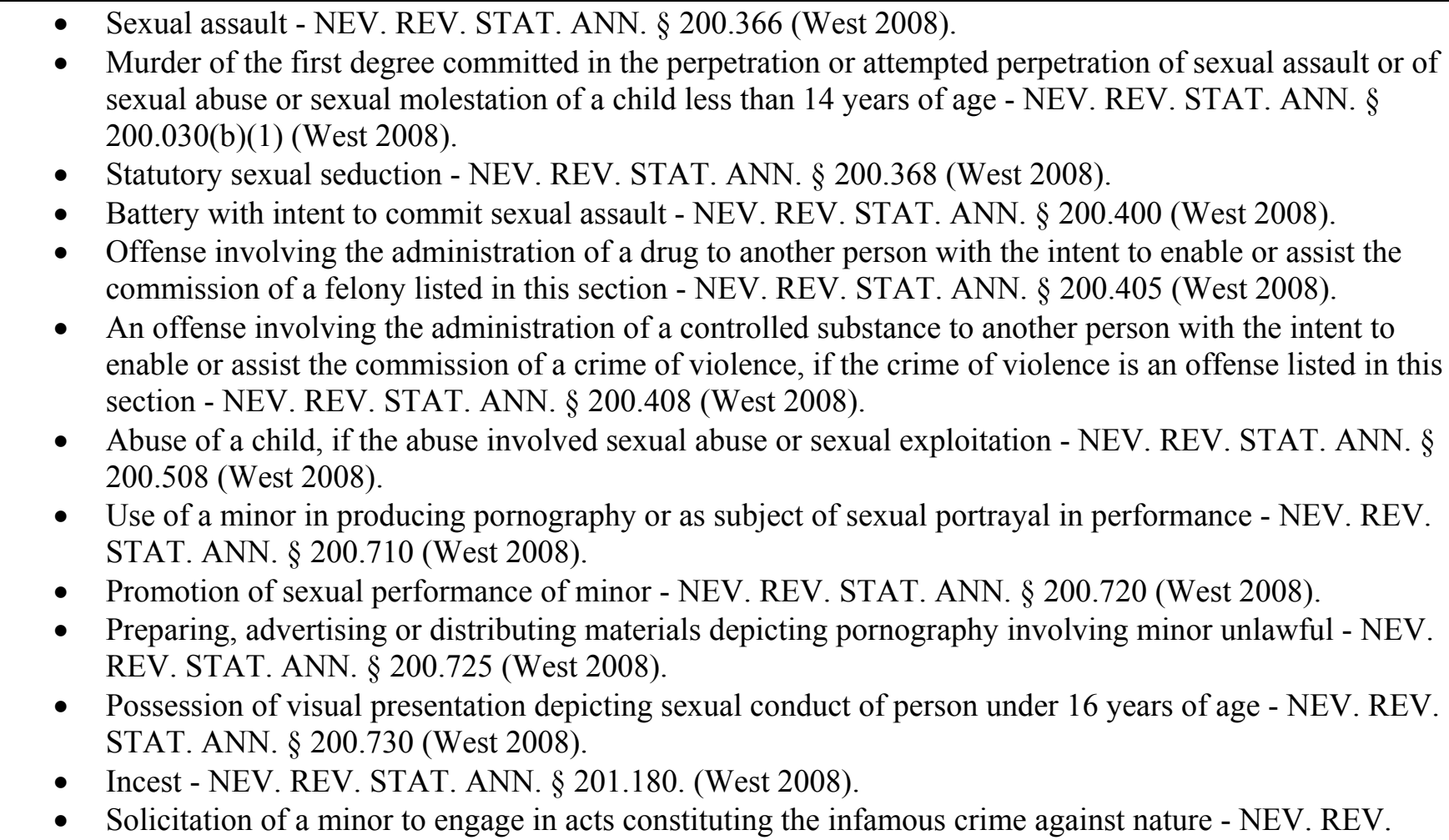 \\
\hline
\end{tabular}

** Denotes those states where sex offender registration is required for convictions under the staff sexual misconduct laws of the states. Staff and 132 inmates could also be required to register as sex offenders if the offense were charged under other registrable offenses.

This publication is developed by the NIC/WCL Project on Addressing Prison Rape under NIC Cooperative Agreement 06S20GJJ1.

This is not to be posted or reproduced without permission from the authors.

American University, Washington College of Law

Current as of August 2009 


\section{Fifty State Survey of Adult Sex Offender Registration Requirements}

\section{NIC/WCL Project on Addressing Prison Rape}

\begin{tabular}{|c|c|}
\hline $\begin{array}{l}\text { Registrable Offenses Cont'd } \\
\text { (Nevada) }\end{array}$ & 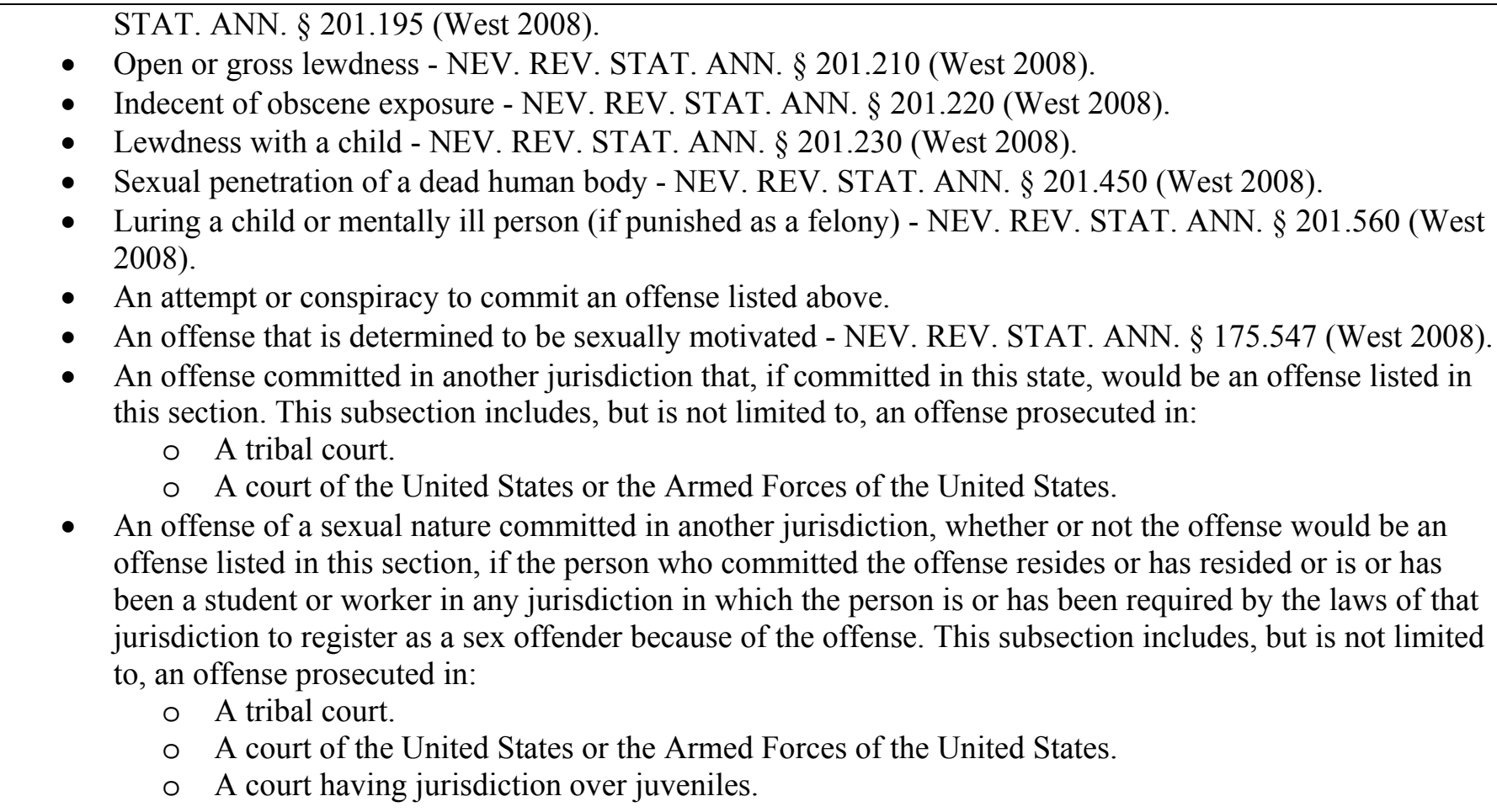 \\
\hline $\begin{array}{l}\text { Sex Offender Registration } \\
\text { Required for Staff Sexual } \\
\text { Misconduct? } \\
(\text { Nevada) }\end{array}$ & NO \\
\hline
\end{tabular}

** Denotes those states where sex offender registration is required for convictions under the staff sexual misconduct laws of the states. Staff and inmates could also be required to register as sex offenders if the offense were charged under other registrable offenses.

This publication is developed by the NIC/WCL Project on Addressing Prison Rape under NIC Cooperative Agreement 06S20GJJ1.

This is not to be posted or reproduced without permission from the authors.

American University, Washington College of Law

Current as of August 2009 


\section{Fifty State Survey of Adult Sex Offender Registration Requirements}

\section{NIC/WCL Project on Addressing Prison Rape}

\begin{tabular}{|c|c|}
\hline $\begin{array}{l}\text { Information Maintained in } \\
\text { Sex Offender Registry } \\
\text { (Nevada) }\end{array}$ & $\begin{array}{l}\text { N.R.S. } § 179 D .460 \text { (West 2008) } \\
\text { - name } \\
\text { - all aliases } \\
\text { - complete physical description } \\
\text { - photograph } \\
\text { - fingerprints } \\
\text { - date of birth } \\
\text { - social security number } \\
\text { - ID number from driver's license or state-issued ID card } \\
\text { - address } \\
\text { - length of time at current address } \\
\text { - address of any other place where offender expects to reside in the future } \\
\text { - length of time offender expects to remain in the county where he/she resides } \\
\text { - name, address and type of business of all current and expected future employers } \\
\text { - name, address and type of activity associated with any volunteer work of the offender } \\
\text { - name, address and type of educational institution or school that the offenders attends or is employed by. } \\
\text { - license number and description of all vehicles registered to or frequently driven by the offender } \\
\text { - level of community notification assigned } \\
\text { - court in which convicted } \\
\text { - name under which convicted } \\
\text { - name and location of each penal institution, school, hospital or mental facility to which he was committed } \\
\text { - location where offense was committed } \\
\text { - age, gender, race and description of the victim } \\
\text { - method of operation used to commit the offense, including method of obtaining access to the victim, injuries } \\
\text { inflicted, instruments or weapons used, property taken or other distinctive characteristics. } \\
\text { N.R.S. § } 176.0913 \text { (West } 2008 \text { ) }\end{array}$ \\
\hline
\end{tabular}

** Denotes those states where sex offender registration is required for convictions under the staff sexual misconduct laws of the states. Staff and 134 inmates could also be required to register as sex offenders if the offense were charged under other registrable offenses.

This publication is developed by the NIC/WCL Project on Addressing Prison Rape under NIC Cooperative Agreement 06S20GJJ1.

This is not to be posted or reproduced without permission from the authors.

American University, Washington College of Law

Current as of August 2009 


\section{Fifty State Survey of Adult Sex Offender Registration Requirements}

\section{NIC/WCL Project on Addressing Prison Rape}

\begin{tabular}{|c|c|}
\hline $\begin{array}{l}\text { Information Maintained in } \\
\text { Sex Offender Registry } \\
\text { Cont'd } \\
\text { (Nevada) }\end{array}$ & $\begin{array}{l}\text { 1. If a defendant is convicted of an offense listed in subsection } 4 \text {, the court, at sentencing, shall order that: (a) The } \\
\text { name, social security number, date of birth and any other information identifying the defendant be submitted to the } \\
\text { Central Repository for Nevada Records of Criminal History; and } \quad \text { (b) A biological specimen be obtained from the } \\
\text { defendant pursuant to the provisions of this section and that the specimen be used for an analysis to determine the } \\
\text { genetic markers of the specimen. }\end{array}$ \\
\hline $\begin{array}{l}\text { Community Notification } \\
\text { and Websites } \\
\text { (Nevada) }\end{array}$ & $\begin{array}{l}\text { N.R.S. } \S 179 \text { D. } 730 \text { (West 2008) } \\
\text { 1. Except as otherwise provided in this section, the guidelines and procedures for community notification } \\
\text { established by the attorney general must provide for the following levels of notification, depending upon the risk of } \\
\text { recidivism of the sex offender: } \\
\text { (a) If the risk of recidivism is low, the sex offender must be assigned a Tier } 1 \text { level of notification, and the law } \\
\text { enforcement agency in whose jurisdiction the sex offender resides or is a student or worker shall notify other law } \\
\text { enforcement agencies that are likely to encounter the sex offender. } \\
\text { (b) If the risk of recidivism is moderate, the sex offender must be assigned a Tier } 2 \text { level of notification, and the } \\
\text { law enforcement agency in whose jurisdiction the sex offender resides or is a student or worker shall provide } \\
\text { notification pursuant to paragraph (a) and shall notify schools and religious and youth organizations that are } \\
\text { likely to encounter the sex offender. } \\
\text { (c) If the risk of recidivism is high, the sex offender must be assigned a Tier } 3 \text { level of notification, and the law } \\
\text { enforcement agency in whose jurisdiction the sex offender resides or is a student or worker shall provide } \\
\text { notification pursuant to paragraphs (a) and (b) and shall notify the public through means designed to reach } \\
\text { members of the public who are likely to encounter the sex offender. } \\
\text { 2. If the sex offender is assigned a Tier } 2 \text { or Tier } 3 \text { level of notification and the sex offender has committed a sexual } \\
\text { offense against a person less than } 18 \text { years of age, the law enforcement agency in whose jurisdiction the sex } \\
\text { offender resides or is a student or worker shall provide the appropriate notification for Tier } 2 \text { or Tier } 3 \text { and, in } \\
\text { addition, shall notify: } \\
\text { (a) Motion picture theaters, other than adult motion picture theaters, which are likely to encounter the sex } \\
\text { offender; and } \\
\text { (b) Businesses which are likely to encounter the sex offender and which primarily have children as customers }\end{array}$ \\
\hline
\end{tabular}

** Denotes those states where sex offender registration is required for convictions under the staff sexual misconduct laws of the states. Staff and inmates could also be required to register as sex offenders if the offense were charged under other registrable offenses.

This publication is developed by the NIC/WCL Project on Addressing Prison Rape under NIC Cooperative Agreement 06S20GJJ1.

This is not to be posted or reproduced without permission from the authors.

American University, Washington College of Law

Current as of August 2009 


\section{Fifty State Survey of Adult Sex Offender Registration Requirements}

\section{NIC/WCL Project on Addressing Prison Rape}

\begin{tabular}{|c|c|}
\hline $\begin{array}{l}\text { Community Notification } \\
\text { and Websites Cont'd } \\
\text { (Nevada) }\end{array}$ & $\begin{array}{l}\text { or conduct events that primarily children attend. Notification pursuant to this subsection must include a copy } \\
\text { of a photograph of the sex offender. } \\
\text { 3. If the sex offender has been declared to be a sexually violent predator, the sex offender must be assigned a Tier } 3 \\
\text { level of notification. }\end{array}$ \\
\hline $\begin{array}{l}\text { Limitations on Residency or } \\
\text { Employment } \\
\text { (Nevada) }\end{array}$ & None. \\
\hline $\begin{array}{l}\text { Duration of Registration } \\
\text { (Nevada) }\end{array}$ & $\begin{array}{l}\text { N.R.S. } \S 179 \text { D. } 270 \text { (West } 2008 \text { ) } \\
\text { Sex offenders must register for as long as he/she resides, works or attends school in Nevada. } \\
\text { Offenders may petition to terminate registration if } 15 \text { consecutive years have elapsed without a subsequent } \\
\text { conviction and the offender has been in compliance with his/her registration requirements. } \\
\text { Offenders may not petition for termination of the registration requirements if they: } \\
\text { - Are subject to community notification or lifetime supervisions pursuant to Nevada Revised Statute } \S 176.0931 \\
\text { (West } 2008 \text { ); } \\
\text { - Have been declared a sexually violent predator; } \\
\text { - Have been convicted of: } \\
\text { o } 1 \text { or more sexually violent offenses; } \\
\text { o } 2 \text { or more sexual offenses; } \\
\text { o } 2 \text { or more crimes against a child; or } \\
\text { o } 1 \text { or more sexual offenses and } 1 \text { or more crimes against a child. }\end{array}$ \\
\hline
\end{tabular}

** Denotes those states where sex offender registration is required for convictions under the staff sexual misconduct laws of the states. Staff and 136 inmates could also be required to register as sex offenders if the offense were charged under other registrable offenses.

This publication is developed by the NIC/WCL Project on Addressing Prison Rape under NIC Cooperative Agreement 06S20GJJ1.

This is not to be posted or reproduced without permission from the authors.

American University, Washington College of Law

Current as of August 2009 


\section{Fifty State Survey of Adult Sex Offender Registration Requirements}

\section{NIC/WCL Project on Addressing Prison Rape}

\begin{tabular}{|c|c|}
\hline $\begin{array}{l}\text { Registrable Offenses } \\
\text { (New Hampshire) }\end{array}$ & 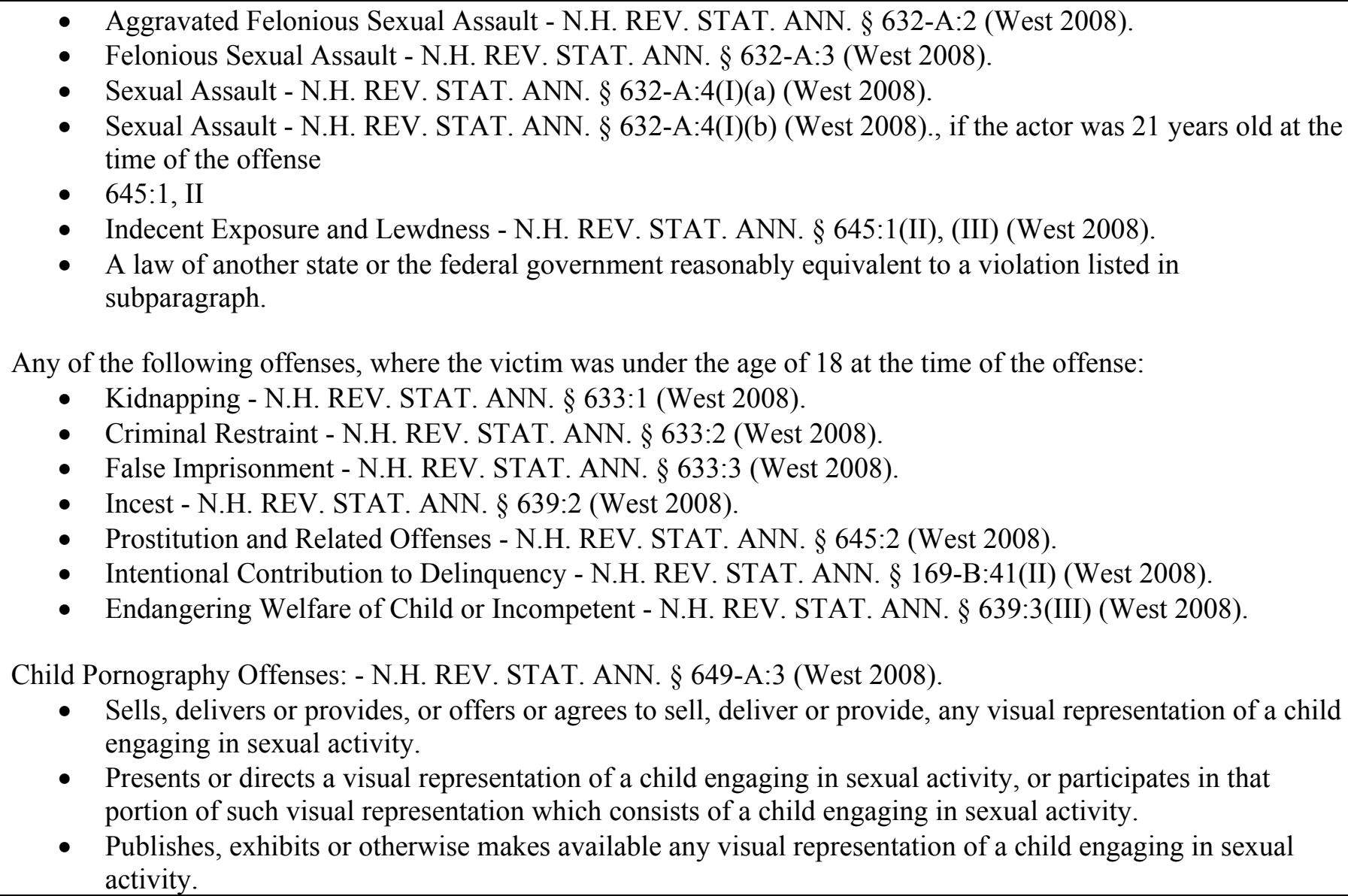 \\
\hline
\end{tabular}

** Denotes those states where sex offender registration is required for convictions under the staff sexual misconduct laws of the states. Staff and 137 inmates could also be required to register as sex offenders if the offense were charged under other registrable offenses.

This publication is developed by the NIC/WCL Project on Addressing Prison Rape under NIC Cooperative Agreement 06S20GJJ1.

This is not to be posted or reproduced without permission from the authors.

American University, Washington College of Law

Current as of August 2009 


\section{Fifty State Survey of Adult Sex Offender Registration Requirements}

\section{NIC/WCL Project on Addressing Prison Rape}

\begin{tabular}{|c|c|}
\hline $\begin{array}{l}\text { Registrable Offenses Cont'd } \\
\text { (New Hampshire) }\end{array}$ & 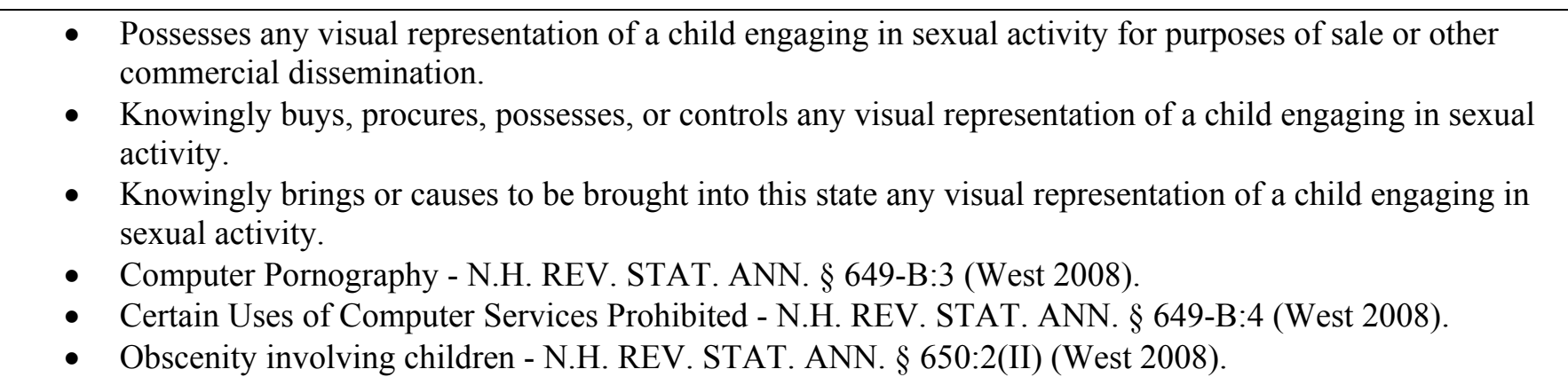 \\
\hline $\begin{array}{l}\text { Sex Offender Registration } \\
\text { Required for Staff Sexual } \\
\text { Misconduct? } \\
\text { (New Hampshire) }\end{array}$ & $\begin{array}{l}\text { YES. } \\
\text { N.H. REV. STAT. } \S 632-A: 2 \text { (West 2008) } \\
\text { Aggravated Felonious Sexual Assault. } \\
\text { I. A person is guilty of the felony of aggravated felonious sexual assault if such person engages in sexual } \\
\text { penetration with another person under any of the following circumstances: } \\
\text { (n) When the actor is in a position of authority over the victim and uses this authority to coerce the victim to } \\
\text { submit under any of the following circumstances: } \\
\text { (1) When the actor has direct supervisory or disciplinary authority over the victim by virtue of the victim } \\
\text { being incarcerated in a correctional institution, the secure psychiatric unit, or juvenile detention facility } \\
\text { where the actor is employed; or } \\
\text { (2) When the actor is a probation or parole officer or a juvenile probation and parole officer who has direct } \\
\text { supervisory or disciplinary authority over the victim while the victim is on parole or probation or under } \\
\text { juvenile probation. } \\
\text { Consent of the victim under any of the circumstances set forth in subparagraph (n) shall not be considered a }\end{array}$ \\
\hline
\end{tabular}

** Denotes those states where sex offender registration is required for convictions under the staff sexual misconduct laws of the states. Staff and 138 inmates could also be required to register as sex offenders if the offense were charged under other registrable offenses.

This publication is developed by the NIC/WCL Project on Addressing Prison Rape under NIC Cooperative Agreement 06S20GJJ1.

This is not to be posted or reproduced without permission from the authors.

American University, Washington College of Law

Current as of August 2009 


\section{Fifty State Survey of Adult Sex Offender Registration Requirements}

\section{NIC/WCL Project on Addressing Prison Rape}

\begin{tabular}{|c|c|}
\hline $\begin{array}{l}\text { Sex Offender Registration } \\
\text { Required for Staff Sexual } \\
\text { Misconduct? Cont'd } \\
\text { (New Hampshire) }\end{array}$ & $\begin{array}{l}\text { defense. } \\
\text { N.H. REV. STAT. § 632-A:3 (West 2008) } \\
\text { Felonious Sexual Assault. } \\
\text { A person is guilty of a class B felony if such person: } \\
\text { I. Subjects a person to sexual contact and causes serious personal injury to the victim under any of the } \\
\text { circumstances named in RSA 632-A:2; or } \\
\text { IV. Engages in sexual contact with the person when the actor is in a position of authority over the person and uses } \\
\text { that authority to coerce the victim to submit under any of the following circumstances: } \\
\text { (a) When the actor has direct supervisory or disciplinary authority over the victim by virtue of the victim being } \\
\text { incarcerated in a correctional institution, the secure psychiatric unit, or juvenile detention facility where the actor is } \\
\text { employed; or } \\
\text { (b) When the actor is a probation or parole officer or a juvenile probation and parole officer who has direct } \\
\text { supervisory or disciplinary authority over the victim while the victim is on parole or probation or under juvenile } \\
\text { probation. } \\
\text { Consent of the victim under any of the circumstances set forth in paragraph IV shall not be considered a defense. }\end{array}$ \\
\hline $\begin{array}{l}\text { Information Maintained in } \\
\text { Sex Offender Registry } \\
\text { (New Hampshire) }\end{array}$ & $\begin{array}{l}\text { N.H. REV. STAT. } \S 651-B: 4 \\
\text { I. } \\
\text { - name } \\
\text { - aliases } \\
\text { - current mailing address } \\
\text { - place of residence } \\
\text { - place of employment or schooling } \\
\text { - photograph }\end{array}$ \\
\hline
\end{tabular}

** Denotes those states where sex offender registration is required for convictions under the staff sexual misconduct laws of the states. Staff and 139 inmates could also be required to register as sex offenders if the offense were charged under other registrable offenses.

This publication is developed by the NIC/WCL Project on Addressing Prison Rape under NIC Cooperative Agreement 06S20GJJ1.

This is not to be posted or reproduced without permission from the authors.

American University, Washington College of Law

Current as of August 2009 


\section{Fifty State Survey of Adult Sex Offender Registration Requirements}

\section{NIC/WCL Project on Addressing Prison Rape}

\begin{tabular}{|c|c|}
\hline $\begin{array}{l}\text { Community Notification } \\
\text { and Websites } \\
\text { (New Hampshire) }\end{array}$ & $\begin{array}{l}\text { N.H. REV. STAT. } § 651-B: 7 \\
\text { I. } \\
\text { - Except as provided in this section, the records established and information collected pursuant to the provisions of } \\
\text { this chapter shall not be considered "public records" subject to inspection. } \\
\text { - However, nothing in this chapter shall be construed to limit any law enforcement agency from making any use or } \\
\text { disclosure of any such information as may be necessary to the performance of a valid law enforcement function. } \\
\text { - Nothing in this chapter shall be construed to limit an individual's ability to obtain access to the individual's own } \\
\text { records, or to limit access to a person's criminal record including address information obtained under the } \\
\text { provisions of this chapter. } \\
\text { IV. (a) } \\
\text { - The division shall provide a copy of the list described in this section to each local law enforcement agency at } \\
\text { periodic intervals, through written, electronic, computerized, or other accessible means, but in no event less } \\
\text { frequently than once each month. } \\
\text { - The list shall be made available to interested members of the public upon request to a local law enforcement } \\
\text { agency. } \\
\text { - The department of safety may make the list available to interested members of the public through the use of the } \\
\text { department's official public Internet access site. } \\
\text { - The department shall adopt rules, establishing procedures for the collection of information described in this } \\
\text { section, the transmission of the information from the division to the local law enforcement agencies, and the } \\
\text { conditions under which the list shall be made available to the public. } \\
\text { - These rules shall enable the public to request information about a named individual or about all listed individuals } \\
\text { residing or confined in the state. } \\
\text { - The rules may also include provisions for the imposition of a reasonable fee to defray the administrative costs of } \\
\text { collecting the information and making the information available to the public. }\end{array}$ \\
\hline $\begin{array}{l}\text { Limitations on Residency or } \\
\text { Employment } \\
\text { (New Hampshire) }\end{array}$ & None. \\
\hline
\end{tabular}

** Denotes those states where sex offender registration is required for convictions under the staff sexual misconduct laws of the states. Staff and 140 inmates could also be required to register as sex offenders if the offense were charged under other registrable offenses.

This publication is developed by the NIC/WCL Project on Addressing Prison Rape under NIC Cooperative Agreement 06S20GJJ1.

This is not to be posted or reproduced without permission from the authors.

American University, Washington College of Law

Current as of August 2009 


\section{Fifty State Survey of Adult Sex Offender Registration Requirements}

\section{NIC/WCL Project on Addressing Prison Rape}

\begin{tabular}{|c|c|}
\hline $\begin{array}{l}\text { Duration of Registration } \\
\text { (New Hampshire) }\end{array}$ & $\begin{array}{l}\text { N.H. REV. STAT. } \$ 651-B: 6 \\
\text { I. } 10 \text { years for offenders not subject to lifetime registration. } \\
\text { Life for persons convicted of: } \\
\text { - Aggravated sexual assault; } \\
\text { - Felonious sexual assault; } \\
\text { - Indecent exposure and lewdness } \\
\text { - Intentional contribution to delinquency; } \\
\text { - Kidnapping; } \\
\text { - Criminal restraint; } \\
\text { - Incest; } \\
\text { - Prostitution and related offenses: } \\
\text { - Child pornography; } \\
\text { - Computer pornography; or } \\
\text { - Obscenity involving children. } \\
\text { Life for persons with } 2 \text { or more convictions for a registrable offense. }\end{array}$ \\
\hline & NEW JERSEY** \\
\hline $\begin{array}{l}\text { Registrable Offenses } \\
\text { (New Jersey) }\end{array}$ & 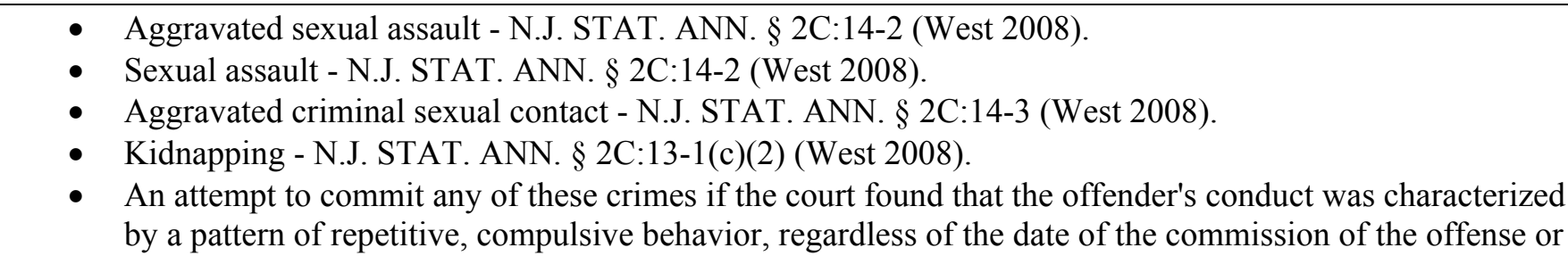 \\
\hline
\end{tabular}

** Denotes those states where sex offender registration is required for convictions under the staff sexual misconduct laws of the states. Staff and 141 inmates could also be required to register as sex offenders if the offense were charged under other registrable offenses.

This publication is developed by the NIC/WCL Project on Addressing Prison Rape under NIC Cooperative Agreement 06S20GJJ1.

This is not to be posted or reproduced without permission from the authors.

American University, Washington College of Law

Current as of August 2009 


\section{Fifty State Survey of Adult Sex Offender Registration Requirements}

\section{NIC/WCL Project on Addressing Prison Rape}

\begin{tabular}{|c|c|}
\hline $\begin{array}{l}\text { Registrable Offenses Cont'd } \\
\text { (New Jersey) }\end{array}$ & 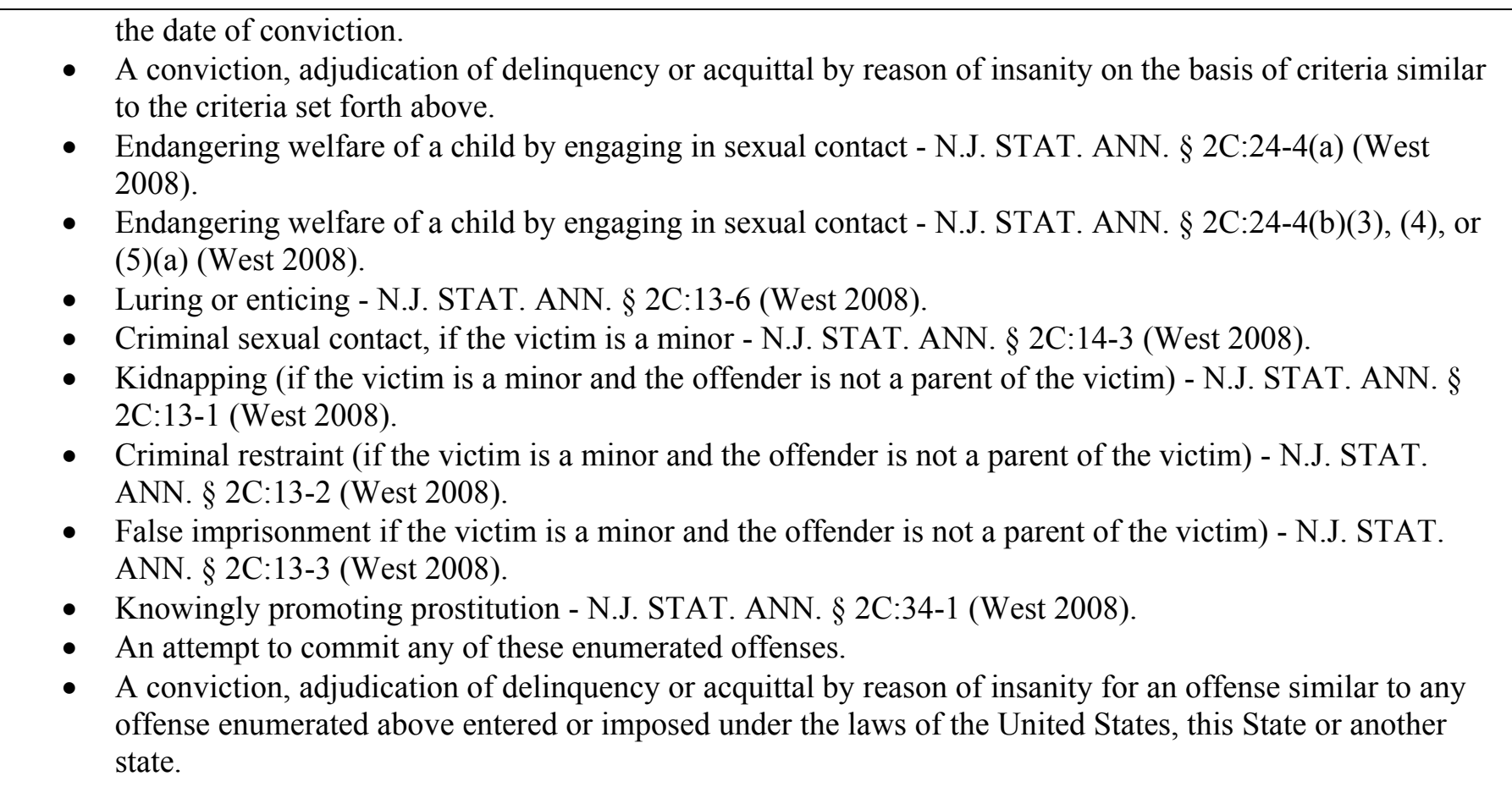 \\
\hline $\begin{array}{l}\text { Sex Offender Registration } \\
\text { Required for Staff Sexual } \\
\text { Misconduct? } \\
\text { (New Jersey) }\end{array}$ & $\begin{array}{l}\text { YES. } \\
\text { N.J.S.A. § } 2 \text { C:14-2 (West 2008) } \\
\text { Sexual Assault } \\
\text { c. An actor is guilty of sexual assault if he commits an act of sexual penetration with another person under any one } \\
\text { of the following circumstances: } \\
\quad \text { (2) The victim is on probation or parole, or is detained in a hospital, prison or other institution and the actor }\end{array}$ \\
\hline
\end{tabular}

** Denotes those states where sex offender registration is required for convictions under the staff sexual misconduct laws of the states. Staff and inmates could also be required to register as sex offenders if the offense were charged under other registrable offenses.

This publication is developed by the NIC/WCL Project on Addressing Prison Rape under NIC Cooperative Agreement 06S20GJJ1.

This is not to be posted or reproduced without permission from the authors.

American University, Washington College of Law

Current as of August 2009 


\section{Fifty State Survey of Adult Sex Offender Registration Requirements}

\section{NIC/WCL Project on Addressing Prison Rape}

\begin{tabular}{|c|c|}
\hline $\begin{array}{l}\text { Sex Offender Registration } \\
\text { Required for Staff Sexual } \\
\text { Misconduct? Cont'd } \\
\text { (New Jersey) }\end{array}$ & $\begin{array}{l}\text { has supervisory or disciplinary power over the victim by virtue of the actor's legal, professional or } \\
\text { occupational status; } \\
\text { OR } \\
\text { (3) The victim is at least } 16 \text { but less than } 18 \text { years old and: (b) The actor has supervisory or disciplinary } \\
\text { power of any nature or in any capacity over the victim; or }\end{array}$ \\
\hline $\begin{array}{l}\text { Information Maintained in } \\
\text { Sex Offender Registry } \\
\text { (New Jersey) }\end{array}$ & $\begin{array}{l}\text { N.J.S.A. } \$ 2 \text { C:7-4 (West 2008) } \\
\text { b. The form of registration required by this act shall include: } \\
\text { (1) A statement in writing signed by the person required to register acknowledging that the person has been } \\
\text { advised of the duty to register and reregister imposed by this act and including the person's name, social } \\
\text { security number, age, race, sex, date of birth, height, weight, hair and eye color, address of legal residence, } \\
\text { address of any current temporary residence, date and place of employment; and any anticipated or current } \\
\text { school enrollment, including but not limited to enrollment at or employment by any institution of higher } \\
\text { education; } \\
\text { (2) Date and place of each conviction, adjudication or acquittal by reason of insanity, indictment number, } \\
\text { fingerprints, and a brief description of the crime or crimes for which registration is required; and } \\
\text { (3) Any other information that the Attorney General deems necessary to assess risk of future commission of } \\
\text { a crime, including criminal and corrections records, nonprivileged personnel, treatment, and abuse registry } \\
\text { records, and evidentiary genetic markers when available. }\end{array}$ \\
\hline $\begin{array}{l}\text { Community Notification } \\
\text { and Websites } \\
\text { (New Jersey) }\end{array}$ & $\begin{array}{l}\text { N.J.S.A. 2C:7-6 (West 2008) } \\
\text { - Within } 45 \text { days after receiving notification that an inmate convicted of or adjudicated delinquent for a sex }\end{array}$ \\
\hline
\end{tabular}

** Denotes those states where sex offender registration is required for convictions under the staff sexual misconduct laws of the states. Staff and inmates could also be required to register as sex offenders if the offense were charged under other registrable offenses.

This publication is developed by the NIC/WCL Project on Addressing Prison Rape under NIC Cooperative Agreement 06S20GJJ1.

This is not to be posted or reproduced without permission from the authors.

American University, Washington College of Law

Current as of August 2009 


\section{Fifty State Survey of Adult Sex Offender Registration Requirements}

\section{NIC/WCL Project on Addressing Prison Rape}

\begin{tabular}{|c|c|}
\hline $\begin{array}{l}\text { Community Notification and } \\
\text { Websites Cont'd } \\
\text { (New Jersey) }\end{array}$ & $\begin{array}{l}\text { offense is to be released from incarceration and after receipt of registration as required therein, the chief law } \\
\text { enforcement officer of the municipality where the inmate intends to reside shall provide notification of that } \\
\text { inmate's release to the community. } \\
\text { - If the municipality does not have a police force, the Superintendent of State Police shall provide notification. } \\
\text { N.J.S.A. } 2 \text { C:7-13 (West 2008) } \\
\text { a. Pursuant to the provisions of this section, the Superintendent of State Police shall develop and maintain a } \\
\text { system for making certain information in the central registry publicly available by means of electronic } \\
\text { Internet technology. }\end{array}$ \\
\hline $\begin{array}{l}\text { Limitations on Residency or } \\
\text { Employment } \\
\text { (New Jersey) }\end{array}$ & None. \\
\hline $\begin{array}{l}\text { Duration of Registration } \\
\text { (New Jersey) }\end{array}$ & $\begin{array}{l}\text { N.J.S.A. 2C:7-2 (WEST 2008) } \\
\text { (f) Sex offenders may petition for termination of the obligation to register upon proof that they have not committed } \\
\text { an offense within } 15 \text { years following release from incarceration. } \\
\text { Offenders convicted or adjudicated delinquent for more than one sex offense or an aggravated sexual assault are not } \\
\text { eligible for termination of the obligation to register and, therefore, must register for life. }\end{array}$ \\
\hline & NEW MEXICO** \\
\hline $\begin{array}{l}\text { Registrable Offenses } \\
(\mathrm{New} \text { Mexico) }\end{array}$ & $\begin{array}{l}\text { - } \text { Criminal sexual penetration (1st, 2nd, 3rd, 4th degree) - N.M. STAT. ANN. § 30-9-11 (West 2008). } \\
\text { - } \quad \text { Criminal sexual contact (4th degree) - N.M. STAT. ANN. § 30-9-12 (West 2008). } \\
\text { - } \quad \text { Criminal sexual contact of a minor (2nd, 3rd, 4th degree) - N.M. STAT. ANN. § 30-9-13 (West 2008). }\end{array}$ \\
\hline
\end{tabular}

** Denotes those states where sex offender registration is required for convictions under the staff sexual misconduct laws of the states. Staff and 144 inmates could also be required to register as sex offenders if the offense were charged under other registrable offenses.

This publication is developed by the NIC/WCL Project on Addressing Prison Rape under NIC Cooperative Agreement 06S20GJJ1.

This is not to be posted or reproduced without permission from the authors.

American University, Washington College of Law

Current as of August 2009 


\section{Fifty State Survey of Adult Sex Offender Registration Requirements}

\section{NIC/WCL Project on Addressing Prison Rape}

\begin{tabular}{|c|c|}
\hline $\begin{array}{l}\text { Registrable Offenses } \\
\text { (New Mexico) }\end{array}$ & 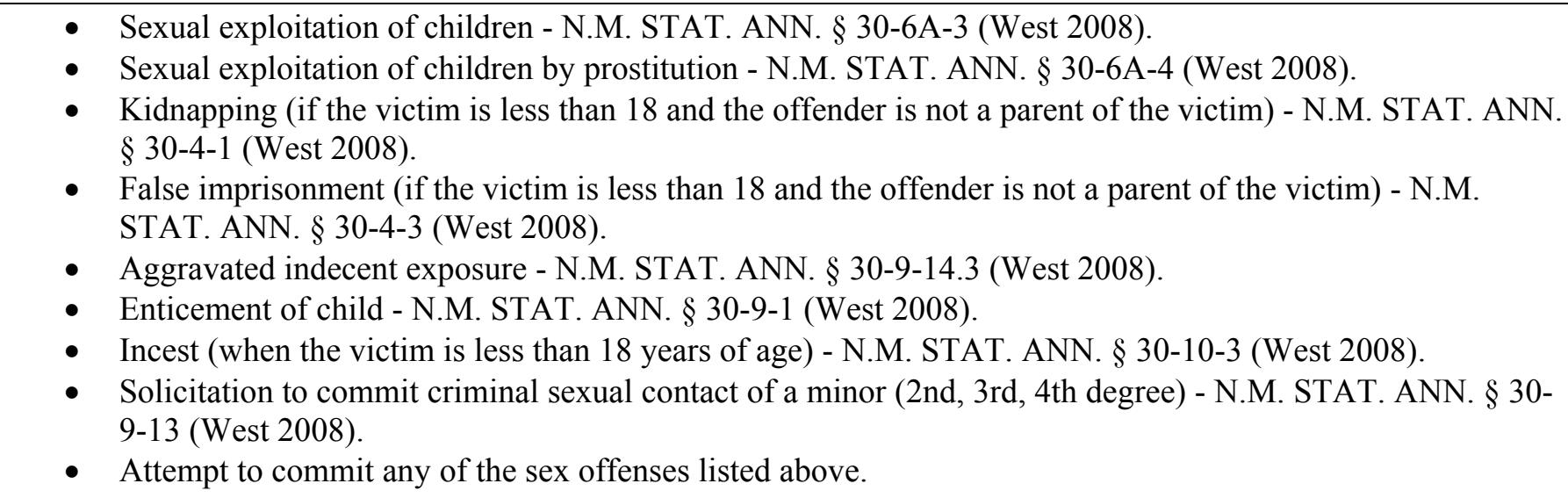 \\
\hline $\begin{array}{l}\text { Sex Offender Registration } \\
\text { Required for Staff Sexual } \\
\text { Misconduct? } \\
\text { (New Mexico) }\end{array}$ & $\begin{array}{l}\text { YES. } \\
\text { N.M.S.A. 1978, §30-9-11 (West 2008) } \\
\text { Second Degree Criminal Sexual Penetration. } \\
\text { D. Criminal sexual penetration in the first degree consists of all criminal sexual penetration perpetrated: } \\
\quad \text { (2) by the use of force or coercion that results in great bodily harm or great mental anguish to the victim. }\end{array}$ \\
\hline $\begin{array}{l}\text { Information Maintained in } \\
\text { Sex Offender Registry } \\
\text { (New Mexico) }\end{array}$ & $\begin{array}{l}\text { N.M.S.A. 1978, § 29-11A-4 (West 2008). } \\
\text { B. When a sex offender registers with the county sheriff, he shall provide the following registration information: } \\
\text { (1) his legal name and any other names or aliases that he is using or has used; } \\
\text { (2) his date of birth; } \\
\text { (3) his social security number; } \\
\text { (4) his current address; }\end{array}$ \\
\hline
\end{tabular}

** Denotes those states where sex offender registration is required for convictions under the staff sexual misconduct laws of the states. Staff and inmates could also be required to register as sex offenders if the offense were charged under other registrable offenses.

This publication is developed by the NIC/WCL Project on Addressing Prison Rape under NIC Cooperative Agreement 06S20GJJ1.

This is not to be posted or reproduced without permission from the authors.

American University, Washington College of Law

Current as of August 2009 


\section{Fifty State Survey of Adult Sex Offender Registration Requirements}

\section{NIC/WCL Project on Addressing Prison Rape}

\begin{tabular}{|c|c|}
\hline $\begin{array}{l}\text { Information Maintained in } \\
\text { Sex Offender Registry } \\
\text { Cont'd } \\
\text { (New Mexico) }\end{array}$ & $\begin{array}{l}\text { (5) his place of employment; } \\
\text { (6) the sex offense for which he was convicted; and } \\
\text { (7) the date and place of his sex offense conviction. }\end{array}$ \\
\hline $\begin{array}{l}\text { Community Notification } \\
\text { and Websites } \\
(\mathrm{New} \text { Mexico) }\end{array}$ & $\begin{array}{l}\text { N.M.S.A. 1978, } \S 29-11 \text { A-5.1 (West 2008). } \\
\text { A. If a sex offender is convicted of one of the sex offenses, the county sheriff shall forward registration information } \\
\text { obtained from the sex offender to the district attorney for the judicial district in which the sex offender resides and, } \\
\text { if the sex offender is a resident of a municipality, the chief law enforcement officer for the municipality in which } \\
\text { the sex offender resides: } \\
\text { B. A person who wants to obtain registration information regarding sex offenders described in Subsection A of this } \\
\text { section may request that information from the: } \\
\text { (1) sheriff for the county in which the sex offenders reside; } \\
\text { (2) chief law enforcement officer for the municipality in which the sex offenders reside; } \\
\text { (3) district attorney for the judicial district in which the sex offenders reside; or } \\
\text { (4) secretary of public safety. } \\
\text { E. The department of public safety shall establish and manage an internet web site that provides the public with } \\
\text { registration information regarding sex offenders described in Subsection A of this section, except that the } \\
\text { department of public safety shall not provide registration information on the internet web site regarding a sex } \\
\text { offender who was less than eighteen years of age when he committed the sex offense for which he was convicted } \\
\text { as a youthful offender, unless at the time of sentencing, the court made a finding that the sex offender is not } \\
\text { amenable to treatment and is a danger to the community. } \\
\text { - The registration information provided to the public pursuant to this subsection shall not include a sex offender's } \\
\text { social security number or DNA information or a sex offender's place of employment, unless the sex offender's } \\
\text { employment requires him to have direct contact with children. }\end{array}$ \\
\hline
\end{tabular}

** Denotes those states where sex offender registration is required for convictions under the staff sexual misconduct laws of the states. Staff and inmates could also be required to register as sex offenders if the offense were charged under other registrable offenses.

This publication is developed by the NIC/WCL Project on Addressing Prison Rape under NIC Cooperative Agreement 06S20GJJ1.

This is not to be posted or reproduced without permission from the authors.

American University, Washington College of Law

Current as of August 2009 


\section{Fifty State Survey of Adult Sex Offender Registration Requirements}

\section{NIC/WCL Project on Addressing Prison Rape}

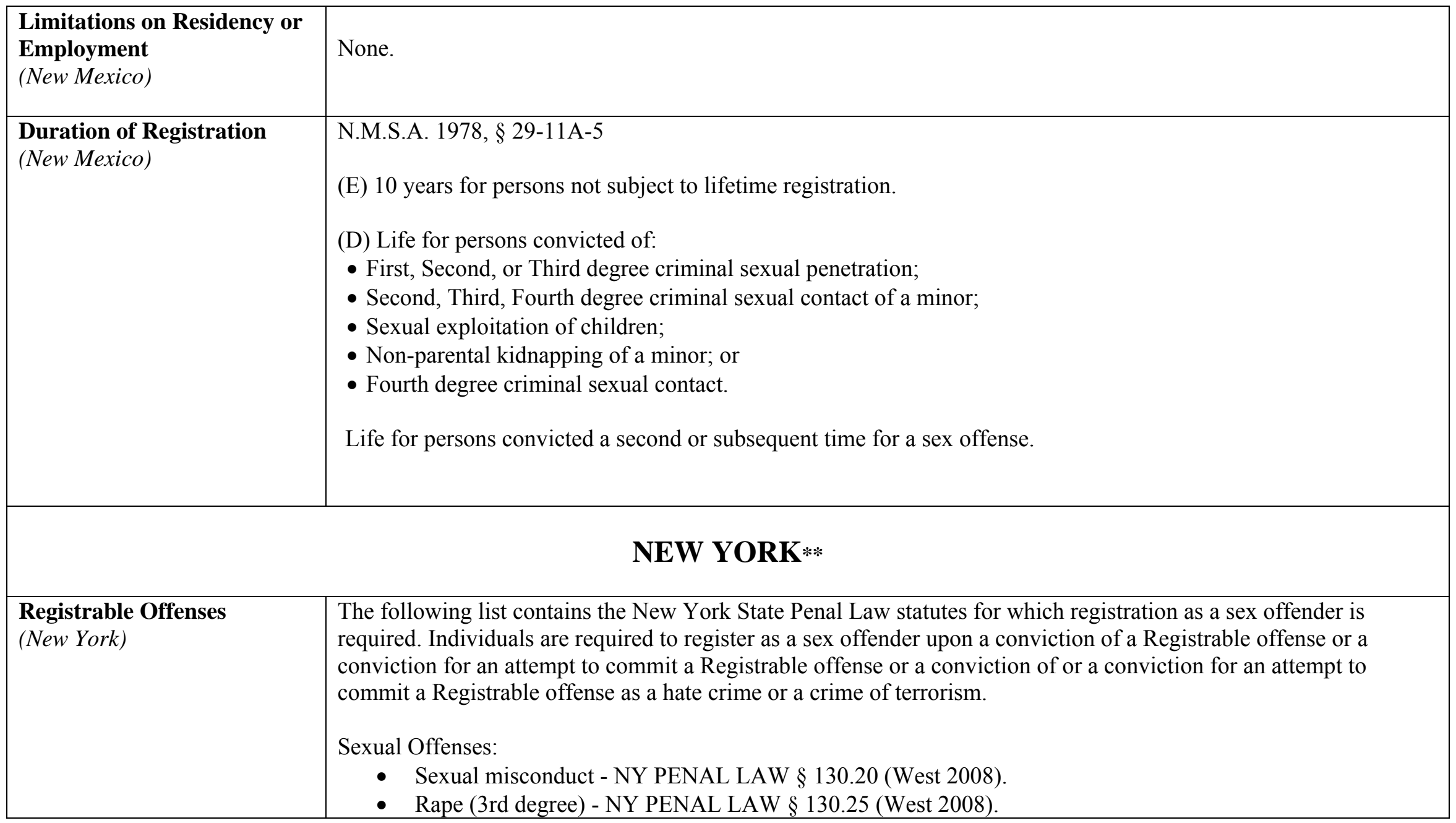

** Denotes those states where sex offender registration is required for convictions under the staff sexual misconduct laws of the states. Staff and inmates could also be required to register as sex offenders if the offense were charged under other registrable offenses.

This publication is developed by the NIC/WCL Project on Addressing Prison Rape under NIC Cooperative Agreement 06S20GJJ1.

This is not to be posted or reproduced without permission from the authors.

American University, Washington College of Law

Current as of August 2009 


\section{Fifty State Survey of Adult Sex Offender Registration Requirements}

\section{NIC/WCL Project on Addressing Prison Rape}

\begin{tabular}{|c|c|}
\hline $\begin{array}{l}\text { Registrable Offenses Cont'd } \\
(\text { New York) }\end{array}$ & 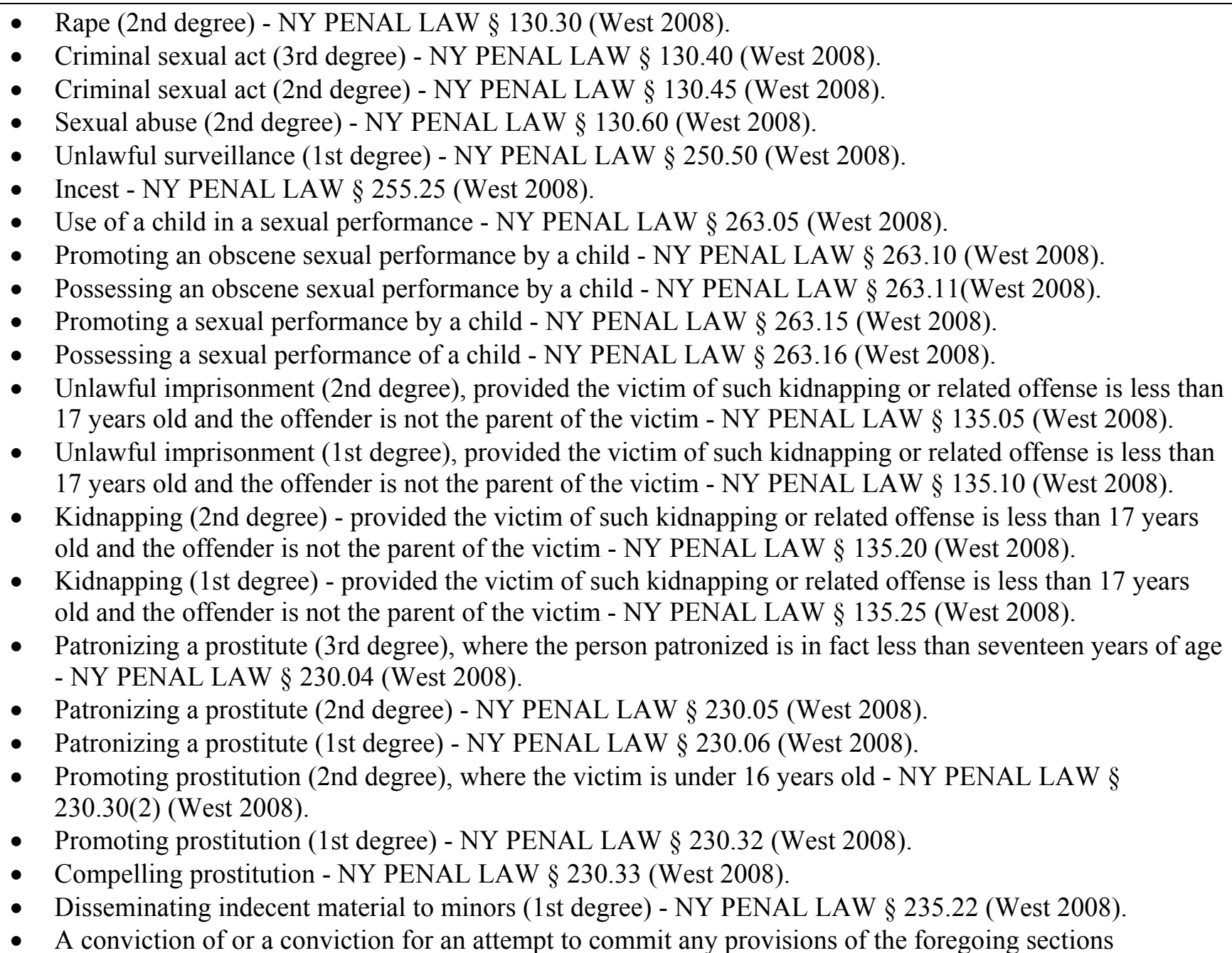 \\
\hline
\end{tabular}

** Denotes those states where sex offender registration is required for convictions under the staff sexual misconduct laws of the states. Staff and 148 inmates could also be required to register as sex offenders if the offense were charged under other registrable offenses.

This publication is developed by the NIC/WCL Project on Addressing Prison Rape under NIC Cooperative Agreement 06S20GJJ1.

This is not to be posted or reproduced without permission from the authors.

American University, Washington College of Law

Current as of August 2009 


\section{Fifty State Survey of Adult Sex Offender Registration Requirements}

\section{NIC/WCL Project on Addressing Prison Rape}

\begin{tabular}{|c|c|}
\hline $\begin{array}{l}\text { Registrable Offenses Cont'd } \\
\text { (New York) }\end{array}$ & 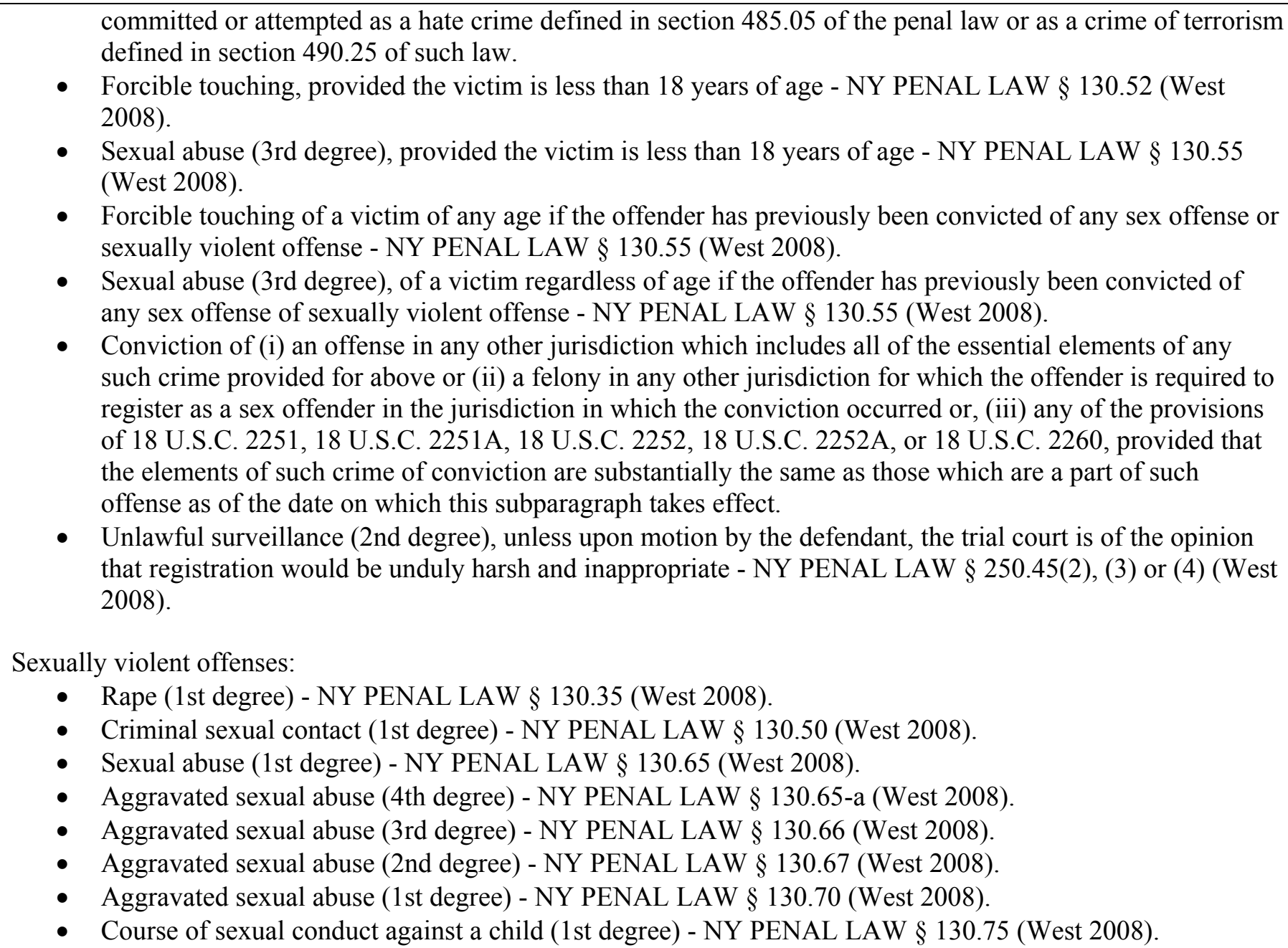 \\
\hline
\end{tabular}

** Denotes those states where sex offender registration is required for convictions under the staff sexual misconduct laws of the states. Staff and inmates could also be required to register as sex offenders if the offense were charged under other registrable offenses.

This publication is developed by the NIC/WCL Project on Addressing Prison Rape under NIC Cooperative Agreement 06S20GJJ1.

This is not to be posted or reproduced without permission from the authors.

American University, Washington College of Law

Current as of August 2009 


\section{Fifty State Survey of Adult Sex Offender Registration Requirements}

\section{NIC/WCL Project on Addressing Prison Rape}

\begin{tabular}{|c|c|}
\hline $\begin{array}{l}\text { Registrable Offenses Cont'd } \\
\text { (New York) }\end{array}$ & 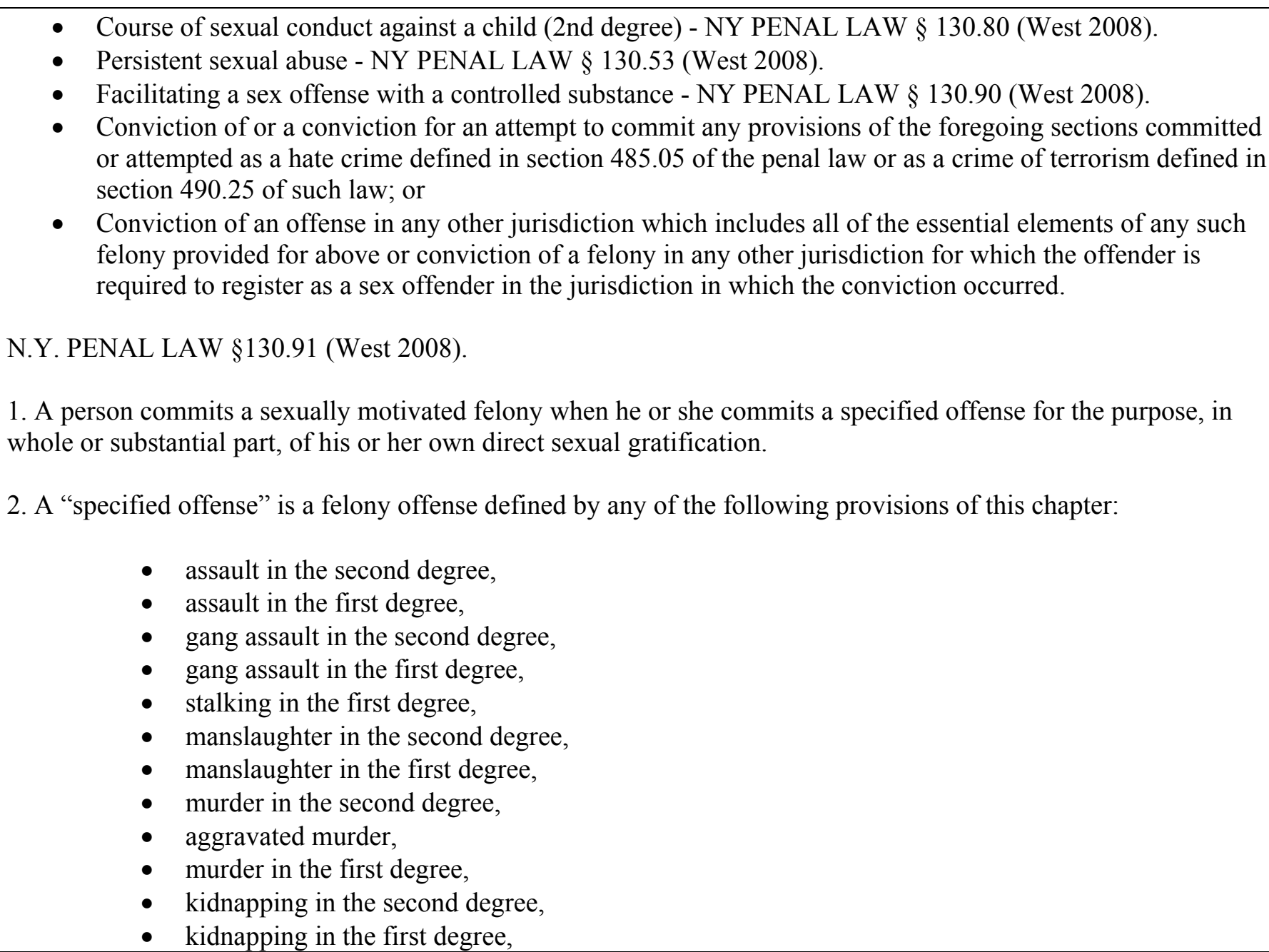 \\
\hline
\end{tabular}

** Denotes those states where sex offender registration is required for convictions under the staff sexual misconduct laws of the states. Staff and inmates could also be required to register as sex offenders if the offense were charged under other registrable offenses.

This publication is developed by the NIC/WCL Project on Addressing Prison Rape under NIC Cooperative Agreement 06S20GJJ1.

This is not to be posted or reproduced without permission from the authors.

American University, Washington College of Law

Current as of August 2009 


\section{Fifty State Survey of Adult Sex Offender Registration Requirements}

\section{NIC/WCL Project on Addressing Prison Rape}

\begin{tabular}{|c|c|}
\hline $\begin{array}{l}\text { Registrable Offenses Cont'd } \\
(\text { New York) }\end{array}$ & $\begin{array}{l}\text { - burglary in the third degree, } \\
\text { - burglary in the second degree, } \\
\text { - } \text { burglary in the first degree, } \\
\text { - arson in the second degree, } \\
\text { - robbery in the third degree, } \\
\text { - robbery in the second degree, } \\
\text { - } \text { promoting prostitution in the second degree, } \\
\text { - promoting prostitution in the first degree, } \\
\text { - compelling prostitution, } \\
\text { - disseminating indecent material to minors in the first degree, } \\
\text { - use of a child in a sexual performance, } \\
\text { - promoting an obscene sexual performance by a child, } \\
\text { - or any felony attempt or conspiracy to commit any of the foregoing offenses. }\end{array}$ \\
\hline $\begin{array}{l}\text { Sex Offender Registration } \\
\text { Required for Staff Sexual } \\
\text { Misconduct? } \\
(\text { New York) }\end{array}$ & $\begin{array}{l}\text { YES } \\
\text { N.Y. PENAL LAW } \S 130.20 \text { (West 2008). } \\
\text { Sexual misconduct. } \\
\text { A person is guilty of sexual misconduct when: } \\
\text { 1. He or she engages in sexual intercourse with another person without such person's consent; or } \\
\text { 2. He or she engages in oral sexual conduct or anal sexual conduct with another person without such person's } \\
\text { consent; or }\end{array}$ \\
\hline
\end{tabular}

** Denotes those states where sex offender registration is required for convictions under the staff sexual misconduct laws of the states. Staff and 151 inmates could also be required to register as sex offenders if the offense were charged under other registrable offenses.

This publication is developed by the NIC/WCL Project on Addressing Prison Rape under NIC Cooperative Agreement 06S20GJJ1.

This is not to be posted or reproduced without permission from the authors.

American University, Washington College of Law

Current as of August 2009 


\section{Fifty State Survey of Adult Sex Offender Registration Requirements}

\section{NIC/WCL Project on Addressing Prison Rape}

\begin{tabular}{|c|c|}
\hline $\begin{array}{l}\text { Sex Offender Registration } \\
\text { Required for Staff Sexual } \\
\text { Misconduct? Cont'd } \\
\text { (New York) }\end{array}$ & 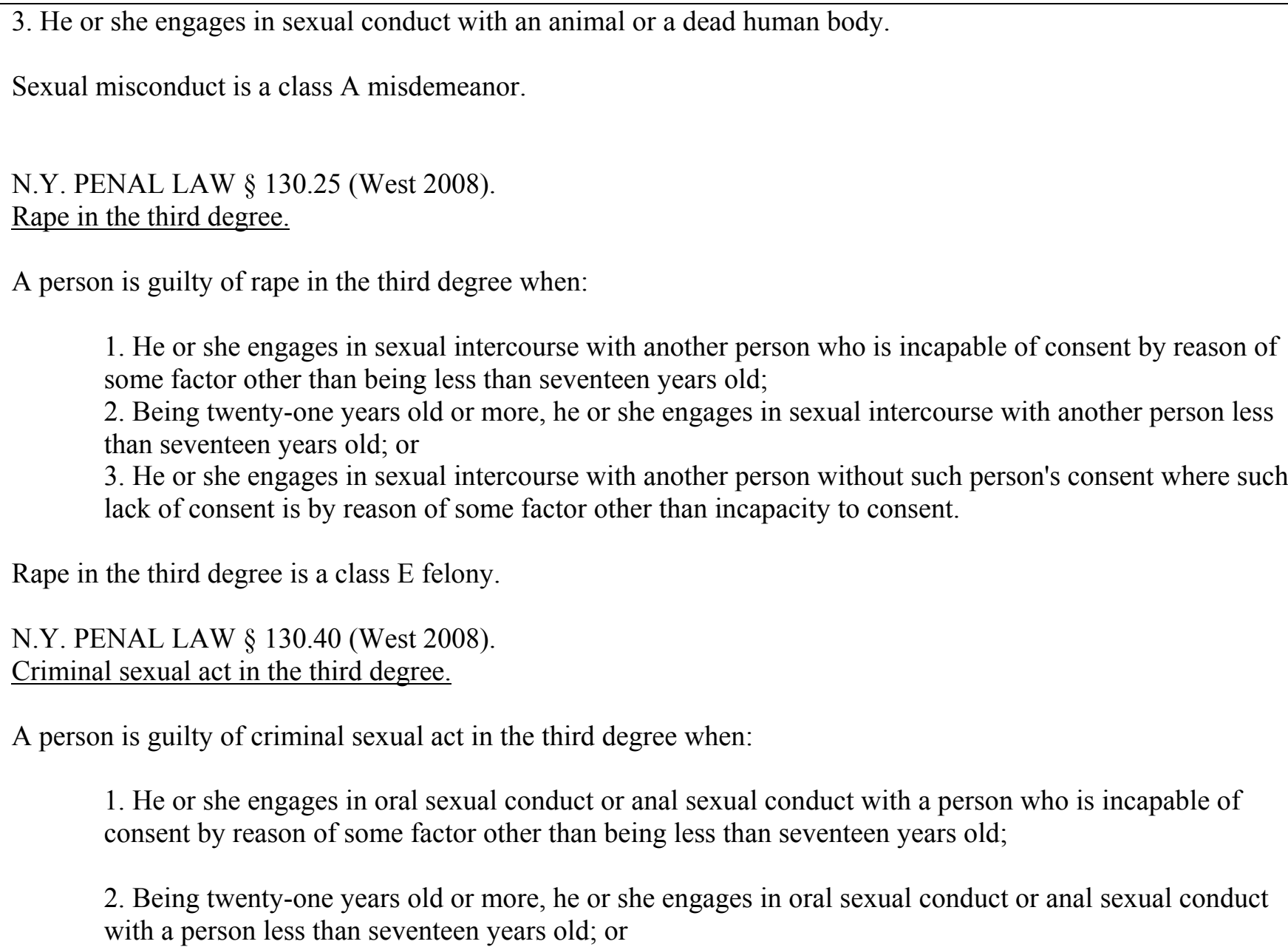 \\
\hline
\end{tabular}

** Denotes those states where sex offender registration is required for convictions under the staff sexual misconduct laws of the states. Staff and inmates could also be required to register as sex offenders if the offense were charged under other registrable offenses.

This publication is developed by the NIC/WCL Project on Addressing Prison Rape under NIC Cooperative Agreement 06S20GJJ1.

This is not to be posted or reproduced without permission from the authors.

American University, Washington College of Law

Current as of August 2009 


\section{Fifty State Survey of Adult Sex Offender Registration Requirements}

\section{NIC/WCL Project on Addressing Prison Rape}

\begin{tabular}{|c|c|}
\hline $\begin{array}{l}\text { Sex Offender Registration } \\
\text { Required for Staff Sexual } \\
\text { Misconduct? Cont'd } \\
(\text { New York) }\end{array}$ & $\begin{array}{l}\text { 3. He or she engages in oral sexual conduct or anal sexual conduct with another person without such } \\
\text { person's consent where such lack of consent is by reason of some factor other than incapacity to consent. } \\
\text { Criminal sexual act in the third degree is a class E felony. }\end{array}$ \\
\hline $\begin{array}{l}\text { Information Maintained in } \\
\text { Sex Offender Registry } \\
\text { (New York) }\end{array}$ & $\begin{array}{l}\text { NY CORRECT } \S 168 \text {-b (West 2008) } \\
\text { 1. The division shall establish and maintain a file of individuals required to register pursuant to the provisions of } \\
\text { this article which shall include the following information of each registrant: } \\
\text { (a) The sex offender's name, all aliases used, date of birth, sex, race, height, weight, eye color, driver's } \\
\text { license number, home address and/or expected place of domicile, any internet accounts with internet access } \\
\text { providers belonging to such offender and internet identifiers that such offender uses. } \\
\text { (b) A photograph and set of fingerprints. For a sex offender given a level three designation, the division } \\
\text { shall, during the period of registration, update such photograph once each year. For a sex offender given a } \\
\text { level one or level two designation, the division shall, during the period of registration, update such } \\
\text { photograph once every three years. The division shall notify the sex offender by mail of the duty to appear } \\
\text { and be photographed at the specified law enforcement agency having jurisdiction. Such notification shall be } \\
\text { mailed at least thirty days and not more than sixty days before the photograph is required to be taken } \\
\text { pursuant to subdivision two of section one hundred sixty-eight-f of this article. } \\
\text { (c) A description of the offense for which the sex offender was convicted, the date of conviction and the } \\
\text { sentence imposed. } \\
\text { (d) The name and address of any institution of higher education at which the sex offender is or expects to be } \\
\text { enrolled, attending or employed, whether for compensation or not, and whether such offender resides in or } \\
\text { will reside in a facility owned or operated by such institution. } \\
\text { (e) If the sex offender has been given a level three designation, such offender's employment address and/or }\end{array}$ \\
\hline
\end{tabular}

** Denotes those states where sex offender registration is required for convictions under the staff sexual misconduct laws of the states. Staff and 153 inmates could also be required to register as sex offenders if the offense were charged under other registrable offenses.

This publication is developed by the NIC/WCL Project on Addressing Prison Rape under NIC Cooperative Agreement 06S20GJJ1.

This is not to be posted or reproduced without permission from the authors.

American University, Washington College of Law

Current as of August 2009 


\section{Fifty State Survey of Adult Sex Offender Registration Requirements}

\section{NIC/WCL Project on Addressing Prison Rape}

\begin{tabular}{|c|c|}
\hline $\begin{array}{l}\text { Information Maintained in } \\
\text { Sex Offender Registry } \\
\text { Cont'd } \\
\text { (New York) }\end{array}$ & $\begin{array}{l}\text { expected place of employment. } \\
\text { (f) Any other information deemed pertinent by the division. }\end{array}$ \\
\hline $\begin{array}{l}\text { Community Notification } \\
\text { and Websites } \\
(\text { New York) }\end{array}$ & $\begin{array}{l}\text { NY CORRECT } \S \text { 168-b (WEST 2008) } \\
\text { 1. The division shall establish and maintain a file of individuals required to register pursuant to the provisions of } \\
\text { this article which shall include the following information of each registrant: } \\
\text { (a) The sex offender's name, all aliases used, date of birth, sex, race, height, weight, eye color, driver's license } \\
\text { number, home address and/or expected place of domicile, any internet accounts with internet access providers } \\
\text { belonging to such offender and internet identifiers that such offender uses. } \\
\text { (b) A photograph and set of fingerprints. For a sex offender given a level three designation, the division shall, } \\
\text { during the period of registration, update such photograph once each year. For a sex offender given a level one or } \\
\text { level two designation, the division shall, during the period of registration, update such photograph once every three } \\
\text { years. The division shall notify the sex offender by mail of the duty to appear and be photographed at the specified } \\
\text { law enforcement agency having jurisdiction. Such notification shall be mailed at least thirty days and not more than } \\
\text { sixty days before the photograph is required to be taken pursuant to subdivision two of section one hundred sixty- } \\
\text { eight of this article. } \\
\text { (c) A description of the offense for which the sex offender was convicted, the date of conviction and the sentence } \\
\text { imposed. } \\
\text { (d) The name and address of any institution of higher education at which the sex offender is or expects to be } \\
\text { enrolled, attending or employed, whether for compensation or not, and whether such offender resides in or will } \\
\text { reside in a facility owned or operated by such institution. } \\
\text { (e) If the sex offender has been given a level three designation, such offender's employment address and/or expected }\end{array}$ \\
\hline
\end{tabular}

** Denotes those states where sex offender registration is required for convictions under the staff sexual misconduct laws of the states. Staff and 154 inmates could also be required to register as sex offenders if the offense were charged under other registrable offenses.

This publication is developed by the NIC/WCL Project on Addressing Prison Rape under NIC Cooperative Agreement 06S20GJJ1.

This is not to be posted or reproduced without permission from the authors.

American University, Washington College of Law

Current as of August 2009 


\section{Fifty State Survey of Adult Sex Offender Registration Requirements}

\section{NIC/WCL Project on Addressing Prison Rape}

\begin{tabular}{|c|c|}
\hline $\begin{array}{l}\text { Community Notification } \\
\text { and Websites Cont'd } \\
\text { (New York) }\end{array}$ & 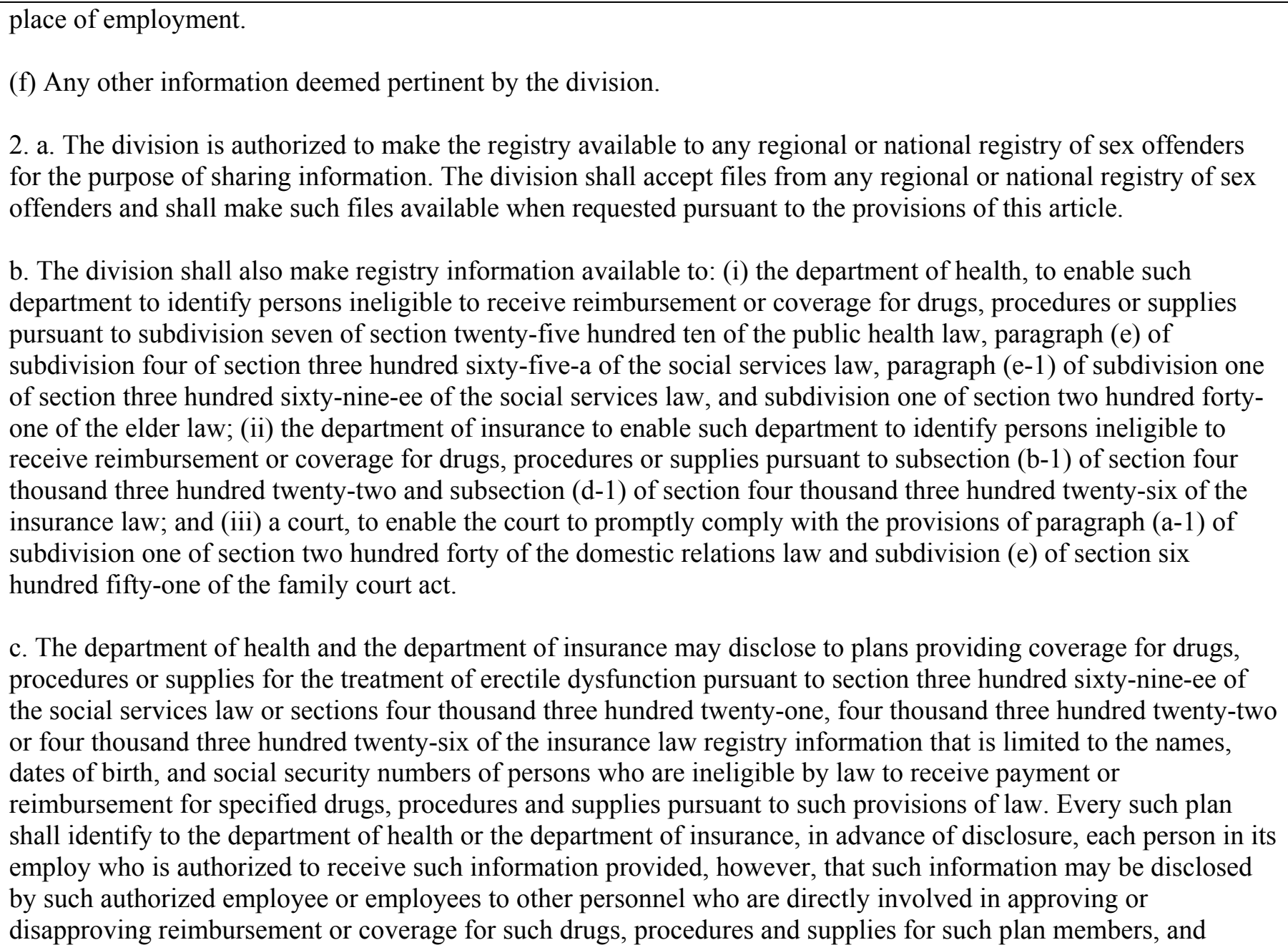 \\
\hline
\end{tabular}

** Denotes those states where sex offender registration is required for convictions under the staff sexual misconduct laws of the states. Staff and inmates could also be required to register as sex offenders if the offense were charged under other registrable offenses.

This publication is developed by the NIC/WCL Project on Addressing Prison Rape under NIC Cooperative Agreement 06S20GJJ1.

This is not to be posted or reproduced without permission from the authors.

American University, Washington College of Law

Current as of August 2009 


\section{Fifty State Survey of Adult Sex Offender Registration Requirements}

\section{NIC/WCL Project on Addressing Prison Rape}

\begin{tabular}{|c|c|}
\hline $\begin{array}{l}\text { Community Notification } \\
\text { and Websites Cont'd } \\
(\text { New York) }\end{array}$ & 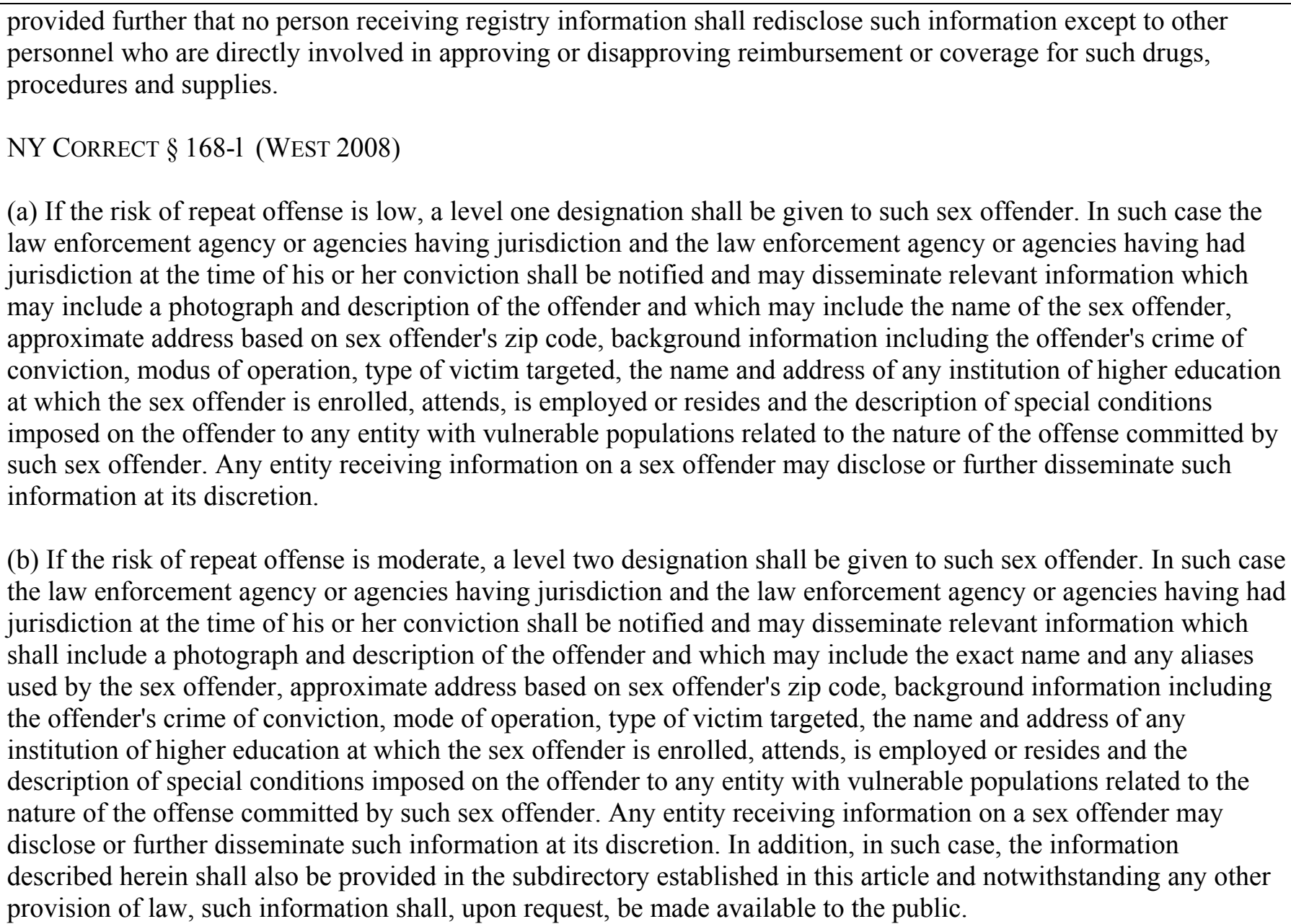 \\
\hline
\end{tabular}

** Denotes those states where sex offender registration is required for convictions under the staff sexual misconduct laws of the states. Staff and inmates could also be required to register as sex offenders if the offense were charged under other registrable offenses.

This publication is developed by the NIC/WCL Project on Addressing Prison Rape under NIC Cooperative Agreement 06S20GJJ1.

This is not to be posted or reproduced without permission from the authors.

American University, Washington College of Law

Current as of August 2009 


\section{Fifty State Survey of Adult Sex Offender Registration Requirements}

\section{NIC/WCL Project on Addressing Prison Rape}

\begin{tabular}{|c|c|}
\hline $\begin{array}{l}\text { Community Notification } \\
\text { and Websites Cont'd } \\
(\text { New York) }\end{array}$ & 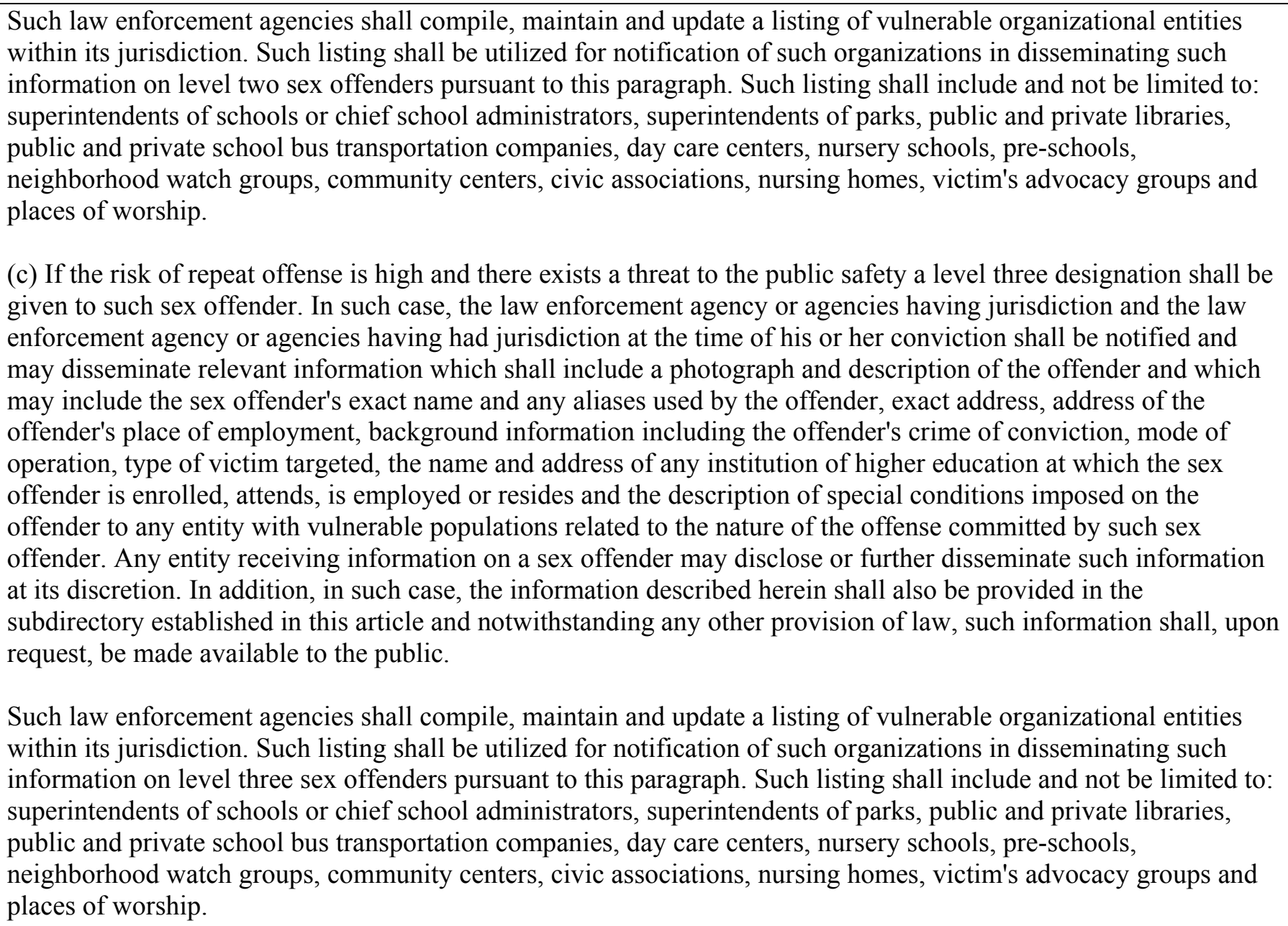 \\
\hline
\end{tabular}

** Denotes those states where sex offender registration is required for convictions under the staff sexual misconduct laws of the states. Staff and inmates could also be required to register as sex offenders if the offense were charged under other registrable offenses.

This publication is developed by the NIC/WCL Project on Addressing Prison Rape under NIC Cooperative Agreement 06S20GJJ1.

This is not to be posted or reproduced without permission from the authors.

American University, Washington College of Law

Current as of August 2009 


\section{Fifty State Survey of Adult Sex Offender Registration Requirements}

\section{NIC/WCL Project on Addressing Prison Rape}

\begin{tabular}{|c|c|}
\hline $\begin{array}{l}\text { Community Notification } \\
\text { and Websites Cont'd } \\
\text { (New York) }\end{array}$ & $\begin{array}{l}\text { NY CORRECT } § 168 \text {-p (WEST 2008) } \\
\text { Pursuant to section one hundred sixty-eight-b of this article, the division shall also operate a telephone number that } \\
\text { members of the public may call free of charge and inquire whether a named individual required to register pursuant } \\
\text { to this article is listed. The division shall ascertain whether a named person reasonably appears to be a person so } \\
\text { listed and provide the caller with the relevant information according to risk as described in subdivision six of } \\
\text { section one hundred sixty-eight of this article. The division shall decide whether the named person reasonably } \\
\text { appears to be a person listed, based upon information from the caller providing information that shall include (a) an } \\
\text { exact street address, including apartment number, driver's license number or birth date, along with additional } \\
\text { information that may include social security number, hair color, eye color, height, weight, distinctive markings, } \\
\text { ethnicity; or (b) any combination of the above listed characteristics if an exact birth date or address is not available. } \\
\text { If three of the characteristics provided include ethnicity, hair color, and eye color, other identifying characteristics } \\
\text { shall be provided. Any information identifying the victim by name, birth date, address or relation to the person } \\
\text { listed by the division shall be excluded by the division. } \\
\text { NY CoRRECT } § 168-q \text { (WEST 2008) } \\
\text { 1. } \\
\text { - The division shall maintain a subdirectory of level } 2 \text { and } 3 \text { sex offenders. } \\
\text { - The subdirectory shall have sex offender listings categorized by county and zip code. } \\
\text { - A copy of the subdirectory shall annually be distributed to the offices of local village, town, city, county or state } \\
\text { law enforcement agencies for purposes of public access. } \\
\text { - The subdirectory provided for herein shall be updated monthly to maintain its efficiency and usefulness and shall } \\
\text { be computer accessible. } \\
\text { - Such subdirectory shall be made available at all times on the internet via the division homepage. }\end{array}$ \\
\hline $\begin{array}{l}\text { Limitations on Residency or } \\
\text { Employment } \\
\text { (New York) }\end{array}$ & $\begin{array}{l}\text { NY CORRECT } § 168-v \text { (WEST 2008) } \\
\text { No registrant may operate, be employed on or dispense goods for sale at retail on a motor vehicle engaged in retail } \\
\text { sales of frozen desserts (i.e., ice cream trucks). }\end{array}$ \\
\hline
\end{tabular}

** Denotes those states where sex offender registration is required for convictions under the staff sexual misconduct laws of the states. Staff and 158 inmates could also be required to register as sex offenders if the offense were charged under other registrable offenses.

This publication is developed by the NIC/WCL Project on Addressing Prison Rape under NIC Cooperative Agreement 06S20GJJ1.

This is not to be posted or reproduced without permission from the authors.

American University, Washington College of Law

Current as of August 2009 


\section{Fifty State Survey of Adult Sex Offender Registration Requirements}

\section{NIC/WCL Project on Addressing Prison Rape}

\begin{tabular}{|c|c|}
\hline $\begin{array}{l}\text { Duration of Registration } \\
\text { (New York) }\end{array}$ & $\begin{array}{l}\text { NY CORRECT } § 168 \text {-h (WEST 2008) } \\
20 \text { years for offenders who have not been designated a sexual predator, sexually violent offender or predicate sex } \\
\text { offender and who are classified a level } 1 \text { offender. } \\
\text { Life for sexual predators, sexually violent offenders, or predicate sex offenders or offenders who are classified a } \\
\text { level } 2 \text { or } 3 \text { offender. } \\
\text { NY CORRECT } \S 168 \text {-o (WEST 2008) } \\
\text { Sex offenders who are classified at level 2, but who have not bee designated a sexual predator, sexually violent } \\
\text { offender or predicate sex offender may petition for termination of the registration obligation after } 30 \text { years. }\end{array}$ \\
\hline & NORTH CAROLINA** \\
\hline
\end{tabular}

** Denotes those states where sex offender registration is required for convictions under the staff sexual misconduct laws of the states. Staff and 159 inmates could also be required to register as sex offenders if the offense were charged under other registrable offenses.

This publication is developed by the NIC/WCL Project on Addressing Prison Rape under NIC Cooperative Agreement 06S20GJJ1.

This is not to be posted or reproduced without permission from the authors.

American University, Washington College of Law

Current as of August 2009 


\section{Fifty State Survey of Adult Sex Offender Registration Requirements}

\section{NIC/WCL Project on Addressing Prison Rape}

\begin{tabular}{|c|c|}
\hline $\begin{array}{l}\text { Registrable Offenses Cont'd } \\
\text { (North Carolina) }\end{array}$ & 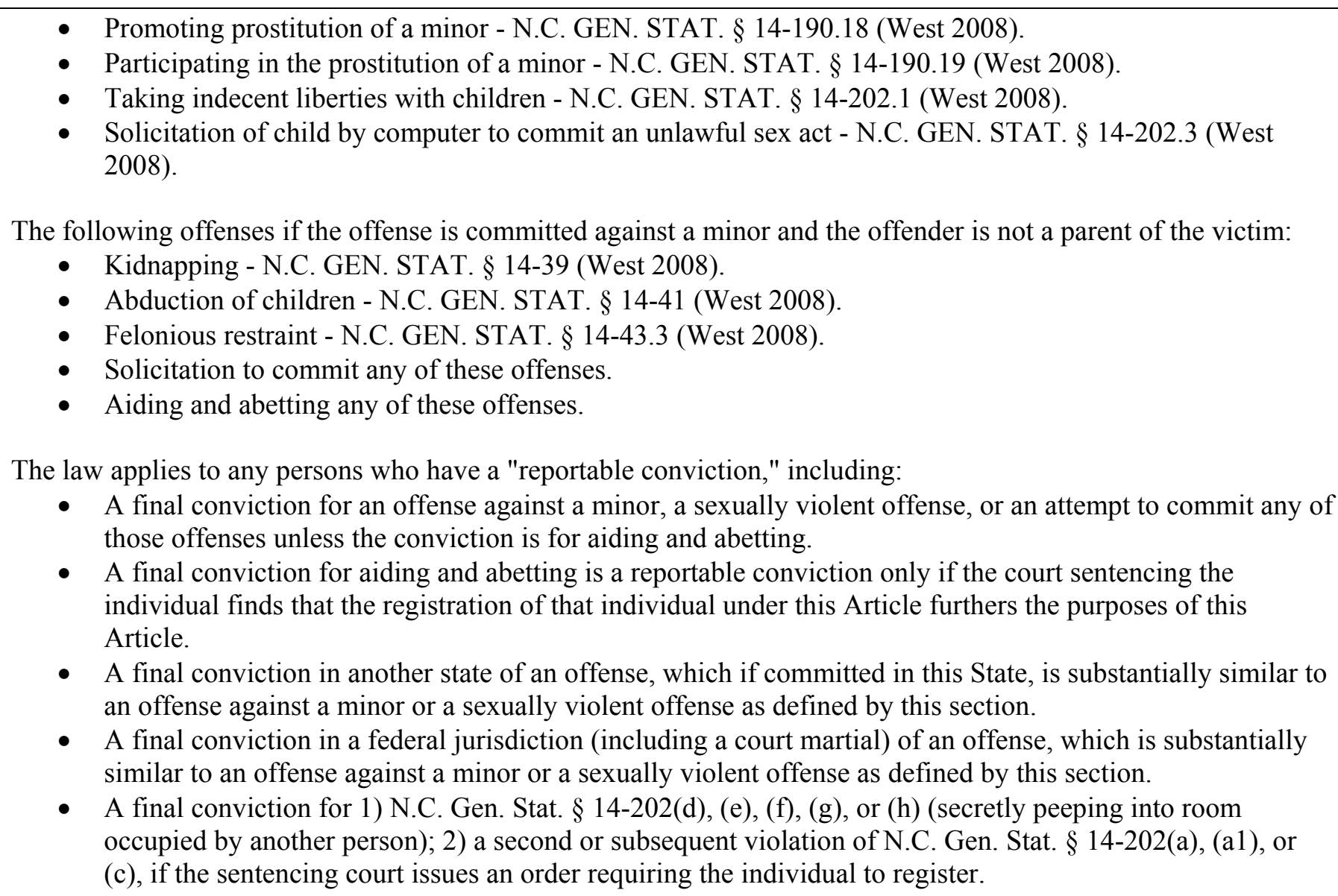 \\
\hline
\end{tabular}

** Denotes those states where sex offender registration is required for convictions under the staff sexual misconduct laws of the states. Staff and inmates could also be required to register as sex offenders if the offense were charged under other registrable offenses.

This publication is developed by the NIC/WCL Project on Addressing Prison Rape under NIC Cooperative Agreement 06S20GJJ1.

This is not to be posted or reproduced without permission from the authors.

American University, Washington College of Law

Current as of August 2009 


\section{Fifty State Survey of Adult Sex Offender Registration Requirements}

\section{NIC/WCL Project on Addressing Prison Rape}

\begin{tabular}{|c|c|}
\hline $\begin{array}{l}\text { Sex Offender Registration } \\
\text { Required for Staff Sexual } \\
\text { Misconduct? } \\
\text { (North Carolina) }\end{array}$ & $\begin{array}{l}\text { YES. } \\
\text { N.C.G.S.A. § 14-27.7 (West 2008) } \\
\text { - If a defendant who has assumed the position of a parent in the home of a minor victim engages in vaginal } \\
\text { intercourse or a sexual act with a victim who is a minor residing in the home, or if a person having custody } \\
\text { of a victim of any age or a person who is an agent or employee of any person, or institution, whether such } \\
\text { institution is private, charitable, or governmental, having custody of a victim of any age engages in vaginal } \\
\text { intercourse or a sexual act with such victim, the defendant is guilty of a Class E felony. Consent is not a } \\
\text { defense to a charge under this section. }\end{array}$ \\
\hline $\begin{array}{l}\text { Information Maintained in } \\
\text { Sex Offender Registry } \\
\text { (North Carolina) }\end{array}$ & $\begin{array}{l}\text { N.C.G.S.A. § 14-208.7 (West 2008) } \\
\text { (b) The Division shall provide each sheriff with forms for registering persons as required by this Article. The } \\
\text { registration form shall require: } \\
\text { (1) The person's full name, each alias, date of birth, sex, race, height, weight, eye color, hair color, drivers } \\
\text { license number, and home address; } \\
\text { (2) The type of offense for which the person was convicted, the date of conviction, and the sentence imposed; } \\
\text { (3) A current photograph; } \\
\text { (4) The person's fingerprints; } \\
\text { (5) A statement indicating whether the person is a student or expects to enroll as a student within a year of } \\
\text { registering. If the person is a student or expects to enroll as a student within a year of registration, then the } \\
\text { registration form shall also require the name and address of the educational institution at which the person } \\
\text { is a student or expects to enroll as a student; and } \\
\text { (6) A statement indicating whether the person is employed or expects to be employed at an institution of higher } \\
\text { education within a year of registering. If the person is employed or expects to be employed at an institution } \\
\text { of higher education within a year of registration, then the registration form shall also require the name and } \\
\text { address of the educational institution at which the person is or expects to be employed. }\end{array}$ \\
\hline
\end{tabular}

** Denotes those states where sex offender registration is required for convictions under the staff sexual misconduct laws of the states. Staff and 161 inmates could also be required to register as sex offenders if the offense were charged under other registrable offenses.

This publication is developed by the NIC/WCL Project on Addressing Prison Rape under NIC Cooperative Agreement 06S20GJJ1.

This is not to be posted or reproduced without permission from the authors.

American University, Washington College of Law

Current as of August 2009 


\section{Fifty State Survey of Adult Sex Offender Registration Requirements}

\section{NIC/WCL Project on Addressing Prison Rape}

\begin{tabular}{|c|c|}
\hline $\begin{array}{l}\text { Community Notification } \\
\text { and Websites } \\
\text { (North Carolina) }\end{array}$ & $\begin{array}{l}\text { N.C.G.S.A. } \S 14-208.10 \text { (West 2008) } \\
\text { (a): } \\
\text {-Information regarding a person required to register under this Article is public record and shall be available for } \\
\text { public inspection. } \\
\text { - The sheriff shall release any other relevant information that is necessary to protect the public concerning a } \\
\text { specific person, but shall not release the identity of the victim of the offense that required registration under this } \\
\text { Article. } \\
\text { (b) Any person may obtain a copy of an individual's registration form, a part of the county registry, or all of the } \\
\text { county registry, by submitting a written request for the information to the sheriff. } \\
\text { N.C.G.S.A. } \S 14-208.15 \text { (West } 2008 \text { ) } \\
\text { (b): } \\
\text { - The Division shall provide free public access to automated data from the statewide registry, including } \\
\text { photographs provided by the registering sheriffs, via the Internet. } \\
\text { - The public will be able to access the statewide registry to view an individual registration record, a part of the } \\
\text { statewide registry, or all of the statewide registry. } \\
\text { - The Division may also provide copies of registry information to the public upon written request and may charge } \\
\text { a reasonable fee for duplicating costs and mailings costs. }\end{array}$ \\
\hline $\begin{array}{l}\text { Limitations on Residency or } \\
\text { Employment } \\
\text { (North Carolina) }\end{array}$ & None \\
\hline $\begin{array}{l}\text { Duration of Registration } \\
\text { (North Carolina) }\end{array}$ & $\begin{array}{l}\text { N.C.G.S.A. } \$ 14-208.7 \text { (West 2008) } \\
\text { (a) } 10 \text { years for persons not subject to lifetime registration. }\end{array}$ \\
\hline
\end{tabular}

** Denotes those states where sex offender registration is required for convictions under the staff sexual misconduct laws of the states. Staff and 162 inmates could also be required to register as sex offenders if the offense were charged under other registrable offenses.

This publication is developed by the NIC/WCL Project on Addressing Prison Rape under NIC Cooperative Agreement 06S20GJJ1.

This is not to be posted or reproduced without permission from the authors.

American University, Washington College of Law

Current as of August 2009 


\section{Fifty State Survey of Adult Sex Offender Registration Requirements}

\section{NIC/WCL Project on Addressing Prison Rape}

\begin{tabular}{|c|c|}
\hline $\begin{array}{l}\text { Duration of Registration } \\
\text { Cont'd } \\
\text { (North Carolina) }\end{array}$ & $\begin{array}{l}\text { N.C. GEN. STAT. } \$ 14-208.23 \text { (West 2008) } \\
\text { Life for recidivists, persons convicted of an aggravated offense and those who are classified as a sexually violent } \\
\text { predator. }\end{array}$ \\
\hline & NORTH DAKOTA** \\
\hline
\end{tabular}

** Denotes those states where sex offender registration is required for convictions under the staff sexual misconduct laws of the states. Staff and 163 inmates could also be required to register as sex offenders if the offense were charged under other registrable offenses.

This publication is developed by the NIC/WCL Project on Addressing Prison Rape under NIC Cooperative Agreement 06S20GJJ1.

This is not to be posted or reproduced without permission from the authors.

American University, Washington College of Law

Current as of August 2009 


\section{Fifty State Survey of Adult Sex Offender Registration Requirements}

\section{NIC/WCL Project on Addressing Prison Rape}

\begin{tabular}{|c|c|}
\hline $\begin{array}{l}\text { Registrable Offenses Cont'd } \\
\text { (North Dakota) }\end{array}$ & 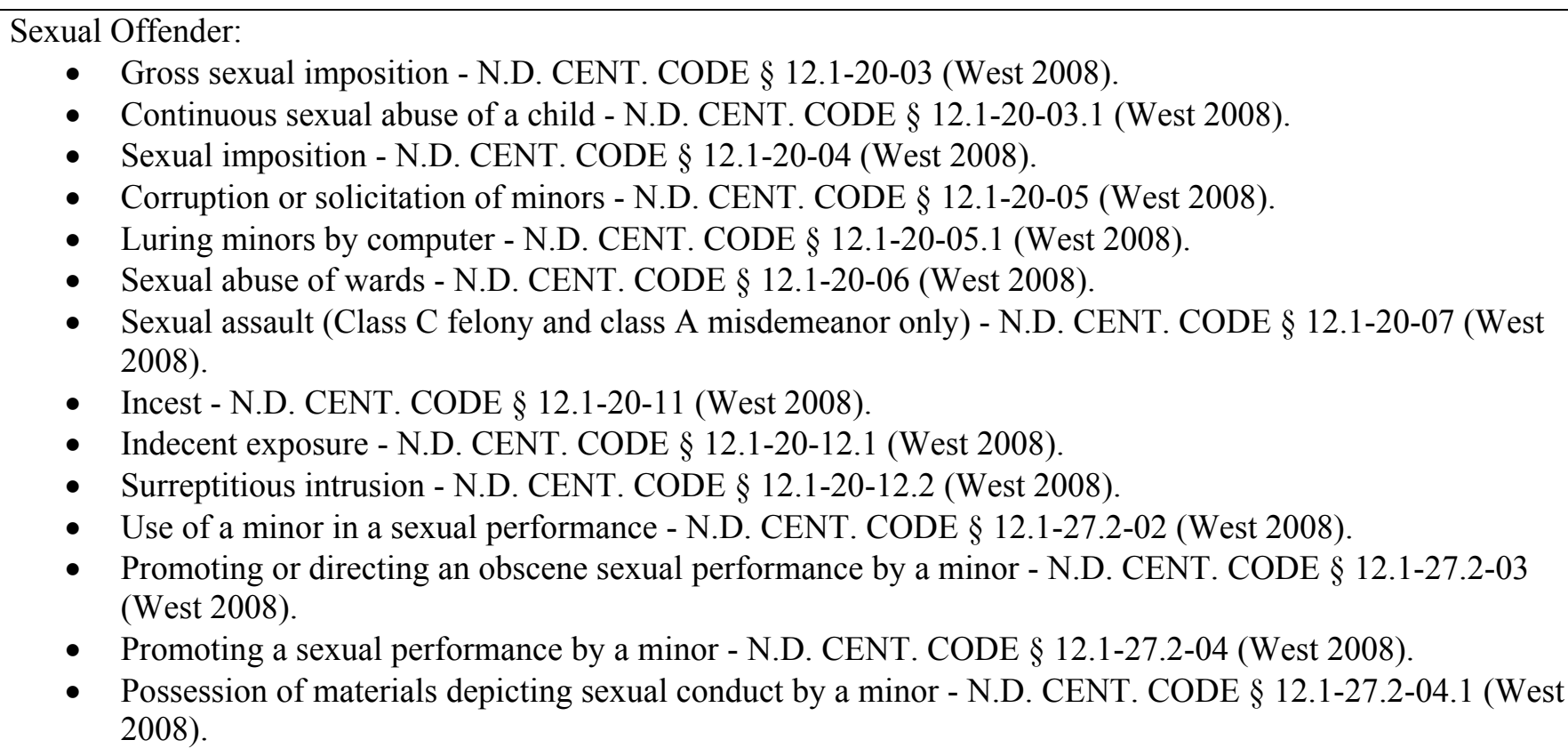 \\
\hline
\end{tabular}

** Denotes those states where sex offender registration is required for convictions under the staff sexual misconduct laws of the states. Staff and 164 inmates could also be required to register as sex offenders if the offense were charged under other registrable offenses.

This publication is developed by the NIC/WCL Project on Addressing Prison Rape under NIC Cooperative Agreement 06S20GJJ1.

This is not to be posted or reproduced without permission from the authors.

American University, Washington College of Law

Current as of August 2009 


\section{Fifty State Survey of Adult Sex Offender Registration Requirements}

\section{NIC/WCL Project on Addressing Prison Rape}

\begin{tabular}{|c|c|}
\hline $\begin{array}{l}\text { Sex Offender Registration } \\
\text { Required for Staff Sexual } \\
\text { Misconduct? Cont'd } \\
\text { (North Dakota) }\end{array}$ & $\begin{array}{l}\text { 1. A person who knowingly has sexual contact with another person, or who causes another person to have sexual } \\
\text { contact with that person, is guilty of an offense if: } \\
\text { d. The other person is in official custody or detained in a hospital, prison, or other institution and the actor has } \\
\text { supervisory or disciplinary authority over that other person }\end{array}$ \\
\hline $\begin{array}{l}\text { Information Maintained in } \\
\text { Sex Offender Registry } \\
\text { (North Dakota) }\end{array}$ & $\begin{array}{l}\text { N.D.C.C. } \$ 12.1-32-15 \text { (West 2008). } \\
\text { (7) } \\
\text { - statement signed by offender } \\
\text { - fingerprints } \\
\text { - photograph } \\
\text { - blood and fluid samples } \\
\text { - place of residence, school and/or employment }\end{array}$ \\
\hline $\begin{array}{l}\text { Community Notification } \\
\text { and Websites } \\
\text { (North Dakota) }\end{array}$ & $\begin{array}{l}\text { N.D.C.C. } \$ 12.1-32-15 \text { (West 2008). } \\
\text { 13. } \\
\text { - Relevant and necessary conviction and registration information must be disclosed to the public by a law } \\
\text { enforcement agency if the individual is a moderate or high risk and the agency determines that disclosure of the } \\
\text { conviction and registration information is necessary for public protection. } \\
\text { - The attorney general shall develop guidelines for public disclosure of offender registration information. } \\
\text { - Public disclosure may include internet access if the offender: } \\
\text { o is required to register for a lifetime under subsection } 8 \text {; } \\
\text { o has been determined to be a high risk to the public by the department, the attorney general, or the courts, } \\
\text { according to guidelines developed by those agencies; or } \\
\text { o has been determined to be a high risk to the public by an agency of another state or the federal government. } \\
\text { - If the offender has been determined to be a moderate risk, public disclosure must include, at a minimum, }\end{array}$ \\
\hline
\end{tabular}

** Denotes those states where sex offender registration is required for convictions under the staff sexual misconduct laws of the states. Staff and 165 inmates could also be required to register as sex offenders if the offense were charged under other registrable offenses.

This publication is developed by the NIC/WCL Project on Addressing Prison Rape under NIC Cooperative Agreement 06S20GJJ1.

This is not to be posted or reproduced without permission from the authors.

American University, Washington College of Law

Current as of August 2009 


\section{Fifty State Survey of Adult Sex Offender Registration Requirements}

\section{NIC/WCL Project on Addressing Prison Rape}

\begin{tabular}{|c|c|}
\hline $\begin{array}{l}\text { Community Notification } \\
\text { and Websites } \\
\text { (North Dakota) }\end{array}$ & $\begin{array}{l}\text { notification to the victim of the offense and to any agency, civic organization, or group of persons who have } \\
\text { characteristics similar to those of a victim of the offender. } \\
\text { - Upon request, law enforcement agencies may release conviction and registration information regarding low-risk, } \\
\text { moderate-risk, or high-risk offenders }\end{array}$ \\
\hline $\begin{array}{l}\text { Limitations on Residency or } \\
\text { Employment } \\
\text { (North Dakota) }\end{array}$ & None. \\
\hline \multicolumn{2}{|r|}{ OHIO** } \\
\hline $\begin{array}{l}\text { Registrable Offenses } \\
\text { (Ohio) }\end{array}$ & 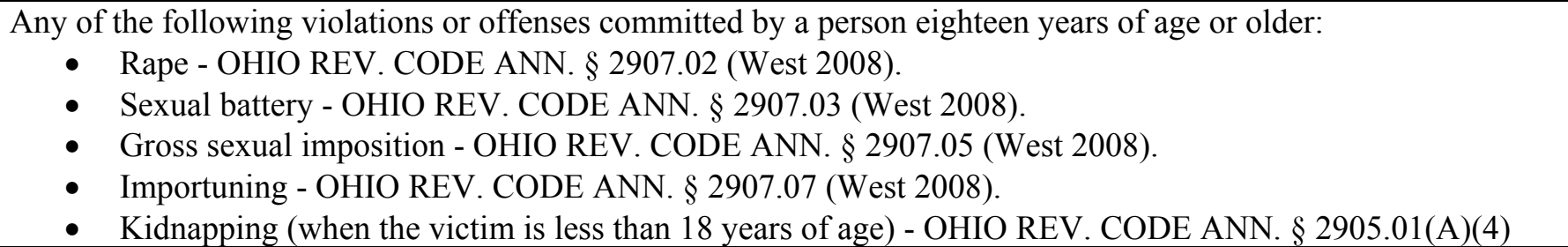 \\
\hline
\end{tabular}

** Denotes those states where sex offender registration is required for convictions under the staff sexual misconduct laws of the states. Staff and 166 inmates could also be required to register as sex offenders if the offense were charged under other registrable offenses.

This publication is developed by the NIC/WCL Project on Addressing Prison Rape under NIC Cooperative Agreement 06S20GJJ1.

This is not to be posted or reproduced without permission from the authors.

American University, Washington College of Law

Current as of August 2009 


\section{Fifty State Survey of Adult Sex Offender Registration Requirements}

\section{NIC/WCL Project on Addressing Prison Rape}

\begin{tabular}{|c|c|}
\hline $\begin{array}{l}\text { Registrable Offenses Cont'd } \\
\text { (Ohio) }\end{array}$ & 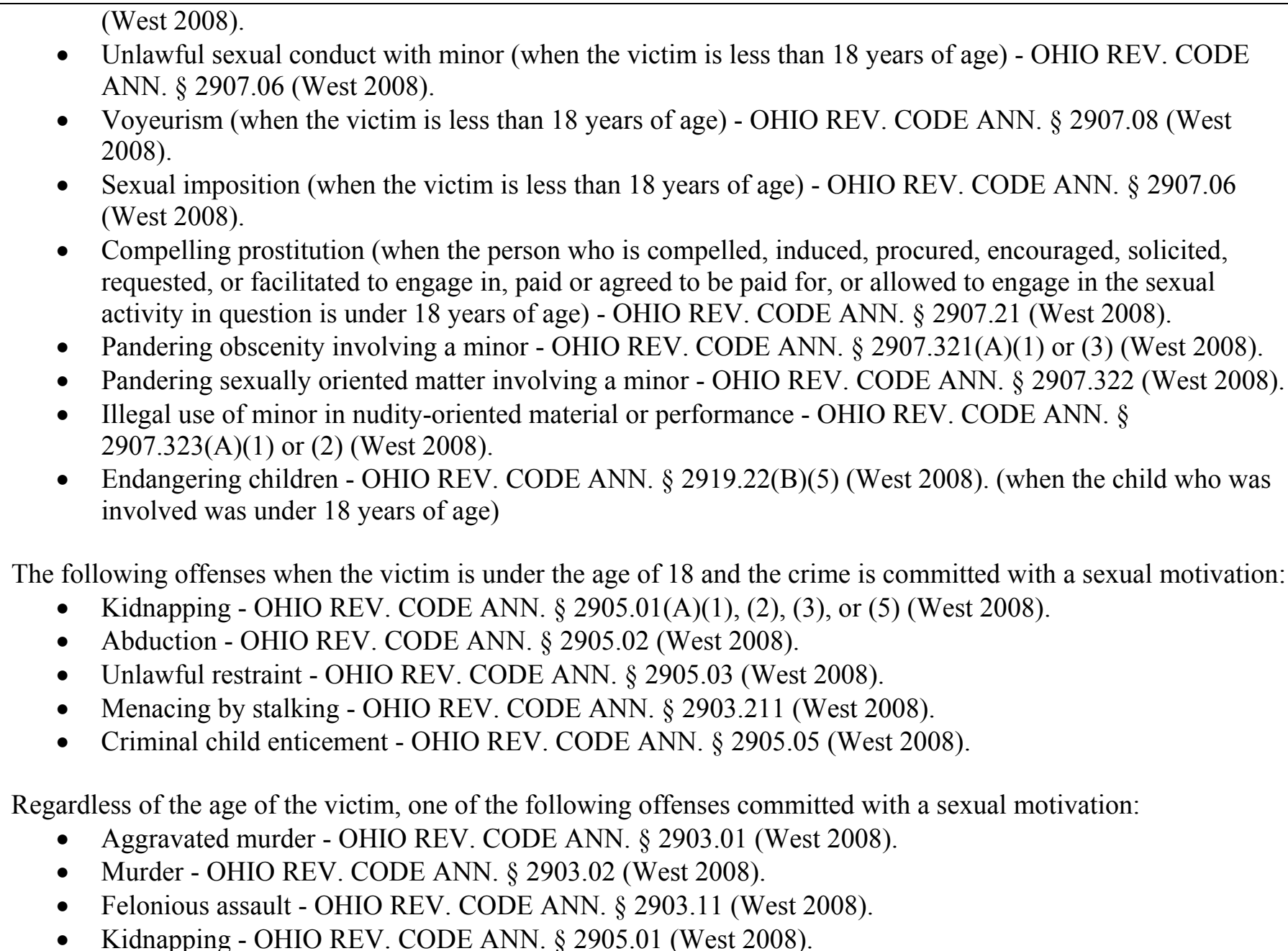 \\
\hline
\end{tabular}

** Denotes those states where sex offender registration is required for convictions under the staff sexual misconduct laws of the states. Staff and 167 inmates could also be required to register as sex offenders if the offense were charged under other registrable offenses.

This publication is developed by the NIC/WCL Project on Addressing Prison Rape under NIC Cooperative Agreement 06S20GJJ1.

This is not to be posted or reproduced without permission from the authors.

American University, Washington College of Law

Current as of August 2009 


\section{Fifty State Survey of Adult Sex Offender Registration Requirements}

\section{NIC/WCL Project on Addressing Prison Rape}

Registrable Offenses Cont'd (Ohio)

- Involuntary manslaughter - OHIO REV. CODE ANN. § 2903.04(A) (West 2008).

A violent sex offense, or a designated homicide, assault, or kidnapping offense if the offender also was convicted of or pleaded guilty to a sexual motivation specification that was included in the indictment, count in the indictment, or information charging the designated homicide, assault, or kidnapping offense:

- Violent sex offense - Rape, sexual battery or gross sexual imposition with a person less than 13 years of age. Also includes a felony violation of another state or the United States that is substantially equivalent to one of these crimes or the attempt or complicity to commit these crimes if it is a felony.

- Designated homicide, assault or kidnapping offense - Aggravated murder, murder, felonious assault, kidnapping or involuntary manslaughter (unlawful termination of another's pregnancy as a proximate result of the offender's committing or attempting to commit a felony). Also, the attempt or complicity to commit these crimes if it is a felony.

When the victim of the offense is 18 years of age or older:

- Sexual imposition - OHIO REV. CODE ANN. § 2907.06 (West 2008).

- Voyeurism - OHIO REV. CODE ANN. § 2907.08 (West 2008).

- Menacing by stalking (when the offense is committed with a sexual motivation) - OHIO REV. CODE ANN. § 2903.211 (West 2008).

- A violation of any former law of this state, any existing or former municipal ordinance or law of another state or the United States, any existing or former law applicable in a military court or in an Indian tribal court, or any existing or former law of any nation other than the United States, that is or was substantially equivalent to any offense listed above.

- An attempt to commit, conspiracy to commit, or complicity in committing any offense listed above.

An act committed by a person under eighteen years of age that is any of the following:

Subject to division (D)(2)(i) (child's case transferred for criminal prosecution), regardless of the age of the victim of the violation, a violation of:

- $\quad$ Rape - OHIO REV. CODE ANN. § 2907.02 (West 2008).

** Denotes those states where sex offender registration is required for convictions under the staff sexual misconduct laws of the states. Staff and 168 inmates could also be required to register as sex offenders if the offense were charged under other registrable offenses.

This publication is developed by the NIC/WCL Project on Addressing Prison Rape under NIC Cooperative Agreement 06S20GJJ1.

This is not to be posted or reproduced without permission from the authors.

American University, Washington College of Law

Current as of August 2009 


\section{Fifty State Survey of Adult Sex Offender Registration Requirements}

\section{NIC/WCL Project on Addressing Prison Rape}

\begin{tabular}{|c|c|}
\hline $\begin{array}{l}\text { Registrable Offenses Cont'd } \\
\text { (Ohio) }\end{array}$ & 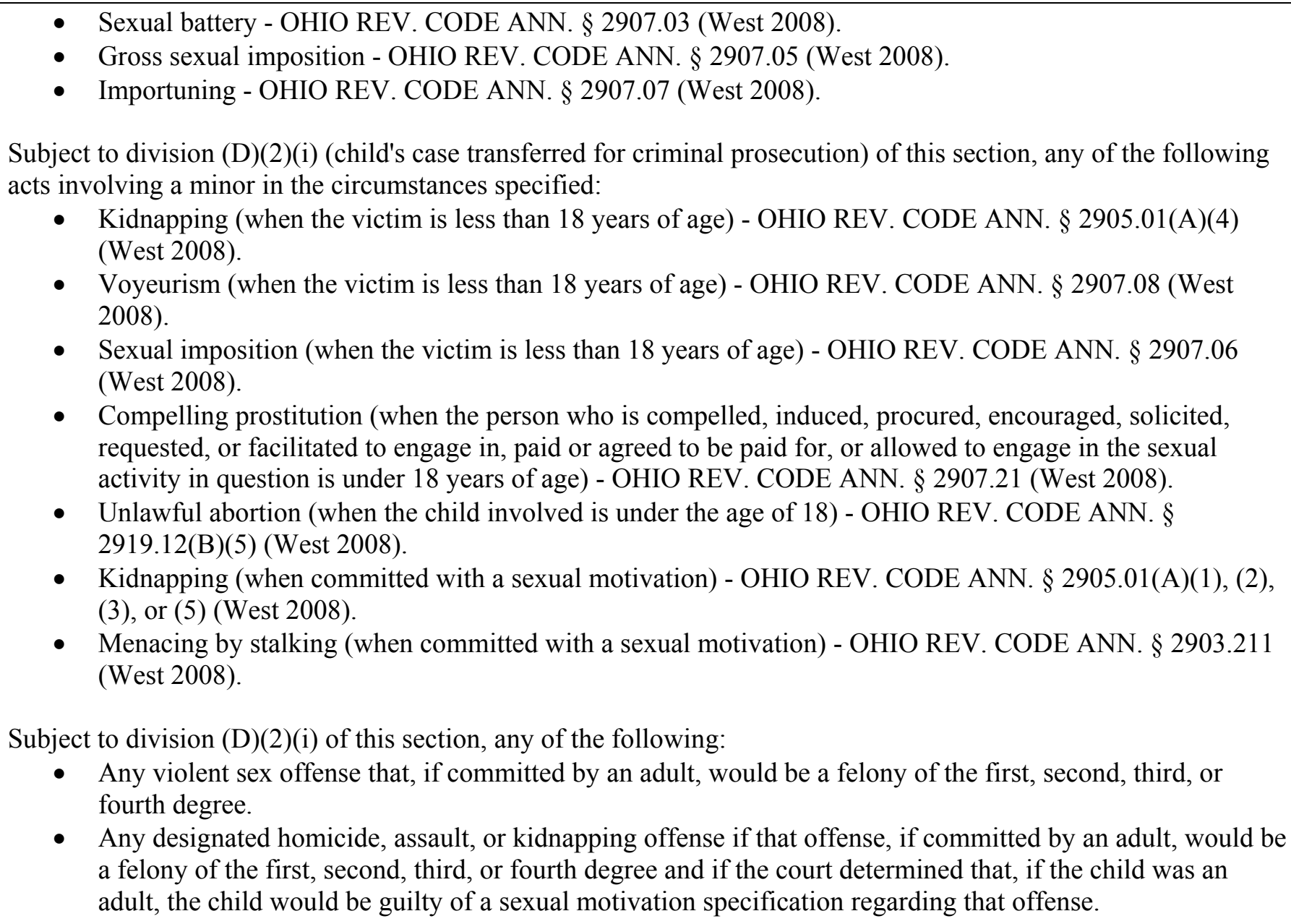 \\
\hline
\end{tabular}

** Denotes those states where sex offender registration is required for convictions under the staff sexual misconduct laws of the states. Staff and inmates could also be required to register as sex offenders if the offense were charged under other registrable offenses.

This publication is developed by the NIC/WCL Project on Addressing Prison Rape under NIC Cooperative Agreement 06S20GJJ1.

This is not to be posted or reproduced without permission from the authors.

American University, Washington College of Law

Current as of August 2009 


\section{Fifty State Survey of Adult Sex Offender Registration Requirements}

\section{NIC/WCL Project on Addressing Prison Rape}

\begin{tabular}{|c|c|}
\hline $\begin{array}{l}\text { Registrable Offenses Cont'd } \\
\text { (Ohio) }\end{array}$ & 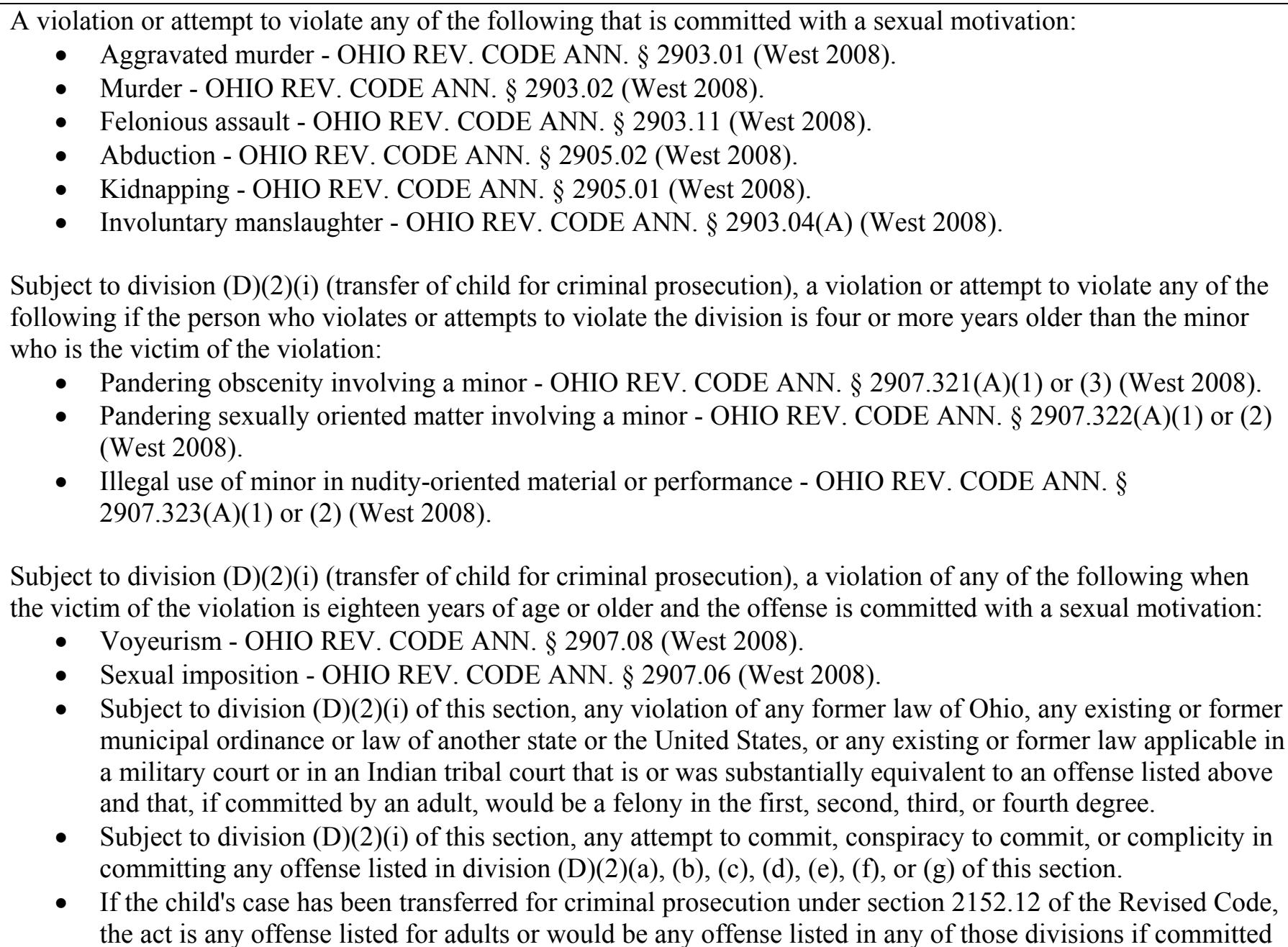 \\
\hline
\end{tabular}

** Denotes those states where sex offender registration is required for convictions under the staff sexual misconduct laws of the states. Staff and 170 inmates could also be required to register as sex offenders if the offense were charged under other registrable offenses.

This publication is developed by the NIC/WCL Project on Addressing Prison Rape under NIC Cooperative Agreement 06S20GJJ1.

This is not to be posted or reproduced without permission from the authors.

American University, Washington College of Law

Current as of August 2009 


\section{Fifty State Survey of Adult Sex Offender Registration Requirements}

\section{NIC/WCL Project on Addressing Prison Rape}

\begin{tabular}{|c|c|}
\hline $\begin{array}{l}\text { Registrable Offenses Cont'd } \\
\text { (Ohio) }\end{array}$ & by an adult. \\
\hline $\begin{array}{l}\text { Sex Offender Registration } \\
\text { Required for Staff Sexual } \\
\text { Misconduct? } \\
\text { (Ohio) }\end{array}$ & $\begin{array}{l}\text { YES. } \\
\text { R.C. } \$ 2907.03 \text { (West 2008) } \\
\text { (A) No person shall engage in sexual conduct with another, not the spouse of the offender, when any of the } \\
\text { following apply: } \\
\quad \text { (6) The other person is in custody of law or a patient in a hospital or other institution, and the offender has } \\
\quad \text { supervisory or disciplinary authority over the other person. }\end{array}$ \\
\hline $\begin{array}{l}\text { Information Maintained in } \\
\text { Sex Offender Registry } \\
\text { (Ohio) }\end{array}$ & $\begin{array}{l}\text { R.C. } \$ 2950.04 \text { (West 2008) } \\
\text { (C) The registration form to be used under divisions (A) and (B) of this section shall include or contain all of the } \\
\text { following for the offender or delinquent child who is registering: } \\
\text { (1) The offender's or delinquent child's name and any aliases used by the offender or delinquent child; } \\
\text { (2) The offender's or delinquent child's social security number and date of birth, including any alternate social } \\
\text { security numbers or dates of birth that the offender or delinquent child has used or uses; } \\
\text { (3) Regarding an offender or delinquent child who is registering under a duty imposed under division (A)(1) of } \\
\text { this section, a statement that the offender is serving a prison term, term of imprisonment, or any other type } \\
\text { of confinement or a statement that the delinquent child is in the custody of the department of youth } \\
\text { services or is confined in a secure facility that is not operated by the department; } \\
\text { (4) Regarding an offender or delinquent child who is registering under a duty imposed under division (A)(2), } \\
\text { (3), or (4) of this section as a result of the offender or delinquent child residing in this state or temporarily } \\
\text { being domiciled in this state for more than three days, the current residence address of the offender or } \\
\text { delinquent child who is registering, the name and address of the offender's or delinquent child's employer }\end{array}$ \\
\hline
\end{tabular}

** Denotes those states where sex offender registration is required for convictions under the staff sexual misconduct laws of the states. Staff and 171 inmates could also be required to register as sex offenders if the offense were charged under other registrable offenses.

This publication is developed by the NIC/WCL Project on Addressing Prison Rape under NIC Cooperative Agreement 06S20GJJ1.

This is not to be posted or reproduced without permission from the authors.

American University, Washington College of Law

Current as of August 2009 


\section{Fifty State Survey of Adult Sex Offender Registration Requirements}

\section{NIC/WCL Project on Addressing Prison Rape}

\begin{tabular}{|c|c|}
\hline $\begin{array}{l}\text { Information Maintained in } \\
\text { Sex Offender Registry } \\
\text { Cont'd } \\
\text { (Ohio) }\end{array}$ & 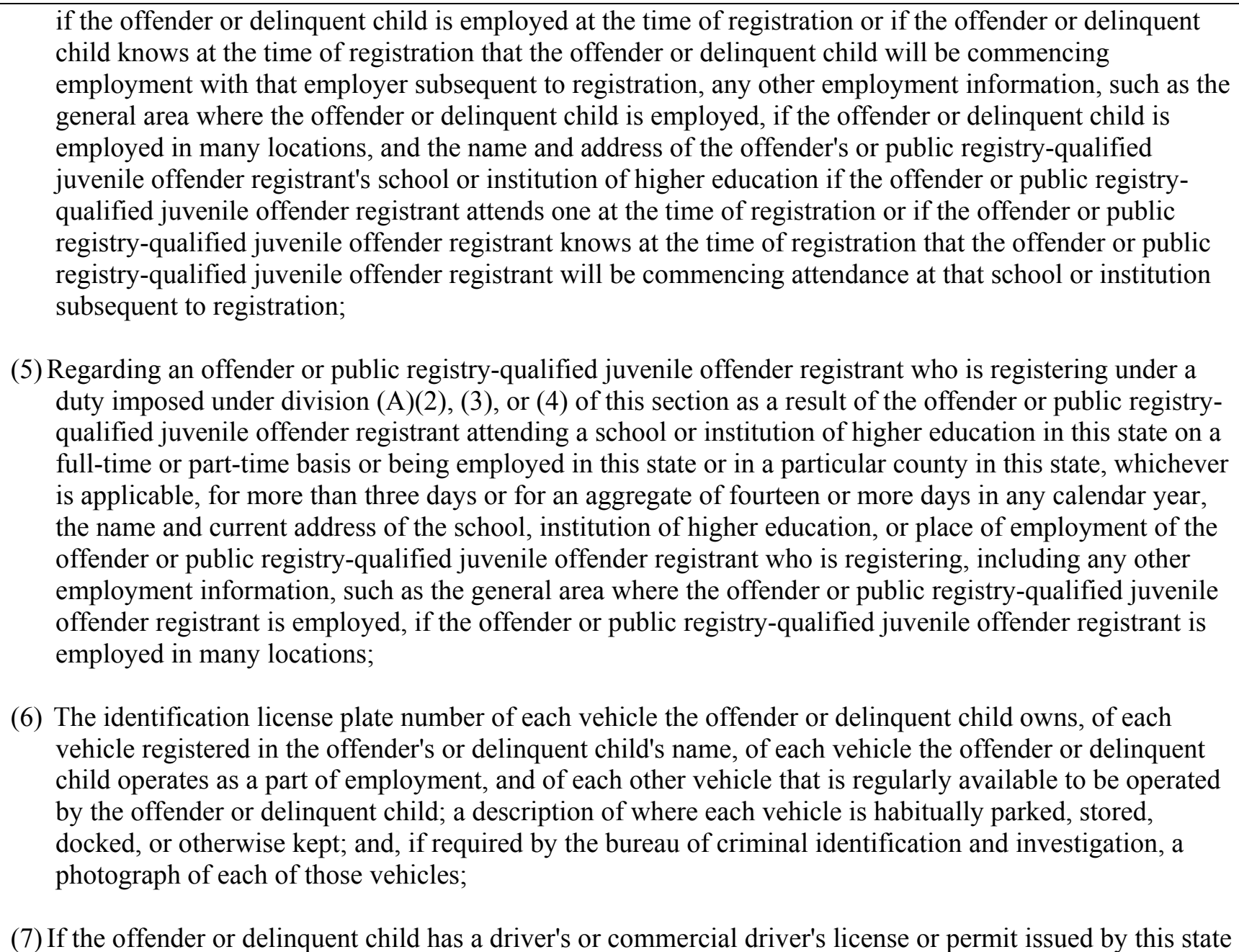 \\
\hline
\end{tabular}

** Denotes those states where sex offender registration is required for convictions under the staff sexual misconduct laws of the states. Staff and inmates could also be required to register as sex offenders if the offense were charged under other registrable offenses.

This publication is developed by the NIC/WCL Project on Addressing Prison Rape under NIC Cooperative Agreement 06S20GJJ1.

This is not to be posted or reproduced without permission from the authors.

American University, Washington College of Law

Current as of August 2009 


\section{Fifty State Survey of Adult Sex Offender Registration Requirements}

\section{NIC/WCL Project on Addressing Prison Rape}

\begin{tabular}{|c|c|}
\hline $\begin{array}{l}\text { Information Maintained in } \\
\text { Sex Offender Registry } \\
\text { Cont'd } \\
\text { (Ohio) }\end{array}$ & $\begin{array}{l}\text { or any other state or a state identification card issued under section } 4507.50 \text { or } 4507.51 \text { of the Revised } \\
\text { Code or a comparable identification card issued by another state, the driver's license number, commercial } \\
\text { driver's license number, or state identification card number; } \\
\text { (8) If the offender or delinquent child was convicted of, pleaded guilty to, or was adjudicated a delinquent } \\
\text { child for committing the sexually oriented offense resulting in the registration duty in a court in another } \\
\text { state, in a federal court, military court, or Indian tribal court, or in a court in any nation other than the } \\
\text { United States, a DNA specimen, as defined in section } 109.573 \text { of the Revised Code, from the offender or } \\
\text { delinquent child, a citation for, and the name of, the sexually oriented offense resulting in the registration } \\
\text { duty, and a certified copy of a document that describes the text of that sexually oriented offense; } \\
\text { (9) A description of each professional and occupational license, permit, or registration, including those } \\
\text { licenses, permits, and registrations issued under Title XLVII of the Revised Code, held by the offender or } \\
\text { delinquent child; } \\
\text { (10) Any email addresses, internet identifiers, or telephone numbers registered to or used by the offender or } \\
\text { delinquent child; }\end{array}$ \\
\hline $\begin{array}{l}\text { Community Notification } \\
\text { and Websites } \\
\text { (Ohio) }\end{array}$ & $\begin{array}{l}\text { R.C. } \$ 2950.11 \text { (West 2008) } \\
\text { The sheriff shall provide the notice to all of the following persons: } \\
\text { (1) } \\
\text { (a) Any occupant of each residential unit that is located within one thousand feet of the offender's or delinquent } \\
\text { child's residential premises, that is located within the county served by the sheriff, and that is not located in } \\
\text { a multi-unit building. } \\
\text { (b) If the offender or delinquent child resides in a multi-unit building, any occupant of each residential unit that } \\
\text { is located in that multi-unit building and that shares a common hallway with the offender or delinquent }\end{array}$ \\
\hline
\end{tabular}

** Denotes those states where sex offender registration is required for convictions under the staff sexual misconduct laws of the states. Staff and inmates could also be required to register as sex offenders if the offense were charged under other registrable offenses.

This publication is developed by the NIC/WCL Project on Addressing Prison Rape under NIC Cooperative Agreement 06S20GJJ1.

This is not to be posted or reproduced without permission from the authors.

American University, Washington College of Law

Current as of August 2009 


\section{Fifty State Survey of Adult Sex Offender Registration Requirements}

\section{NIC/WCL Project on Addressing Prison Rape}

\begin{tabular}{|c|c|}
\hline $\begin{array}{l}\text { Community Notification } \\
\text { and Websites Cont'd } \\
(\text { Ohio) }\end{array}$ & 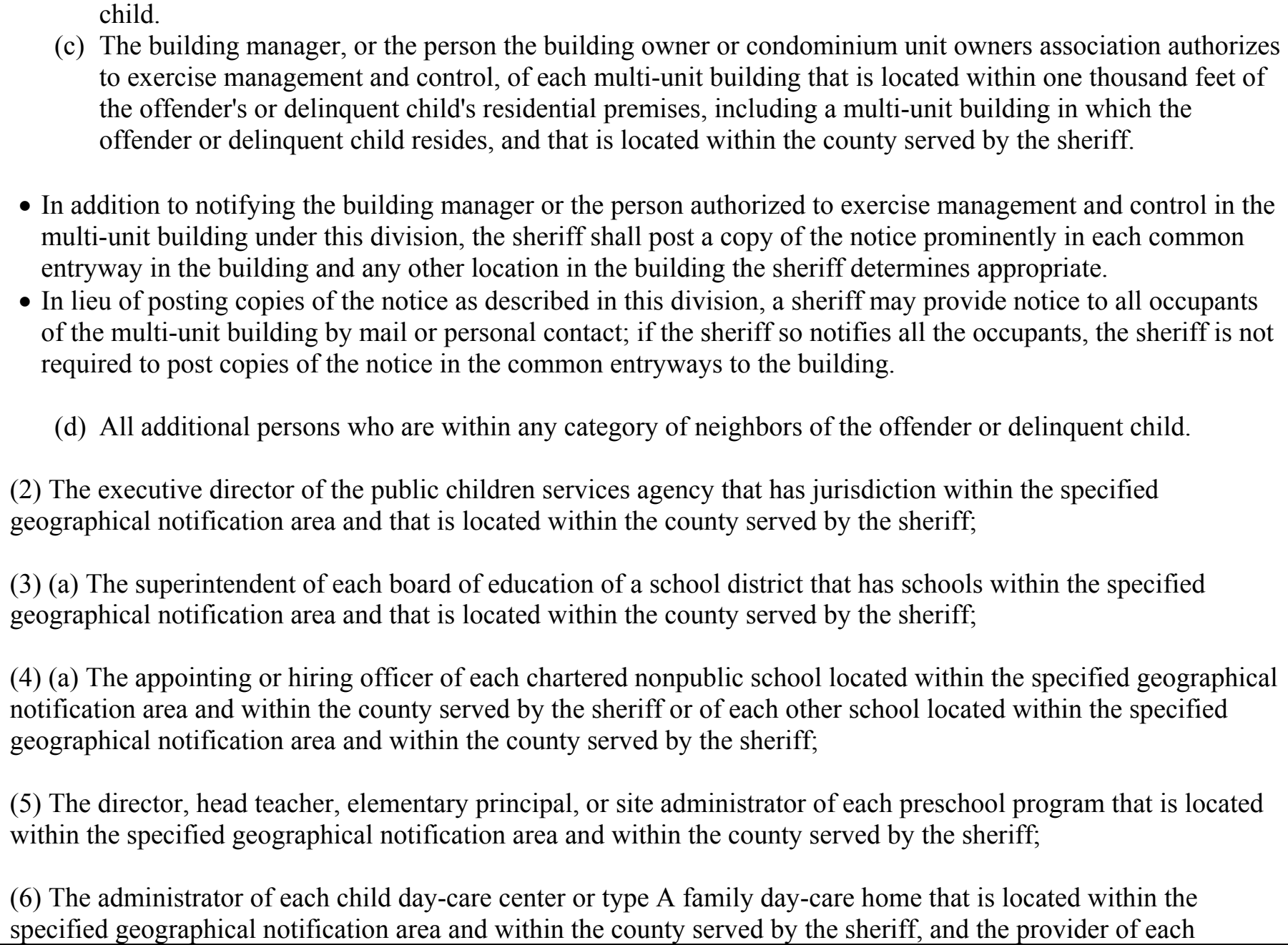 \\
\hline
\end{tabular}

** Denotes those states where sex offender registration is required for convictions under the staff sexual misconduct laws of the states. Staff and inmates could also be required to register as sex offenders if the offense were charged under other registrable offenses.

This publication is developed by the NIC/WCL Project on Addressing Prison Rape under NIC Cooperative Agreement 06S20GJJ1.

This is not to be posted or reproduced without permission from the authors.

American University, Washington College of Law

Current as of August 2009 


\section{Fifty State Survey of Adult Sex Offender Registration Requirements}

\section{NIC/WCL Project on Addressing Prison Rape}

\begin{tabular}{|c|c|}
\hline $\begin{array}{l}\text { Community Notification } \\
\text { and Websites Cont'd } \\
(\text { Ohio) }\end{array}$ & 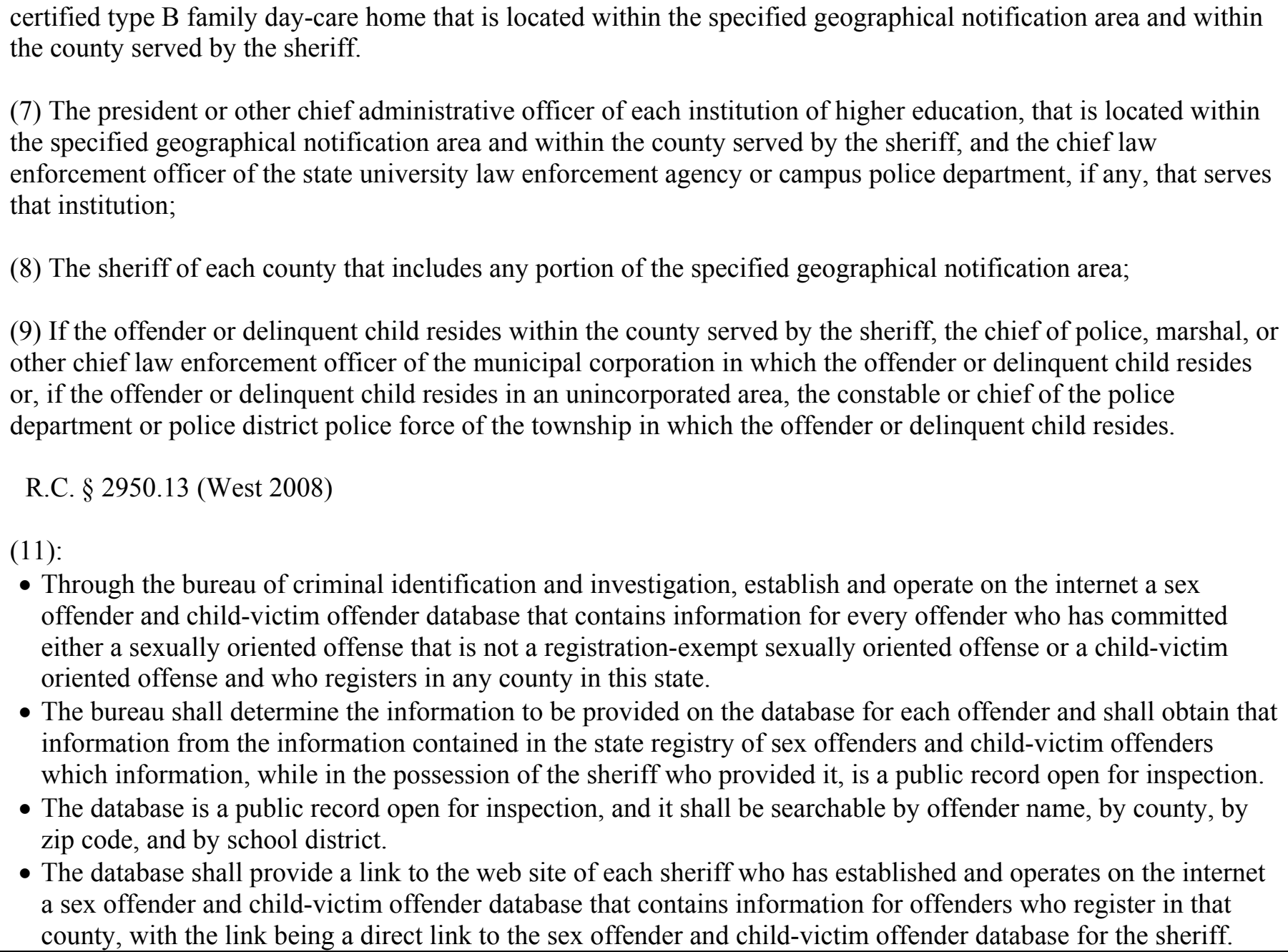 \\
\hline
\end{tabular}

** Denotes those states where sex offender registration is required for convictions under the staff sexual misconduct laws of the states. Staff and inmates could also be required to register as sex offenders if the offense were charged under other registrable offenses.

This publication is developed by the NIC/WCL Project on Addressing Prison Rape under NIC Cooperative Agreement 06S20GJJ1.

This is not to be posted or reproduced without permission from the authors.

American University, Washington College of Law

Current as of August 2009 


\section{Fifty State Survey of Adult Sex Offender Registration Requirements}

\section{NIC/WCL Project on Addressing Prison Rape}

\begin{tabular}{|c|c|}
\hline $\begin{array}{l}\text { Limitations on Residency or } \\
\text { Employment } \\
\text { (Ohio) }\end{array}$ & $\begin{array}{l}\text { R.C. } \S 2950.031 \text { (West } 2008 \text { ) } \\
\text { - Registrants may not establish residence or occupy residential premises within } 1000 \text { feet of any school. }\end{array}$ \\
\hline & OKLAHOMA** \\
\hline
\end{tabular}

** Denotes those states where sex offender registration is required for convictions under the staff sexual misconduct laws of the states. Staff and 176 inmates could also be required to register as sex offenders if the offense were charged under other registrable offenses.

This publication is developed by the NIC/WCL Project on Addressing Prison Rape under NIC Cooperative Agreement 06S20GJJ1.

This is not to be posted or reproduced without permission from the authors.

American University, Washington College of Law

Current as of August 2009 


\section{Fifty State Survey of Adult Sex Offender Registration Requirements}

\section{NIC/WCL Project on Addressing Prison Rape}

\begin{tabular}{|c|c|}
\hline $\begin{array}{l}\text { Registrable Offenses Cont'd } \\
\text { (Oklahoma) }\end{array}$ & 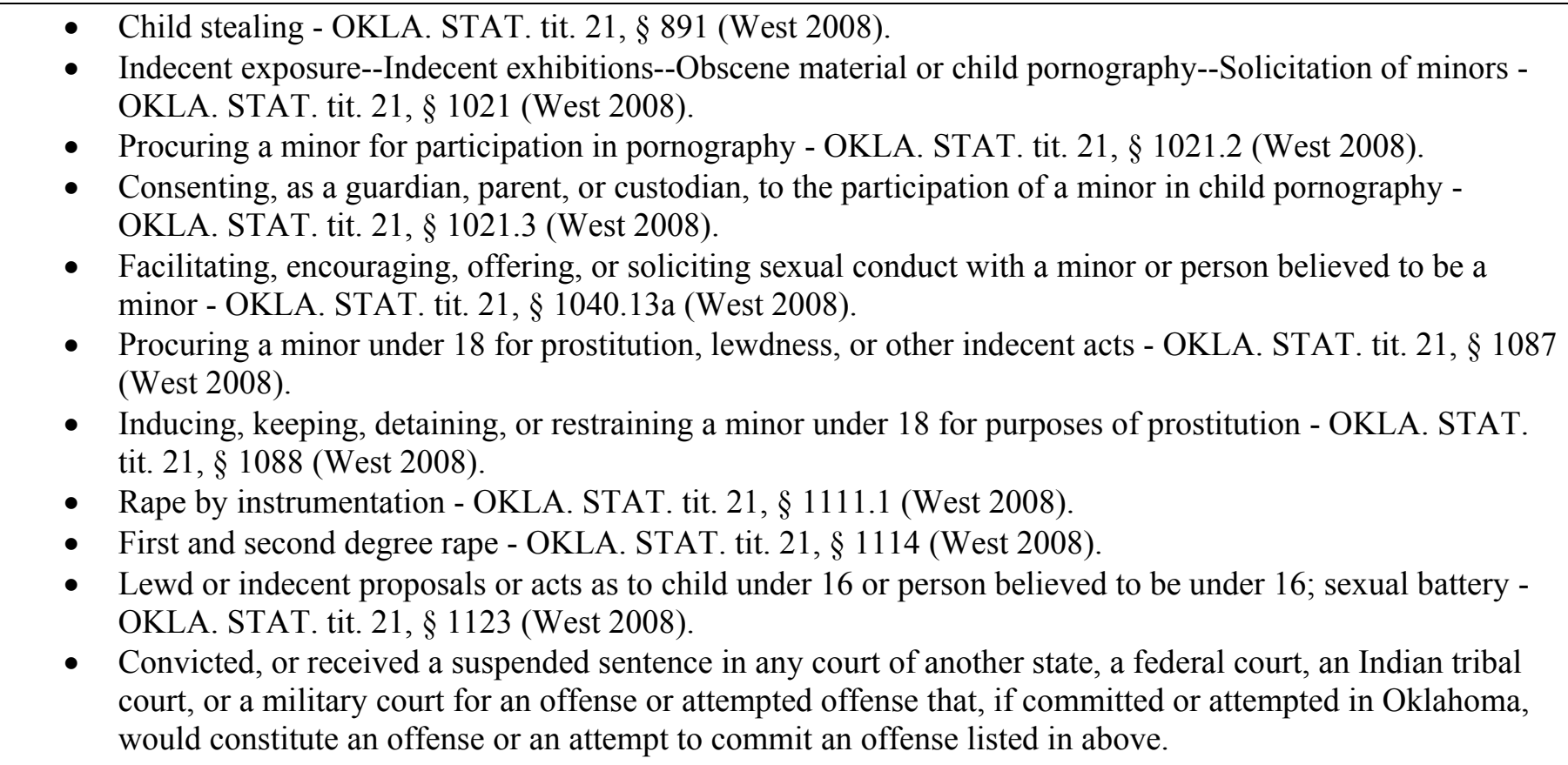 \\
\hline
\end{tabular}

** Denotes those states where sex offender registration is required for convictions under the staff sexual misconduct laws of the states. Staff and inmates could also be required to register as sex offenders if the offense were charged under other registrable offenses.

This publication is developed by the NIC/WCL Project on Addressing Prison Rape under NIC Cooperative Agreement 06S20GJJ1.

This is not to be posted or reproduced without permission from the authors.

American University, Washington College of Law

Current as of August 2009 


\section{Fifty State Survey of Adult Sex Offender Registration Requirements}

\section{NIC/WCL Project on Addressing Prison Rape}

\begin{tabular}{|c|c|}
\hline $\begin{array}{l}\text { Sex Offender Registration } \\
\text { Required for Staff Sexual } \\
\text { Misconduct? Cont'd } \\
\text { (Oklahoma) }\end{array}$ & $\begin{array}{l}\text { 2. rape committed upon a person incapable through mental illness or any unsoundness of mind of giving } \\
\text { legal consent regardless of the age of the person committing the crime; or } \\
\text { 3. rape accomplished where the victim is intoxicated by a narcotic or anesthetic agent, administered by or } \\
\text { with the privity of the accused as a means of forcing the victim to submit; or } \\
\text { 4. rape accomplished where the victim is at the time unconscious of the nature of the act and this fact is } \\
\text { known to the accused; or } \\
\text { 5. rape accomplished with any person by means of force, violence, or threats of force or violence } \\
\text { accompanied by apparent power of execution regardless of the age of the person committing the crime; or } \\
\text { 6. rape by instrumentation resulting in bodily harm is rape by instrumentation in the first degree regardless } \\
\text { of the age of the person committing the crime; or } \\
\text { 7. rape by instrumentation committed upon a person under fourteen (14) years of age. } \\
\text { B. In all other cases, rape or rape by instrumentation is rape in the second degree. }\end{array}$ \\
\hline $\begin{array}{l}\text { Information Maintained in } \\
\text { Sex Offender Registry } \\
\text { (Oklahoma) }\end{array}$ & $\begin{array}{l}\text { 57 OKL. ST. ANN. } \$ 584 \text { (WEST 2008) } \\
\text { A. Any registration with the Department of Corrections required by the Sex Offenders Registration Act shall be in a } \\
\text { form approved by the Department and shall include the following information about the person registering: } \\
\text { 1. The name of the person and all aliases used or under which the person has been known; } \\
\text { 2. A complete description of the person, including a photograph and fingerprints, and when requested by the } \\
\text { Department of Corrections, such registrant shall submit to a blood or saliva test for purposes of a } \\
\text { deoxyribonucleic acid (DNA) profile. Submission to testing for individuals registering shall be within thirty }\end{array}$ \\
\hline
\end{tabular}

** Denotes those states where sex offender registration is required for convictions under the staff sexual misconduct laws of the states. Staff and 178 inmates could also be required to register as sex offenders if the offense were charged under other registrable offenses.

This publication is developed by the NIC/WCL Project on Addressing Prison Rape under NIC Cooperative Agreement 06S20GJJ1.

This is not to be posted or reproduced without permission from the authors.

American University, Washington College of Law

Current as of August 2009 


\section{Fifty State Survey of Adult Sex Offender Registration Requirements}

\section{NIC/WCL Project on Addressing Prison Rape}

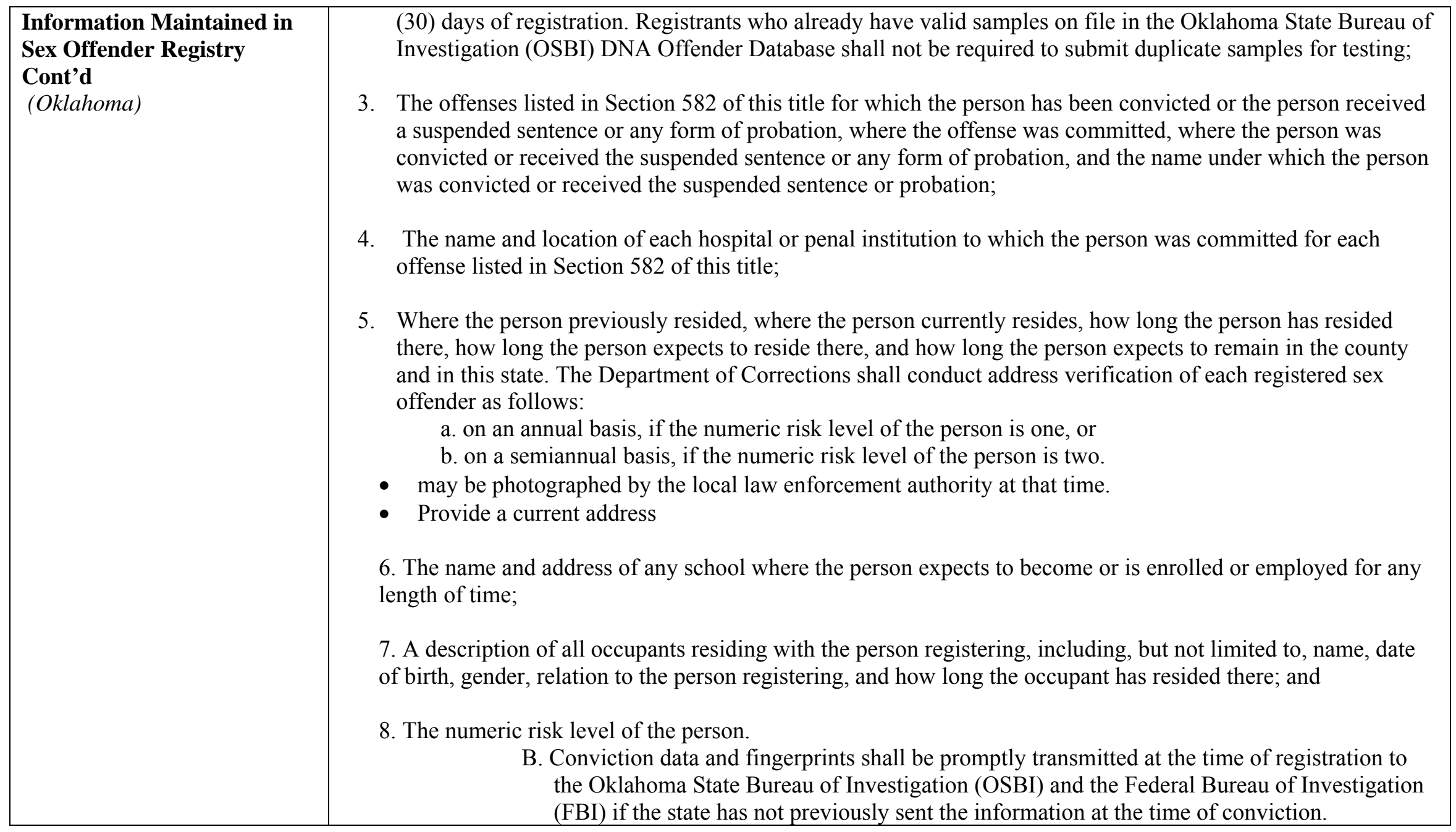

** Denotes those states where sex offender registration is required for convictions under the staff sexual misconduct laws of the states. Staff and inmates could also be required to register as sex offenders if the offense were charged under other registrable offenses.

This publication is developed by the NIC/WCL Project on Addressing Prison Rape under NIC Cooperative Agreement 06S20GJJ1.

This is not to be posted or reproduced without permission from the authors.

American University, Washington College of Law

Current as of August 2009 


\section{Fifty State Survey of Adult Sex Offender Registration Requirements}

\section{NIC/WCL Project on Addressing Prison Rape}

\begin{tabular}{|c|c|}
\hline $\begin{array}{l}\text { Community Notification } \\
\text { and Websites } \\
\text { (Oklahoma) }\end{array}$ & $\begin{array}{l}57 \text { OKL. ST. ANN. } \$ 584 \text { (WEST 2008) } \\
\text { E. } \\
\text { - The Department of Corrections shall maintain a file of all sex offender registrations. } \\
\text { - A copy of the information contained in the registration shall promptly be available to state, county and municipal } \\
\text { law enforcement agencies, the State Superintendent of Public Instruction, the Commissioner of Health, and the } \\
\text { National Sex Offender Registry maintained by the Federal Bureau of Investigation. } \\
\text { - The file shall promptly be made available for public inspection or copying pursuant to rules promulgated by the } \\
\text { Department of Corrections and may be made available through Internet access. } \\
\text { - The Department of Corrections shall promptly provide all municipal police departments, all county sheriff } \\
\text { departments and all campus police departments a list of those sex offenders registered and living in their county. } \\
\text { F. The Superintendent of Public Instruction is authorized to copy and shall distribute information from the sex } \\
\text { offender registry to school districts and individual public and private schools within the state. } \\
\text { G. The State Commissioner of Health is authorized to distribute information from the sex offender registry to any } \\
\text { nursing home or long-term care facility. } \\
\text { H. Each local law enforcement agency shall make its sex offender registry available upon request, without } \\
\text { restriction. }\end{array}$ \\
\hline $\begin{array}{l}\text { Limitations on Residency or } \\
\text { Employment } \\
\text { (Oklahoma) }\end{array}$ & $\begin{array}{l}57 \text { OKL. ST. ANN. } \S 590 \text { (West 2008) } \\
\text { A. Sex offenders may not establish residence within } 2000 \text { feet of any public or private school or educational } \\
\text { institution. } \\
\text { Sex offenders who lived within } 2000 \text { feet of a school prior to their sex offense conviction are not required } \\
\text { to sell their homes or move. }\end{array}$ \\
\hline
\end{tabular}

** Denotes those states where sex offender registration is required for convictions under the staff sexual misconduct laws of the states. Staff and inmates could also be required to register as sex offenders if the offense were charged under other registrable offenses.

This publication is developed by the NIC/WCL Project on Addressing Prison Rape under NIC Cooperative Agreement 06S20GJJ1.

This is not to be posted or reproduced without permission from the authors.

American University, Washington College of Law

Current as of August 2009 


\section{Fifty State Survey of Adult Sex Offender Registration Requirements}

\section{NIC/WCL Project on Addressing Prison Rape}

\begin{tabular}{|c|c|}
\hline $\begin{array}{l}\text { Duration of Registration } \\
\text { (Oklahoma) }\end{array}$ & $\begin{array}{l}57 \text { OKL. ST. ANN. } § 583 \text { (West 2008) } \\
\text { D. When a person has been convicted or received probation within the State of Oklahoma, the person shall be } \\
\text { required to register as follows: } \\
\text { 1. For a period of fifteen (15) years, if the numeric risk level of the person is one; } \\
\text { 2. For a period of twenty-five ( } 25 \text { ) years, if the numeric risk level of the person is two; and } \\
\text { 3. For life, if the numeric risk level of the person is three or the person has been classified as a habitual or } \\
\text { aggravated sex offender. } \\
\text { The registration period shall... be maintained by such authority for at least ten (10) years from the date of the last } \\
\text { registration. } \\
\text { OKLA. STAT. tit } 57, \S 584 \text { (West } 2008 \text { ) } \\
\text { Life for habitual sex offenders and aggravated sex offenders. }\end{array}$ \\
\hline & OREGON \\
\hline
\end{tabular}

** Denotes those states where sex offender registration is required for convictions under the staff sexual misconduct laws of the states. Staff and 181 inmates could also be required to register as sex offenders if the offense were charged under other registrable offenses.

This publication is developed by the NIC/WCL Project on Addressing Prison Rape under NIC Cooperative Agreement 06S20GJJ1.

This is not to be posted or reproduced without permission from the authors.

American University, Washington College of Law

Current as of August 2009 


\section{Fifty State Survey of Adult Sex Offender Registration Requirements}

\section{NIC/WCL Project on Addressing Prison Rape}

\begin{tabular}{|c|c|}
\hline $\begin{array}{l}\text { Registrable Offenses Cont'd } \\
\text { (Oregon) }\end{array}$ & 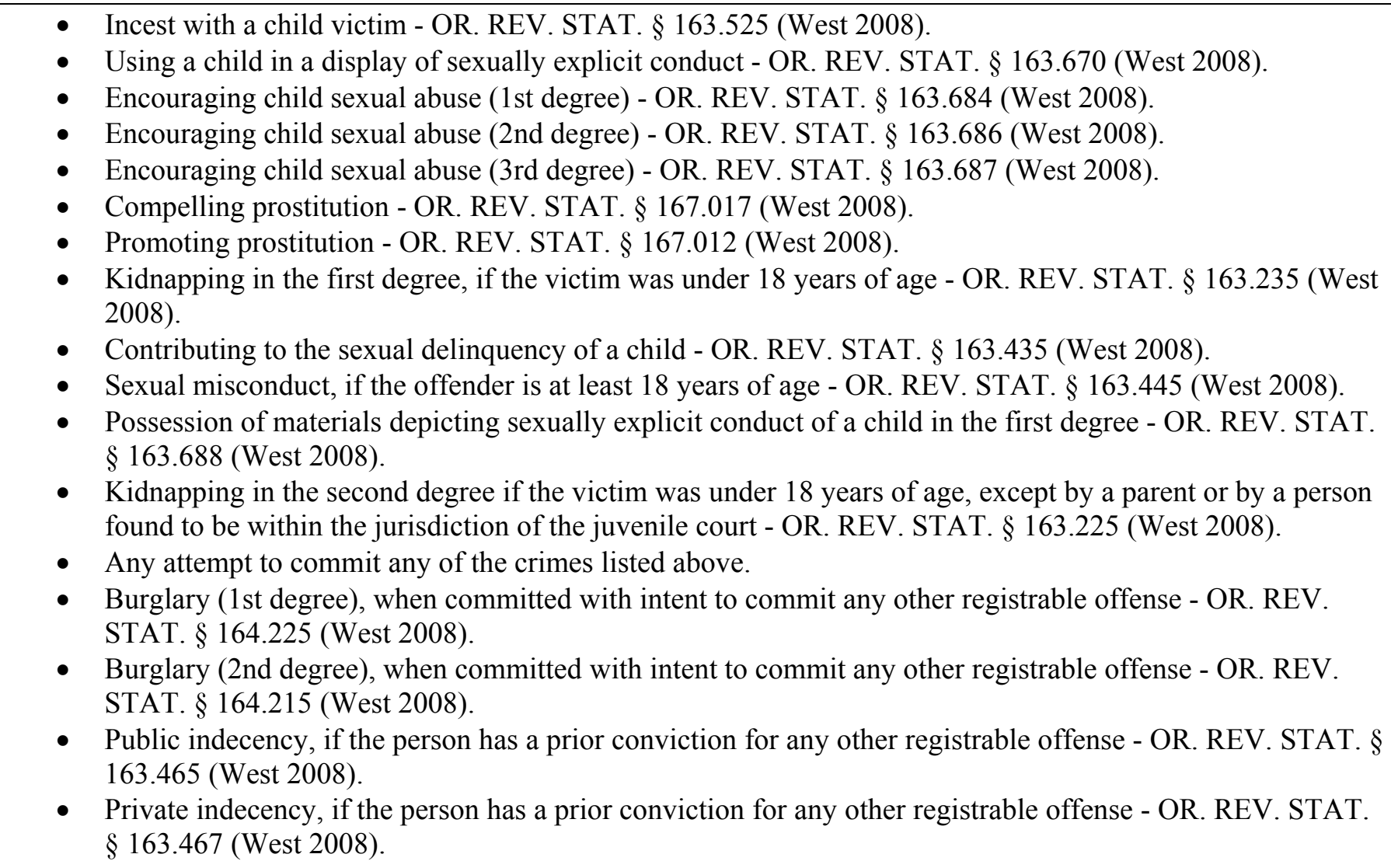 \\
\hline $\begin{array}{l}\text { Sex Offender Registration } \\
\text { Required for Staff Sexual } \\
\text { Misconduct? } \\
\text { (Oregon) }\end{array}$ & NO \\
\hline
\end{tabular}

** Denotes those states where sex offender registration is required for convictions under the staff sexual misconduct laws of the states. Staff and inmates could also be required to register as sex offenders if the offense were charged under other registrable offenses.

This publication is developed by the NIC/WCL Project on Addressing Prison Rape under NIC Cooperative Agreement 06S20GJJ1.

This is not to be posted or reproduced without permission from the authors.

American University, Washington College of Law

Current as of August 2009 


\section{Fifty State Survey of Adult Sex Offender Registration Requirements}

\section{NIC/WCL Project on Addressing Prison Rape}

\begin{tabular}{|c|c|}
\hline $\begin{array}{l}\text { Information Maintained in } \\
\text { Sex Offender Registry } \\
\text { (Oregon) }\end{array}$ & $\begin{array}{l}2009 \text { Oregon House Bill No. 3423, Oregon Seventy-Fifth Legislative Assembly March 12, } 2009 \\
\text { SECTION 7. ORS } 181.592 \text { is amended to read: } \\
\text { (d) (5) The information required to be made available under paragraph (c) of this subsection-posted on the Internet } \\
\text { website is: } \\
\text { (A) (a) The person's name and address, as described in ORS } 181.598 \text { (1)(a) and (b); } \\
\text { (B)-(b) A physical description of the person including, but not limited to, the person's age, height, weight } \\
\text { and eye and hair color; } \\
\text { (C) (c) The type of vehicle that the person is known to drive; } \\
\text { (D)-(d) Any conditions or restrictions upon the person's probation, parole, post-prison supervision or } \\
\text { conditional release; } \\
\text { (E)-(e) A description of the person's primary and secondary targets; } \\
\text { (F) (f) A list of the sex offenses for which the person has been convicted and a description of the person's } \\
\text { method of offense; } \\
\text { (G) (g) A current photograph of the person; } \\
\text { (H) (h) If the person is under supervision, the name or telephone number of the person's parole and } \\
\text { probation officer; and } \\
\text { (I)-(i) If the person is not under supervision, contact information for the Department of State Police. }\end{array}$ \\
\hline $\begin{array}{l}\text { Community Notification } \\
\text { and Websites } \\
\text { (Oregon) }\end{array}$ & $\begin{array}{l}\text { O.R.S. } \$ 181.592 \text { (West 2008) } \\
\text { (4)(a): } \\
\text { - The department shall make information about a person who is under supervision for the first time as a result of a } \\
\text { conviction for an offense that requires reporting as a sex offender accessible only by the use of the sex offender's } \\
\text { name. } \\
\text { - For all other sex offenders, the department may make the information accessible in any manner the department } \\
\text { chooses. }\end{array}$ \\
\hline
\end{tabular}

** Denotes those states where sex offender registration is required for convictions under the staff sexual misconduct laws of the states. Staff and 183 inmates could also be required to register as sex offenders if the offense were charged under other registrable offenses.

This publication is developed by the NIC/WCL Project on Addressing Prison Rape under NIC Cooperative Agreement 06S20GJJ1.

This is not to be posted or reproduced without permission from the authors.

American University, Washington College of Law

Current as of August 2009 


\section{Fifty State Survey of Adult Sex Offender Registration Requirements}

\section{NIC/WCL Project on Addressing Prison Rape}

\begin{tabular}{|c|c|}
\hline $\begin{array}{l}\text { Community Notification } \\
\text { and Websites Cont'd } \\
\text { (Oregon) }\end{array}$ & $\begin{array}{l}\text { (c) The department shall use the Internet to make the information available to the public if the information is } \\
\text { about a person: } \\
\text { (A) Determined to be a predatory sex offender; or } \\
\text { (B) Found to be a sexually violent dangerous offender. }\end{array}$ \\
\hline $\begin{array}{l}\text { Limitations on Residency or } \\
\text { Employment } \\
\text { (Oregon) }\end{array}$ & $\begin{array}{l}\text { O.R.S. } § 144.642 \text { (West 2008) } \\
\text { (1)(a) Sex offenders may not reside near locations where children are the primary occupants or users. } \\
\text { (1)(c) Unless authorized, sex offenders may not live with other sex offenders. }\end{array}$ \\
\hline $\begin{array}{l}\text { Duration of Registration } \\
\text { (Oregon) }\end{array}$ & $\begin{array}{l}\text { O.R.S. } \S 181.600 \text { (West 2008) } \\
\text { (1)(a) A registrant may petition for termination of the registration obligation after } 10 \text { years. }\end{array}$ \\
\hline \multicolumn{2}{|r|}{ PENNSYL VANIA** } \\
\hline $\begin{array}{l}\text { Registrable Offenses } \\
\text { (Pennsylvania) }\end{array}$ & 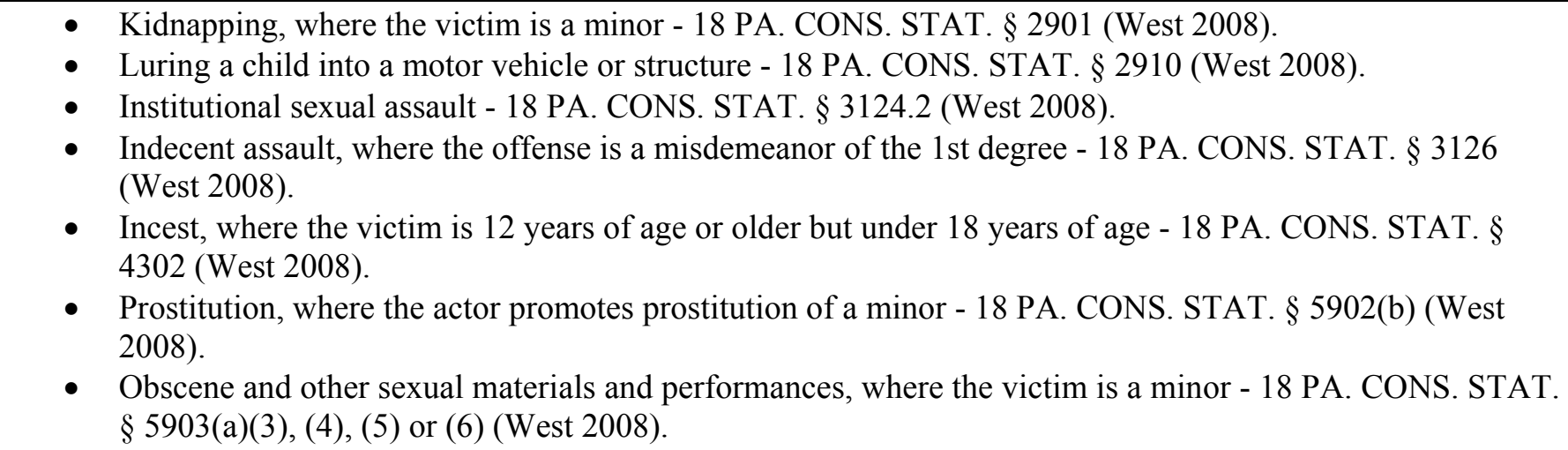 \\
\hline
\end{tabular}

** Denotes those states where sex offender registration is required for convictions under the staff sexual misconduct laws of the states. Staff and 184 inmates could also be required to register as sex offenders if the offense were charged under other registrable offenses.

This publication is developed by the NIC/WCL Project on Addressing Prison Rape under NIC Cooperative Agreement 06S20GJJ1.

This is not to be posted or reproduced without permission from the authors.

American University, Washington College of Law

Current as of August 2009 


\section{Fifty State Survey of Adult Sex Offender Registration Requirements}

\section{NIC/WCL Project on Addressing Prison Rape}

\begin{tabular}{|c|c|}
\hline $\begin{array}{l}\text { Registrable Offenses Cont'd } \\
\text { (Pennsylvania) }\end{array}$ & $\begin{array}{l}\text { - Sexual abuse of children - } 18 \text { PA. CONS. STAT. } \S 6312 \text { (West 2008). } \\
\text { - } \quad \text { Unlawful contact with minor - } 18 \text { PA. CONS. STAT. } \$ 6318 \text { (West 2008). } \\
\text { - } \text { The attempt to commit any of the above listed offenses. } \\
\text { - } \text { Rape - } 18 \text { PA. CONS. STAT. } \$ 3121 \text { (West 2008). } \\
\text { - Involuntary deviate sexual intercourse - } 18 \text { PA. CONS. STAT. } \S 3123 \text { (West 2008). } \\
\text { - } \text { Aggraval assault - } 18 \text { PA. CONS. STAT. } \$ 3124.1 \text { (West 2008). } \\
\text { - Incest, where the victim is under } 12 \text { years of age - } 18 \text { PA. CONS. STAT. } \S 4302 \text { (West 2008). } \\
\text { Offenders who move to Pennsylvania from another state are required to register. Such offenders must register } \\
\text { within } 10 \text { days of arriving in Pennsylvania. }\end{array}$ \\
\hline $\begin{array}{l}\text { Sex Offender Registration } \\
\text { Required for Staff Sexual } \\
\text { Misconduct? } \\
\text { (Pennsylvania) }\end{array}$ & $\begin{array}{l}\text { YES. } \\
18 \text { PA. C.S.A. } \S 3124.2 \text { (West 2008) } \\
\text { Institutional Sexual Assault } \\
\text { (a) a person who is an employee or agent of the Department of Corrections or a county correctional authority, youth } \\
\text { development center, youth forestry camp, State or county juvenile detention facility, other licensed residential } \\
\text { facility serving children and youth, or mental health or mental retardation facility or institution commits a felony of } \\
\text { the third degree when that person engages in sexual intercourse, deviate sexual intercourse or indecent contact with } \\
\text { an inmate, detainee, patient or resident. }\end{array}$ \\
\hline $\begin{array}{l}\text { Information Maintained in } \\
\text { Sex Offender Registry } \\
\text { (Pennsylvania) }\end{array}$ & $\begin{array}{l}42 \text { PA. C.S.A. } \S 9795.2 \text { (West 2008) } \\
\text { (c)(1): } \\
\text { • name }\end{array}$ \\
\hline
\end{tabular}

** Denotes those states where sex offender registration is required for convictions under the staff sexual misconduct laws of the states. Staff and inmates could also be required to register as sex offenders if the offense were charged under other registrable offenses.

This publication is developed by the NIC/WCL Project on Addressing Prison Rape under NIC Cooperative Agreement 06S20GJJ1.

This is not to be posted or reproduced without permission from the authors.

American University, Washington College of Law

Current as of August 2009 


\section{Fifty State Survey of Adult Sex Offender Registration Requirements}

\section{NIC/WCL Project on Addressing Prison Rape}

\begin{tabular}{|c|c|}
\hline $\begin{array}{l}\text { Information Maintained in } \\
\text { Sex Offender Registry } \\
\text { Cont'd } \\
\text { (Pennsylvania) }\end{array}$ & $\begin{array}{l}\text { - all current or intended residences } \\
\text { - all information concerning current or intended employment } \\
\text { - all information concerning current or intended enrollment as a student }\end{array}$ \\
\hline $\begin{array}{l}\text { Community Notification } \\
\text { and Websites } \\
\text { (Pennsylvania) }\end{array}$ & $\begin{array}{l}42 \text { PA. C.S.A. } \$ 9798 \text { (West 2008) } \\
\text { (b)The chief law enforcement officer shall provide written notice, to the following persons: } \\
\text { (1) Neighbors of the sexually violent predator. As used in this paragraph, where the sexually violent } \\
\text { predator lives in a common interest community, the term "neighbor" includes the unit owners' } \\
\text { (2) association and residents of the common interest community. } \\
\text { (2) The director of the county children and youth service agency of the county where the sexually } \\
\text { violent predator resides. } \\
\text { (3) The superintendent of each school district and the equivalent } \\
\text { (3) official for private and parochial schools enrolling students up } \\
\text { through grade } 12 \text { in the municipality where the sexually violent predator resides . } \\
\text { (3.1) The superintendent of each school district and the equivalent official for each private and } \\
\text { parochial school located within a one-mile radius of where the sexually violent predator resides. } \\
\text { (4) The licensee of each certified day care center and licensed preschool program and owner/operator of } \\
\text { each registered family day care home in the municipality where the sexually violent predator resides. } \\
\text { (5) The president of each college, university and community college } \\
\text { located within } 1,000 \text { feet of a sexually violent predator's residence. } \\
\text { 42 PA. C.S.A. } § 9798.1 \text { (West } 2008 \text { ) } \\
\text { (a) It is hereby declared to be the finding of the General Assembly that public safety will be enhanced by making } \\
\text { information about sexually violent predators, lifetime registrants and other sex offenders available to the public } \\
\text { through the Internet. }\end{array}$ \\
\hline
\end{tabular}

** Denotes those states where sex offender registration is required for convictions under the staff sexual misconduct laws of the states. Staff and inmates could also be required to register as sex offenders if the offense were charged under other registrable offenses.

This publication is developed by the NIC/WCL Project on Addressing Prison Rape under NIC Cooperative Agreement 06S20GJJ1.

This is not to be posted or reproduced without permission from the authors.

American University, Washington College of Law

Current as of August 2009 


\section{Fifty State Survey of Adult Sex Offender Registration Requirements}

\section{NIC/WCL Project on Addressing Prison Rape}

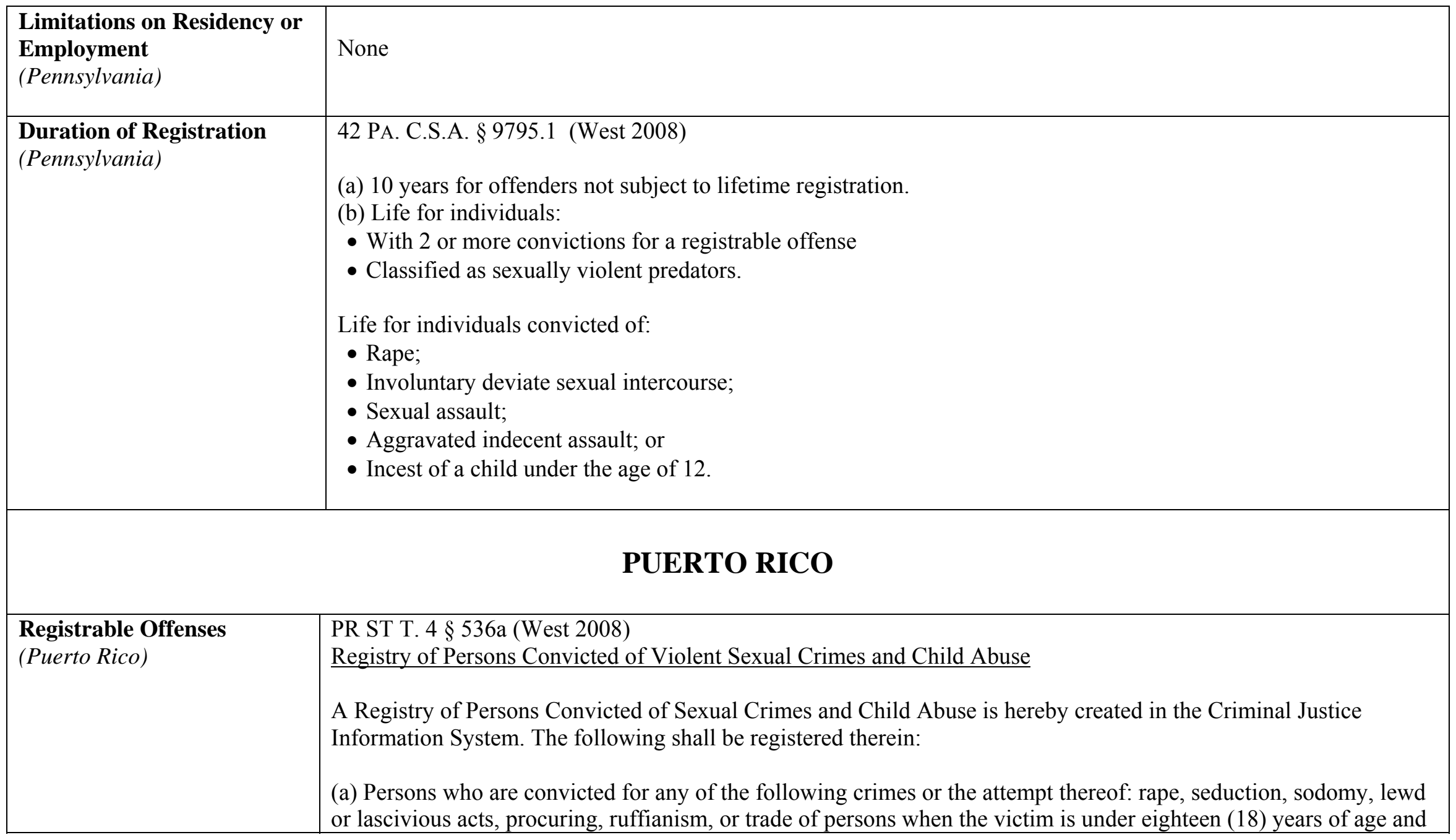

** Denotes those states where sex offender registration is required for convictions under the staff sexual misconduct laws of the states. Staff and 187 inmates could also be required to register as sex offenders if the offense were charged under other registrable offenses.

This publication is developed by the NIC/WCL Project on Addressing Prison Rape under NIC Cooperative Agreement 06S20GJJ1.

This is not to be posted or reproduced without permission from the authors.

American University, Washington College of Law

Current as of August 2009 


\section{Fifty State Survey of Adult Sex Offender Registration Requirements}

\section{NIC/WCL Project on Addressing Prison Rape}

\begin{tabular}{|c|c|}
\hline $\begin{array}{l}\text { Registrable Offenses Cont'd } \\
\text { (Puerto Rico) }\end{array}$ & $\begin{array}{l}\text { the offense is aggravated; crimes against the protection of children, incest, restraint of freedom when the victim is } \\
\text { under sixteen (16) years and not his/her child, kidnapping when the victim is under eighteen (18) years of age and is } \\
\text { not his/her child; child theft, child perversion when a child under eighteen (18) years of age is admitted or held in a } \\
\text { house of prostitution or sodomy; aggravated abuse against a child and conjugal sexual aggression comprised in } \\
\text { Articles } 99,101,103,105110(\mathrm{a}) \text { and (c) and } 111,115122,131(\mathrm{c}), 137 \mathrm{~A}(\mathrm{a}), 160 \text { and } 163(\mathrm{c}) \text { of Act No. } 115 \text { of July } \\
22,1974 \text {, as amended, and in } \S \S 632(\mathrm{~g}) \text { and } 635 \text { of Title } 8 \text {, and in the crime of child abuse established in } \S \S 477 \mathrm{u} \\
\text { and } 447 \mathrm{v} \text { of Title } 8 \text {, respectively. } \\
\text { (b) Persons who have been or are convicted for crimes similar to those listed in this section by a federal, state or } \\
\text { military court who transfer to Puerto Rico to establish their domicile, or that for reason of work or study are living in } \\
\text { Puerto Rico, although their intention is not that of establishing their domicile in the Commonwealth. } \\
\text { (c) Persons who, at the time of the approval of this act, are imprisoned or participating in a diversion program of the } \\
\text { Corrections Administration for committing any of the crimes listed in this section, and those persons whose parole } \\
\text { has been revoked for failure to comply with any condition thereof. } \\
\text { (d) Those persons who, at the time of the approval of this act, had the obligation to register under Act No. } 28 \text { of July } \\
1,1997, \text { shall be registered. Furthermore, those persons who, at the time of the approval of this act, have served the } \\
\text { penalty imposed for the commission of any of the crimes listed in this section shall not have the obligation to } \\
\text { register. }\end{array}$ \\
\hline $\begin{array}{l}\text { Sex Offender Registration } \\
\text { Required for Staff Sexual } \\
\text { Misconduct? } \\
\text { (Puerto Rico) }\end{array}$ & NO \\
\hline $\begin{array}{l}\text { Information Maintained in } \\
\text { Sex Offender Registry } \\
\text { (Puerto Rico) }\end{array}$ & $\begin{array}{l}\text { PR ST T. } 4 \S 536 \text { b (West 2008) } \\
\text { (a) At the time of the sentencing, the court with jurisdiction shall direct the Prosecutor to notify the System of the } \\
\text { following information: names, pseudonyms, date of birth, home address, driver's license number, social security }\end{array}$ \\
\hline
\end{tabular}

** Denotes those states where sex offender registration is required for convictions under the staff sexual misconduct laws of the states. Staff and 188 inmates could also be required to register as sex offenders if the offense were charged under other registrable offenses.

This publication is developed by the NIC/WCL Project on Addressing Prison Rape under NIC Cooperative Agreement 06S20GJJ1.

This is not to be posted or reproduced without permission from the authors.

American University, Washington College of Law

Current as of August 2009 


\section{Fifty State Survey of Adult Sex Offender Registration Requirements}

\section{NIC/WCL Project on Addressing Prison Rape}

\begin{tabular}{|c|c|}
\hline $\begin{array}{l}\text { Information Maintained in } \\
\text { Sex Offender Registry } \\
\text { (Puerto Rico) }\end{array}$ & $\begin{array}{l}\text { number, fingerprints, photograph and other essential data that shall be furnished by persons subjected to the Registry } \\
\text { as provided by } \S \S 536-536 \mathrm{~h} \text { of this title. All information thus compiled shall be registered within fifteen (15) days as } \\
\text { of the court order. }\end{array}$ \\
\hline $\begin{array}{l}\text { Community Notification } \\
\text { and Websites } \\
\text { (Puerto Rico) }\end{array}$ & $\begin{array}{l}\text { PR ST T. } 4 \S 536 \text { e (West 2008) } \\
\text { The information on a registered person found in the System, as provided in } \S \S 536-536 \mathrm{~h} \text { of this title, shall be } \\
\text { immediately available for law enforcement agencies as well as the state or federal government agencies in the } \\
\text { performance of their duties. Said information shall also be provided to every person who requests it in writing, } \\
\text { including such persons and private institutions for which this information is of interest due to the nature of their } \\
\text { activities, in view of the threat and danger posed to them by the persons who commit any of the crimes listed in } \S \S \\
536-536 h \text { of this title. This includes, without it being understood as a limitation, the victim and his/her family, } \\
\text { schools, institutions and child-care establishment, recreational facilities and institutions for abused children and } \\
\text { women. The System shall approve the regulations needed for the information to be available to the public. In these } \\
\text { cases, the information registered in the System shall be provided by the Puerto Rico Police. The name of the victim } \\
\text { of the crime shall not be revealed. } \\
\text { The information that appears in the Registry shall be transmitted electronically by the National Sex Offender } \\
\text { Registry (NSOR) of the Federal Bureau of Investigation. } \\
\text { PR ST T. } 4 \S 536 f \text { (West 2008) } \\
\text { The System is empowered to publish the name, address and other pertinent information through the Internet. }\end{array}$ \\
\hline $\begin{array}{l}\text { Limitations on Residency } \\
\text { or Employment } \\
\text { (Puerto Rico) }\end{array}$ & None. \\
\hline
\end{tabular}

** Denotes those states where sex offender registration is required for convictions under the staff sexual misconduct laws of the states. Staff and inmates could also be required to register as sex offenders if the offense were charged under other registrable offenses.

This publication is developed by the NIC/WCL Project on Addressing Prison Rape under NIC Cooperative Agreement 06S20GJJ1.

This is not to be posted or reproduced without permission from the authors.

American University, Washington College of Law

Current as of August 2009 


\section{Fifty State Survey of Adult Sex Offender Registration Requirements}

\section{NIC/WCL Project on Addressing Prison Rape}

\begin{tabular}{|c|c|}
\hline $\begin{array}{l}\text { Duration of Registration } \\
\text { (Puerto Rico) }\end{array}$ & $\begin{array}{l}\text { PR ST T. } 4 \S 536 \text { d (West 2008) } \\
\text { The person declared a dangerous sexual offender shall be registered for life, as provided in } \S \S 536-536 \mathrm{~h} \text { of this title. }\end{array}$ \\
\hline & RHODE ISLAND \\
\hline $\begin{array}{l}\text { Registrable Offenses } \\
\text { (Rhode Island) }\end{array}$ & 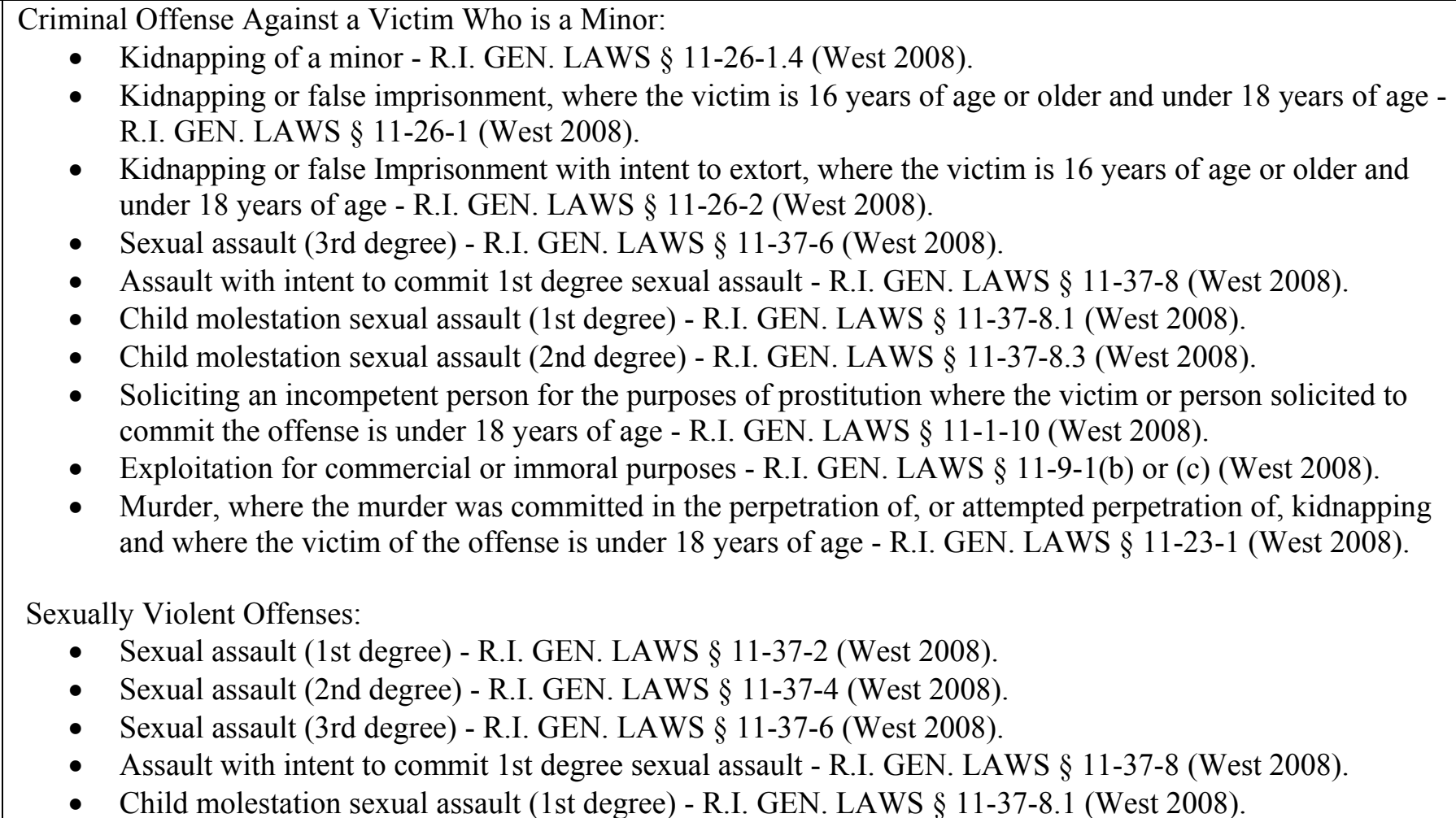 \\
\hline
\end{tabular}

** Denotes those states where sex offender registration is required for convictions under the staff sexual misconduct laws of the states. Staff and 190 inmates could also be required to register as sex offenders if the offense were charged under other registrable offenses.

This publication is developed by the NIC/WCL Project on Addressing Prison Rape under NIC Cooperative Agreement 06S20GJJ1.

This is not to be posted or reproduced without permission from the authors.

American University, Washington College of Law

Current as of August 2009 


\section{Fifty State Survey of Adult Sex Offender Registration Requirements}

\section{NIC/WCL Project on Addressing Prison Rape}

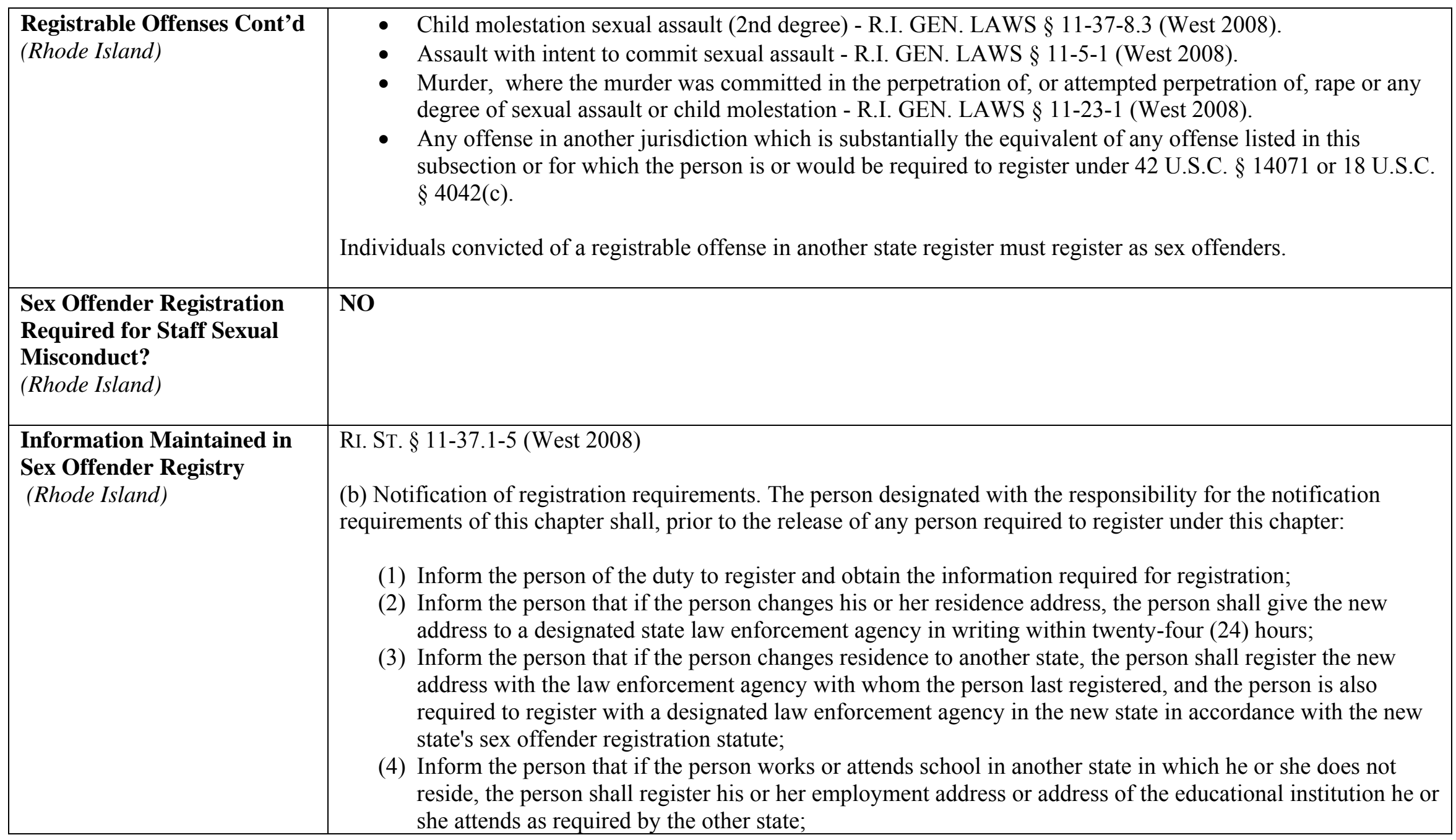

** Denotes those states where sex offender registration is required for convictions under the staff sexual misconduct laws of the states. Staff and 191 inmates could also be required to register as sex offenders if the offense were charged under other registrable offenses.

This publication is developed by the NIC/WCL Project on Addressing Prison Rape under NIC Cooperative Agreement 06S20GJJ1.

This is not to be posted or reproduced without permission from the authors.

American University, Washington College of Law

Current as of August 2009 


\section{Fifty State Survey of Adult Sex Offender Registration Requirements}

\section{NIC/WCL Project on Addressing Prison Rape}

\begin{tabular}{|c|c|}
\hline $\begin{array}{l}\text { Information Maintained in } \\
\text { Sex Offender Registry } \\
\text { Cont'd } \\
\text { (Rhode Island) }\end{array}$ & $\begin{array}{l}\text { (5) Obtain fingerprints and a photograph of the person if these have not already been obtained in connection } \\
\text { with the offense that triggers registration; and } \\
\text { (6) Require the person to read and sign a form approved by the attorney general stating that the duty of the } \\
\text { person to register under this section has been explained. } \\
\text { (c) Registration information. In addition to the requirements of subsection (b) of this section, for a person required } \\
\text { to register under } \S 11-37.1-3 \text {, then the person responsible for the notification required under subsection (b) of this } \\
\text { section shall obtain the name of the person, identifying factors, anticipated future residence, juvenile and adult } \\
\text { offense history, and documentation of any treatment received for the mental abnormality or personality disorder of } \\
\text { the person. }\end{array}$ \\
\hline $\begin{array}{l}\text { Community Notification } \\
\text { and Websites } \\
\text { (Rhode Island) }\end{array}$ & $\begin{array}{l}\text { RI. ST. } \$ 11-37.1-12 \text { (West 2008) } \\
\text { (b) The regulations shall provide for three (3) levels of notification depending upon the risk of re-offense level of } \\
\text { the sex offender: } \\
\text { (1) If risk of re-offense is low, law enforcement agencies and any individuals identified in accordance with the } \\
\text { parole board guidelines shall be notified; } \\
\text { (2) If risk of re-offense is moderate, organizations in the community likely to encounter the person registered } \\
\text { shall be notified in accordance with the parole board's guidelines, in addition to the notice required by } \\
\text { subdivision (1) of this subsection; } \\
\text { (3) If risk of re-offense is high, the members of the public likely to encounter the person registered shall be } \\
\text { notified through means in accordance with the parole board's guidelines designed to reach members of the } \\
\text { public likely to encounter the person registered, in addition to the notice required by subdivisions (1) and (2) } \\
\text { of this subsection } \\
\text { (4) The sex offender community notification unit is authorized and directed to utilize the Rhode Island state } \\
\text { police web site and the Rhode Island Unified Court System website for the public release of identifying } \\
\text { information of level two and level three sex offenders who have been convicted, provided that no identifying } \\
\text { information of a juvenile shall be listed on the web site. }\end{array}$ \\
\hline
\end{tabular}

** Denotes those states where sex offender registration is required for convictions under the staff sexual misconduct laws of the states. Staff and inmates could also be required to register as sex offenders if the offense were charged under other registrable offenses.

This publication is developed by the NIC/WCL Project on Addressing Prison Rape under NIC Cooperative Agreement 06S20GJJ1.

This is not to be posted or reproduced without permission from the authors.

American University, Washington College of Law

Current as of August 2009 


\section{Fifty State Survey of Adult Sex Offender Registration Requirements}

\section{NIC/WCL Project on Addressing Prison Rape}

\begin{tabular}{|c|c|}
\hline $\begin{array}{l}\text { Limitations on Residency or } \\
\text { Employment } \\
\text { (Rhode Island) }\end{array}$ & None. \\
\hline $\begin{array}{l}\text { Duration of Registration } \\
\text { (Rhode Island) }\end{array}$ & $\begin{array}{l}\text { RI. ST. } § 11-37.1-4 \text { (West 2008) } \\
\text { (a) } 10 \text { years for persons not subject to lifetime registration. } \\
\text { (a) Life for sexually violent predators, recidivists, and aggravated crime offenders. }\end{array}$ \\
\hline & SOUTH CAROLINA** \\
\hline $\begin{array}{l}\text { Registrable Offenses } \\
\text { (South Carolina) }\end{array}$ & 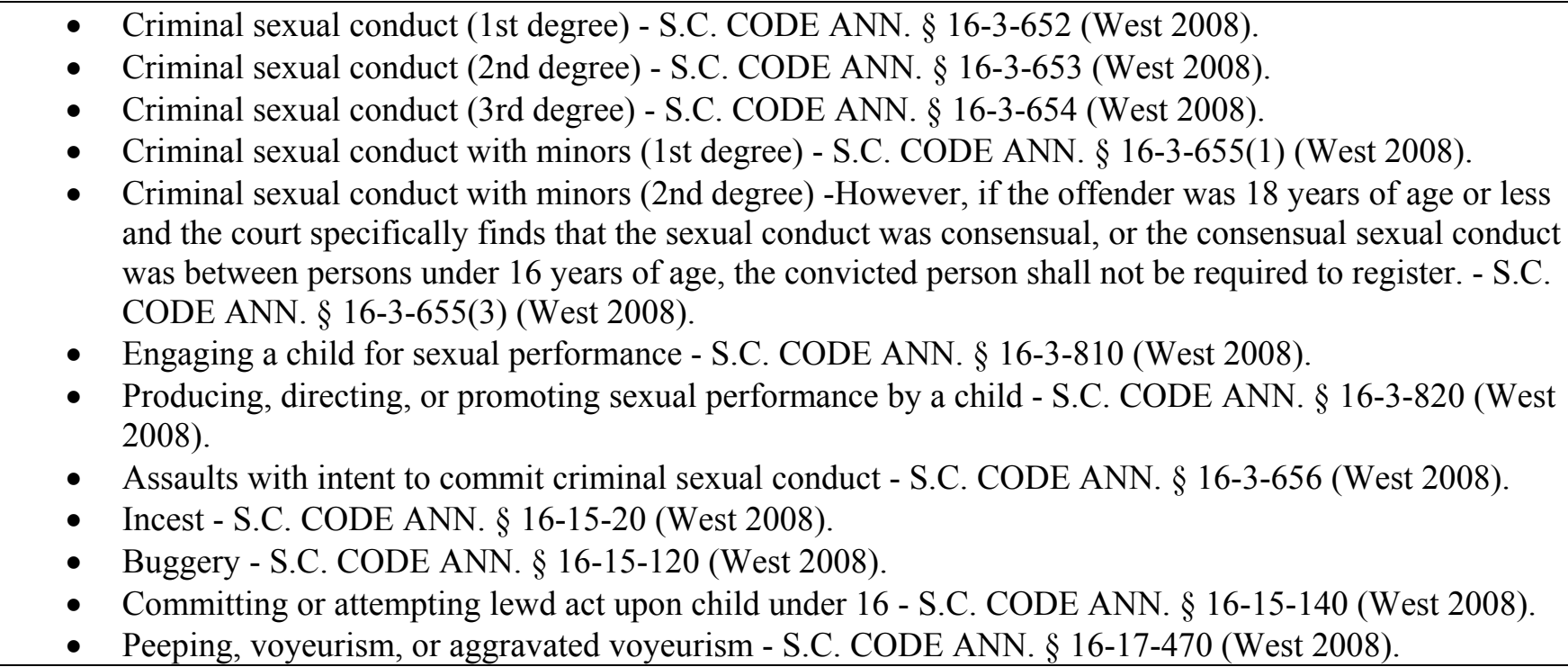 \\
\hline
\end{tabular}

** Denotes those states where sex offender registration is required for convictions under the staff sexual misconduct laws of the states. Staff and 193 inmates could also be required to register as sex offenders if the offense were charged under other registrable offenses.

This publication is developed by the NIC/WCL Project on Addressing Prison Rape under NIC Cooperative Agreement 06S20GJJ1.

This is not to be posted or reproduced without permission from the authors.

American University, Washington College of Law

Current as of August 2009 


\section{Fifty State Survey of Adult Sex Offender Registration Requirements}

\section{NIC/WCL Project on Addressing Prison Rape}

\begin{tabular}{|c|c|}
\hline $\begin{array}{l}\text { Registrable Offenses Cont'd } \\
\text { (South Carolina) }\end{array}$ & 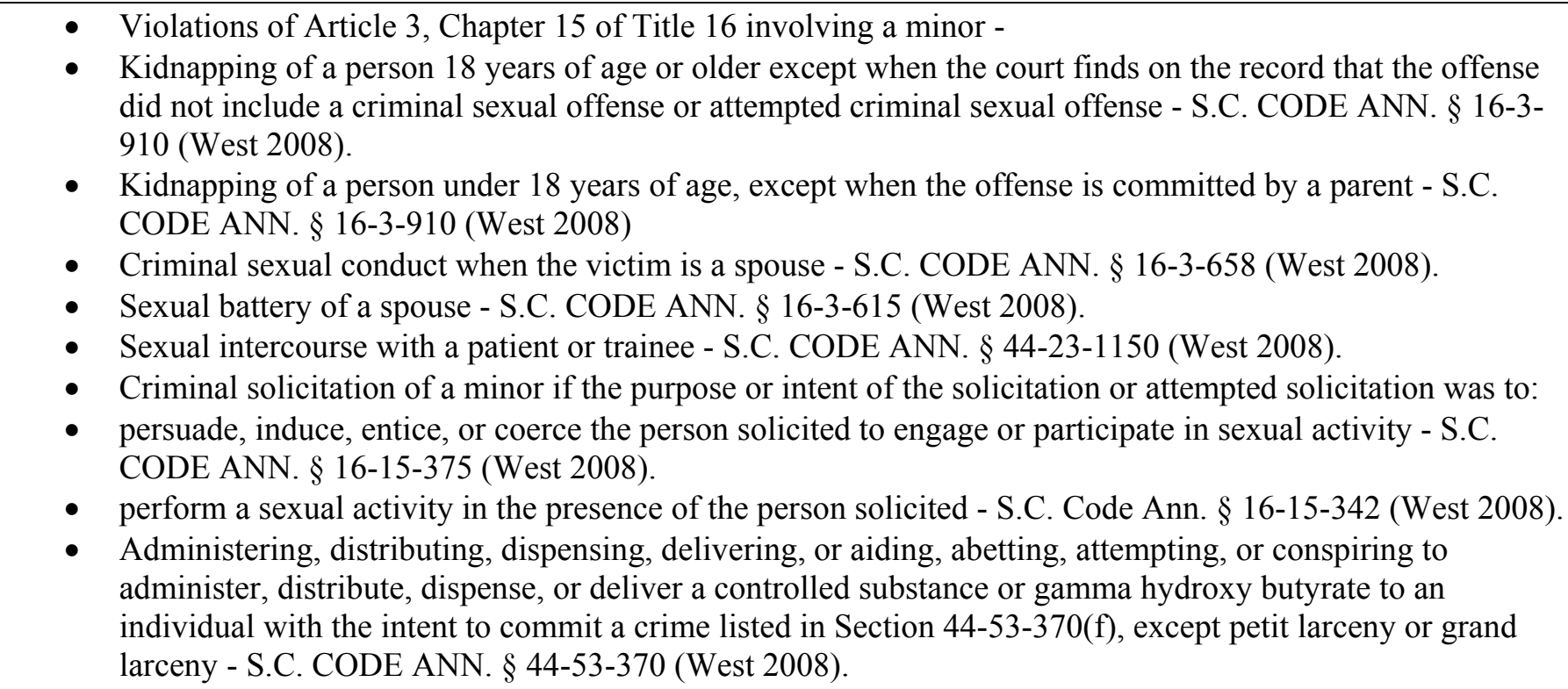 \\
\hline
\end{tabular}

** Denotes those states where sex offender registration is required for convictions under the staff sexual misconduct laws of the states. Staff and inmates could also be required to register as sex offenders if the offense were charged under other registrable offenses.

This publication is developed by the NIC/WCL Project on Addressing Prison Rape under NIC Cooperative Agreement 06S20GJJ1.

This is not to be posted or reproduced without permission from the authors.

American University, Washington College of Law

Current as of August 2009 


\section{Fifty State Survey of Adult Sex Offender Registration Requirements}

\section{NIC/WCL Project on Addressing Prison Rape}

\begin{tabular}{|c|c|}
\hline $\begin{array}{l}\text { Sex Offender Registration } \\
\text { Required for Staff Sexual } \\
\text { Misconduct? Cont'd } \\
\text { (South Carolina) }\end{array}$ & $\begin{array}{l}\text { conviction, must be imprisoned for not more than } 1 \text { year. } \\
\text { (E) A person who has knowledge of sexual misconduct who has received information in the person's professional } \\
\text { capacity and fails to report it to the appropriate law enforcement authority, or a person who threatens or attempts to } \\
\text { intimidate a witness is guilty of a misdemeanor and upon conviction, must be imprisoned for not more than } 6 \\
\text { months, or both. }\end{array}$ \\
\hline $\begin{array}{l}\text { Information Maintained in } \\
\text { Sex Offender Registry } \\
\text { (South Carolina) }\end{array}$ & $\begin{array}{l}\text { SC. ST. } § 23-3-440 \text { (West 2008) } \\
\text { (1) } \\
\text { - name } \\
\text { - offender's description } \\
\text { - photograph } \\
\text { - other information required by the State Law Enforcement Division }\end{array}$ \\
\hline $\begin{array}{l}\text { Community Notification } \\
\text { and Websites } \\
\text { (South Carolina) }\end{array}$ & $\begin{array}{l}\text { SC. ST. } § 23-3-490 \text { (West 2008) } \\
\text { (A) Information collected for the offender registry is open to public inspection, upon request to the county sheriff. } \\
\text { (c)The sheriff shall notify the principals of public and private schools, and the administrator of child day care } \\
\text { centers and family day care centers of any offender whose address is within one-half mile of the school or business. } \\
\text { (E) For purposes of this section, use of computerized or electronic transmission of data or other electronic or similar } \\
\text { means is permitted. }\end{array}$ \\
\hline $\begin{array}{l}\text { Limitations on Residency or } \\
\text { Employment } \\
\text { (South Carolina) }\end{array}$ & None. \\
\hline
\end{tabular}

** Denotes those states where sex offender registration is required for convictions under the staff sexual misconduct laws of the states. Staff and inmates could also be required to register as sex offenders if the offense were charged under other registrable offenses.

This publication is developed by the NIC/WCL Project on Addressing Prison Rape under NIC Cooperative Agreement 06S20GJJ1.

This is not to be posted or reproduced without permission from the authors.

American University, Washington College of Law

Current as of August 2009 


\section{Fifty State Survey of Adult Sex Offender Registration Requirements}

\section{NIC/WCL Project on Addressing Prison Rape}

\begin{tabular}{|c|c|}
\hline $\begin{array}{l}\text { Duration of Registration } \\
\text { (South Carolina) }\end{array}$ & $\begin{array}{l}\text { SC. ST. } \$ 44-23-1150 \text { (West 2008) } \\
\text { Sexual Misconduct with a patient, trainee or offender } \\
\text { (B) An actor is guilty of sexual misconduct when the actor, knowing that the victim is an inmate, offender, or } \\
\text { patient voluntarily engages with the victim in an act of sexual intercourse, whether vaginal, oral, or anal, or other } \\
\text { sexual contact for the purpose of sexual gratification. } \\
\text { (A) As used in this section: } \\
\text { o "Actor" means an employee, volunteer, agent, or contractor of a public entity that has statutory or } \\
\text { contractual responsibility for inmates or patients confined in a prison, jail, or mental health facility. } \\
\text { Actor includes individuals who supervise inmate labor details outside of an institution or who have } \\
\text { supervisory responsibility for offenders on parole, probation, or other community supervision } \\
\text { programs. }\end{array}$ \\
\hline \multicolumn{2}{|r|}{ SOUTH DAKOTA } \\
\hline
\end{tabular}

** Denotes those states where sex offender registration is required for convictions under the staff sexual misconduct laws of the states. Staff and 196 inmates could also be required to register as sex offenders if the offense were charged under other registrable offenses.

This publication is developed by the NIC/WCL Project on Addressing Prison Rape under NIC Cooperative Agreement 06S20GJJ1.

This is not to be posted or reproduced without permission from the authors.

American University, Washington College of Law

Current as of August 2009 


\section{Fifty State Survey of Adult Sex Offender Registration Requirements}

\section{NIC/WCL Project on Addressing Prison Rape}

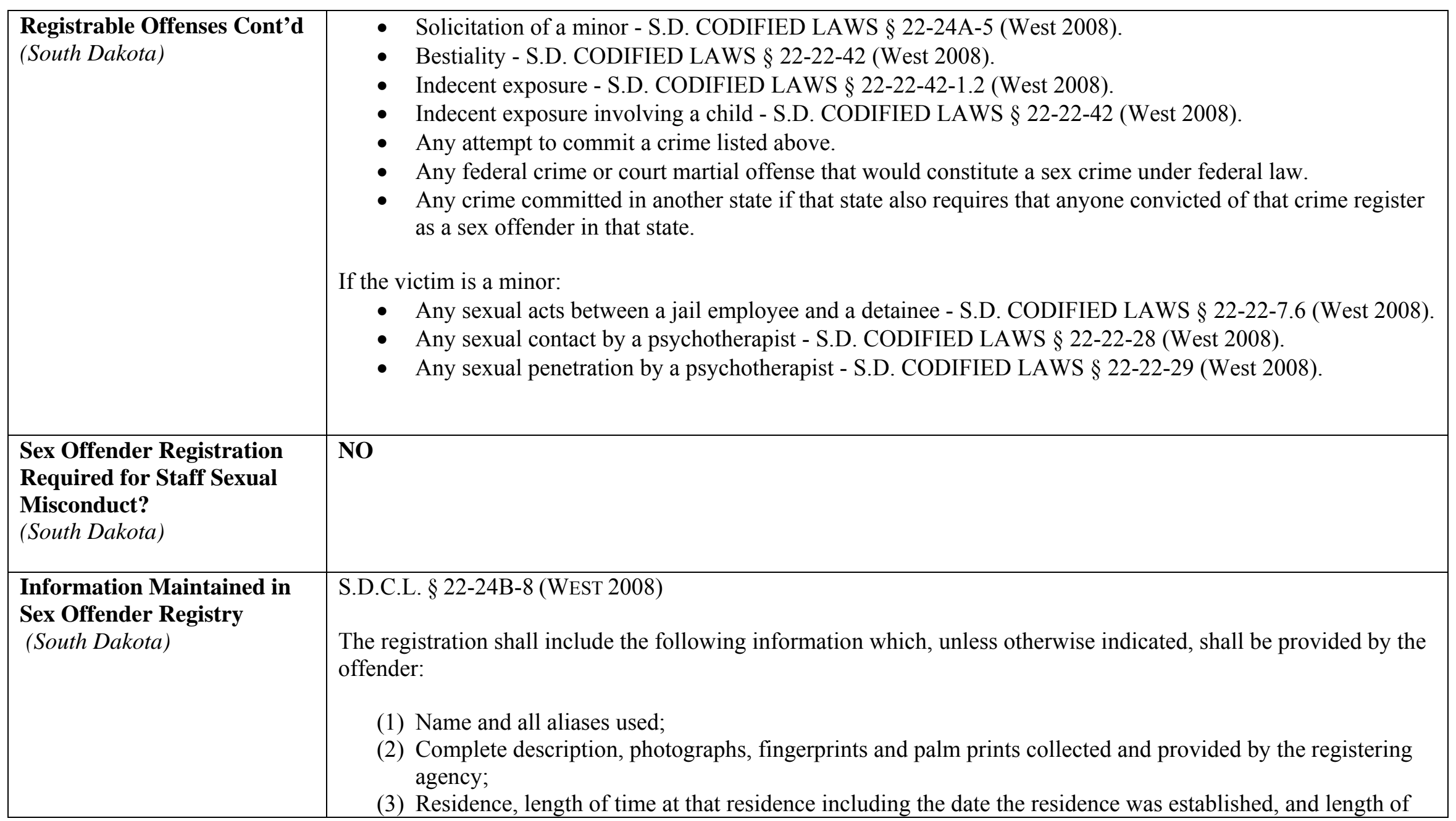

** Denotes those states where sex offender registration is required for convictions under the staff sexual misconduct laws of the states. Staff and inmates could also be required to register as sex offenders if the offense were charged under other registrable offenses.

This publication is developed by the NIC/WCL Project on Addressing Prison Rape under NIC Cooperative Agreement 06S20GJJ1.

This is not to be posted or reproduced without permission from the authors.

American University, Washington College of Law

Current as of August 2009 


\section{Fifty State Survey of Adult Sex Offender Registration Requirements}

\section{NIC/WCL Project on Addressing Prison Rape}

\begin{tabular}{|c|c|}
\hline $\begin{array}{l}\text { Information Maintained in } \\
\text { Sex Offender Registry } \\
\text { Cont'd } \\
\text { (South Dakota) }\end{array}$ & $\begin{array}{l}\text { time expected to remain at that residence; } \\
\text { (4) The type of sex crime convicted of; } \\
\text { (5) The date of commission and the date of conviction of any sex crime committed; } \\
\text { (6) Social Security number on a separate confidential form; } \\
\text { (7) Driver license number and state of issuance; } \\
\text { (8) Whether or not the registrant is receiving or has received any sex offender treatment; } \\
\text { (9) Employer name, address, and phone number or school name, address, and phone number } \\
\text { (10) Length of employment or length of attendance at school; } \\
\text { (11) Occupation or vocation; } \\
\text { (12) Vehicle license plate number of any vehicle owned by the offender; } \\
\text { (13) Information identifying any internet accounts of the offender as well as any user names, screen names, } \\
\text { and aliases that the offender uses on the internet; } \\
\text { (14) A listing of all felony convictions, in any jurisdiction, for crimes committed as an adult and sex offense } \\
\text { convictions and adjudications subject to sex offender registry provided by the offender and confirmed by } \\
\text { the registering agency; } \\
\text { (15) A description of the offense, provided by the prosecuting attorney; } \\
\text { (16) Acknowledgment whether the offender is currently an inmate, parolee, juvenile in department of } \\
\text { corrections placement or under aftercare supervision, county or city jail inmate or detainee in a juvenile } \\
\text { detention center, provided by the offender and confirmed by the administering body of the correctional } \\
\text { facility; } \\
\text { (17) Acknowledgment whether the offender is subject to community safety zone restrictions, provided by the } \\
\text { registering agency; and } \\
\text { (18) The name, address and phone number of two local contacts, who have regular interaction with the } \\
\text { offender and the name, address and phone number of the offender's next of kin. }\end{array}$ \\
\hline $\begin{array}{l}\text { Community Notification } \\
\text { and Websites } \\
\text { (South Dakota) }\end{array}$ & $\begin{array}{l}\text { S.D.C.L. } \$ 22-24 B-15 \text { (West 2008) } \\
\text { Registration records collected by local law enforcement agencies pursuant to this chapter, registration lists provided } \\
\text { to local law enforcement by the Division of Criminal Investigation, and records collected by institutions for those } \\
\text { persons required to register are public records. }\end{array}$ \\
\hline
\end{tabular}

** Denotes those states where sex offender registration is required for convictions under the staff sexual misconduct laws of the states. Staff and inmates could also be required to register as sex offenders if the offense were charged under other registrable offenses.

This publication is developed by the NIC/WCL Project on Addressing Prison Rape under NIC Cooperative Agreement 06S20GJJ1.

This is not to be posted or reproduced without permission from the authors.

American University, Washington College of Law

Current as of August 2009 


\section{Fifty State Survey of Adult Sex Offender Registration Requirements}

\section{NIC/WCL Project on Addressing Prison Rape}

\begin{tabular}{|c|c|}
\hline $\begin{array}{l}\text { Community Notification } \\
\text { and Websites Cont'd } \\
\text { (South Dakota) }\end{array}$ & $\begin{array}{l}\text { S.D.C.L. } \S 22-24 B-21 \\
\text { The Division of Criminal Investigation shall post and maintain on an internet site sex offender registration } \\
\text { information. }\end{array}$ \\
\hline $\begin{array}{l}\text { Limitations on Residency or } \\
\text { Employment } \\
\text { (South Dakota) }\end{array}$ & $\begin{array}{l}\text { S.D.C.L. } \S 22-24 B-23 \text { (West 2008) } \\
\text { No person who is required to register as a sex offender pursuant to this chapter may establish a residence or reside } \\
\text { within a community safety zone unless: } \\
\text { (1) The person is incarcerated in a jail or prison or other correctional placement which is located within a } \\
\text { community safety zone; } \\
\text { (2) The person is placed in a health care facility licensed pursuant to chapter } 34-12 \text {, or certified under Title } \\
\text { XVIII or XIX of the Social Security Act as amended to December } 31,2001 \text {, or receiving services from a } \\
\text { community service provider accredited or certified by the Department of Human Services, which is located } \\
\text { within a community safety zone; } \\
\text { (3) The person was under age eighteen at the time of the offense and the offender was not tried and convicted } \\
\text { of the offense as an adult; } \\
\text { (4) The person established the residence prior to July } 1 \text {, West } 2008 \text {; } \\
\text { (5) The school, public park, public pool, or public playground was built or established subsequent to the } \\
\text { person's establishing residence at the location; or } \\
\text { (6) The circuit court has entered an order pursuant to } \S 22-24 B-28 \text { exempting the offender from the provisions } \\
\text { of } \S \S 22-24 B-22 \text { to } 22-24 B-28 \text {, inclusive. } \\
\text { S.D.C.L. } \S 22-24 B-24 \\
\text { Sex offenders also may not loiter in a community safety zone unless the offender was under } 18 \text { at the time of the } \\
\text { offense. }\end{array}$ \\
\hline
\end{tabular}

** Denotes those states where sex offender registration is required for convictions under the staff sexual misconduct laws of the states. Staff and inmates could also be required to register as sex offenders if the offense were charged under other registrable offenses.

This publication is developed by the NIC/WCL Project on Addressing Prison Rape under NIC Cooperative Agreement 06S20GJJ1.

This is not to be posted or reproduced without permission from the authors.

American University, Washington College of Law

Current as of August 2009 


\section{Fifty State Survey of Adult Sex Offender Registration Requirements}

\section{NIC/WCL Project on Addressing Prison Rape}

\begin{tabular}{|c|c|}
\hline $\begin{array}{l}\text { Duration of Registration } \\
\text { (South Dakota) }\end{array}$ & $\begin{array}{l}\text { S.D.C.L. } \S 22-24 B-19 \text { (West 2008) } \\
\text { (1) An offender may petition for removal from the sex offender registry after } 10 \text { years have elapsed } \\
\text { (2) if: } \\
\text { (a) The registrable offense was statutory rape and the offender was } 21 \text { years of age or younger; } \\
\text { (b) The offense was a juvenile adjudication for a sex crime; } \\
\text { (3) The crime did not involve a child under the age of } 13 \text {; } \\
\text { (4) The petitioner is not a repeat sex offender; } \\
\text { (5) The offender has completely complied with registration. }\end{array}$ \\
\hline & TENNESSEE*** \\
\hline $\begin{array}{l}\text { Registrable Offenses } \\
\text { (Tennessee) }\end{array}$ & 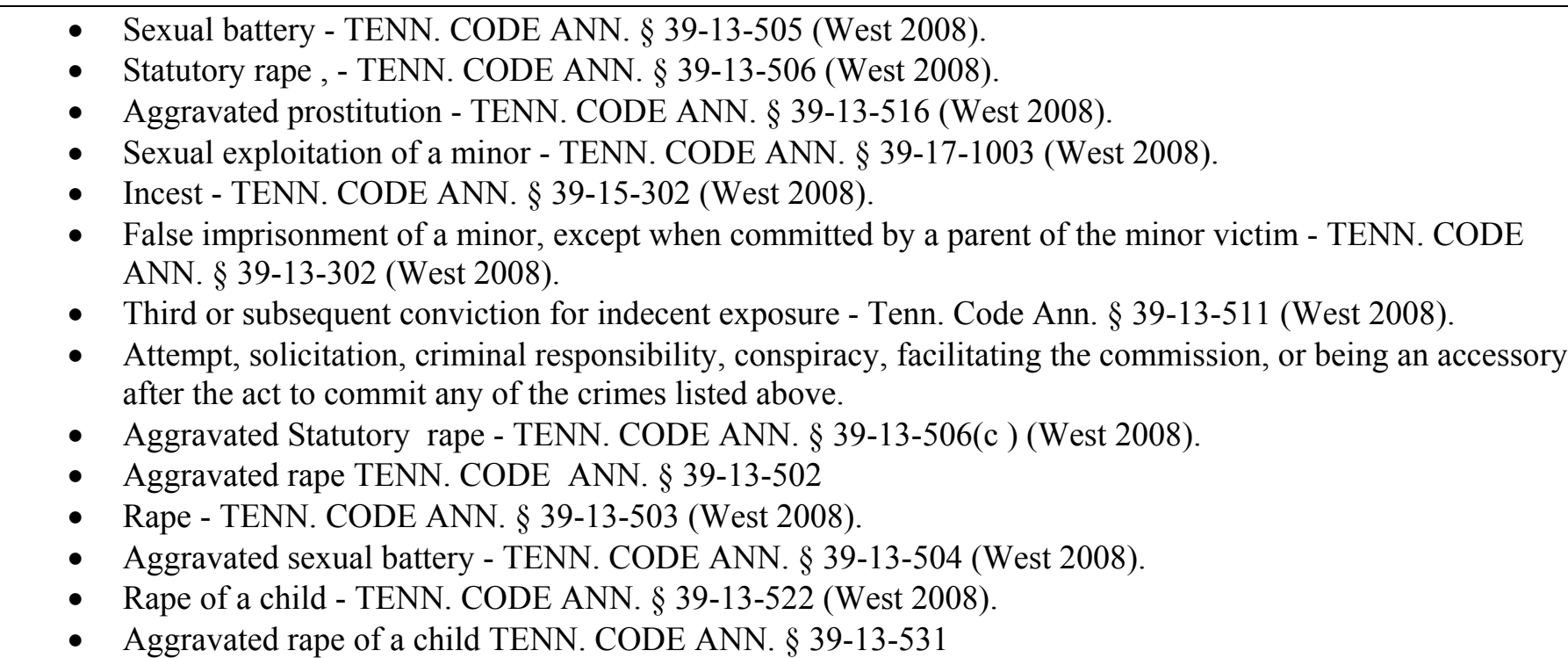 \\
\hline
\end{tabular}

** Denotes those states where sex offender registration is required for convictions under the staff sexual misconduct laws of the states. Staff and 200 inmates could also be required to register as sex offenders if the offense were charged under other registrable offenses.

This publication is developed by the NIC/WCL Project on Addressing Prison Rape under NIC Cooperative Agreement 06S20GJJ1.

This is not to be posted or reproduced without permission from the authors.

American University, Washington College of Law

Current as of August 2009 


\section{Fifty State Survey of Adult Sex Offender Registration Requirements}

\section{NIC/WCL Project on Addressing Prison Rape}

\begin{tabular}{|c|c|}
\hline $\begin{array}{l}\text { Registrable Offenses Cont'd } \\
\text { (Tennessee) }\end{array}$ & 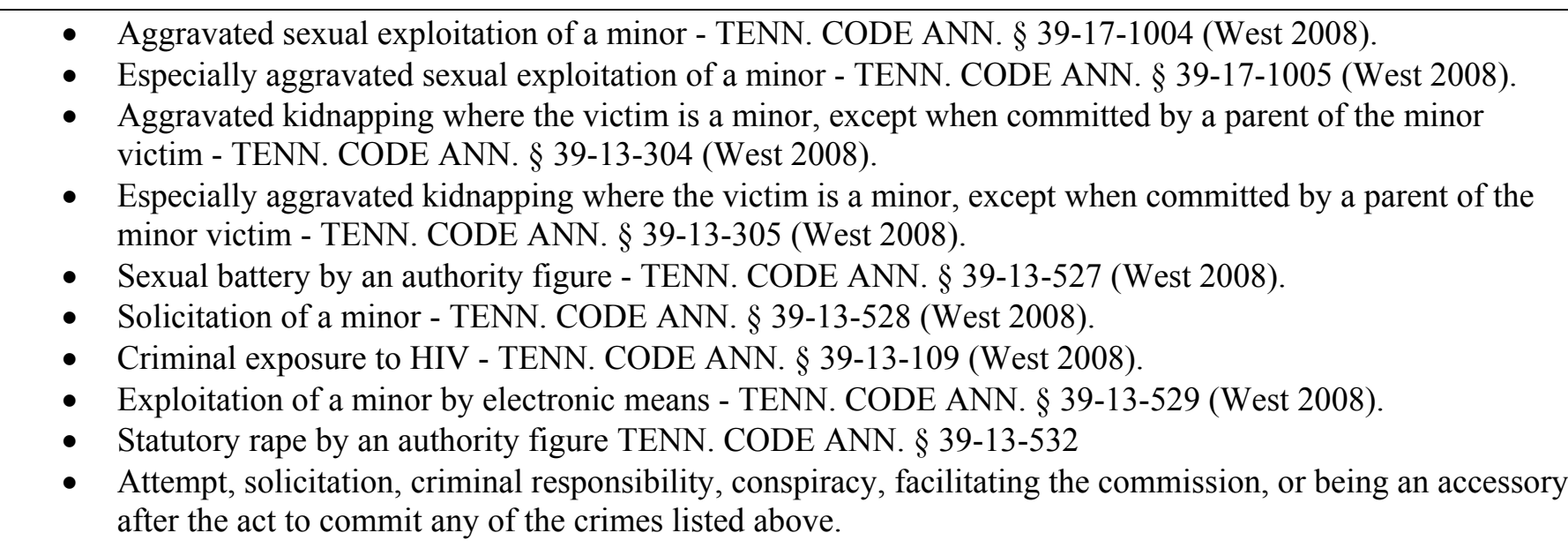 \\
\hline $\begin{array}{l}\text { Sex Offender Registration } \\
\text { Required for Staff Sexual } \\
\text { Misconduct? } \\
\text { (Tennessee) }\end{array}$ & $\begin{array}{l}\text { YES. } \\
\text { T.C.A. } \$ 39-13-527 \text { (West 2008) } \\
\text { (a) Sexual battery by an authority figure is unlawful sexual contact with a victim by the defendant or the defendant } \\
\text { by a victim accompanied by the following circumstances: } \\
\text { (1) The victim was, at the time of the offense, thirteen (13) years of age or older but less then eighteen (18) } \\
\text { years of age; or } \\
\text { (2) The victim was, at the time of the offense, mentally defective, mentally incapacitated or physically } \\
\text { helpless, regardless of age; and, } \\
\text { (3)(A) The defendant was at the time of the offense in a position of trust, or had supervisory or disciplinary } \\
\text { power over the victim by virtue of the defendant's legal, professional or occupational status and used the }\end{array}$ \\
\hline
\end{tabular}

** Denotes those states where sex offender registration is required for convictions under the staff sexual misconduct laws of the states. Staff and 201 inmates could also be required to register as sex offenders if the offense were charged under other registrable offenses.

This publication is developed by the NIC/WCL Project on Addressing Prison Rape under NIC Cooperative Agreement 06S20GJJ1.

This is not to be posted or reproduced without permission from the authors.

American University, Washington College of Law

Current as of August 2009 


\section{Fifty State Survey of Adult Sex Offender Registration Requirements}

\section{NIC/WCL Project on Addressing Prison Rape}

\begin{tabular}{|c|c|}
\hline $\begin{array}{l}\text { Sex Offender Registration } \\
\text { Required for Staff Sexual } \\
\text { Misconduct? Cont'd } \\
\text { (Tennessee) }\end{array}$ & $\begin{array}{l}\text { position of trust or power to accomplish the sexual contact; or } \\
\text { (3)(B) The defendant had, at the time of the offense, parental or custodial authority over the victim and used } \\
\text { the authority to accomplish the sexual contact. } \\
\text { (b) Sexual battery by an authority figure is a Class C felony. }\end{array}$ \\
\hline $\begin{array}{l}\text { Information Maintained in } \\
\text { Sex Offender Registry } \\
\text { (Tennessee) }\end{array}$ & $\begin{array}{l}\text { TENN. CODE ANN. } \S 40-39-203 \text { (West 2008) } \\
\text { (i) TBI registration forms shall require the registrant's signature and disclosure of the following information, under } \\
\text { penalty of perjury, pursuant to } \S 39-16-702(\text { b) }(3) \text { : } \\
\text { (1) Complete name and all aliases, including, but not limited to, any names that the offender may have had } \\
\text { or currently has by reason of marriage or otherwise; } \\
\text { (2) Date and place of birth; } \\
\text { (3) Social security number; } \\
\text { (4) A photocopy of a valid driver's license, or if no valid driver license has been issued to the offender, a } \\
\text { photocopy of any state or federal government issued identification card; } \\
\text { (5) For an offender on supervised release, the name, address, and telephone number of the registrant's } \\
\text { probation or parole officer or other person responsible for the registrant's supervision; } \\
\text { (6) Sexual offenses or violent sexual offenses for which the registrant has been convicted, the date of the } \\
\text { offenses and the county and state of each conviction; } \\
\text { (7) Name of any current employers and length of employment, including physical addresses and phone } \\
\text { numbers; }\end{array}$ \\
\hline
\end{tabular}

** Denotes those states where sex offender registration is required for convictions under the staff sexual misconduct laws of the states. Staff and inmates could also be required to register as sex offenders if the offense were charged under other registrable offenses.

This publication is developed by the NIC/WCL Project on Addressing Prison Rape under NIC Cooperative Agreement 06S20GJJ1.

This is not to be posted or reproduced without permission from the authors.

American University, Washington College of Law

Current as of August 2009 


\section{Fifty State Survey of Adult Sex Offender Registration Requirements}

\section{NIC/WCL Project on Addressing Prison Rape}

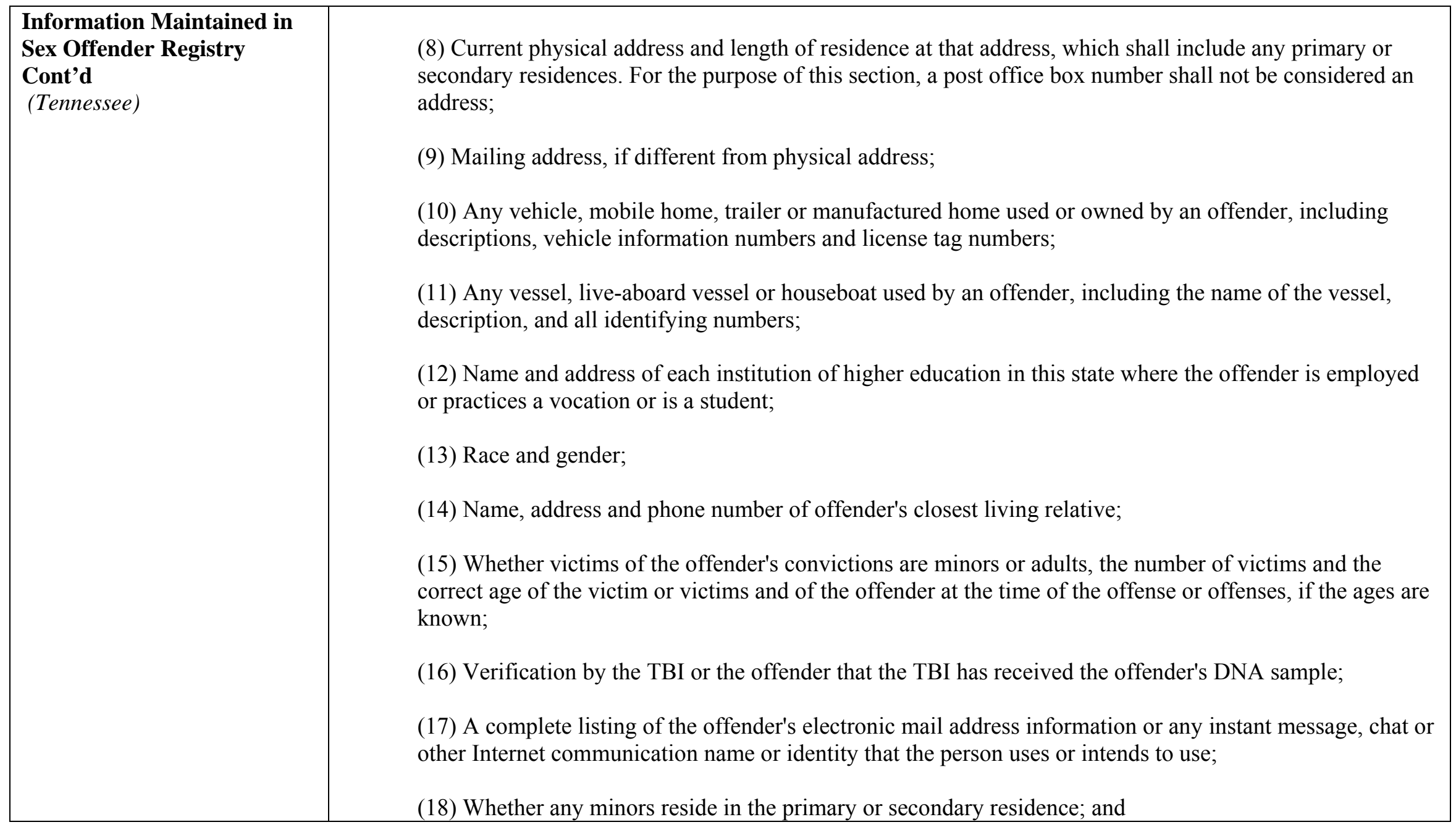

** Denotes those states where sex offender registration is required for convictions under the staff sexual misconduct laws of the states. Staff and inmates could also be required to register as sex offenders if the offense were charged under other registrable offenses.

This publication is developed by the NIC/WCL Project on Addressing Prison Rape under NIC Cooperative Agreement 06S20GJJ1.

This is not to be posted or reproduced without permission from the authors.

American University, Washington College of Law

Current as of August 2009 


\section{Fifty State Survey of Adult Sex Offender Registration Requirements}

\section{NIC/WCL Project on Addressing Prison Rape}

\begin{tabular}{|c|c|}
\hline $\begin{array}{l}\text { Information Maintained in } \\
\text { Sex Offender Registry } \\
\text { Cont'd } \\
\text { (Tennessee) }\end{array}$ & $\begin{array}{l}\text { (19)(A) Any other registration, verification and tracking information, including fingerprints and a current } \\
\text { photograph of the offender, vehicles and vessels, as referred to in subdivisions (i)(10) and (i)(11), as may be } \\
\text { required by rules promulgated by the TBI, in accordance with the Uniform Administrative Procedures Act, } \\
\text { compiled in title } 4 \text {, chapter } 5 \text {; }\end{array}$ \\
\hline $\begin{array}{l}\text { Community Notification } \\
\text { and Websites } \\
\text { (Tennessee) }\end{array}$ & $\begin{array}{l}\text { T.C.A. } \S 40-39-206 \text { (West 2008) } \\
\text { (e): } \\
\text { - For all sexual offenses, and offenses now defined as violent sexual offenses, committed on or after July 1, 1997, } \\
\text { the information concerning a registered offender shall be considered public information. } \\
\text { - In addition to making the information available in the same manner as public records, the Tennessee Bureau of } \\
\text { Investigations (TBI) shall prepare and place the information on the state's Internet homepage. } \\
\text { - This information shall become a part of the Tennessee internet criminal information center when that center is } \\
\text { created within the TBI. } \\
\text { - The TBI shall also establish and operate a toll-free telephone number, to be known as the "Tennessee Internet } \\
\text { Criminal Information Center Hotline," to permit members of the public to call and inquire as to whether a named } \\
\text { individual is listed among those who have registered as offenders as required by this part. }\end{array}$ \\
\hline $\begin{array}{l}\text { Limitations on Residency or } \\
\text { Employment } \\
\text { (Tennessee) }\end{array}$ & $\begin{array}{l}\text { TENN. CODE ANN. } \S 40-39-211 \text { (West } 2008 \text { ) } \\
\text { (a) While mandated to comply with the requirements of this chapter, no sexual offender, as defined in } \S 40-39-202 \text {, } \\
\text { or violent sexual offender, as defined in } \S 40-39-202 \text {, whose victim was a minor, shall knowingly establish a } \\
\text { primary or secondary residence or any other living accommodation, knowingly obtain sexual offender treatment or } \\
\text { attend a sexual offender treatment program or knowingly accept employment within one thousand feet }\left(1,000^{\prime}\right) \text { of } \\
\text { the property line of any public school, private or parochial school, licensed day care center, other child care facility, } \\
\text { public park, playground, recreation center or public athletic field available for use by the general public. }\end{array}$ \\
\hline
\end{tabular}

** Denotes those states where sex offender registration is required for convictions under the staff sexual misconduct laws of the states. Staff and 204 inmates could also be required to register as sex offenders if the offense were charged under other registrable offenses.

This publication is developed by the NIC/WCL Project on Addressing Prison Rape under NIC Cooperative Agreement 06S20GJJ1.

This is not to be posted or reproduced without permission from the authors.

American University, Washington College of Law

Current as of August 2009 


\section{Fifty State Survey of Adult Sex Offender Registration Requirements}

\section{NIC/WCL Project on Addressing Prison Rape}

\begin{tabular}{|c|c|}
\hline $\begin{array}{l}\text { Limitations on Residency or } \\
\text { Employment Cont'd } \\
\text { (Tennessee) }\end{array}$ & 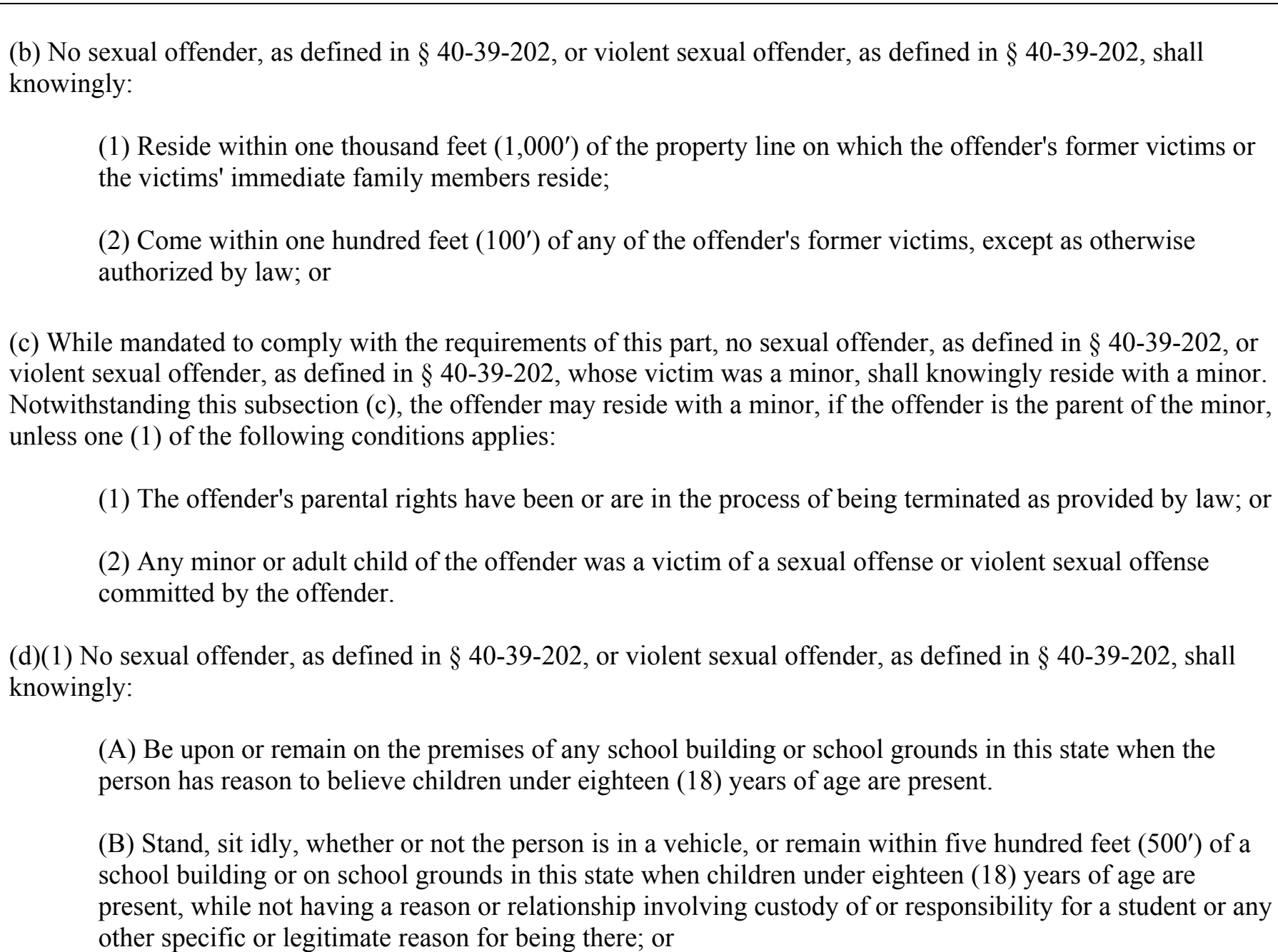 \\
\hline
\end{tabular}

** Denotes those states where sex offender registration is required for convictions under the staff sexual misconduct laws of the states. Staff and inmates could also be required to register as sex offenders if the offense were charged under other registrable offenses.

This publication is developed by the NIC/WCL Project on Addressing Prison Rape under NIC Cooperative Agreement 06S20GJJ1.

This is not to be posted or reproduced without permission from the authors.

American University, Washington College of Law

Current as of August 2009 


\section{Fifty State Survey of Adult Sex Offender Registration Requirements}

\section{NIC/WCL Project on Addressing Prison Rape}

\begin{tabular}{|c|c|}
\hline $\begin{array}{l}\text { Limitations on Residency or } \\
\text { Employment Cont'd } \\
\text { (Tennessee) }\end{array}$ & 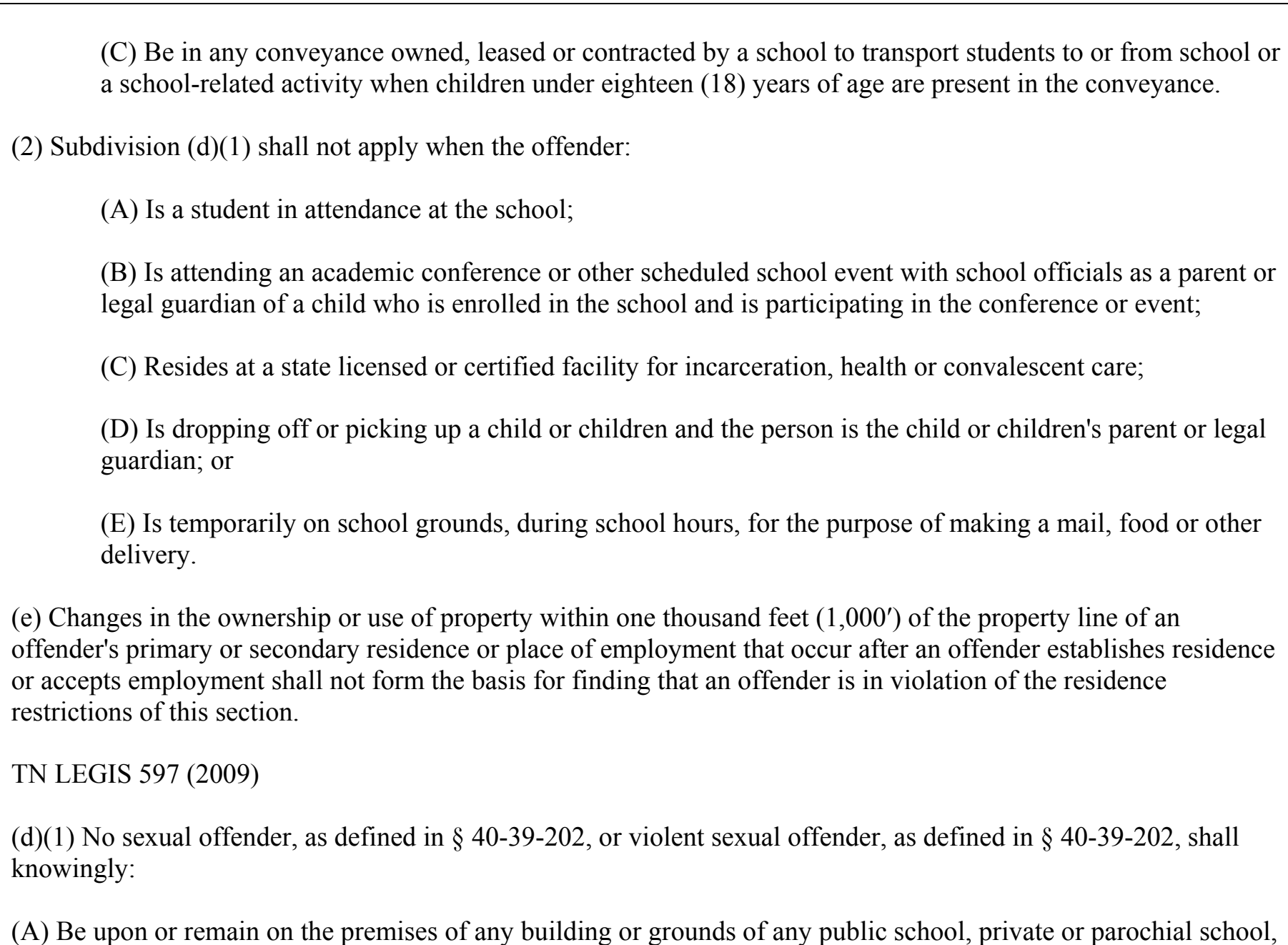 \\
\hline
\end{tabular}

** Denotes those states where sex offender registration is required for convictions under the staff sexual misconduct laws of the states. Staff and 206 inmates could also be required to register as sex offenders if the offense were charged under other registrable offenses.

This publication is developed by the NIC/WCL Project on Addressing Prison Rape under NIC Cooperative Agreement 06S20GJJ1.

This is not to be posted or reproduced without permission from the authors.

American University, Washington College of Law

Current as of August 2009 


\section{Fifty State Survey of Adult Sex Offender Registration Requirements}

\section{NIC/WCL Project on Addressing Prison Rape}

\begin{tabular}{|c|c|}
\hline $\begin{array}{l}\text { Limitations on Residency or } \\
\text { Employment Cont'd } \\
\text { (Tennessee) }\end{array}$ & 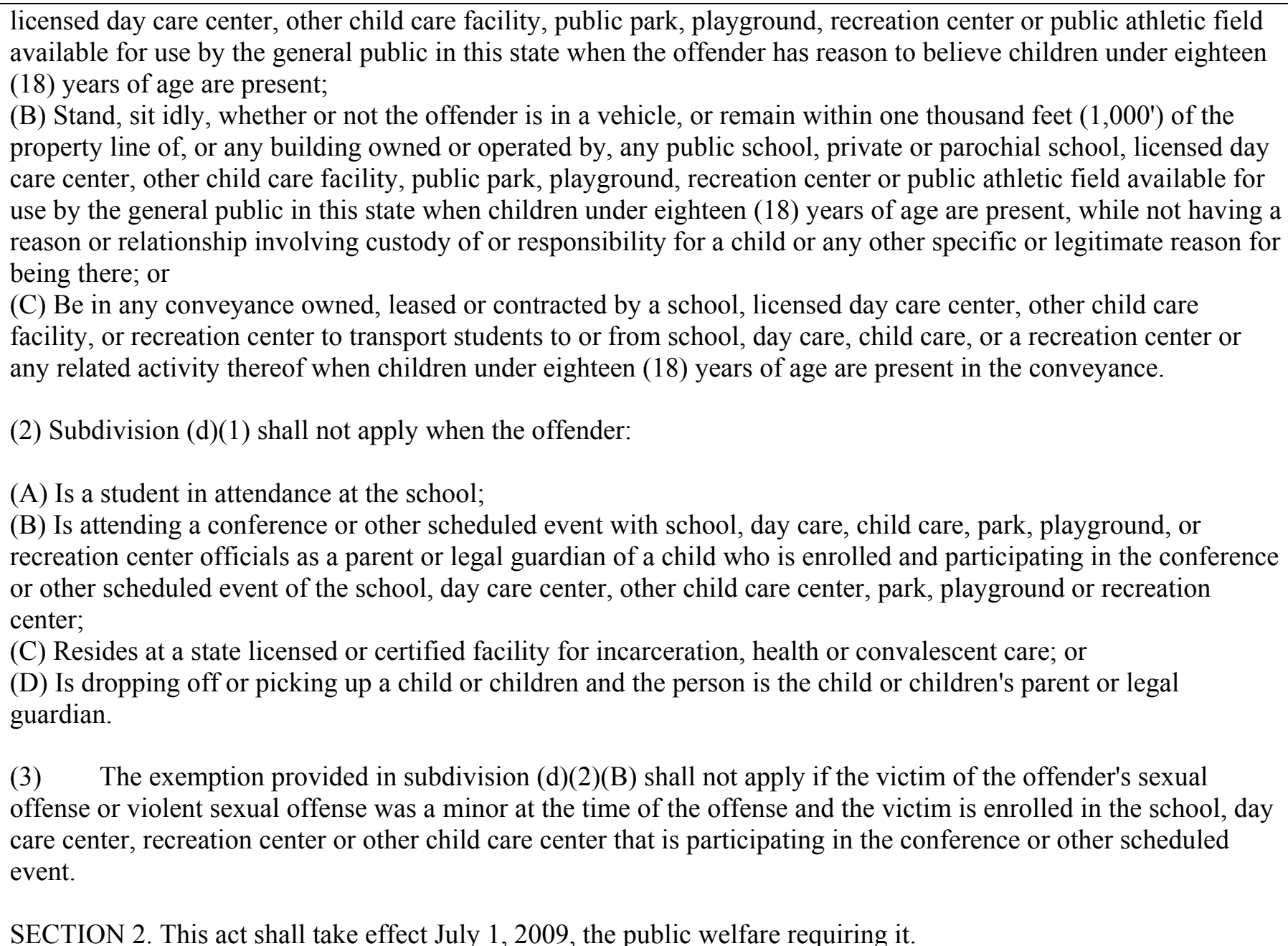 \\
\hline
\end{tabular}

** Denotes those states where sex offender registration is required for convictions under the staff sexual misconduct laws of the states. Staff and inmates could also be required to register as sex offenders if the offense were charged under other registrable offenses.

This publication is developed by the NIC/WCL Project on Addressing Prison Rape under NIC Cooperative Agreement 06S20GJJ1.

This is not to be posted or reproduced without permission from the authors.

American University, Washington College of Law

Current as of August 2009 


\section{Fifty State Survey of Adult Sex Offender Registration Requirements}

\section{NIC/WCL Project on Addressing Prison Rape}

\begin{tabular}{|c|c|}
\hline $\begin{array}{l}\text { Duration of Registration } \\
\text { (Tennessee) }\end{array}$ & $\begin{array}{l}\text { T.C.A. } \$ 40-39-207 \text { (West 2008) } \\
\text { (a)(1) Sex offenders may petition for termination of the registration obligation no sooner than } 10 \text { years since their } \\
\text { release from incarceration. } \\
\text { (g)(1) Life for persons: } \\
\text { - With } 1 \text { or more prior sex offense convictions } \\
\text { - Who have been convicted of a violent sexual offense. }\end{array}$ \\
\hline & TEXAS \\
\hline $\begin{array}{l}\text { Registrable Offenses } \\
\text { (Texas) }\end{array}$ & 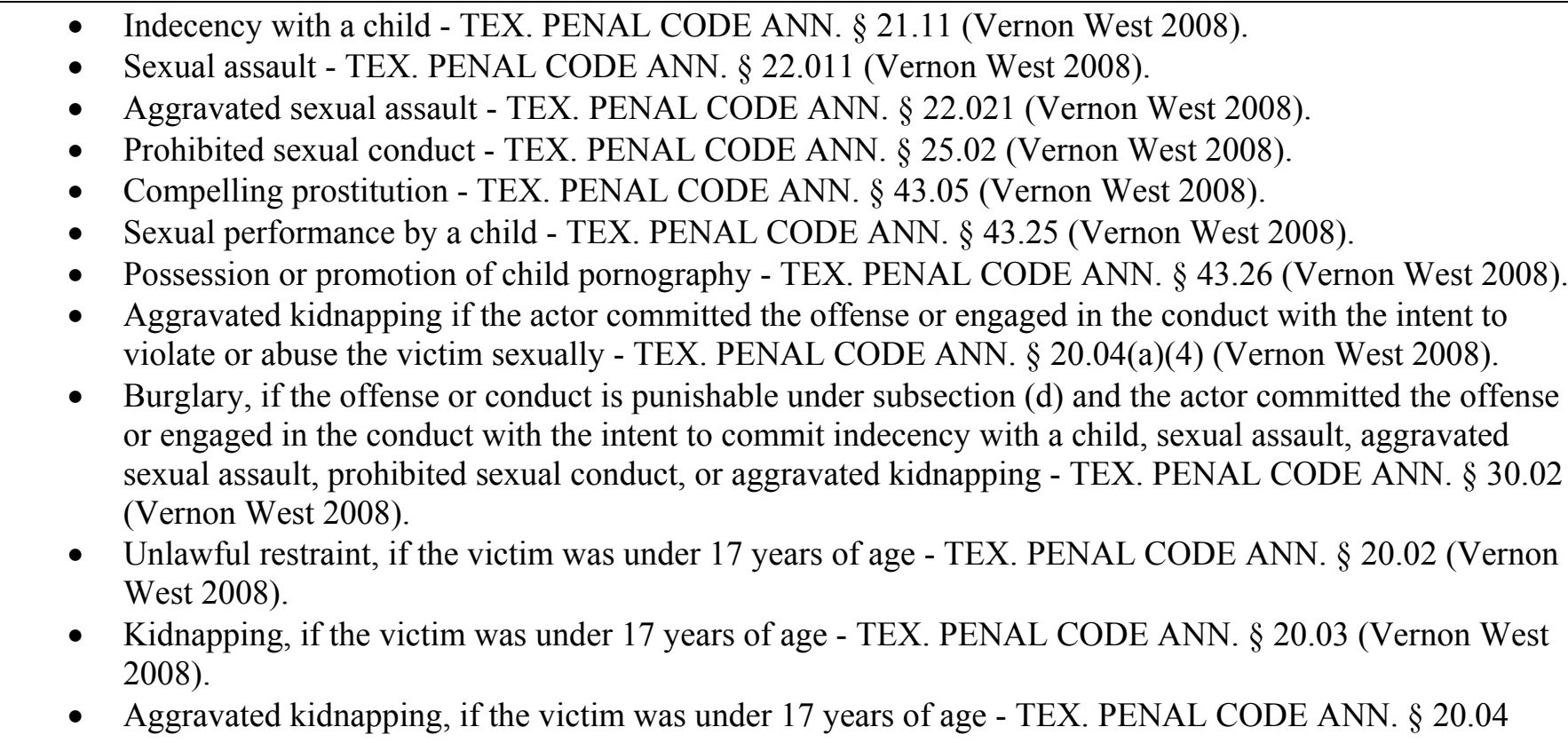 \\
\hline
\end{tabular}

** Denotes those states where sex offender registration is required for convictions under the staff sexual misconduct laws of the states. Staff and 208 inmates could also be required to register as sex offenders if the offense were charged under other registrable offenses.

This publication is developed by the NIC/WCL Project on Addressing Prison Rape under NIC Cooperative Agreement 06S20GJJ1.

This is not to be posted or reproduced without permission from the authors.

American University, Washington College of Law

Current as of August 2009 


\section{Fifty State Survey of Adult Sex Offender Registration Requirements}

\section{NIC/WCL Project on Addressing Prison Rape}

\begin{tabular}{|c|c|}
\hline $\begin{array}{l}\text { Registrable Offenses Cont'd } \\
\text { (Texas) }\end{array}$ & $\begin{array}{l}\text { (Vernon West 2008). } \\
\text { - Second violation for indecent exposure, unless the second violation results in a deferred adjudication - } \\
\text { TEX. PENAL CODE ANN. } \S 21.08 \text { (Vernon West 2008). } \\
\text { - Attempt, conspiracy or solicitation to commit an offense or engage in conduct listed above. } \\
\text { A violation of the laws of another state, federal law, the laws of a foreign country, or the Uniform Code of } \\
\text { Military Justice for or based on the violation of an offense containing elements that are substantially similar to the } \\
\text { elements of an offense listed above. }\end{array}$ \\
\hline $\begin{array}{l}\text { Sex Offender Registration } \\
\text { Required for Staff Sexual } \\
\text { Misconduct? } \\
\text { (Texas) }\end{array}$ & NO \\
\hline $\begin{array}{l}\text { Information Maintained in } \\
\text { Sex Offender Registry } \\
\text { (Texas) }\end{array}$ & $\begin{array}{l}\text { TX. CRIM. PRO. ART. } 62.051 \text { (West 2008) } \\
\text { (c) The registration form shall require: } \\
\text { (1) the person's full name, each alias, date of birth, sex, race, height, weight, eye color, hair color, social security } \\
\text { number, driver's license number, shoe size, and home address; } \\
\text { (2) a recent color photograph or, if possible, an electronic digital image of the person and a complete set of the } \\
\text { person's fingerprints; } \\
\text { (3) the type of offense the person was convicted of, the age of the victim, the date of conviction, and the } \\
\text { punishment received; } \\
\text { (4) an indication as to whether the person is discharged, paroled, or released on juvenile probation, community } \\
\text { supervision, or mandatory supervision; } \\
\text { (5) an indication of each license, as defined by Article } 62.005(\mathrm{~g}) \text {, that is held or sought by the person; } \\
\text { (6) an indication as to whether the person is or will be employed, carrying on a vocation, or a student at a } \\
\text { particular public or private institution of higher education in this state or another state, and the name and } \\
\text { address of that institution; and }\end{array}$ \\
\hline
\end{tabular}

** Denotes those states where sex offender registration is required for convictions under the staff sexual misconduct laws of the states. Staff and inmates could also be required to register as sex offenders if the offense were charged under other registrable offenses.

This publication is developed by the NIC/WCL Project on Addressing Prison Rape under NIC Cooperative Agreement 06S20GJJ1.

This is not to be posted or reproduced without permission from the authors.

American University, Washington College of Law

Current as of August 2009 


\section{Fifty State Survey of Adult Sex Offender Registration Requirements}

\section{NIC/WCL Project on Addressing Prison Rape}

\begin{tabular}{|c|c|}
\hline $\begin{array}{l}\text { Information Maintained in } \\
\text { Sex Offender Registry } \\
\text { Cont'd } \\
\text { (Texas) }\end{array}$ & (7) any other information required by the department. \\
\hline $\begin{array}{l}\text { Community Notification } \\
\text { and Websites } \\
\text { (Texas) }\end{array}$ & $\begin{array}{l}\text { TX. CRIM. PRO. ART. } 62.056 \text { (West 2008) } \\
\text { (d) On receipt of notice under this chapter that a person subject to registration under this chapter is required to } \\
\text { register or verify registration with a local law enforcement authority and has been assigned a numeric risk level of } \\
\text { three, the local law enforcement authority may provide notice to the public in any manner determined appropriate } \\
\text { by the local law enforcement authority, including: } \\
\text { - Publishing notice in a newspaper or other periodical or } \\
\text { - Circular in circulation in the area where the person intends to reside, } \\
\text { - Holding a neighborhood meeting, } \\
\text { - Posting notices in the area where the person intends to reside, } \\
\text { - Distributing printed notices to area residents, or } \\
\text { - Establishing a specialized local website. } \\
\text { The local law enforcement authority may include in the notice only information that is public information under this } \\
\text { chapter. }\end{array}$ \\
\hline $\begin{array}{l}\text { Limitations on Residency or } \\
\text { Employment } \\
\text { (Texas) }\end{array}$ & None \\
\hline $\begin{array}{l}\text { Duration of Registration } \\
\text { (Texas) }\end{array}$ & $\begin{array}{l}\text { TX. CRIM. PRO. ART. } 62.101 \text { (West 2008) } \\
\text { (5)(b) } 10 \text { years for offenders not subject to lifetime registration. }\end{array}$ \\
\hline
\end{tabular}

** Denotes those states where sex offender registration is required for convictions under the staff sexual misconduct laws of the states. Staff and 210 inmates could also be required to register as sex offenders if the offense were charged under other registrable offenses.

This publication is developed by the NIC/WCL Project on Addressing Prison Rape under NIC Cooperative Agreement 06S20GJJ1.

This is not to be posted or reproduced without permission from the authors.

American University, Washington College of Law

Current as of August 2009 


\section{Fifty State Survey of Adult Sex Offender Registration Requirements}

\section{NIC/WCL Project on Addressing Prison Rape}

\begin{tabular}{|c|c|}
\hline $\begin{array}{l}\text { Duration of Registration } \\
\text { Cont'd } \\
\text { (Texas) }\end{array}$ & $\begin{array}{l}\text { Life for persons with a reportable conviction for: } \\
\text { - A sexually violent offense; } \\
\text { - Prohibited sexual conduct; } \\
\text { - Compelling prostitution; } \\
\text { - Possession or promotion of child pornography; } \\
\text { - Indecency with a child, if the person has prior or subsequent convictions for a registrable offense; } \\
\text { - Unlawful restraint, kidnapping or aggravated kidnapping of a victim under } 17 \text { and the offender has prior or } \\
\text { subsequent convictions for a registrable offense; } \\
\text { - Child pornography depicting a minor. }\end{array}$ \\
\hline & UTAH \\
\hline $\begin{array}{l}\text { Registrable Offenses } \\
\text { (Utah) }\end{array}$ & 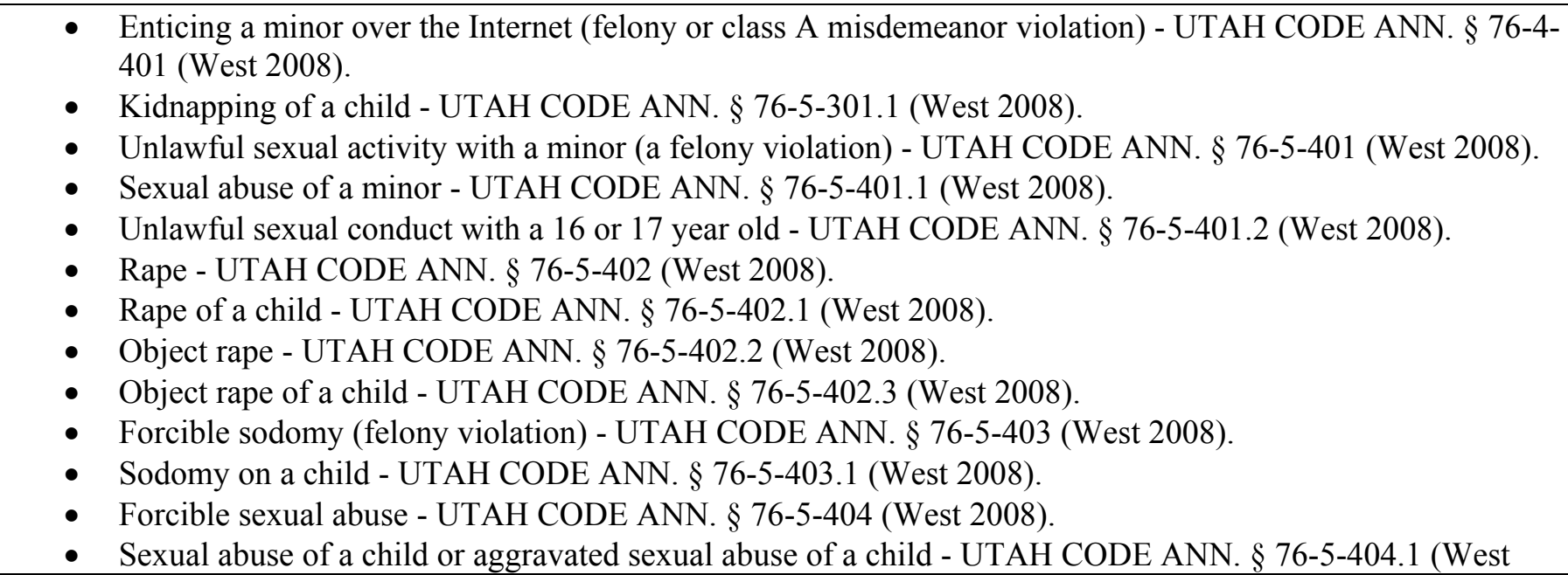 \\
\hline
\end{tabular}

** Denotes those states where sex offender registration is required for convictions under the staff sexual misconduct laws of the states. Staff and 211 inmates could also be required to register as sex offenders if the offense were charged under other registrable offenses.

This publication is developed by the NIC/WCL Project on Addressing Prison Rape under NIC Cooperative Agreement 06S20GJJ1.

This is not to be posted or reproduced without permission from the authors.

American University, Washington College of Law

Current as of August 2009 


\section{Fifty State Survey of Adult Sex Offender Registration Requirements}

\section{NIC/WCL Project on Addressing Prison Rape}

\begin{tabular}{|c|c|}
\hline $\begin{array}{l}\text { Registrable Offenses Cont'd } \\
\text { (Utah) }\end{array}$ & 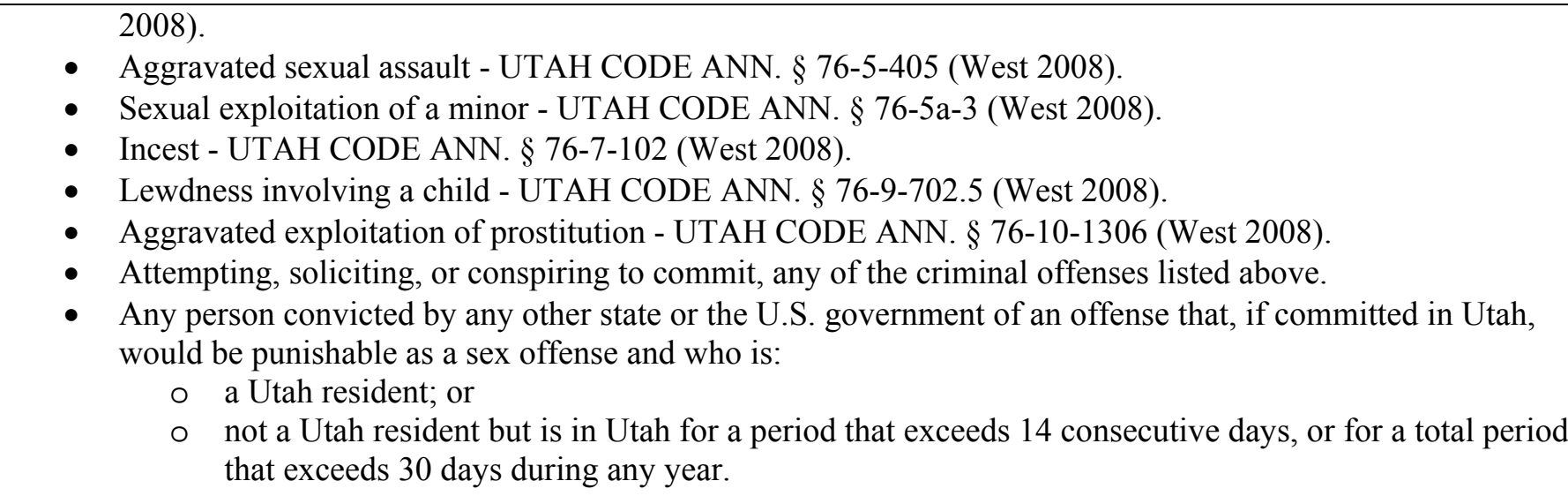 \\
\hline $\begin{array}{l}\text { Sex Offender Registration } \\
\text { Required for Staff Sexual } \\
\text { Misconduct? } \\
\text { (Utah) }\end{array}$ & NO \\
\hline $\begin{array}{l}\text { Information Maintained in } \\
\text { Sex Offender Registry } \\
\text { (Utah) }\end{array}$ & $\begin{array}{l}\text { U.C.A. } \$ 77-27-21.5 \text { (West 2008) } \\
\text { (12) An offender shall provide the department or the registering entity with the following information: } \\
\text { (a) all names and aliases by which the offender is or has been known; } \\
\text { (b) the addresses of the offender's primary and secondary residences; } \\
\text { (c) a physical description, including the offender's date of birth, height, weight, eye and hair color; } \\
\text { (d) the make, model, color, year, plate number, and vehicle identification number of any vehicle or vehicles the } \\
\text { (e) a current photograph of the offender; } \\
\text { (f) a set of fingerprints, if one has not already been provided; } \\
\text { (g) a DNA specimen, taken in accordance with Section 53-10-404, if one has not already been provided; }\end{array}$ \\
\hline
\end{tabular}

** Denotes those states where sex offender registration is required for convictions under the staff sexual misconduct laws of the states. Staff and inmates could also be required to register as sex offenders if the offense were charged under other registrable offenses.

This publication is developed by the NIC/WCL Project on Addressing Prison Rape under NIC Cooperative Agreement 06S20GJJ1.

This is not to be posted or reproduced without permission from the authors.

American University, Washington College of Law

Current as of August 2009 


\section{Fifty State Survey of Adult Sex Offender Registration Requirements}

\section{NIC/WCL Project on Addressing Prison Rape}

\begin{tabular}{|c|c|}
\hline $\begin{array}{l}\text { Information Maintained in } \\
\text { Sex Offender Registry } \\
\text { Cont'd } \\
\text { (Utah) }\end{array}$ & $\begin{array}{l}\text { (h) telephone numbers and any other designations used by the offender for routing or self-identification in } \\
\text { telephonic communications from fixed locations or cellular telephones } \\
\text { (i) Internet identifiers and the addresses the offender uses for routing or self-identification in Internet } \\
\text { communications or postings; } \\
\text { (j) the name and Internet address of all websites on which the sex offender is registered using an online } \\
\text { identifier, including all online identifiers and passwords used to access those websites; } \\
\text { (k) a copy of the offender's passport, if a passport has been issued to the offender; } \\
\text { (l) if the offender is an alien, all documents establishing the offender's immigration status; } \\
\text { (m) all professional licenses that authorize the offender to engage in an occupation or carry out a trade or } \\
\text { business, including any identifiers, such as numbers; } \\
\text { (n) each educational institution in Utah at which the offender is employed, carries on a vocation, or is a student, } \\
\text { and any change of enrollment or employment status of the offender at any educational institution; } \\
\text { (o) the name and the address of any place where the offender is employed or will be employed; } \\
\text { (p) the name and the address of any place where the offender works as a volunteer or will work as a volunteer; } \\
\text { and } \\
\text { (q) the offender's Social Security number. }\end{array}$ \\
\hline $\begin{array}{l}\text { Community Notification } \\
\text { and Websites } \\
\text { (Utah) }\end{array}$ & $\begin{array}{l}\text { U.C.A. } § 7-27-21.5 \text { (West 2008) } \\
\text { (15) Information collected and released under this section is public information. } \\
\text { (22) The department shall post registry information on the Internet. }\end{array}$ \\
\hline $\begin{array}{l}\text { Limitations on Residency or } \\
\text { Employment } \\
\text { (Utah) }\end{array}$ & None. \\
\hline $\begin{array}{l}\text { Duration of Registration } \\
\text { (Utah) }\end{array}$ & $\begin{array}{l}\text { U.C.A. } § 77-27-21.5 \text { (West 2008) } \\
\text { (9) } 10 \text { years for offenders not subject to lifetime registration. }\end{array}$ \\
\hline
\end{tabular}

** Denotes those states where sex offender registration is required for convictions under the staff sexual misconduct laws of the states. Staff and inmates could also be required to register as sex offenders if the offense were charged under other registrable offenses.

This publication is developed by the NIC/WCL Project on Addressing Prison Rape under NIC Cooperative Agreement 06S20GJJ1.

This is not to be posted or reproduced without permission from the authors.

American University, Washington College of Law

Current as of August 2009 


\section{Fifty State Survey of Adult Sex Offender Registration Requirements}

\section{NIC/WCL Project on Addressing Prison Rape}

\begin{tabular}{|c|c|}
\hline $\begin{array}{l}\text { Duration of Registration } \\
\text { Cont'd } \\
\text { (Utah) }\end{array}$ & $\begin{array}{l}\text { (c)(i)(a) Life for persons convicted of: } \\
\text { - Rape of a child } \\
\text { - Object rape of a child } \\
\text { - Forcible sodomy } \\
\text { - Sodomy on a child } \\
\text { - Aggravated sexual assault } \\
\text { - Any registrable offense, if the offender has previously been convicted of a registrable offense. }\end{array}$ \\
\hline & VERMONT \\
\hline $\begin{array}{l}\text { Registrable Offenses } \\
\text { (Vermont) }\end{array}$ & 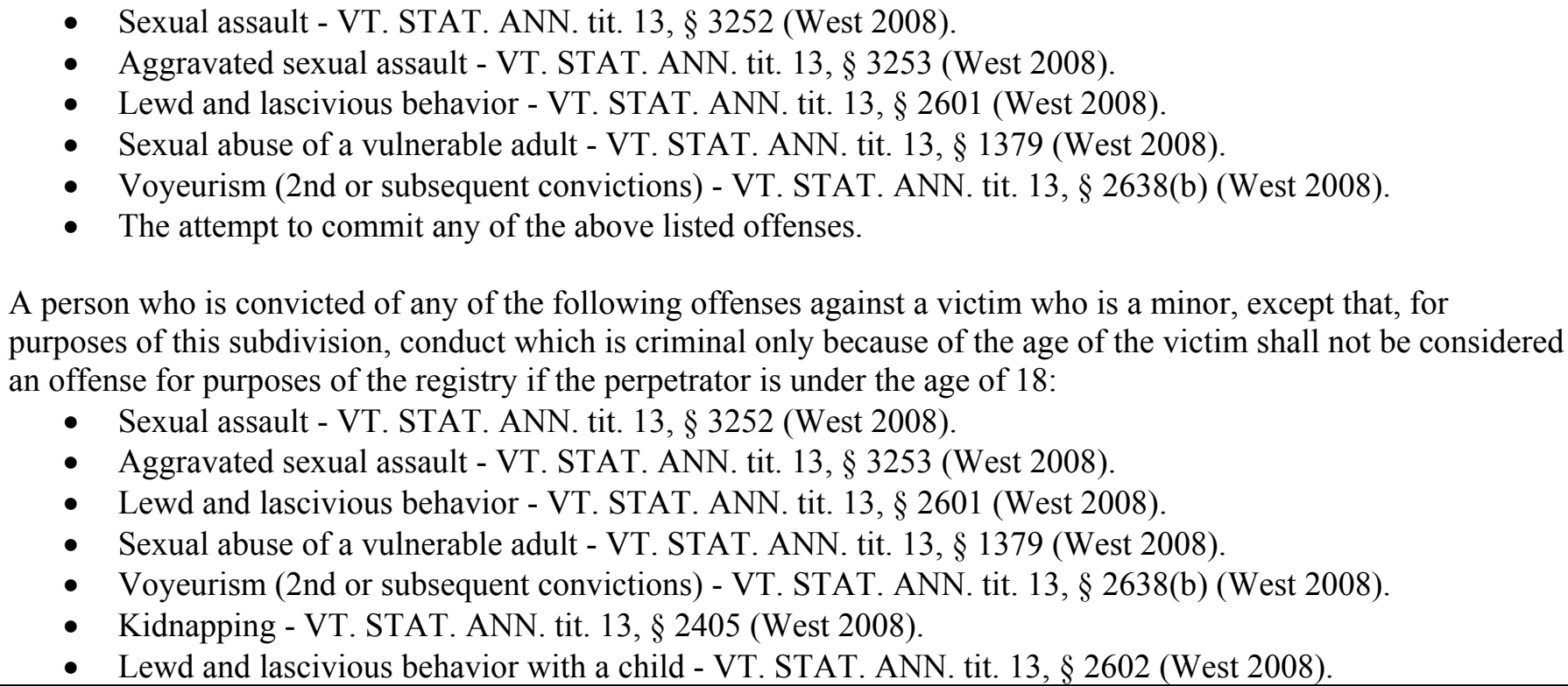 \\
\hline
\end{tabular}

** Denotes those states where sex offender registration is required for convictions under the staff sexual misconduct laws of the states. Staff and 214 inmates could also be required to register as sex offenders if the offense were charged under other registrable offenses.

This publication is developed by the NIC/WCL Project on Addressing Prison Rape under NIC Cooperative Agreement 06S20GJJ1.

This is not to be posted or reproduced without permission from the authors.

American University, Washington College of Law

Current as of August 2009 


\section{Fifty State Survey of Adult Sex Offender Registration Requirements}

\section{NIC/WCL Project on Addressing Prison Rape}

\begin{tabular}{|c|c|}
\hline $\begin{array}{l}\text { Registrable Offenses Cont'd } \\
\text { (Vermont) }\end{array}$ & $\begin{array}{l}\text { - White slave traffic - VT. STAT. ANN. tit. 13, } \S 2635 \text { (West 2008). } \\
\text { - } \quad \text { Sexual exploitation of children - VT. STAT. ANN. tit. 13, } \S 2821-2828 \text { (West 2008). } \\
\text { - } \quad \text { The attempt to commit any of the above listed offenses. } \\
\text { - A person who takes up residence in Vermont, other than within a correctional facility, and who has been } \\
\text { convicted in any jurisdiction of the United States for a sex crime, the elements of which would constitute an } \\
\text { offense listed in (1) or (2) above if committed in Vermont. } \\
\text { - A nonresident sex offender who crosses into Vermont and who is employed, carries on a vocation, or is a } \\
\text { student. }\end{array}$ \\
\hline $\begin{array}{l}\text { Sex Offender Registration } \\
\text { Required for Staff Sexual } \\
\text { Misconduct? } \\
\text { (Vermont) }\end{array}$ & NO \\
\hline $\begin{array}{l}\text { Information Maintained in } \\
\text { Sex Offender Registry } \\
\text { (Vermont) }\end{array}$ & $\begin{array}{l}13 \text { V.S.A. } \S 5403 \text { (West 2008) } \\
\text { (a) Upon conviction and prior to sentencing, the court shall order the sex offender to provide the court with the } \\
\text { following information, which the court shall forward to the department forthwith: } \\
\text { (1) name; } \\
\text { (2) date of birth; } \\
\text { (3) general physical description; } \\
\text { (4) current address; } \\
\text { (5) Social Security number; } \\
\text { (6) fingerprints; } \\
\text { (7) current photograph; } \\
\text { (8) current employment; and } \\
\text { (9) name and address of any postsecondary educational institution at which the sex offender is enrolled as a } \\
\end{array}$ \\
\hline
\end{tabular}

** Denotes those states where sex offender registration is required for convictions under the staff sexual misconduct laws of the states. Staff and inmates could also be required to register as sex offenders if the offense were charged under other registrable offenses.

This publication is developed by the NIC/WCL Project on Addressing Prison Rape under NIC Cooperative Agreement 06S20GJJ1.

This is not to be posted or reproduced without permission from the authors.

American University, Washington College of Law

Current as of August 2009 


\section{Fifty State Survey of Adult Sex Offender Registration Requirements}

\section{NIC/WCL Project on Addressing Prison Rape}

\begin{tabular}{|c|c|}
\hline $\begin{array}{l}\text { Community Notification } \\
\text { and Websites } \\
\text { (Vermont) }\end{array}$ & $\begin{array}{l}\text { 13 V.S.A. } \S \S 5411 \text { (West 2008) } \\
\text { (b)(1) The department, the department of corrections, and any authorized local law enforcement agency shall } \\
\text { release registry information concerning persons required to register under state law if the requestor can articulate a } \\
\text { concern about the behavior of a specific person regarding the requestor's personal safety or the safety of another, or } \\
\text { the requestor has reason to believe that a specific person may be a registered sex offender and can articulate a } \\
\text { concern regarding the requestor's personal safety or the safety of another. } \\
\text { (c) (1) Except as provided for in subsection (e) of this section, upon request of a member of the public about a } \\
\text { specific person, the department, the department of corrections, and any authorized local law enforcement agency } \\
\text { shall release registry information on sex offenders whose information is required to be posted on the internet. } \\
13 \text { V.S.A. } \S 5411 \text { a (West } 2008 \text { ) } \\
\text { The department shall electronically post information on the internet regarding the following sex offenders, upon } \\
\text { their release from confinement: } \\
\text { (8) Sex offenders who have been convicted of a aggravated sexual assault, lewd or lascivious conduct with child } \\
\text { if the offender has been designated as high risk by the department of corrections or kidnapping and sexual } \\
\text { assault of a child } \\
\text { (9) Sex offenders who have at least one prior conviction for an offense described in subdivision 5401(10) of this } \\
\text { subchapter. } \\
\text { (10) Sex offenders who have failed to comply with sex offender registration requirements and for whose arrest } \\
\text { there is an outstanding warrant for such noncompliance. Information on offenders shall remain on the } \\
\text { internet only while the warrant is outstanding. } \\
\text { (11) Sex offenders who have been designated as sexual predators. } \\
\text { (12) Sex offenders who have not complied with sex offender treatment recommended by the department of } \\
\text { corrections or who are ineligible for sex offender treatment. } \\
\text { (13) Sex offenders who have been designated by the department of corrections as high-risk. }\end{array}$ \\
\hline
\end{tabular}

** Denotes those states where sex offender registration is required for convictions under the staff sexual misconduct laws of the states. Staff and inmates could also be required to register as sex offenders if the offense were charged under other registrable offenses.

This publication is developed by the NIC/WCL Project on Addressing Prison Rape under NIC Cooperative Agreement 06S20GJJ1.

This is not to be posted or reproduced without permission from the authors.

American University, Washington College of Law

Current as of August 2009 


\section{Fifty State Survey of Adult Sex Offender Registration Requirements}

\section{NIC/WCL Project on Addressing Prison Rape}

\begin{tabular}{|c|c|}
\hline $\begin{array}{l}\text { Limitations on Residency or } \\
\text { Employment } \\
\text { (Vermont) }\end{array}$ & None \\
\hline $\begin{array}{l}\text { Duration of Registration } \\
\text { (Vermont) }\end{array}$ & $\begin{array}{l}13 \text { V.S.A. } \S 5407(\mathrm{e})-(\mathrm{f})(\text { West } 2008) \\
10 \text { years for persons not subject to lifetime registration. } \\
\text { Life for persons: } \\
\text { - With at least } 1 \text { prior conviction or a registrable offense } \\
\text { - Convicted of sexual assault when the victim was under } 14 \text { and the offender was more than } 6 \text { years older than the } \\
\text { victim } \\
\text { - Convicted of aggravated sexual assault } \\
\text { - Determined to be a sexually violent predator. }\end{array}$ \\
\hline
\end{tabular}

** Denotes those states where sex offender registration is required for convictions under the staff sexual misconduct laws of the states. Staff and inmates could also be required to register as sex offenders if the offense were charged under other registrable offenses.

This publication is developed by the NIC/WCL Project on Addressing Prison Rape under NIC Cooperative Agreement 06S20GJJ1.

This is not to be posted or reproduced without permission from the authors.

American University, Washington College of Law

Current as of August 2009 


\section{Fifty State Survey of Adult Sex Offender Registration Requirements}

\section{NIC/WCL Project on Addressing Prison Rape}

\begin{tabular}{|c|c|}
\hline $\begin{array}{l}\text { Registrable Offenses Cont'd } \\
\text { (Virgin Islands) }\end{array}$ & $\begin{array}{l}\text { commit rape as described in } 14 \text { V.I.C. } \$ \S 1052(\mathrm{~b}), 1700,1701 \text { and } 1708 \text { (West 2008); or an offense similar to any } \\
\text { of the foregoing offenses proscribed under the laws of the United States or any other state, territory or country. }\end{array}$ \\
\hline $\begin{array}{l}\text { Sex Offender Registration } \\
\text { Required for Staff Sexual } \\
\text { Misconduct? }^{4} \\
\text { (Virgin Islands) }^{\text {(Ving }}\end{array}$ & NO \\
\hline $\begin{array}{l}\text { Information Maintained in } \\
\text { Sex Offender Registry } \\
\text { (Virgin Islands) }\end{array}$ & $\begin{array}{l}\text { 14 V.I.C. } \$ 1726 \text { (West 2008) } \\
\text { (1) } \\
\text { - name } \\
\text { - social security number } \\
\text { - age } \\
\text { - race } \\
\text { - sex } \\
\text { - date of birth } \\
\text { - height and weight } \\
\text { - hair and eye color } \\
\text { - address of legal residence } \\
\text { - address of any current temporary residence and anticipated future residence } \\
\text { - date and place of employment } \\
\text { - date and place of each conviction or acquittal by reason of insanity } \\
\text { - indictment number } \\
\text { - fingerprints } \\
\text { - photograph } \\
\text { - a brief description of the crime for which registration is required }\end{array}$ \\
\hline
\end{tabular}

** Denotes those states where sex offender registration is required for convictions under the staff sexual misconduct laws of the states. Staff and inmates could also be required to register as sex offenders if the offense were charged under other registrable offenses.

This publication is developed by the NIC/WCL Project on Addressing Prison Rape under NIC Cooperative Agreement 06S20GJJ1.

This is not to be posted or reproduced without permission from the authors.

American University, Washington College of Law

Current as of August 2009 


\section{Fifty State Survey of Adult Sex Offender Registration Requirements}

\section{NIC/WCL Project on Addressing Prison Rape}

\begin{tabular}{|c|c|}
\hline $\begin{array}{l}\text { Community Notification } \\
\text { and Websites } \\
\text { (Virgin Islands) }\end{array}$ & $\begin{array}{l}14 \text { V.I.C. } \$ 1727 \text { (West 2008) } \\
\text { (a) Records maintained pursuant to this chapter shall be open to any law enforcement agency for law enforcement } \\
\text { purposes, and to government agencies conducting confidential background checks. } \\
\text { (b) The Attorney General shall release to the public relevant and necessary information regarding a specific person } \\
\text { required to register under this chapter when the release of the information is necessary for public protection; except } \\
\text { that the identity of a victim of an offense whose perpetrator is required to register under this chapter shall not be } \\
\text { released. } \\
\text { (c) Nothing in this section shall be construed to prevent law enforcement officers from notifying members of the } \\
\text { public exposed to danger of any persons who pose a danger under circumstances that are not enumerated in this } \\
\text { chapter. } \\
\text { (d) The Attorney General shall notify the owner of a child-care facility whenever a person who is required to } \\
\text { register under this chapter lives within a one-mile radius of that child-care facility. }\end{array}$ \\
\hline $\begin{array}{l}\text { Duration of Registration } \\
\text { (Virgin Islands) }\end{array}$ & $\begin{array}{l}14 \text { V.I.C. } \S 1724 \text { (West 2008) } \\
\text { (e) } 15 \text { years since initial registration date, if not imprisoned during that period. } \\
\text { Any person imprisoned during the initial fifteen-year period, shall continue to comply with this chapter for a period }\end{array}$ \\
\hline
\end{tabular}

** Denotes those states where sex offender registration is required for convictions under the staff sexual misconduct laws of the states. Staff and 219 inmates could also be required to register as sex offenders if the offense were charged under other registrable offenses.

This publication is developed by the NIC/WCL Project on Addressing Prison Rape under NIC Cooperative Agreement 06S20GJJ1.

This is not to be posted or reproduced without permission from the authors.

American University, Washington College of Law

Current as of August 2009 


\section{Fifty State Survey of Adult Sex Offender Registration Requirements}

\section{NIC/WCL Project on Addressing Prison Rape}

\begin{tabular}{|c|c|}
\hline $\begin{array}{l}\text { Duration of Registration } \\
\text { Cont'd } \\
\text { (Virgin Islands) }\end{array}$ & $\begin{array}{l}\text { of } 15 \text { years after his last release from prison, regardless of the crime for which he was imprisoned. } \\
\text { (f) Life if the person: } \\
\text { - Has } 2 \text { or more convictions or has been found not guilty by reason of insanity of a criminal offense against a } \\
\text { minor; or } \\
\text { - Has been convicted of or found not guilty by reason of insanity for a sexually violent offense or as a sexually } \\
\text { violent predator. }\end{array}$ \\
\hline & VIRGINIA** \\
\hline $\begin{array}{l}\text { Registrable Offenses } \\
\text { (Virginia) }\end{array}$ & 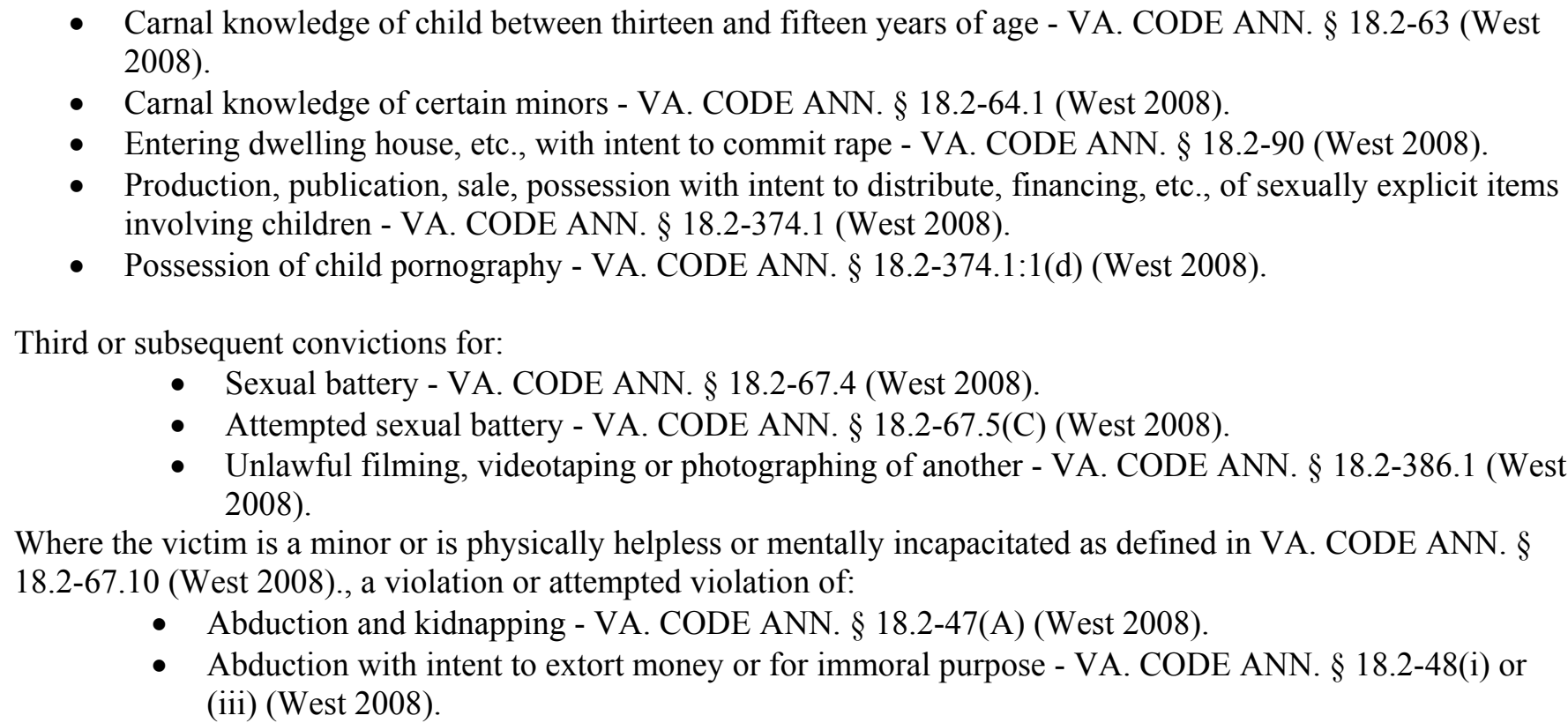 \\
\hline
\end{tabular}

** Denotes those states where sex offender registration is required for convictions under the staff sexual misconduct laws of the states. Staff and 220 inmates could also be required to register as sex offenders if the offense were charged under other registrable offenses.

This publication is developed by the NIC/WCL Project on Addressing Prison Rape under NIC Cooperative Agreement 06S20GJJ1.

This is not to be posted or reproduced without permission from the authors.

American University, Washington College of Law

Current as of August 2009 


\section{Fifty State Survey of Adult Sex Offender Registration Requirements}

\section{NIC/WCL Project on Addressing Prison Rape}

\begin{tabular}{|c|c|}
\hline $\begin{array}{l}\text { Registrable Offenses Cont'd } \\
\text { (Virginia) }\end{array}$ & 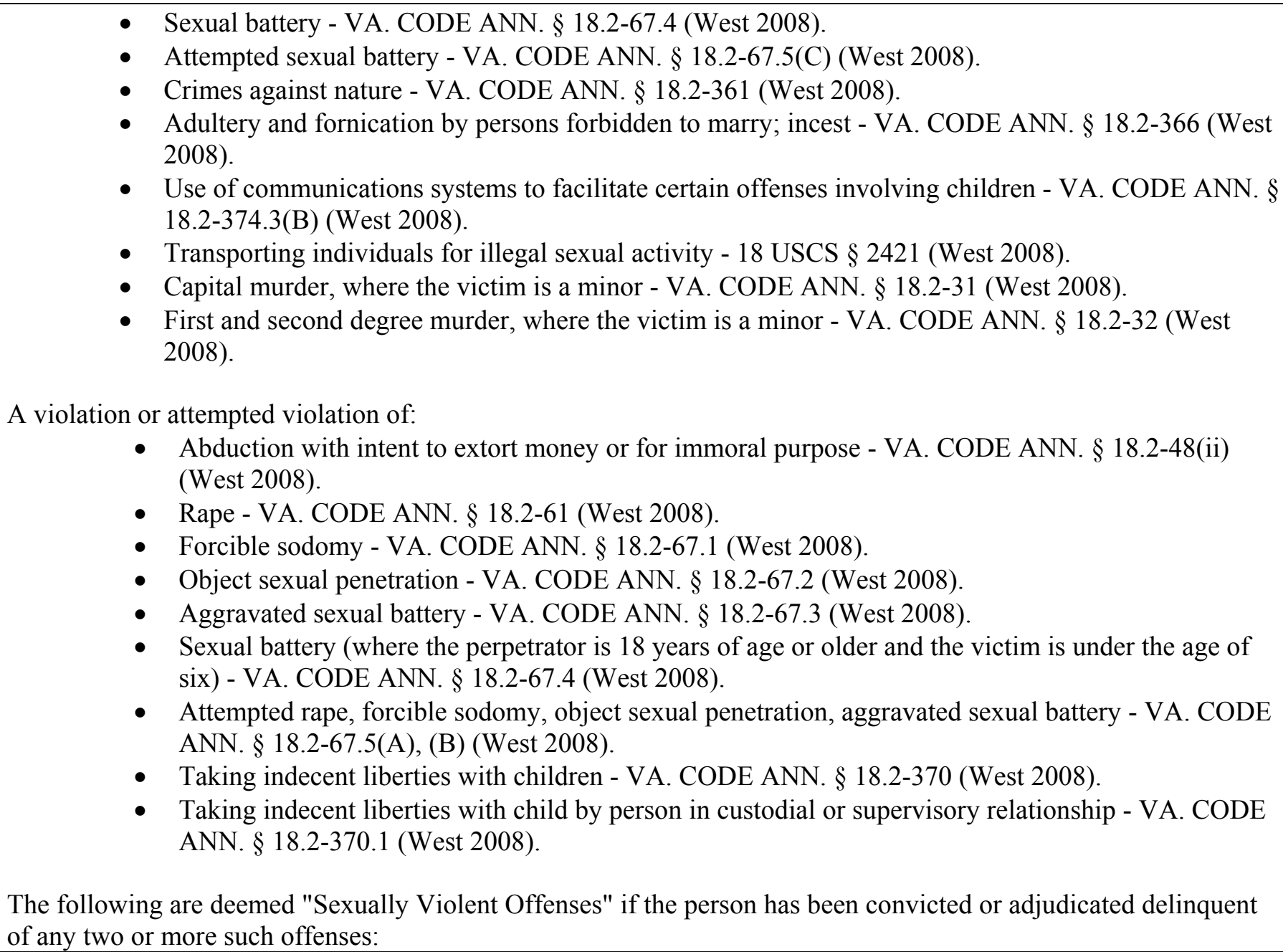 \\
\hline
\end{tabular}

** Denotes those states where sex offender registration is required for convictions under the staff sexual misconduct laws of the states. Staff and 221 inmates could also be required to register as sex offenders if the offense were charged under other registrable offenses.

This publication is developed by the NIC/WCL Project on Addressing Prison Rape under NIC Cooperative Agreement 06S20GJJ1.

This is not to be posted or reproduced without permission from the authors.

American University, Washington College of Law

Current as of August 2009 


\section{Fifty State Survey of Adult Sex Offender Registration Requirements}

\section{NIC/WCL Project on Addressing Prison Rape}

\begin{tabular}{|c|c|}
\hline $\begin{array}{l}\text { Registrable Offenses Cont'd } \\
\text { (Virginia) }\end{array}$ & $\begin{array}{l}\text { - Abduction and kidnapping - VA. CODE ANN. } \S 18.2-47(\mathrm{~A}) \text { (West 2008). } \\
\text { - Abduction with intent to extort money or for immoral purpose - VA. CODE ANN. } \S 18.2-48(\mathrm{i}) \text { or (iii) } \\
\text { - Crimest 2008). } \\
\text { - Attempted sexual battery - VA. CODE ANN. } \S 18.2-67.5(\mathrm{C}) \text { (West 2008). } \\
\text { - Adultery and fornication by persons forbidden to marry; incest - VA. CODE ANN. } \S 18.2-366 \text { (West } \\
\text { 2008). } \\
\text { Production, publication, sale, possession with intent to distribute, financing, etc., of sexually explicit items } \\
\text { involving children - VA. CODE ANN. } \S 18.2-374.1 \text { (West 2008). } \\
\text { Any similar offense under the laws of the United States or any political subdivision thereof and any offense } \\
\text { for which registration in a sex offender and crimes against minors registry is required under the laws of the } \\
\text { political subdivision where the offender was convicted. }\end{array}$ \\
\hline $\begin{array}{l}\text { Sex Offender Registration } \\
\text { Required for Staff Sexual } \\
\text { Misconduct? } \\
\text { (Virginia) }\end{array}$ & $\begin{array}{l}\text { YES } \\
\text { VA. CODE ANN. } \S 18.2-64.1 \text { (West 2008) } \\
\text { If any person providing services, paid or unpaid, to juveniles under the purview of the Juvenile and Domestic } \\
\text { Relations District Court Law, or to juveniles who have been committed to the custody of the State Department of } \\
\text { Juvenile Justice, carnally knows, without the use of force, any minor fifteen years of age or older, when such minor } \\
\text { is confined or detained in jail, is detained in any facility mentioned in } \S 16.1-249 \text {, or has been committed to the } \\
\text { custody of the Department of Juvenile Justice pursuant to } \S 16.1-278.8 \text {, knowing or having good reason to believe } \\
\text { that (i) such minor is in such confinement or detention status, (ii) such minor is a ward of the Department of } \\
\text { Juvenile Justice, or (iii) such minor is on probation, furlough, or leave from or has escaped or absconded from such } \\
\text { confinement, detention, or custody, he shall be guilty of a Class } 6 \text { felony. }\end{array}$ \\
\hline $\begin{array}{l}\text { Information Maintained in } \\
\text { Sex Offender Registry } \\
\text { (Virginia) }\end{array}$ & $\begin{array}{l}\text { VA. CODE ANN. } \$ 9.1-903(\text { West 2008) } \\
\text { (H) } \\
\quad \text { name }\end{array}$ \\
\hline
\end{tabular}

** Denotes those states where sex offender registration is required for convictions under the staff sexual misconduct laws of the states. Staff and inmates could also be required to register as sex offenders if the offense were charged under other registrable offenses.

This publication is developed by the NIC/WCL Project on Addressing Prison Rape under NIC Cooperative Agreement 06S20GJJ1.

This is not to be posted or reproduced without permission from the authors.

American University, Washington College of Law

Current as of August 2009 


\section{Fifty State Survey of Adult Sex Offender Registration Requirements}

\section{NIC/WCL Project on Addressing Prison Rape}

\begin{tabular}{|c|c|}
\hline $\begin{array}{l}\text { Information Maintained in } \\
\text { Sex Offender Registry } \\
\text { Cont'd } \\
\text { (Virginia) }\end{array}$ & $\begin{array}{l}\text { - all aliases } \\
\text { - date and locality of the conviction for which registration is required } \\
\text { - fingerprints } \\
\text { - photograph } \\
\text { - date of birth } \\
\text { - social security number } \\
\text { - current physical and mailing address } \\
\text { - description of the offense(s) for which he/she was convicted }\end{array}$ \\
\hline $\begin{array}{l}\text { Community Notification } \\
\text { and Websites } \\
\text { (Virginia) }\end{array}$ & $\begin{array}{l}\text { VA. CODE ANN. } \$ 9.1-912 \text { (West 2008) } \\
\text { (A) } \\
\text { - Registry information shall be disseminated upon request made directly to the State Police or to the State Police } \\
\text { through a local law-enforcement agency. } \\
\text { - Such information may be disclosed to any person requesting information on a specific individual in accordance } \\
\text { with subsection B. } \\
\text { - The State Police shall make Registry information available, upon request, to criminal justice agencies including } \\
\text { local law-enforcement agencies through the Virginia Criminal Information Network (VCIN). } \\
\text { - Registry information provided under this section shall be used for the purposes of the administration of criminal } \\
\text { justice, for the screening of current or prospective employees or volunteers or otherwise for the protection of the } \\
\text { public in general and children in particular. } \\
\text { VA. CoDE ANN. } § 9.1-913 \text { (West } 2008 \text { ) } \\
\text { - The State Police shall develop and maintain a system for making certain Registry information on persons } \\
\text { convicted of an offense for which registration is required publicly available by means of the Internet. }\end{array}$ \\
\hline
\end{tabular}

** Denotes those states where sex offender registration is required for convictions under the staff sexual misconduct laws of the states. Staff and 223 inmates could also be required to register as sex offenders if the offense were charged under other registrable offenses.

This publication is developed by the NIC/WCL Project on Addressing Prison Rape under NIC Cooperative Agreement 06S20GJJ1.

This is not to be posted or reproduced without permission from the authors.

American University, Washington College of Law

Current as of August 2009 


\section{Fifty State Survey of Adult Sex Offender Registration Requirements}

\section{NIC/WCL Project on Addressing Prison Rape}

\begin{tabular}{|c|c|}
\hline $\begin{array}{l}\text { Community Notification } \\
\text { and Websites Cont'd } \\
\text { (Virginia) }\end{array}$ & 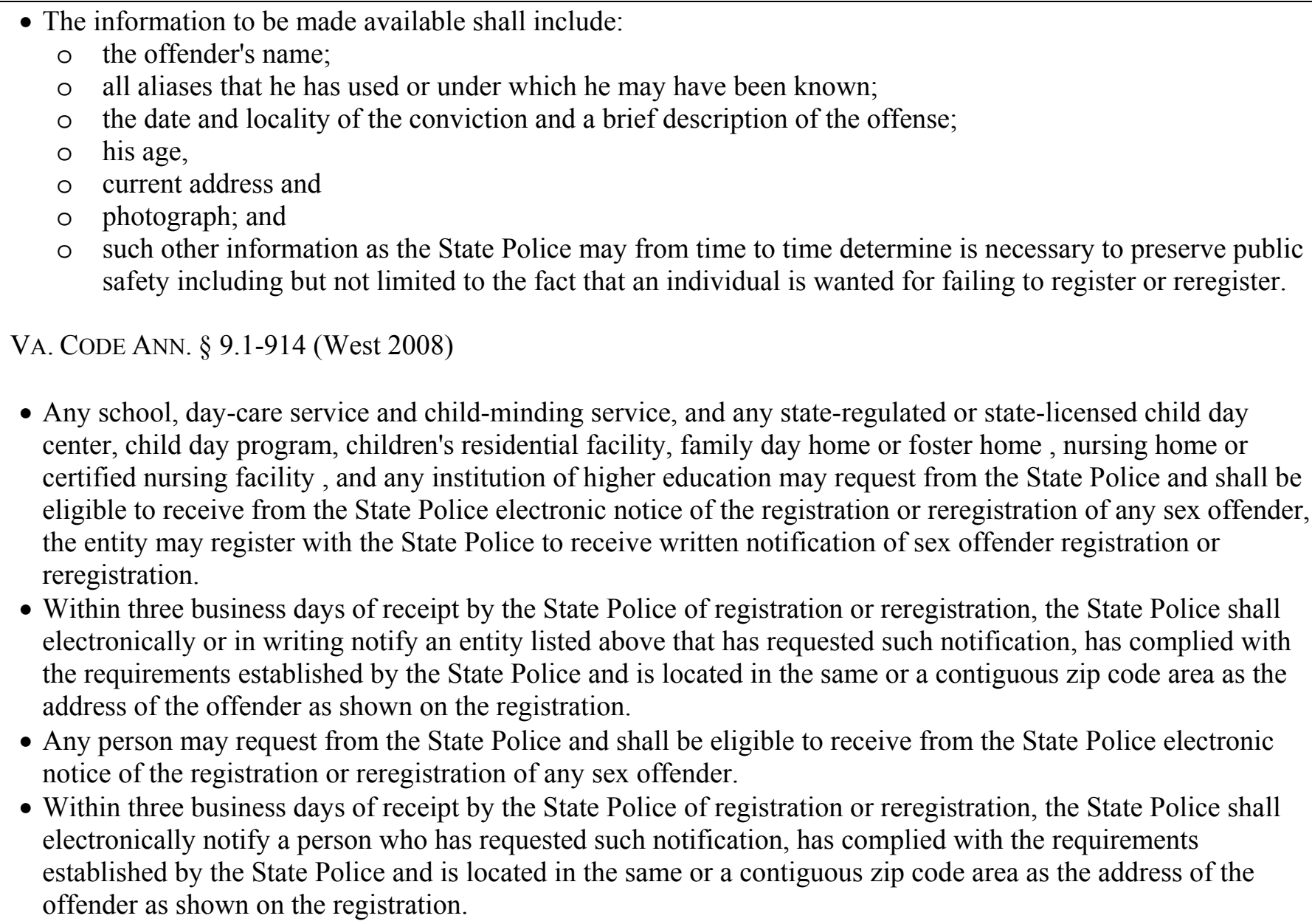 \\
\hline
\end{tabular}

** Denotes those states where sex offender registration is required for convictions under the staff sexual misconduct laws of the states. Staff and inmates could also be required to register as sex offenders if the offense were charged under other registrable offenses.

This publication is developed by the NIC/WCL Project on Addressing Prison Rape under NIC Cooperative Agreement 06S20GJJ1.

This is not to be posted or reproduced without permission from the authors.

American University, Washington College of Law

Current as of August 2009 


\section{Fifty State Survey of Adult Sex Offender Registration Requirements}

\section{NIC/WCL Project on Addressing Prison Rape}

\begin{tabular}{|l|l|}
\hline $\begin{array}{l}\text { Limitations on Residency or } \\
\text { Employment } \\
\text { (Virginia) }\end{array}$ & None \\
\hline $\begin{array}{l}\text { Duration of Registration } \\
\text { (Virginia) }\end{array}$ & $\begin{array}{l}\text { VA. CODE ANN. § 9.1-908 (West 2008) } \\
10 \text { years for persons not subject to lifetime registration. } \\
\text { Life for persons convicted of any sexually violent offense. }\end{array}$ \\
\hline
\end{tabular}

\section{WASHINGTON**}

Registrable Offenses (Washington)
- $\quad$ Rape in the first degree - WASH. REV. CODE ANN. § 9A.44.040 (West 2008).

- Rape in the second degree - WASH. REV. CODE ANN. § 9A.44.050 (West 2008).

- Rape in the third degree - WASH. REV. CODE ANN. § 9A.44.060 (West 2008).

- Rape of a child in the first degree - WASH. REV. CODE ANN. § 9A.44.073 (West 2008).

- Rape of a child in the second degree - WASH. REV. CODE ANN. § 9A.44.076 (West 2008).

- Rape of a child in the third degree - WASH. REV. CODE ANN. § 9A.44.079 (West 2008).

- Child molestation in the first degree - WASH. REV. CODE ANN. § 9A.44.083 (West 2008).

- Child molestation in the second degree - WASH. REV. CODE ANN. § 9A.44.086 (West 2008).

- Child molestation in the third degree - WASH. REV. CODE ANN. § 9A.44.089 (West 2008).

- Sexual misconduct with a minor in the first degree - WASH. REV. CODE ANN. § 9A.44.093 (West 2008).

- Sexual misconduct with a minor in the second degree - WASH. REV. CODE ANN. § 9A.44.096 (West 2008).

- Indecent liberties - WASH. REV. CODE ANN. § 9A.44.100 (West 2008).

- Sexually violating human remains - WASH. REV. CODE ANN. § 9A.44.105 (West 2008).

- Voyeurism - WASH. REV. CODE ANN. § 9A.44.115 (West 2008).

- Custodial sexual misconduct in the first degree - WASH. REV. CODE ANN. § 9A.44.160 (West 2008).

- Communication with minor for immoral purposes - WASH. REV. CODE ANN. § 9.68A.090 (West 2008).

** Denotes those states where sex offender registration is required for convictions under the staff sexual misconduct laws of the states. Staff and 225 inmates could also be required to register as sex offenders if the offense were charged under other registrable offenses.

This publication is developed by the NIC/WCL Project on Addressing Prison Rape under NIC Cooperative Agreement 06S20GJJ1.

This is not to be posted or reproduced without permission from the authors.

American University, Washington College of Law

Current as of August 2009 


\section{Fifty State Survey of Adult Sex Offender Registration Requirements}

\section{NIC/WCL Project on Addressing Prison Rape}

\begin{tabular}{|c|c|}
\hline $\begin{array}{l}\text { Registrable Offenses Cont'd } \\
\text { (Washington) }\end{array}$ & $\begin{array}{l}\text { - Kidnapping in the first degree - WASH. REV. CODE ANN. §9A.40.020 (West 2008). } \\
\text { - Kidnapping in the second degree - WASH. REV. CODE ANN. §9A.40.030 (West 2008). } \\
\text { - Unlawful imprisonment (where the victim is a minor and the offender is not the minor's parent) - WASH. } \\
\text { - } \text { A criminal attempt, criminal solicitation, or criminal conspiracy to commit an offense that is classified as a } \\
\text { sex offense. } \\
\text { - Any federal or out-of-state conviction for an offense that under the laws of this state would be classified as } \\
\text { - a sex offense under this subsection. } \\
\text { Any gross misdemeanor that is a criminal attempt, solicitation, or conspiracy to commit a sex offense. }\end{array}$ \\
\hline $\begin{array}{l}\text { Sex Offender Registration } \\
\text { Required for Staff Sexual } \\
\text { Misconduct? } \\
\text { (Washington) }\end{array}$ & $\begin{array}{l}\text { YES } \\
\text { WA. ST. § 9A.44.160 (West 2008) } \\
\text { (1) A person is guilty of custodial sexual misconduct in the first degree when the person has sexual intercourse with } \\
\text { another person: } \\
\text { (a) When: } \\
\text { (i) The victim is a resident of a state, county, or city adult or juvenile correctional facility, including but not } \\
\text { limited to jails, prisons, detention centers, or work release facilities, or is under correctional supervision; } \\
\text { and } \\
\text { (ii) The perpetrator is an employee or contract personnel of a correctional agency and the perpetrator has, or } \\
\text { the victim reasonably believes the perpetrator has, the ability to influence the terms, conditions, length, or } \\
\text { fact of incarceration or correctional supervision; or } \\
\text { (b) When the victim is being detained, under arrest[,] or in the custody of a law enforcement officer and the } \\
\text { perpetrator is a law enforcement officer. } \\
\text { (2) Consent of the victim is not a defense to a prosecution under this section. } \\
\text { (3) Custodial sexual misconduct in the first degree is a class C felony. }\end{array}$ \\
\hline
\end{tabular}

** Denotes those states where sex offender registration is required for convictions under the staff sexual misconduct laws of the states. Staff and 226 inmates could also be required to register as sex offenders if the offense were charged under other registrable offenses.

This publication is developed by the NIC/WCL Project on Addressing Prison Rape under NIC Cooperative Agreement 06S20GJJ1.

This is not to be posted or reproduced without permission from the authors.

American University, Washington College of Law

Current as of August 2009 


\section{Fifty State Survey of Adult Sex Offender Registration Requirements}

\section{NIC/WCL Project on Addressing Prison Rape}

\begin{tabular}{|c|c|}
\hline $\begin{array}{l}\text { Information Maintained in } \\
\text { Sex Offender Registry } \\
\text { (Washington) }\end{array}$ & $\begin{array}{l}\text { WA. ST. § 9A.44. } 130 \text { (West 2008) } \\
\text { (3) } \\
\text { (a) The person shall provide the following information when registering: (i) Name; (ii) complete residential } \\
\text { address; (iii) date and place of birth; (iv) place of employment; (v) crime for which convicted; (vi) date and place of } \\
\text { conviction; (vii) aliases used; (viii) social security number; (ix) photograph; and (x) fingerprints. } \\
\text { (b) Any person who lacks a fixed residence shall provide the following information when registering: (i) } \\
\text { Name; (ii) date and place of birth; (iii) place of employment; (iv) crime for which convicted; (v) date and place of } \\
\text { conviction; (vi) aliases used; (vii) social security number; (viii) photograph; (ix) fingerprints; and (x) where he or } \\
\text { she plans to stay. }\end{array}$ \\
\hline $\begin{array}{l}\text { Community Notification } \\
\text { and Websites } \\
\text { (Washington) }\end{array}$ & $\begin{array}{l}\text { WA. ST. } § 4.24 .550 \text { (West 2008) } \\
\text { (1) Public agencies are authorized to release information to the public regarding sex offenders and kidnapping } \\
\text { offenders when the agency determines that disclosure of the information is relevant and necessary to protect the } \\
\text { public and counteract the danger created by the particular offender. } \\
\text { (5) (a) When funded by federal grants or other sources, the Washington association of sheriffs and police chiefs } \\
\text { shall create and maintain a statewide registered kidnapping and sex offender web site, which shall be available to } \\
\text { the public. The web site shall post all level III and level II registered sex offenders and all registered kidnapping } \\
\text { offenders in the state of Washington. }\end{array}$ \\
\hline $\begin{array}{l}\text { Limitations on Residency or } \\
\text { Employment } \\
\text { (Washington) }\end{array}$ & None. \\
\hline $\begin{array}{l}\text { Duration of Registration } \\
\text { (Washington) }\end{array}$ & $\begin{array}{l}\text { WA. ST. § 9A.44.140 (West 2008) } \\
\text { (5)(b) }\end{array}$ \\
\hline
\end{tabular}

** Denotes those states where sex offender registration is required for convictions under the staff sexual misconduct laws of the states. Staff and inmates could also be required to register as sex offenders if the offense were charged under other registrable offenses.

This publication is developed by the NIC/WCL Project on Addressing Prison Rape under NIC Cooperative Agreement 06S20GJJ1.

This is not to be posted or reproduced without permission from the authors.

American University, Washington College of Law

Current as of August 2009 


\section{Fifty State Survey of Adult Sex Offender Registration Requirements}

\section{NIC/WCL Project on Addressing Prison Rape}

\begin{tabular}{|c|c|}
\hline $\begin{array}{l}\text { Duration of Registration } \\
\text { Cont'd } \\
\text { (Washington) }\end{array}$ & $\begin{array}{l}10 \text { years for persons convicted of a class } C \text { felony, but only if they do not have } 1 \text { or more prior sex offense of } \\
\text { kidnapping convictions and have not been convicted of any offense during those } 10 \text { years. } \\
15 \text { years for persons convicted of a class B felony, but only if they do no have } 1 \text { or more prior sex offense or } \\
\text { kidnapping convictions and have not been convicted of any offense during those } 15 \text { years. } \\
\text { A registrant may petition for removal from the registry after } 10 \text { years if: } \\
\text { - They are not a sexually violent predator; } \\
\text { - They were not convicted of a class A sex offense or kidnapping by forcible compulsion; and } \\
\text { - They were not convicted of an aggravated offense or more than } 1 \text { sexually violent offense committed after } \\
\text { March } 12,2002 \text {. } \\
\text { Life for persons: } \\
\text { - Convicted of an aggravated offense after March } 12,2002 \text {; } \\
\text { - Convicted of a sexually violent offense against a minor after March } 12,2002 \text {. }\end{array}$ \\
\hline
\end{tabular}

** Denotes those states where sex offender registration is required for convictions under the staff sexual misconduct laws of the states. Staff and inmates could also be required to register as sex offenders if the offense were charged under other registrable offenses.

This publication is developed by the NIC/WCL Project on Addressing Prison Rape under NIC Cooperative Agreement 06S20GJJ1.

This is not to be posted or reproduced without permission from the authors.

American University, Washington College of Law

Current as of August 2009 


\section{Fifty State Survey of Adult Sex Offender Registration Requirements}

\section{NIC/WCL Project on Addressing Prison Rape}

\begin{tabular}{|c|c|}
\hline $\begin{array}{l}\text { Registrable Offenses Cont'd } \\
\text { (West Virginia) }\end{array}$ & $\begin{array}{l}\text { 2008). } \\
\text { - Distribution and exhibiting of material depicting minors engaged in sexually explicit conduct - W. VA. } \\
\text { CODE ANN. } \S 61-8 C-3 \text { (West 2008). } \\
\text { - Abduction of person; kidnapping or concealing child - W. VA. CODE ANN. } \S 61-2-14 \text { (West 2008). } \\
\text { - Detention of person in place of prostitution - W. VA. CODE ANN. } \S 61-8-6 \text { (West 2008). } \\
\text { - Procuring for house of prostitution - W. VA. CODE ANN. } \S 61-8-7 \text { (West 2008). } \\
\text { - Incest - W. VA. CODE ANN. } \S 61-8-12 \text { (West 2008). } \\
\text { - Any person who has been convicted of a criminal offense and the sentencing judge made a written finding } \\
\text { that the offense was sexually motivated must also register. } \\
\text { Whether or not specifically stated, it is an element of every sexual offense that the sexual act was committed } \\
\text { without the consent of the victim. }\end{array}$ \\
\hline $\begin{array}{l}\text { Sex Offender Registration } \\
\text { Required for Staff Sexual } \\
\text { Misconduct? } \\
\text { (West Virginia) }\end{array}$ & $\begin{array}{l}\text { YES. } \\
\text { W. VA. CODE } \S 61-8 B-10 \\
\text { Imposition of Sexual Intercourse or Sexual Intrusion on Incarcerated Persons. } \\
\text { (a) Any person employed by the Division of Corrections, any person working at a correctional facility managed by } \\
\text { the Commissioner of Corrections pursuant to contract or as an employee of a state agency, any person working at a } \\
\text { correctional facility managed by the Division of Juvenile Services pursuant to contract or as an employee of a state } \\
\text { agency, any person employed by a jail or by the Regional Jail and Correctional Facility Authority, any person } \\
\text { working at a facility managed by the Regional Jail and Correctional Facility Authority or a jail or any person } \\
\text { employed by, or acting pursuant to, the authority of any sheriff, county commission or court to ensure compliance } \\
\text { with the provisions of article eleven-b, chapter sixty-two of this code who engages in sexual intercourse or sexual } \\
\text { intrusion with a person who is incarcerated in this state is guilty of a felony and, upon conviction thereof, shall be } \\
\text { confined in a state correctional facility under the control of the Commissioner of Corrections for not less than one } \\
\text { nor more than five years or fined not more than five thousand dollars. } \\
\text { (b) Any person employed by the Division of Corrections as a parole officer or by the West Virginia Supreme Court }\end{array}$ \\
\hline
\end{tabular}

** Denotes those states where sex offender registration is required for convictions under the staff sexual misconduct laws of the states. Staff and 229 inmates could also be required to register as sex offenders if the offense were charged under other registrable offenses.

This publication is developed by the NIC/WCL Project on Addressing Prison Rape under NIC Cooperative Agreement 06S20GJJ1.

This is not to be posted or reproduced without permission from the authors.

American University, Washington College of Law

Current as of August 2009 


\section{Fifty State Survey of Adult Sex Offender Registration Requirements}

\section{NIC/WCL Project on Addressing Prison Rape}

\begin{tabular}{|c|c|}
\hline $\begin{array}{l}\text { Sex Offender Registration } \\
\text { Required for Staff Sexual } \\
\text { Misconduct? } \\
\text { (West Virginia) }\end{array}$ & $\begin{array}{l}\text { of Appeals as an adult or juvenile probation officer who engages in sexual intercourse or sexual intrusion with a } \\
\text { person said parole officer or probation officer is charged as part of his or her employment with supervising, is guilty } \\
\text { of a felony and, upon conviction thereof, shall be confined in a state correctional facility under the control of the } \\
\text { Commissioner of Corrections for not less than one nor more than five years or fined not more than five thousand } \\
\text { dollars, or both. }\end{array}$ \\
\hline $\begin{array}{l}\text { Information Maintained in } \\
\text { Sex Offender Registry } \\
\text { (West Virginia) }\end{array}$ & $\begin{array}{l}\text { W. VA. CODE } \$ 15-12-2 \text { (West 2008) } \\
\text { (d) (1) The full name of the registrant, including any aliases, nicknames or other names used by the registrant; } \\
\text { (2) The address where the registrant intends to reside or resides at the time of registration, the address of any } \\
\text { habitable real property owned or leased by the registrant that he or she regularly visits: } \\
\text { (3) The registrant's social security number; } \\
\text { (4) A full-face photograph of the registrant at the time of registration; } \\
\text { (5) A brief description of the crime or crimes for which the registrant was convicted; } \\
\text { (6) Fingerprints; } \\
\text { (7) Information related to any motor vehicle, trailer or motor home owned or regularly operated by a registrant, } \\
\text { including vehicle make, model, color and license plate number: } \\
\text { (8) Information relating to any Internet accounts the registrant has and the screen names, user names or aliases } \\
\text { the registrant uses on the internet; and } \\
\text { (9) Information related to any telephone or electronic paging device numbers that the registrant has or uses, } \\
\text { including, but not limited to, residential, work and mobile telephone numbers } \\
\text { (e)(2) } \\
\text { (A) His or her sex; } \\
\text { (B) His or her age at the time of the offense; and } \\
\text { (C) The relationship between the victim and the perpetrator. } \\
\text { (f) For any person determined to be a sexually violent predator, the notice required by subsection (d) of this } \\
\text { section must also include: } \\
\text { (1) Identifying factors, including physical characteristics; }\end{array}$ \\
\hline
\end{tabular}

** Denotes those states where sex offender registration is required for convictions under the staff sexual misconduct laws of the states. Staff and 230 inmates could also be required to register as sex offenders if the offense were charged under other registrable offenses.

This publication is developed by the NIC/WCL Project on Addressing Prison Rape under NIC Cooperative Agreement 06S20GJJ1.

This is not to be posted or reproduced without permission from the authors.

American University, Washington College of Law

Current as of August 2009 


\section{Fifty State Survey of Adult Sex Offender Registration Requirements}

\section{NIC/WCL Project on Addressing Prison Rape}

\begin{tabular}{|c|c|}
\hline $\begin{array}{l}\text { Information Maintained in } \\
\text { Sex Offender Registry } \\
\text { Cont'd } \\
\text { (West Virginia) }\end{array}$ & $\begin{array}{l}\text { (2) History of the offense; and } \\
\text { (3) Documentation of any treatment received for the mental abnormality or personality disorder. }\end{array}$ \\
\hline $\begin{array}{l}\text { Community Notification } \\
\text { and Websites } \\
\text { (West Virginia) }\end{array}$ & $\begin{array}{l}\text { W. VA. CODE } § 15-12-2 \text { (West 2008) } \\
\text { (h) The State Police shall maintain a central registry of all persons who register under this article and shall release } \\
\text { information only as provided in this article. The information required to be made public by the State Police by } \\
\text { subdivision (2), subsection (b), section five of this article is to be accessible through the Internet. No information } \\
\text { relating to telephone or electronic paging device numbers a registrant has or uses may be released through the } \\
\text { Internet. } \\
\text { W. VA. CoDE } § 15-12-5 \text { (West 2008) } \\
\text { (a) Within five business days after receiving any notification as described in this article, the State Police shall } \\
\text { distribute a copy of the notification statement to: } \\
\text { (1) The supervisor of each county and municipal law-enforcement office and any campus police department } \\
\text { in the city and county where the registrant resides, owns or leases habitable real property that he or she } \\
\text { regularly visits, is employed or attends school or a training facility; } \\
\text { (2) The county superintendent of schools in each county where the registrant resides, owns or leases } \\
\text { habitable real property that he or she regularly visits, is employed or attends school or a training facility; } \\
\text { (3) The child protective services office charged with investigating allegations of child abuse or neglect in } \\
\text { the county where the registrant resides, owns or leases habitable real property that he or she regularly visits, } \\
\text { is employed or attends school or a training facility; } \\
\text { (4) All community organizations or religious organizations which regularly provide services to youths in }\end{array}$ \\
\hline
\end{tabular}

** Denotes those states where sex offender registration is required for convictions under the staff sexual misconduct laws of the states. Staff and 231 inmates could also be required to register as sex offenders if the offense were charged under other registrable offenses.

This publication is developed by the NIC/WCL Project on Addressing Prison Rape under NIC Cooperative Agreement 06S20GJJ1.

This is not to be posted or reproduced without permission from the authors.

American University, Washington College of Law

Current as of August 2009 


\section{Fifty State Survey of Adult Sex Offender Registration Requirements}

\section{NIC/WCL Project on Addressing Prison Rape}

\begin{tabular}{|c|c|}
\hline $\begin{array}{l}\text { Community Notification } \\
\text { and Websites Cont'd } \\
\text { (West Virginia) }\end{array}$ & $\begin{array}{l}\text { the county where the registrant resides, owns or leases habitable real property that he or she regularly visits, } \\
\text { is employed or attends school or a training facility; } \\
\text { (5) Individuals and organizations which provide day care services for youths or day care, residential or } \\
\text { respite care, or other supportive services for mentally or physically incapacitated or infirm persons in the } \\
\text { county where the registrant resides, owns or leases habitable real property that he or she regularly visits, is } \\
\text { employed or attends school or a training facility; and } \\
\text { (6) The Federal Bureau of Investigation (FBI). } \\
\text { (b)(2) The State Police shall maintain and make available to the public at least quarterly the list of all persons who } \\
\text { are required to register for life according to the terms of subdivision (2), subsection (a), section four of this article. } \\
\text { No information concerning the identity of a victim of an offense requiring registration or telephone or electronic } \\
\text { paging device numbers a registrant has or uses may be released with this list. The method of publication and access } \\
\text { to this list are to be determined by the superintendent; }\end{array}$ \\
\hline $\begin{array}{l}\text { Limitations on Residency or } \\
\text { Employment } \\
\text { (West Virginia) }\end{array}$ & None. \\
\hline $\begin{array}{l}\text { Duration of Registration } \\
\text { (West Virginia) }\end{array}$ & $\begin{array}{l}\text { W. VA. CODE } § 15-12-4 \text { (West 2008) } \\
\text { (a)(1) } 10 \text { years for persons not subject to lifetime registration. } \\
\text { (a)(2) Life for persons: } \\
\text { - With } 1 \text { or more prior convictions for a registrable offense; } \\
\text { - Convicted of a registrable offense against multiple victims or multiple violations of the same offense; } \\
\text { - That have been deemed sexually violent predators; } \\
\text { - Convicted of a sexually violent offense; or } \\
\text { - Convicted of a registrable offense against a minor. }\end{array}$ \\
\hline
\end{tabular}

** Denotes those states where sex offender registration is required for convictions under the staff sexual misconduct laws of the states. Staff and 232 inmates could also be required to register as sex offenders if the offense were charged under other registrable offenses.

This publication is developed by the NIC/WCL Project on Addressing Prison Rape under NIC Cooperative Agreement 06S20GJJ1.

This is not to be posted or reproduced without permission from the authors.

American University, Washington College of Law

Current as of August 2009 


\section{Fifty State Survey of Adult Sex Offender Registration Requirements}

\section{NIC/WCL Project on Addressing Prison Rape}

\section{WISCONSIN**}

Registrable Offenses

(Wisconsin)
- $\quad$ Sexual exploitation by therapist - WIS. STAT. ANN. § 940.22(2) (West West 2008).

- Sexual assault (1st, 2nd, and 3rd degree) - WIS. STAT. ANN. § 940.225(1), (2), or (3) (West West 2008).

- Incest - WIS. STAT. ANN. §944.06 (West West 2008).

- Sexual assault of a child (1st and 2nd degree) - WIS. STAT. ANN. §948.02 (West West 2008).

- Engaging in repeated acts of sexual assault of the same child - WIS. STAT. ANN. $\$ 948.025$ (West West 2008).

- Sexual exploitation of a child - WIS. STAT. ANN. § 948.05 (West West 2008).

- Causing a child to view or listen to sexual activity - WIS. STAT. ANN. $\$ 948.055$ (West West 2008).

- Incest with a child - WIS. STAT. ANN. $\$ 948.06$ (West West 2008).

- Child enticement - WIS. STAT. ANN. §948.07 (West West 2008).

- Use of a computer to facilitate a child sex crime - WIS. STAT. ANN. § 948.075 (West West 2008).

- Soliciting a child for prostitution - WIS. STAT. ANN. §948.08 (West West 2008).

- Sexual assault of a student by a school instructional staff person - WIS. STAT. ANN. § 948.095 (West West 2008).

- Exposing a child to harmful material or harmful descriptions or narrations - WIS. STAT. ANN. § 948.11(2)(a) or (am) (West West 2008).

- Possession of child pornography - WIS. STAT. ANN. § 948.12 (West West 2008).

- Child sex offender working with children - WIS. STAT. ANN. § 948.13 (West West 2008).

- Abduction of another's child - WIS. STAT. ANN. §948.30 (West West 2008).

- False imprisonment (if the victim was a minor and the actor is not a parent of the victim) - WIS. STAT. ANN. § 940.30 (West West 2008).

- Kidnapping (if the victim was a minor and the actor is not a parent of the victim) - WIS. STAT. ANN. § 940.31 (West West 2008).

- The attempt, solicitation, or conspiracy to commit any of the listed offenses.

- Persons found to have committed a sex offense in another jurisdiction, including:

inmates could also be required to register as sex offenders if the offense were charged under other registrable offenses. 


\section{Fifty State Survey of Adult Sex Offender Registration Requirements}

\section{NIC/WCL Project on Addressing Prison Rape}

\begin{tabular}{|c|c|}
\hline $\begin{array}{l}\text { Registrable Offenses Cont'd } \\
\text { (Wisconsin) }\end{array}$ & $\begin{array}{l}\text { O Convicted or found not guilty or not responsible by reason of mental disease or defect for a } \\
\text { violation of a law of another state that is comparable to a sex offense. } \\
\text { O Convicted or found not guilty by reason of mental disease or defect for a violation of a federal law } \\
\text { that is comparable to a sex offense. } \\
\text { o Convicted or found not guilty or not responsible by reason of mental disease or defect in the tribal } \\
\text { court of a federally recognized American Indian tribe or band for a violation that is comparable to a } \\
\text { sex offense. } \\
\text { o Sentenced or found not guilty by reason of mental disease or defect by a court martial for a } \\
\text { violation that is comparable to a sex offense. } \\
\text { O Persons residing in Wisconsin or carrying on a vocation in Wisconsin who have previously been } \\
\text { registered as sex offenders in another state or with the FBI pursuant to } 42 \text { USCS } \S 14072 \text {. }\end{array}$ \\
\hline $\begin{array}{l}\text { Sex Offender Registration } \\
\text { Required for Staff Sexual } \\
\text { Misconduct? } \\
\text { (Wisconsin) }\end{array}$ & $\begin{array}{l}\text { YES } \\
\text { W.S.A. } \$ 940.225 \text { (West 2008) } \\
\text { Second degree sexual assault. } \\
\text { (h) Has sexual contact or sexual intercourse with an individual who is confined in a correctional institution } \\
\text { if the actor is a correctional staff member. This paragraph does not apply if the individual with whom the } \\
\quad \begin{array}{l}\text { actor has sexual contact or sexual intercourse is subject to prosecution for the sexual contact or sexual } \\
\text { intercourse under this section. }\end{array}\end{array}$ \\
\hline $\begin{array}{l}\text { Information Maintained in } \\
\text { Sex Offender Registry } \\
\text { (Wisconsin) }\end{array}$ & $\begin{array}{l}\text { W.S.A. } \S 301.46 \text { (West 2008) } \\
\text { (b) The department shall make all of the following information available under par. } \\
\text { (a): } \\
\text { 1. The person's name, including any aliases used by the person. } \\
\text { 2. Information sufficient to identify the person, including date of birth, gender, race, height, weight } \\
\text { and hair and eye color. } \\
\text { 3. The statute the person violated, the date of conviction, adjudication or commitment, and the county }\end{array}$ \\
\hline
\end{tabular}

** Denotes those states where sex offender registration is required for convictions under the staff sexual misconduct laws of the states. Staff and 234 inmates could also be required to register as sex offenders if the offense were charged under other registrable offenses.

This publication is developed by the NIC/WCL Project on Addressing Prison Rape under NIC Cooperative Agreement 06S20GJJ1.

This is not to be posted or reproduced without permission from the authors.

American University, Washington College of Law

Current as of August 2009 


\section{Fifty State Survey of Adult Sex Offender Registration Requirements}

\section{NIC/WCL Project on Addressing Prison Rape}

\begin{tabular}{|c|c|}
\hline $\begin{array}{l}\text { Information Maintained in } \\
\text { Sex Offender Registry } \\
\text { Cont'd } \\
\text { (Wisconsin) }\end{array}$ & $\begin{array}{l}\text { or, if the state is not this state, the state in which the person was convicted, adjudicated or } \\
\text { committed. } \\
\text { 4. Whichever of the following is applicable: } \\
\text { a. The date the person was placed on probation, supervision, conditional release, conditional } \\
\text { transfer or supervised release. } \\
\text { b. The date the person was released from confinement, whether on parole, extended supervision or } \\
\text { otherwise, or discharged or terminated from a sentence or commitment. } \\
\text { d. The date the person entered the state. } \\
\text { 5. The date the person was ordered to comply with s. } 301.45 \text {. } \\
\text { 6. The name of the agency supervising the person, if applicable, and the office or unit and telephone } \\
\text { number of the office or unit that is responsible for the supervision of the person. } \\
\text { 7. The name and address of the place at which the person is employed. } \\
\text { 8. The name and location of any school in which the person is enrolled. } \\
\text { 9. The most recent date on which the information under s. } 301.45 \text { was updated. }\end{array}$ \\
\hline $\begin{array}{l}\text { Community Notification } \\
\text { and Websites } \\
\text { (Wisconsin) }\end{array}$ & $\begin{array}{l}\text { W.S.A. } \$ 301.46 \text { (West 2008). } \\
\text { (2)(a) When a person is registered with the department, the department shall immediately make the information } \\
\text { available to the police chief of any community and the sheriff of any county in which the person is residing, is } \\
\text { employed or is attending school. } \\
\text { (e) A police chief or sheriff may provide any of the information to which he or she has access under this subsection } \\
\text { to an entity in the police chief's community or the sheriff's county that is entitled to request information, to any } \\
\text { person requesting information or to members of the general public if, in the opinion of the police chief or sheriff, } \\
\text { providing that information is necessary to protect the public. } \\
\text { (5)(a) The department or a police chief or sheriff may provide information concerning a specific person required to } \\
\text { register to a person who is not provided notice or access to information, if in the opinion of the department or the } \\
\text { police chief or sheriff, providing the information is necessary to protect the public. }\end{array}$ \\
\hline
\end{tabular}

** Denotes those states where sex offender registration is required for convictions under the staff sexual misconduct laws of the states. Staff and 235 inmates could also be required to register as sex offenders if the offense were charged under other registrable offenses.

This publication is developed by the NIC/WCL Project on Addressing Prison Rape under NIC Cooperative Agreement 06S20GJJ1.

This is not to be posted or reproduced without permission from the authors.

American University, Washington College of Law

Current as of August 2009 


\section{Fifty State Survey of Adult Sex Offender Registration Requirements}

\section{NIC/WCL Project on Addressing Prison Rape}

\begin{tabular}{|c|c|}
\hline $\begin{array}{l}\text { Community Notification } \\
\text { and Websites Cont'd } \\
\text { (Wisconsin) }\end{array}$ & $\begin{array}{l}\text { ( } 5 \mathrm{n} \text { )(a) No later than June 1,2001, the department shall provide access to information concerning persons registered } \\
\text { by creating and maintaining an Internet site and by any other means that the department determines is appropriate. }\end{array}$ \\
\hline $\begin{array}{l}\text { Duration of Registration } \\
\text { (Wisconsin) }\end{array}$ & $\begin{array}{l}\text { W.S.A. } \S 301.45 \text { (West 2008) } \\
\text { (5) } 15 \text { years for persons not subject to lifetime registration. } \\
\text { Life for persons: } \\
\text { - With } 2 \text { or more sex offense convictions, occurring on separate occasions; } \\
\text { - Convicted of First or Second degree sexual assault; } \\
\text { - Convicted of First or Second degree child sexual assault; } \\
\text { - Found to be a sexually violent person; or } \\
\text { - Subject to lifetime supervision. }\end{array}$ \\
\hline $\begin{array}{l}\text { Registrable Offenses } \\
\text { (Wyoming) }\end{array}$ & $\begin{array}{ll} & \text { Sexual assault (1st degree) - WYO. STAT. ANN. § 6-2-302 (West 2008). } \\
\text { - } & \text { Sexual assault (2nd degree) - WYO. STAT. ANN. § 6-2-303 (West 2008). } \\
\text { - } & \text { Sexual assault (3rd degree) - WYO. STAT. ANN. § 6-2-304(a)(i) or (a)(ii) (West 2008). } \\
\text { - } & \text { Sexual assault (3rd degree), if the victim is under 16 - WYO. STAT. ANN. § 6-2-304(a)(iii) (West 2008). } \\
\text { - } & \text { Incest - WYO. STAT. ANN. § 6-4-402 (West 2008). } \\
\text { - } & \text { Immoral or indecent acts, when the victim is under the age of } 16 \text { and the offender was at least four (4) years } \\
& \text { older than the victim - WYO. STAT. ANN. } § 14-3-105 \text { (West 2008). }\end{array}$ \\
\hline
\end{tabular}

** Denotes those states where sex offender registration is required for convictions under the staff sexual misconduct laws of the states. Staff and 236 inmates could also be required to register as sex offenders if the offense were charged under other registrable offenses.

This publication is developed by the NIC/WCL Project on Addressing Prison Rape under NIC Cooperative Agreement 06S20GJJ1.

This is not to be posted or reproduced without permission from the authors.

American University, Washington College of Law

Current as of August 2009 


\section{Fifty State Survey of Adult Sex Offender Registration Requirements}

\section{NIC/WCL Project on Addressing Prison Rape}

\begin{tabular}{|c|c|}
\hline $\begin{array}{l}\text { Registrable Offenses Cont'd } \\
\text { (Wyoming) }\end{array}$ & 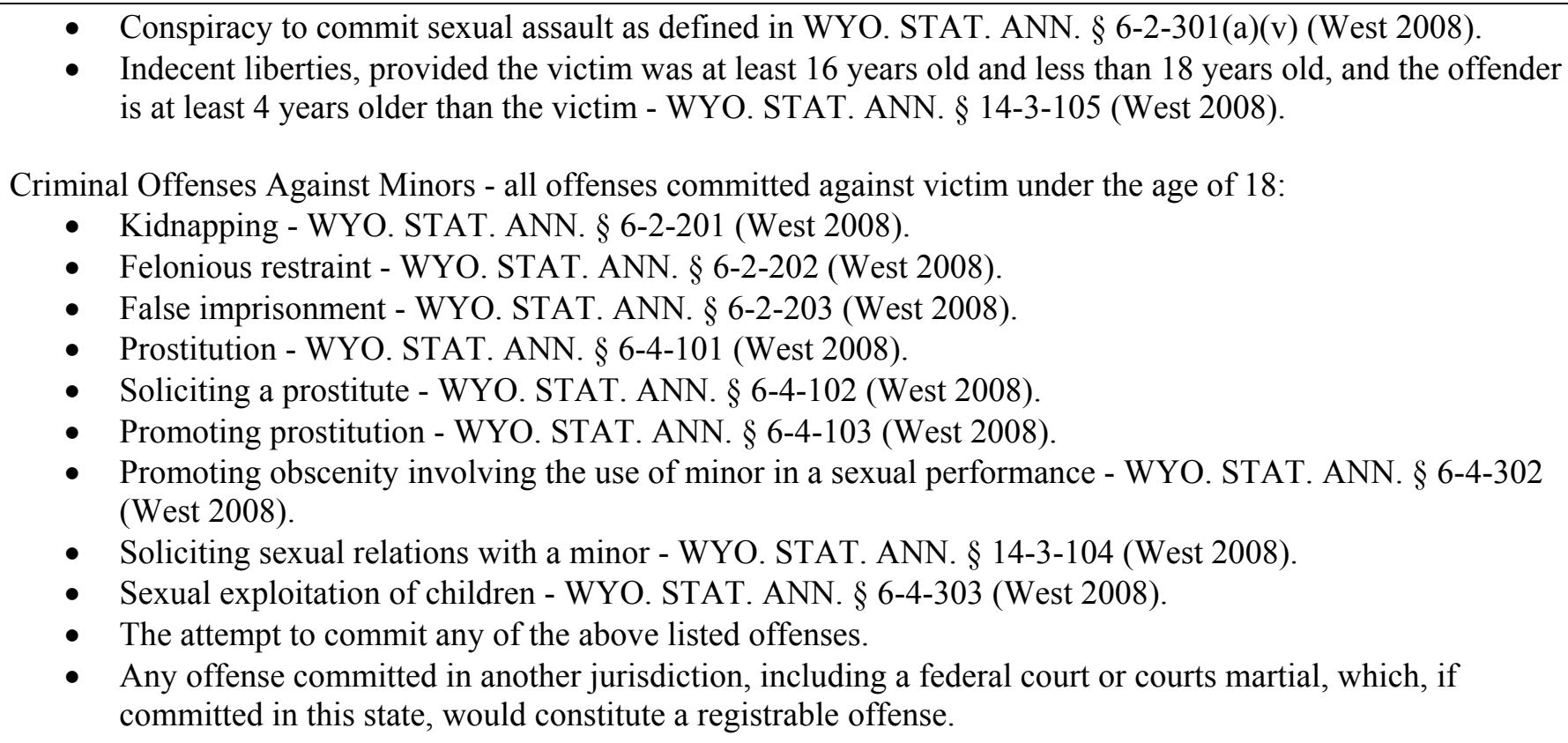 \\
\hline & $\begin{array}{l}\text { (a) Any actor who inflicts sexual intrusion on a victim commits sexual assault in the second degree if, under } \\
\text { circumstances not constituting sexual assault in the first degree: }\end{array}$ \\
\hline
\end{tabular}

** Denotes those states where sex offender registration is required for convictions under the staff sexual misconduct laws of the states. Staff and inmates could also be required to register as sex offenders if the offense were charged under other registrable offenses.

This publication is developed by the NIC/WCL Project on Addressing Prison Rape under NIC Cooperative Agreement 06S20GJJ1.

This is not to be posted or reproduced without permission from the authors.

American University, Washington College of Law

Current as of August 2009 


\section{Fifty State Survey of Adult Sex Offender Registration Requirements}

\section{NIC/WCL Project on Addressing Prison Rape}

\begin{tabular}{|c|c|}
\hline $\begin{array}{l}\text { Sex Offender Registration } \\
\text { Required for Staff Sexual } \\
\text { Misconduct? Cont'd } \\
\text { (Wyoming) }\end{array}$ & $\begin{array}{l}\text { victim to submit; } \\
\text { (vii) The actor is an employee, independent contractor or volunteer of a state, county, city or town, or } \\
\text { privately operated adult or juvenile correctional system, including but not limited to jails, penal institutions, } \\
\text { detention centers, juvenile residential or rehabilitative facilities, adult community correctional facilities, } \\
\text { secure treatment facilities or work release facilities, and the victim is known or should be known by the } \\
\text { actor to be a resident of such facility or under supervision of the correctional system; or } \\
\text { (viii) The actor inflicts sexual intrusion in treatment or examination of a victim for purposes or in a manner } \\
\text { substantially inconsistent with reasonable medical practices. } \\
\text { (b) A person is guilty of sexual assault in the second degree if he subjects another person to sexual contact and } \\
\text { causes serious bodily injury to the victim under any of the circumstances listed in W.S. 6-2-302(a)(i) through (iv) or } \\
\text { paragraphs (a)(i) through (vii) of this section. }\end{array}$ \\
\hline $\begin{array}{l}\text { Information Maintained in } \\
\text { Sex Offender Registry } \\
\text { (Wyoming) }\end{array}$ & $\begin{array}{l}\text { W.S. } 1977 \S 7-19-302 \text { (West 2008) } \\
\text { (a) Any offender residing in this state or entering this state for the purpose of residing in this state shall register with } \\
\text { the division of criminal investigation or other entity in accordance with the provisions of this act. The offender shall } \\
\text { be photographed, fingerprinted and palmprinted by the registering entity or another law enforcement agency and } \\
\text { shall provide the following additional information when registering: } \\
\text { (i) Name, including any aliases ever used; } \\
\text { (ii) Address; } \\
\text { (iii) Date and place of birth; } \\
\text { (iv) Social security number; } \\
\text { (v) Place of employment; } \\
\text { (vi) Date and place of conviction; } \\
\text { (vii) Crime for which convicted; } \\
\text { (viii) The name and location of each educational institution in this state at which the person is employed or } \\
\text { attending school; }\end{array}$ \\
\hline
\end{tabular}

** Denotes those states where sex offender registration is required for convictions under the staff sexual misconduct laws of the states. Staff and 238 inmates could also be required to register as sex offenders if the offense were charged under other registrable offenses.

This publication is developed by the NIC/WCL Project on Addressing Prison Rape under NIC Cooperative Agreement 06S20GJJ1.

This is not to be posted or reproduced without permission from the authors.

American University, Washington College of Law

Current as of August 2009 


\section{Fifty State Survey of Adult Sex Offender Registration Requirements}

\section{NIC/WCL Project on Addressing Prison Rape}

\begin{tabular}{|c|c|}
\hline $\begin{array}{l}\text { Information Maintained in } \\
\text { Sex Offender Registry } \\
\text { (Wyoming) }\end{array}$ & $\begin{array}{l}\text { (ix) The license plate number and a description of any vehicle owned or operated by the offender; and } \\
\text { (x) A DNA sample. As used in this paragraph, "DNA" means as defined in W.S. 7-19-401(a)(vi). }\end{array}$ \\
\hline $\begin{array}{l}\text { Community Notification } \\
\text { and Websites } \\
\text { (Wyoming) }\end{array}$ & $\begin{array}{l}\text { W.S. } 1977 \S 7-19-303 \text { (West 2008) } \\
\text { (c)The district court shall make a finding by a preponderance of the evidence of the risk of reoffense by the } \\
\text { offender, and based on that finding authorize the county sheriff, police chief or their designee to release information } \\
\text { regarding an offender who has been convicted of an offense that requires registration under this act, as follows: } \\
\text { (i) If the risk of reoffense is low, notification shall be in accordance with the requirements of W.S. 7-19-106 to } \\
\text { persons authorized to receive criminal history record information under W.S. 7-19-106; } \\
\text { (ii) If the risk of reoffense is moderate, notification shall be provided to residential neighbors within at least } \\
\text { seven hundred fifty (750) feet of the offender's residence, organizations in the community, including schools, } \\
\text { religious and youth organizations, as well as to the persons authorized under paragraph (i) of this subsection, } \\
\text { through means specified in the court's order. In addition, notification regarding an offender employed by or } \\
\text { attending school at any educational institution shall be provided upon request to a member of the institution's } \\
\text { campus community; } \\
\text { (iii) If the risk of reoffense is high, notification shall be provided to the public through a public registry and } \\
\text { through any additional means specified in the court's order, as well as to the persons and entities required by } \\
\text { paragraphs (i) and (ii) of this subsection. } \\
\text { - The division shall make the public registry available to the public through electronic internet technology. }\end{array}$ \\
\hline $\begin{array}{l}\text { Limitations on Residency or } \\
\text { Employment } \\
\text { (Wyoming) }\end{array}$ & None. \\
\hline $\begin{array}{l}\text { Duration of A Registration } \\
\text { (Wyoming) }\end{array}$ & $\begin{array}{l}\text { W.S. } 1977 \S 7-19-304 \text { (West 2008) } \\
10 \text { years for persons not subject to lifetime registration. } \\
\text { Life for aggravated sex offenders and recidivists. }\end{array}$ \\
\hline
\end{tabular}

** Denotes those states where sex offender registration is required for convictions under the staff sexual misconduct laws of the states. Staff and inmates could also be required to register as sex offenders if the offense were charged under other registrable offenses.

This publication is developed by the NIC/WCL Project on Addressing Prison Rape under NIC Cooperative Agreement 06S20GJJ1.

This is not to be posted or reproduced without permission from the authors.

American University, Washington College of Law

Current as of August 2009 


\section{Fifty State Survey of Adult Sex Offender Registration Requirements}

\section{NIC/WCL Project on Addressing Prison Rape}

\begin{tabular}{|c|c|}
\hline \multicolumn{2}{|r|}{ UNITED STATES** } \\
\hline $\begin{array}{l}\text { Registrable Offenses } \\
\text { (U.S. Federal Law) }\end{array}$ & $\begin{array}{l}\text { - Sex trafficking committed against a minor. } 18 \text { U.S.C. } \S 1591 \text { (West 2008). } \\
\text { - } \quad \text { Coercion and enticement committed against a minor. } 18 \text { U.S.C. } \S 2422 \text { (b) (West 2008). } \\
\text { - Transportation with intent to engage in criminal sexual activity committed against a minor. } 18 \text { U.S.C. } \S \\
\text { - } 2423(\text { a) (West } 2008 \text { ). } \\
\text { - Agusive sexual contact committed against a minor. } 18 \text { U.S.C. } \S 2244 \text { (West 2008). } \\
\text { - Abgravated sexual abuse or sexual abuse. } 18 \text { U.S.C. } \S \S 2241 \text { and } 2242 \text { (West 2008). } \\
2244 \text { (West 2008). }\end{array}$ \\
\hline $\begin{array}{l}\text { Sex Offender Registration } \\
\text { Required for Staff Sexual } \\
\text { Misconduct? } \\
\text { (U.S. Federal Law) }\end{array}$ & $\begin{array}{l}\text { YES. } \\
18 \text { U.S.C.S. } \$ 2242 \text { (West 2008) } \\
\text { Aggravated Sexual Abuse } \\
\text { (a) By force or threat.--Whoever, in the special maritime and territorial jurisdiction of the United States or in a } \\
\text { Federal prison, or in any prison, institution, or facility in which persons are held in custody by direction of or } \\
\text { pursuant to a contract or agreement with the head of any Federal department or agency, knowingly causes another } \\
\text { person to engage in a sexual act-- } \\
\quad \text { (1) by using force against that other person; or } \\
\quad \text { (2) by threatening or placing that other person in fear that any person will be subjected to death, serious } \\
\text { bodily injury, or kidnapping; } \\
18 \text { U.S.C.S. } \S 2241 \text { \& } 2242 \text { (West 2008) } \\
\text { Sexual Abuse } \\
\text { Whoever, in the special maritime and territorial jurisdiction of the United States or in a Federal prison, or in any }\end{array}$ \\
\hline
\end{tabular}

** Denotes those states where sex offender registration is required for convictions under the staff sexual misconduct laws of the states. Staff and inmates could also be required to register as sex offenders if the offense were charged under other registrable offenses.

This publication is developed by the NIC/WCL Project on Addressing Prison Rape under NIC Cooperative Agreement 06S20GJJ1.

This is not to be posted or reproduced without permission from the authors.

American University, Washington College of Law

Current as of August 2009 


\section{Fifty State Survey of Adult Sex Offender Registration Requirements}

\section{NIC/WCL Project on Addressing Prison Rape}

\begin{tabular}{|c|c|}
\hline $\begin{array}{l}\text { Sex Offender Registration } \\
\text { Required for Staff Sexual } \\
\text { Misconduct? Cont'd } \\
\text { (U.S. Federal Law) }\end{array}$ & 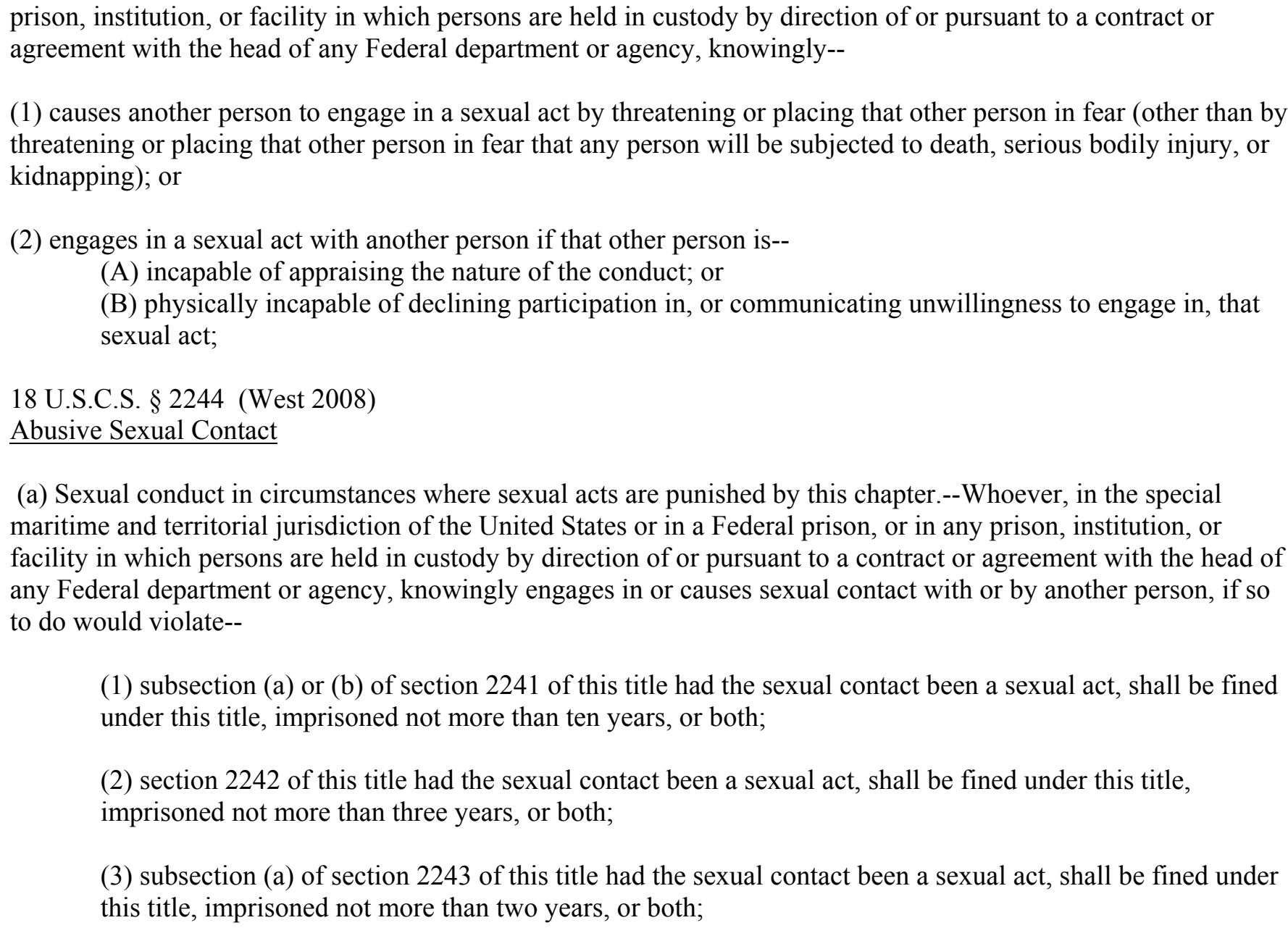 \\
\hline
\end{tabular}

** Denotes those states where sex offender registration is required for convictions under the staff sexual misconduct laws of the states. Staff and inmates could also be required to register as sex offenders if the offense were charged under other registrable offenses.

This publication is developed by the NIC/WCL Project on Addressing Prison Rape under NIC Cooperative Agreement 06S20GJJ1.

This is not to be posted or reproduced without permission from the authors.

American University, Washington College of Law

Current as of August 2009 


\section{Fifty State Survey of Adult Sex Offender Registration Requirements}

\section{NIC/WCL Project on Addressing Prison Rape}

\begin{tabular}{|c|c|}
\hline $\begin{array}{l}\text { Sex Offender Registration } \\
\text { Required for Staff Sexual } \\
\text { Misconduct? Cont'd } \\
(\text { U.S. Federal Law) }\end{array}$ & $\begin{array}{l}\text { (4) subsection (b) of section } 2243 \text { of this title had the sexual contact been a sexual act, shall be fined under } \\
\text { this title, imprisoned not more than two years, or both; or } \\
\text { (5) subsection (c) of section } 2241 \text { of this title had the sexual contact been a sexual act, shall be fined under } \\
\text { this title and imprisoned for any term of years or for life. }\end{array}$ \\
\hline $\begin{array}{l}\text { Information Maintained in } \\
\text { Sex Offender Registry } \\
\text { (U.S. Federal Law) }\end{array}$ & $\begin{array}{l}42 \text { U.S.C.S. } \S 16914 \text { (West 2008) } \\
\text { (a) Provided by the offender. The sex offender shall provide the following information to the appropriate official for } \\
\text { inclusion in the sex offender registry: } \\
\text { (1) The name of the sex offender (including any alias used by the individual). } \\
\text { (2) The Social Security number of the sex offender. } \\
\text { (3) The address of each residence at which the sex offender resides or will reside. } \\
\text { (4) The name and address of any place where the sex offender is an employee or will be an employee. } \\
\text { (5) The name and address of any place where the sex offender is a student or will be a student. } \\
\text { (6) The license plate number and a description of any vehicle owned or operated by the sex offender. } \\
\text { (7) Any other information required by the Attorney General. } \\
\text { (b) Provided by the jurisdiction. The jurisdiction in which the sex offender registers shall ensure that the following } \\
\text { information is included in the registry for that sex offender: } \\
\text { (1) A physical description of the sex offender. } \\
\text { (2) The text of the provision of law defining the criminal offense for which the sex offender is registered. } \\
\text { (3) The criminal history of the sex offender, including the date of all arrests and convictions; the status of } \\
\text { parole, probation, or supervised release; registration status; and the existence of any outstanding arrest } \\
\text { warrants for the sex offender. } \\
\text { (4) A current photograph of the sex offender. } \\
\text { (5) A set of fingerprints and palm prints of the sex offender. } \\
\text { (6) A DNA sample of the sex offender. }\end{array}$ \\
\hline
\end{tabular}

** Denotes those states where sex offender registration is required for convictions under the staff sexual misconduct laws of the states. Staff and inmates could also be required to register as sex offenders if the offense were charged under other registrable offenses.

This publication is developed by the NIC/WCL Project on Addressing Prison Rape under NIC Cooperative Agreement 06S20GJJ1.

This is not to be posted or reproduced without permission from the authors.

American University, Washington College of Law

Current as of August 2009 


\section{Fifty State Survey of Adult Sex Offender Registration Requirements}

\section{NIC/WCL Project on Addressing Prison Rape}

\begin{tabular}{|c|c|}
\hline $\begin{array}{l}\text { Information Maintained in } \\
\text { Sex Offender Registry } \\
\text { Cont'd } \\
\text { (U.S. Federal Law) }\end{array}$ & $\begin{array}{l}\text { (7) A photocopy of a valid driver's license or identification card issued to the sex offender by a jurisdiction. } \\
\text { (8) Any other information required by the Attorney General. }\end{array}$ \\
\hline $\begin{array}{l}\text { Community Notification } \\
\text { and Websites } \\
\text { (U.S. Federal Law) }\end{array}$ & $\begin{array}{l}42 \text { U.S.C.S. } \$ 16918 \text { (West 2008). } \\
\text { (a): } \\
\text { - Each jurisdiction shall make available on the Internet, in a manner that is readily accessible to all jurisdictions } \\
\text { and to the public, all information about each sex offender in the registry. } \\
\text { - The jurisdiction shall maintain the Internet site in a manner that will permit the public to obtain relevant } \\
\text { information for each sex offender by a single query for any given zip code or geographic radius set by the user. } \\
42 \text { U.S.C.S. } \S 16919 \text { (West 2008). } \\
\text { (a): } \\
\text { - The Attorney General shall maintain a national database at the Federal Bureau of Investigation for each sex } \\
\text { offender and any other person required to register in a jurisdiction's sex offender registry. } \\
\text { - The database shall be known as the National Sex Offender Registry. }\end{array}$ \\
\hline $\begin{array}{l}\text { Limitations on Residency or } \\
\text { Employment } \\
\text { (U.S. Federal Law) }\end{array}$ & None \\
\hline $\begin{array}{l}\text { Duration of Registration } \\
\text { (U.S. Federal Law) }\end{array}$ & $\begin{array}{l}42 \text { U.S.C.S. } § 16915 \text { (West 2008). } \\
15 \text { years for Tier I sex offender. }\end{array}$ \\
\hline
\end{tabular}

** Denotes those states where sex offender registration is required for convictions under the staff sexual misconduct laws of the states. Staff and 243 inmates could also be required to register as sex offenders if the offense were charged under other registrable offenses.

This publication is developed by the NIC/WCL Project on Addressing Prison Rape under NIC Cooperative Agreement 06S20GJJ1.

This is not to be posted or reproduced without permission from the authors.

American University, Washington College of Law

Current as of August 2009 


\section{Fifty State Survey of Adult Sex Offender Registration Requirements}

\section{NIC/WCL Project on Addressing Prison Rape}

\begin{tabular}{|l|l|}
\hline $\begin{array}{l}\text { Duration of Registration } \\
\text { Cont'd } \\
\text { (U.S. Federal Law) }\end{array}$ & $\begin{array}{l}25 \text { years for Tier II sex offenders. } \\
\text { Life for Tier III sex offenders. } \\
\text { The registration period may be reduced if the offender maintains a "clean record" pursuant to the requirements of } \\
42 \text { U.S.C. } \S 16915(\mathrm{~b}) \text { (West 2008). }\end{array}$ \\
\hline
\end{tabular}

\footnotetext{
${ }^{1}$ Guam does not currently have a specific state criminal law prohibiting the sexual abuse of individuals under custodial supervision. However the federal criminal law prohibiting the sexual abuse of individuals under custodial supervision would apply in certain areas within the state as would the sex offender registration stipulations.

${ }^{2}$ Kentucky recently amended its sex offender registration law. This information will be modified when these changes are codified.

${ }^{3}$ Legislation is pending to amend N.H. REV. STAT. ANN. $\$ 649-A: 32007$ NH S.B. 495 (NS)

${ }^{4}$ The Virgin Islands does not currently have a specific state criminal law prohibiting the sexual abuse of individuals under custodial supervision. However the federal criminal law prohibiting the sexual abuse of individuals under custodial supervision would apply in certain areas within the state as would the sex offender registration stipulations.
} inmates could also be required to register as sex offenders if the offense were charged under other registrable offenses.

This publication is developed by the NIC/WCL Project on Addressing Prison Rape under NIC Cooperative Agreement 06S20GJJ1.

This is not to be posted or reproduced without permission from the authors.

American University, Washington College of Law

Current as of August 2009 